\title{
SOBREVALORIZAÇÃO DA TAXA DE CÂMBIO E O AGRONEGÓCIO: UMA ANÁLISE DE EQUILÍBRIO GERAL COM BASE NA ESTRUTURA PRODUTIVA BRASILEIRA DE 1995
}

\author{
João Carlos Vianna de Oliveira
}

Tese apresentada à Escola Superior de Agricultura "Luiz de Queiroz", Universidade de São Paulo, para obtenção do título de Doutor em Ciências, Área de Concentração: Economia Aplicada.

PIRACICABA

Estado de São Paulo - Brasil

Janeiro - 2002 


\title{
SOBREVALORIZAÇÃO DA TAXA DE CÂMBIO E AGRONEGÓCIO: UMA ANÁLISE DE EQUILÍBRIO GERAL COM BASE NA ESTRUTURA PRODUTIVA BRASILEIRA DE 1995
}

\author{
JOÃO CARLOS VIANNA DE OLIVEIRA
}

Engenheiro Agrônomo

Orientador: Prof. Dr. JOAQUIM BENTO DE SOUZA FERREIRA FILHO

Tese apresentada à Escola Superior de Agricultura

"Luiz de Queiroz", Universidade de São Paulo, para obtenção do título de Doutor em Ciências, Área de Concentração: Economia Aplicada.

PIRACICABA

Estado de São Paulo - Brasil

Janeiro - 2002 
Dados Internacionais de Catalogação na Publicação (CIP) DIVISÃO DE BIBLIOTECA E DOCUMENTAÇÃO - ESALQ/USP

Oliveira, J oão Carlos Vianna de

Sobrevaloriza ção da taxa de câmbio e o agronegócio: uma a nálise de equilíbrio geral com base na estrutura produtiva brasileira de 1995 / J oão Carlos Vianna de Oliveira. - - Piracic aba, 2002.

$173 \mathrm{p}$.

Tese (doutora do) - Escola Superior de Agricultura Luiz de Queiroz, 2002. Bibliografia.

1. Agronégocio 2. Câmbio (economia) 3. Equilíbrio econômico 4. Política cambial I. Título

CDD 338.13

"Permitida a cópia total ou parcial deste documento, desde que citada a fonte - O autor" 
Dedico à minha esposa Eleonora, ao meu filho Danilo, aos meus pais e irmãos. 


\section{AGRADECIMENTOS}

À Deus por nos oferecer saúde e inteligência.

Ao meu orientador Prof. Joaquim Bento, que além da excelência técnica e profissional, sempre foi um amigo.

Ao Curso de Economia Aplicada da ESALQ/USP, por ter acreditado na minha pessoa, em especial à todos os Professores do Departamento.

À Maielli que sempre prontamente auxiliou e se preocupou com o desenvolvimento deste trabalho. Estendemos também o agradecimento às secretárias do Departamento e à equipe da biblioteca, em especial à Luciana e à Ligiana.

Aos meus colegas Silvia, Ricardo, Marcos, Casimiro que sempre estiveram dispostos a ouvir, ajudar e participar.

Aos amigos Marcelo e Gabriel, pelo companheirismo e apoio de longa data. 


\section{SUMÁRIO}

Página

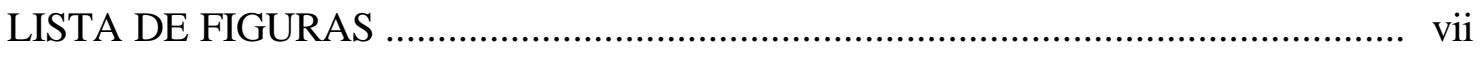

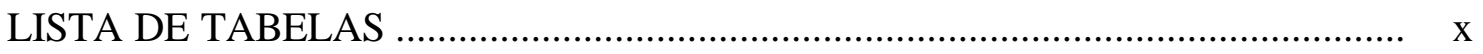

LISTA DE QUADROS ..........................................................................

LISTA DE ABREVIATURAS ................................................................. xiii

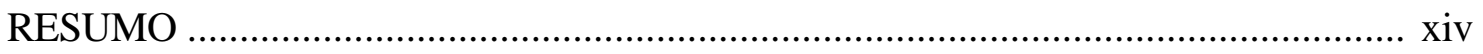

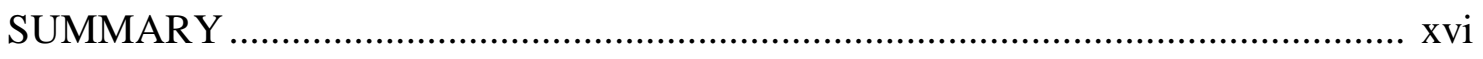

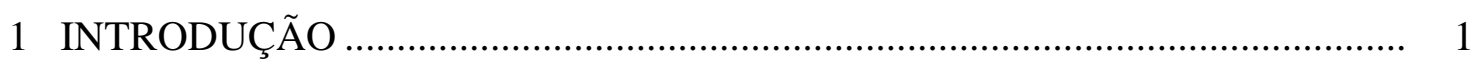

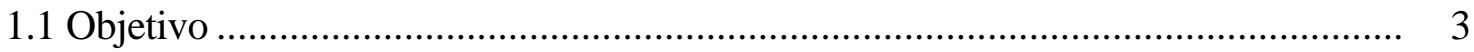

1.2 O Problema e sua importância................................................................... 4

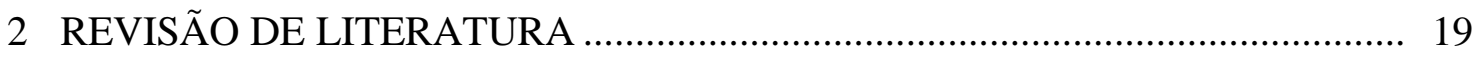

2.1 Políticas macroeconômicas e a agropecuária................................................. 19

2.2 Taxa de câmbio e os incentivos de preço na agropecuária................................ 23

2.3 Modelagem de equilíbrio parcial dos efeitos da taxa de câmbio........................ 26

2.4 Modelagem de equilíbrio geral dos efeitos da taxa de câmbio .......................... 28

2.4.1 Aplicações de equilíbrio geral............................................................. 33

2.4.2 Modelos de equilíbrio geral e as particularidades da agropecuária................. 35

2.4.3 Outros aspectos da modelagem de equilíbrio geral..................................... 37

2.4.4 Limitações dos modelos de equilíbrio geral................................................. 40

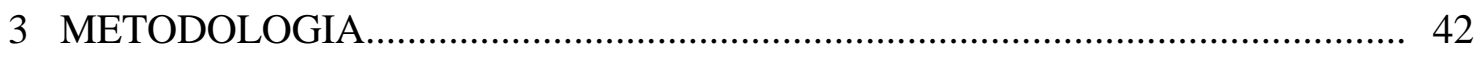

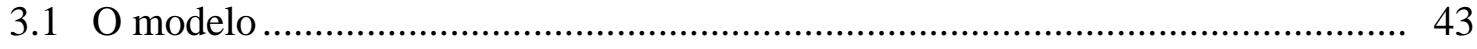

3.1.1 Fundamentos econômicos e pressupostos................................................. 49 
3.1.1.1 Produção ................................................................................................ 49

3.1.1.2 Renda e poupança............................................................................. 51

3.1.1.3 Demanda doméstica............................................................................ 54

3.1.1.4 Comércio exterior e pressupostos.................................................................. 54

3.1.1.5 Preços e normalização ………………………........................................ 56

3.1.1.6 Condições de equilíbrio e fechamento .......................................................... 60

3.1.1.7 Visualização geral do modelo .................................................................. 62

3.1.1.8 Definição dos valores das elasticidades ........................................................ 62

3.2 Matriz de contabilidade social (SAM) ......................................................... 66

3.2.1 Tratamento da matriz de contabilidade social................................................ 67

3.3 Agregações e desagregações ............................................................................... 69

3.3.1 Desagregação do setor agropecuário .............................................................. 72

3.3.2 Desagregação do setor químicos diversos......................................................... 74

3.3.3 Demais critérios adotados nas desagregações .................................................. 75

3.4 Geração e avaliação de impacto sobre o modelo................................................... 76

4 RESULTADOS E DISCUSSÃO ……………………........................................ 79

4.1 Impacto da desvalorização do câmbio sobre as relações externas......................... 80

4.1.1 Exportações ........................................................................................ 81

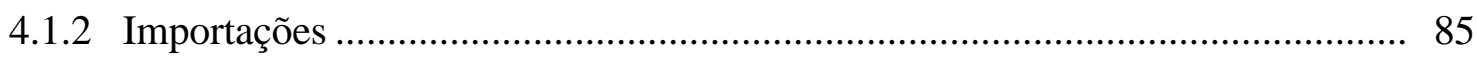

4.2 Impacto da desvalorização do câmbio sobre a produção doméstica ..................... 88

4.3 Impacto da desvalorização do câmbio sobre as relações de troca........................... 105

4.3.1 Termos de troca dos setores agropecuários em relação aos principais setores fornecedores de produtos para o consumo intermediário ...................................... 116

4.3.2 Termos de troca dos setores agroindustriais em relação aos principais setores fornecedores de produtos para o consumo intermediário ...................................... 124

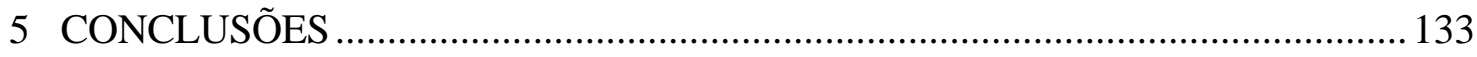

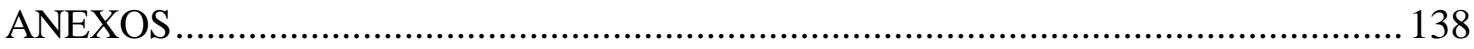

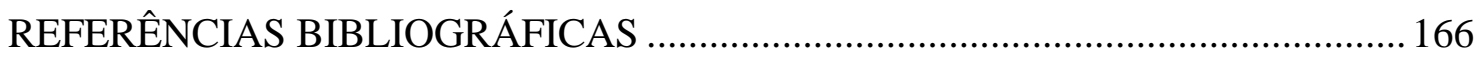




\section{LISTA FIGURAS}

Página

1 Índice da taxa de câmbio real efetiva, (dezembro 1998=100)................................ 5

2 Evolução das vendas de defensivos em valor por categoria..................................... 8

3 Evolução do consumo aparente em volume de fertilizantes ..................................... 9

4 Evolução da produção e da importação em volume de fertilizantes........................ 9

5 Evolução das importações de fertilizantes em volume de equivalente nutriente .... 10

6 Evolução da produtividade das culturas café, soja, laranja e cana-de-açúcar..........11

7 Evolução da produtividade das culturas algodão, arroz, milho e trigo ..................... 12

8 Evolução da produtividade das culturas mandioca, batata, tomate e cebola ............ 12

9 Comportamento das exportações do complexo soja, em volume e em valor...........14

10 Comportamento das exportações de café, em volume e em valor .......................... 14

11 Comportamento das exportações do suco de laranja, em volume e em valor........15

12 Comportamento das exportações de açúcar, em volume e em valor.......................15

13 Comportamento da relação IPR/IPP para as culturas assistidas pela PGPM .........17

14 Comportamento da relação IPR/IPP para as demais culturas ................................. 17

15 Inter-relação entre o setor interno e o resto do mundo .................................................32

16 Participação do Brasil nas exportações e importações mundiais no período de

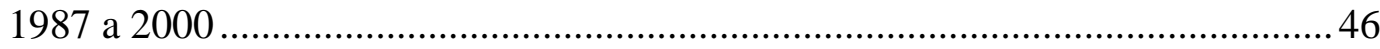

17 Mecanismo de transmissão de preços.................................................................59

18 Representação do fluxo de produtos e equações que definem as relações.............63 
19 Desvalorização da taxa de câmbio nominal referente à reduções marginais do balanço de transações correntes em US\$ 5 bilhões.

20 Impacto da desvalorização da taxa de câmbio nominal sobre as exportações e importações.

21 Participação das exportações com relação à produção doméstica e o impacto da desvalorização da taxa de câmbio.

22 Efeito da desvalorização sobre as exportações por setor.

23 Participação das importações com relação à oferta composta doméstica e o impacto da desvalorização da taxa de câmbio.

24 Efeito da desvalorização sobre as importações por setor.

25 Impacto da desvalorização sobre o preço para a produção setorial. 92

26 Impacto sobre a produção em volume da desvalorização da taxa de câmbio 102

27 Impacto sobre a produção em valor da desvalorização da taxa de câmbio. 107

28 Impacto da desvalorização sobre a renda do trabalho setorial. 108

29 Impacto da desvalorização da taxa de câmbio sobre o preço composto.

30 Índice de custo setorial calculado a partir do impacto da desvalorização sobre o preço composto.

31 Índice de custo setorial extra setor, calculado a partir do impacto da desvalorização sobre o preço composto.

32 Índice IPR/IPP, calculado a partir do impacto da desvalorização sobre o índice de custo e o preço para a produção

33 Índice IPR/IPP, calculado a partir do impacto da desvalorização sobre o índice de custo extra setor e o preço para a produção.

34 Variação da relação preço recebido/preço pago em função da desvalorização (setores café e cana-de-açúcar)......

35 Variação da relação preço recebido/preço pago em função da desvalorização (setores arroz e soja).

36 Variação da relação preço recebido/preço pago em função da desvalorização (setores algodão e milho). 
37 Variação da relação preço recebido/preço pago em função da desvalorização (setores bovinos/suínos e leite natural).

38 Variação da relação preço recebido/preço pago em função da desvalorização (setor outros da agropecuária).

39 Variação da relação preço recebido/preço pago em função da desvalorização (setor madeira/papel e têxtil).

40 Variação da relação preço recebido/preço pago em função da desvalorização (setor indústria do café e beneficiamento de produtos vegetais).

41 Variação da relação preço recebido/preço pago em função da desvalorização (setor abate de animais e indústria de laticínios).

42 Variação da relação preço recebido/preço pago em função da desvalorização (setor indústria do açúcar e indústria de óleos vegetais).

43 Variação da relação preço recebido/preço pago em função da desvalorização (setor outros produtos alimentares) 


\section{LISTA DE TABELAS}

Página

1 Variação em percentagem da participação das importações na oferta total doméstica, no custo intermediário direto e no custo intermediário total entre os anos de 1990 e 1995

2 Decomposição das mudanças no preço doméstico da agricultura entre o período 1990-1994 a 1995-1998.

3 Participação das exportações brasileiras no comércio mundial. .46

4 Valores adotados para as elasticidades de substituição e transformação entre mercado doméstico e externo.

5 Participação percentual do setor i (linha) no consumo intermediário do setor $\mathrm{j}$ (coluna).

6 Participação percentual do setor i (linha) no consumo intermediário do setor $\mathrm{j}$ (coluna), para $\mathrm{i} \neq \mathrm{j}$ (extra setor).

7 Participação do setor j (coluna) no consumo intermediário da produção do setor i (linha).

8 Efeito da desvalorização sobre os preços para a produção da agroindústria no todo e em sub-grupos.

9 Efeito da desvalorização sobre a alteração de preços para a produção da agropecuária no todo e em sub-grupos.

10 Efeito da desvalorização sobre a alteração da produção em valor da agropecuária e da agroindústria no todo e em sub-grupos 
11 Efeito da desvalorização sobre a alteração do IPR/IPP da agropecuária e da

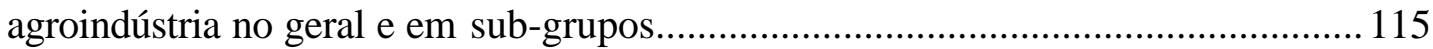




\section{LISTA DE QUADROS}

Página

1 Dados necessários para elaboração da SAM e as respectivas tabelas de origem a partir da Matriz de 1995 e Contas Nacionais de 1995 .............................................6

2 Paralelo entre a estrutura original de setores do IBGE em relação ao modelo ..........70

3 Detalhamento dos critérios utilizados na desagregação do setor agropecuário. ........73

4 Critérios adotados na desagregação dos ítens do valor adicionado............................ 76

5 Grupos de setores tratados no modelo...................................................................... 78 


\section{LISTA DE ABREVIATURAS}

\begin{tabular}{|c|c|c|}
\hline Abreviatura & & Forma por extenso \\
\hline $\mathrm{CAF}$ & - & Café \\
\hline CAN & - & Cana-de-açúcar \\
\hline ARR & - & Arroz em casca \\
\hline SOJ & - & Soja em grão \\
\hline ALG & - & Algodão em caroço \\
\hline MIL & - & Milho em grão \\
\hline $\mathrm{BOV}$ & - & Bovinos e suínos \\
\hline LEI & - & Leite natural \\
\hline AOU & - & Outros produtos agropecuários \\
\hline EXT & - & Extrativa mineral \\
\hline SID & - & Siderurgia \\
\hline MAQ & - & Máquinas e tratores \\
\hline MET & - & Material elétrico \\
\hline AUT & - & Automóveis \\
\hline MAD & - & Madeira e papel \\
\hline QUI & - & Químicos \\
\hline ADU & - & Adubos \\
\hline OQU & - & Outros químicos \\
\hline TEX & - & Indústria têxtil \\
\hline ICAF & - & Indústria do café \\
\hline $\mathrm{BEN}$ & - & Beneficiamento Produtos Vegetais \\
\hline $\mathrm{ABT}$ & - & Abate animais \\
\hline LAC & - & Indústria laticínios \\
\hline $\mathrm{ACU}$ & - & Indústria açúcar \\
\hline OLE & - & Ind. óleos vegetais \\
\hline ALI & - & Outros produtos da alimentação \\
\hline DIV & - & Indústrias diversas \\
\hline SIU & - & SIUP (Serviços de Utilidade Pública) \\
\hline CIV & - & Construção civil \\
\hline MAR & - & Margem Comércio/transporte \\
\hline SER & - & Serviços \\
\hline
\end{tabular}




\title{
SOBREVALORIZAÇÃO DA TAXA DE CÂMBIO E O AGRONEGÓCIO: UMA ANÁLISE DE EQUILÍBRIO GERAL COM BASE NA ESTRUTURA PRODUTIVA BRASILEIRA DE 1995
}

\author{
Autor: JOÃO CARLOS VIANNA DE OLIVEIRA \\ Orientador: Prof. JOAQUIM BENTO DE SOUZA FERREIRA FILHO
}

\section{RESUMO}

Partindo do pressuposto que o agronegócio brasileiro é tipicamente exportador, vários trabalhos, usualmente baseados na análise de equilíbrio parcial, chamaram a atenção para os efeitos adversos das políticas macroeconômicas, que resultaram na sobrevalorização da taxa de câmbio. No entanto, durante o mais recente período de sobrevalorização da taxa de câmbio, ocorrido durante os primeiros anos do Plano Real, a produção agropecuária apresentou ganhos de produtividade, sinalizando a ocorrência de efeitos positivos sobre o setor. Desta forma, o objetivo do trabalho foi analisar o efeito advindo da taxa de câmbio sobre o agronegócio brasileiro, tendo em vista as relações intersetoriais diretas e indiretas características da estrutura produtiva da economia brasileira. Neste sentido, foi adotado um modelo de equilíbrio geral, calibrado para a base de dados de 1995, que foi agregada e desagregada resultando em 32 setores, quais sejam: 9 de produção agropecuária, 9 de produção agroindústrial e 14 outros não- 
agropecuários e não agroindústriais. Cabe destacar que para aperfeiçoar ainda mais o tratamento de dados visando analisar o agronegócio foi realizado o desmembramento dos setores adubos e defensivos. O efeito da taxa de câmbio sobrevalorizada foi avaliado através da desvalorização da taxa de câmbio nominal, induzida pela alteração exógena do balanço de transações correntes. Os resultados obtidos possibilitaram identificar que o agronegócio brasileiro não foi igualmente afetado pela taxa de câmbio. Percebeu-se que os setores com produção non-tradable, que representavam uma parcela significativa da produção total, foram negativamente afetados pela desvalorização, indicando que a sobrevalorização os beneficiava. As relações intersetoriais evidenciaram o efeito positivo que setores agroindustriais exportadores exerceram sobre os seus fornecedores agropecuários. As agroindústrias de alimentação mais focadas no mercado interno exerceram, por outro lado, menor efeito positivo indireto sobre os fornecedores agropecuários. Além da relação das cadeias do agronegócio, também foi constatado que a desvalorização da taxa de câmbio aumentou os preços dos insumos defensivos e fertilizantes, dada a dependência de matérias-primas importadas desses setores. A elevação de preços de insumos afetou diferentemente os setores agropecuários nontradables e os tradables, uma vez que os primeiros não apresentaram aumento de preços para a produção, resultado este evidenciado pelos termos de troca calculados. Concluiuse a partir de uma série de resultados obtidos pelo modelo, que o agronegócio brasileiro, considerando a estrutura produtiva de 1995, não apresentou reação plenamente positiva em resposta à desvalorização, dada a parcela significativa non-tradable de alguns setores. Com o tratamento obtido através da modelagem multisetorial de equilíbrio geral, possibilitou-se um maior realismo da avaliação dos impactos da taxa de câmbio sobre o agronegócio brasileiro, respeitando-se o grau de relação com o mercado externo de cada setor do agronegócio e dos setores com os quais eles se relacionam. A consideração da significativa parcela non-tradable do agronegócio brasileiro foi um aspecto fundamental de diferenciação em relação à estudos anteriores. 


\title{
OVERVALUATION OF EXCHANGE RATE AND AGRIBUSINESS: A GENERAL EQUILIBRIUM ANALYSIS CONSIDERING THE BRAZILIAN PRODUCTIVE STRUCTURE OF 1995
}

\author{
Author: JOÃO CARLOS VIANNA DE OLIVEIRA \\ Adviser: Prof. JOAQUIM BENTO DE SOUZA FERREIRA FILHO
}

\section{SUMMARY}

Assuming that the Brazilian Agribusiness is typically exporter, some papers, usually based on partial framework analysis, bring to discussion the adverse effects of the macroeconomic policies that had resulted in overvaluation of the exchange rate. However, despite the overvaluation of the exchange rate occurred during the first years of the Real Plan, the agricultural sector increased the productivity, showing the existence of some positive effects. So, the object of this research was to evaluate the effect of exchange rate over the agribusiness taking into account the direct and indirect intersector relations of production structure of Brazilian economy. To assess this, it was adopted a general equilibrium model, using the 1995 data as reference, which were aggregated and disaggregated, resulting in 32 sectors, as follows: 9 sectors of agricultural production, 9 agricultural related processing sectors and 14 others non agricultural sectors. It's advisable to mention that, to improve the management of data in order to discuss the agribusiness, it were dismembered fertilizers and pesticides sectors. 
The effect of exchange rate overvaluation was investigated by the devaluation of nominal exchange rate, induced by the exogenous change of trade balance. The results obtained allowed to identify that the exchange rate had quite different effects over the several sectors of Brazilian agribusiness. The sectors with non-tradable production, that represented a significant parcel of the total production, were negatively affected by the devaluation, indicating that the overvaluation had benefited them. The intersectors linkages showed a positive effect when the processing sectors related to exporting agriculture influenced their agricultural production suppliers. On the other hand, the agricultural food-processing oriented to domestic markets had a less positive effect over their agricultural suppliers. Besides the agribusiness chains, it was also detected the effect of exchange rate devaluation on input prices (pesticides and fertilizers), since these inputs had a significant amount of imported raw material. The increase of input prices affected differently the non-tradable and tradable agricultural sectors, because the first ones had not presented a price increase for production. The comparison for both variations was realized through the calculation of terms of trade. The results allowed to conclude that the Brazilian agribusiness, considering the productive structure of 1995 , did not present a fully positive reaction as a response to devaluation, due to the significant non-tradable parcel of some agribusiness sectors. The analysis obtained through the multi- sectorial modeling of general equilibrium gave us a greater realism on impact evaluation of exchange rate on Brazilian agribusiness, considering the level of relationship of the outside market of each agribusiness sector and of their suppliers. It was fundamental, to detach this study from the former ones, to consider the significant non-tradable parcel of Brazilian agribusiness. 


\section{INTRODUÇÃO}

Ao longo do desenvolvimento econômico brasileiro, o setor agropecuário e agroindustrial, que constituem o agronegócio brasileiro, tiveram grande contribuição, principalmente no sentido da geração de divisas para o país. Vários foram os ciclos de culturas, que estimulados por demandas externas específicas, contribuíram para o acúmulo de capital, o que possibilitou o financiamento de investimentos privados e públicos em outros setores.

Do pau-brasil, do couro à cana-de-açúcar no Império, ao café, borracha e cacau nos séculos 19 e 20, passando pelos mais recentes, como o do complexo soja (soja em grão, farelo de soja e óleo) e da laranja (suco de laranja e poupa cítrica), o país se beneficiou de um agronegócio voltado para o mercado externo. Segundo Castro \& Rossi Júnior (2000), as principais commodities brasileiras representavam, em 1980, 70\% das exportações, tendo declinado para $25 \%$ em 1998. Como destacam vários autores estudiosos do processo de desenvolvimento rural, o ciclo do café foi o gerador do capital necessário ao início do processo de industrialização do fim do século 19 e início do século 20. Aliás, o café ainda possui um importante papel na pauta de exportações nacionais, dado que o Brasil ainda detêm uma significativa parcela do mercado internacional.

Concomitantemente à sucessão dos ciclos de culturas que se aproveitavam de oportunidades oferecidas pelo mercado internacional, internamente o país passou por uma série de mudanças sócio-demográficas. A população apresentou elevadas taxas de crescimento, seguida pelo intenso e simultâneo processo de urbanização, com a gradativa redução da parcela residente em zonas rurais. Em resposta, a agropecuária foi 
estimulada a buscar uma maior escala de produção, de forma a atender a crescente demanda urbana por alimentos.

Observou-se a gradativa intensificação de um mercado interno, demandante de alimentos, que cada vez mais, passavam a ser produzidos por uma pequena parcela da população. Diferentemente da produção de subsistência, quando grande parcela da população alocada no setor rural pouco transacionava produtos agropecuários, passou-se a observar o surgimento de uma demanda por produtos agropecuários transacionados em mercados.

Uma parcela da produção agropecuária sempre foi bem definida no sentido do destino para o mercado externo, deste ponto em diante denominada parcela tradable da agropecuária. Por outro lado, uma nova parcela da produção se desenvolvia estimulada por uma demanda por produtos típicos de consumo local, denominada parcela nontradable.

Ao se analisar o agronegócio frente às políticas macroeconômicas adotadas pelo país, em especial a política cambial, é natural esperar que o processo de sobrevalorização da moeda nacional resulte em um efeito negativo. Este fato é constatado em vários trabalhos sobre a política cambial e a agropecuária, principalmente os referentes às práticas advindas da política de industrialização para substituição de importação.

O efeito negativo da sobrevalorização ocorre sobre a parcela tradable da agropecuária e da agroindústria, uma vez que eleva os preços em moeda internacional reduzindo a competitividade das exportações. Por outro lado, sabe-se que a sobrevalorização eleva os preços dos produtos domésticos, aqueles voltados para o mercado interno chamados non-tradables, em relação aos preços dos produtos tradables.

Quando o agronegócio de um país é majoritariamente voltado para o mercado externo, ou seja, a parcela tradable supera o componente non-tradable, o efeito negativo da sobrevalorização prevalece. Por outro lado, se a parcela non-tradable da agropecuária superar a parcela tradable, o efeito positivo compensará o negativo.

A produção agropecuária brasileira ao longo dos anos passou por uma série de mudanças, dentre elas a intensificação da escala de produção com o objetivo do 
atendimento da crescente demanda urbana local, ou seja, a parcela non-tradable desse setor intensificou-se e ganhou participação em relação à parcela tradable.

Ao mesmo tempo, a intensificação do processo de produção tanto da parcela tradable como da non-tradable, baseou-se em insumos de produção com significativa parcela de importação (adubos, medicamentos e defensivos). Sendo assim, a sobrevalorização da taxa de câmbio poderia resultar em efeito positivo através da redução dos preços dos referidos insumos, reduzindo o custo de produção. Por outro lado, a desvalorização poderia resultar em um aumento dos preços desses insumos e consequentemente do custo de produção.

Tendo em vista as considerações apresentadas, percebe-se que a avaliação dos efeitos da taxa de câmbio sobre o desempenho do agronegócio, se estes causaram viés contra ou a favor, depende de uma ponderação das parcelas tradables e non-tradables, bem como, das inter-relações com os demais setores, dentre eles os de insumos. Essa abordagem, por sua vez, tem um caráter de equilíbrio geral, uma vez que as interrelações e a estrutura produtiva devem ser simultaneamente tratadas.

Sabe-se que a parcela non-tradable do agronegócio brasileiro evoluiu para uma significativa participação na produção total, o que faz emergir a hipótese de que a sobrevalorização não estaria associada a um sistemático efeito negativo sobre o agronegócio brasileiro. E esta hipótese será objeto de investigação do presente trabalho.

\subsection{Objetivo}

O objetivo geral deste trabalho é avaliar a resposta dos setores agropecuários e agroindustriais frente a uma desvalorização da taxa de câmbio nominal, como forma de verificação dos efeitos da sobrevalorização da moeda nacional, ocorrido no período entre 1990 e 1999. Para tanto pretende-se, identificar e implementar um modelo que possibilite o adequado tratamento dos efeitos da taxa de câmbio sobre preços relativos e demais variáveis quantitativas da economia. 


\subsection{O problema e sua importância}

Uma vez esgotado o processo de substituição de importações, que norteou as políticas macroeconômicas durante várias décadas, inicia-se à partir de 1988 o processo de abertura comercial do país. Dentro deste contexto de abertura comercial, a moeda nacional passou a ser gradativamente valorizada. Segundo Agénor et al. (1997), uma das causas da apreciação da moeda nacional foi o forte fluxo de capital que o país passou a receber a partir do início dos anos 90, associado com mudanças no sentido de maior liberalização de investimento estrangeiro no mercado financeiro. Destacam ainda que a taxa de juros influenciou significativamente as flutuações do fluxo de capital e da resultante taxa de câmbio real.

A política cambial do Plano Real contribuiu ainda mais para a apreciação da moeda, ao instituir o sistema de bandas cambiais (sistema de flutuação "suja"), utilizado como âncora dos preços internos. A evolução da taxa de câmbio real, aquela que efetivamente gera influência sobre os preços relativos, pode ser vista na Figura 1. Como pode ser observado, a política adotada para a taxa de câmbio nominal no Brasil durante o período de 1994 a 1998, resultou na menor (a mais sobrevalorizada) taxa de câmbio real dos últimos anos. 


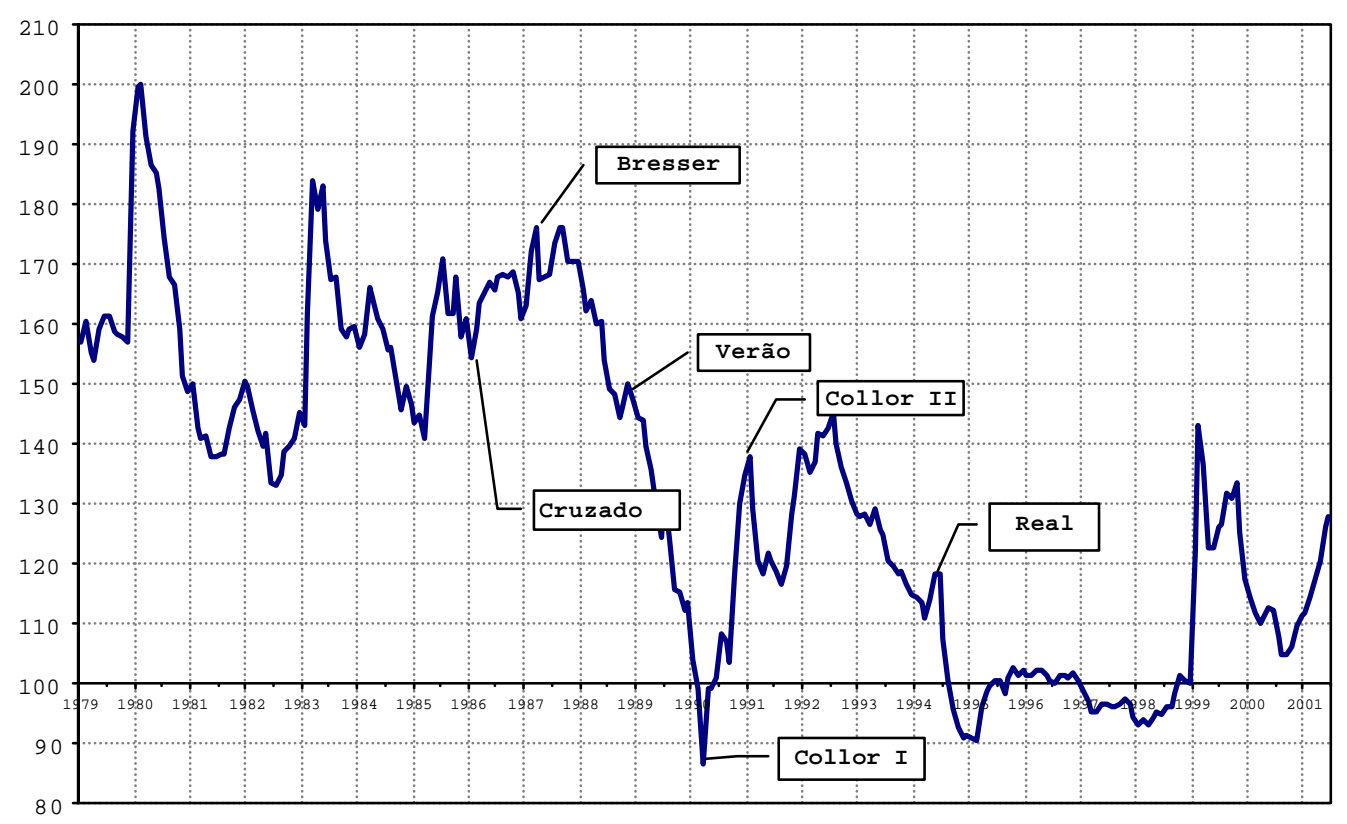

Figura 1 - Índice da taxa de câmbio real efetiva ${ }^{1}$ (dezembro 1998=100).

(Fonte: Instituto de Pesquisa Econômica Aplicada - IPEA, 2001)

A questão da valorização da moeda nacional está dentro do contexto maior de estabilização e abertura comercial implementados na década de 90. Segundo Oliveira Júnior (2000), o processo de abertura baseou-se na eliminação das barreiras não-tarifárias às importações, assim como, na redução substancial das tarifas. A resposta ao processo de abertura comercial e à valorização da moeda nacional tem um dos seus indicativos no aumento da participação das importações na oferta doméstica total, como apresentado na Tabela 1.

Segundo os dados apresentados na Tabela 1, observa-se que ocorreu grande variação da participação dos importados na composição da oferta doméstica, refletindo que a economia brasileira ficou mais aberta ao mercado externo. Chama-se a atenção

\footnotetext{
${ }^{1}$ Calculada pelo deflacionamento do IPA-OG (índice de preços no atacado - oferta global) e dos IPAs dos 15 mais importantes parceiros comerciais do Brasil da série nominal de taxa de câmbio R $\$ / U S \$$, ponderada pela participação de cada parceiro na pauta do total das exportações brasileiras.
} 
para o caso das grandes variações da participação dos importados, que invariavelmente estão associadas com um valor base inicial muito pequeno.

No que diz respeito à participação das importações no processo produtivo, Oliveira Júnior (2000) verificou o consumo intermediário de importados em relação ao valor da produção setorial, denominado de coeficiente de custo direto. Na segunda coluna de dados da Tabela 1, percebe-se que a variação do coeficiente de custo direto foi positiva para a grande maioria dos setores, indicando que todos passaram a gastar mais com insumos importados, mesmo diante de um processo de redução de tarifas e valorização da moeda nacional. Os autores ressaltam ainda que as alterações apresentadas não estão associadas à uma significativa mudança estrutural, uma vez que, os setores que apresentaram as maiores variações são os que já recorriam à importações no início do processo de abertura. Rodrigues \& Guilhoto (1998) também fazem a mesma ressalva, destacando que as mudanças estruturais não foram significativas no período entre 1990 e 1995.

No coeficiente de custo total, além das importações diretas de um setor, considera-se também as realizadas pelos seus fornecedores. Conforme se apresenta na terceira coluna da Tabela 1, alguns setores apresentaram variação negativa do coeficiente de custo total, dentre eles a agropecuária, a indústria do café, o beneficiamento de produtos vegetais, o abate de animais e a indústria de laticínios. Os referidos setores, considerados por Oliveira Júnior (2000) como uns dos mais fechados ao comércio internacional, apresentaram redução da participação dos importados em sua composição de custo total, sinalizando que se passou a gastar menos com insumos importados direta e indiretamente. Neste ponto, destaca-se um indício de que o processo de valorização da moeda nacional, ou sobrevalorização da taxa de câmbio, apresentou efeitos diferenciados entre os setores tradables e non-tradables, podendo para estes últimos ter gerado benefícios.

Ocorre no entanto que os efeitos estão conjugados, principalmente a redução de tarifas e a taxa de câmbio, o que não permite identificar com clareza o efeito apenas da taxa de câmbio. 
Tabela 1. Variação em percentagem da participação das importações na oferta total doméstica, no custo intermediário direto e no custo intermediário total entre os anos de 1990 e 1995.

\begin{tabular}{|c|c|c|c|}
\hline \multirow[t]{2}{*}{ Setor } & \multicolumn{3}{|c|}{ Variação \% } \\
\hline & $\begin{array}{c}\text { oferta } \\
\text { doméstica }\end{array}$ & $\begin{array}{l}\text { custo } \\
\text { direto }\end{array}$ & $\begin{array}{l}\text { custo } \\
\text { total }\end{array}$ \\
\hline Agropecuária & 51.9 & 48.8 & -3.5 \\
\hline Extrativa mineral & 4.4 & -6.1 & 3.6 \\
\hline Exploração de petróleo e gás & $-12 \cdot 5$ & 16.4 & -3.1 \\
\hline Minerais não-metálicos & 124.2 & 8.4 & -3.8 \\
\hline Siderurgia & 45.2 & 19.6 & 13.7 \\
\hline Metalurgia (não-ferrosos) & 106.3 & 48.9 & 32.4 \\
\hline Máquinas e tratores & 69.8 & 112.1 & 34.6 \\
\hline Material elétrico & 71.8 & 84.3 & 43.0 \\
\hline Equipamentos eletrônicos & 80.2 & 91.8 & 57.2 \\
\hline Automóveis, caminhões e ônibus & 3073.6 & 294.2 & 102.4 \\
\hline Outros veículos e peças & 63.0 & -4.2 & 3.0 \\
\hline Madeira e mobiliário & 218.6 & 42.2 & $-1 \cdot 7$ \\
\hline Papel e gráfica & 129.4 & 88.7 & 45.3 \\
\hline Indústria da borracha & 99.8 & 55.7 & 18.5 \\
\hline Elementos químicos & 22.1 & $-11 \cdot 0$ & $-11 \cdot 6$ \\
\hline Refino do petróleo & 157.0 & -21.8 & $-18 \cdot 4$ \\
\hline Químicos diversos & 61.3 & 37.7 & 24.1 \\
\hline Farmacêutica e perfumaria & 79.0 & 12.2 & 3.5 \\
\hline Artigos plásticos & 215.0 & 174.3 & 26.0 \\
\hline Indústria têxtil & 317.0 & 205.2 & 70.0 \\
\hline Artigos do vestuário & 468.5 & 393.9 & 23.0 \\
\hline Fabricação de calçados & 98.6 & 29.0 & 15.1 \\
\hline Indústria do café & 0.0 & -25.0 & -16.1 \\
\hline Benefiaciamento prod. vegetais & 40.8 & $-10 \cdot 3$ & -7.4 \\
\hline Abate de animais & -46.5 & -1.9 & -5.5 \\
\hline Indústria de laticínios & 108.1 & 68.8 & -7.5 \\
\hline Indústria de açúcar & 0.0 & 37.1 & 11.8 \\
\hline Fabricação de óleos vegetais & 196.0 & 230.7 & 38.0 \\
\hline Indústria diversas & 188.0 & 263.9 & 21.4 \\
\hline
\end{tabular}

Agregando mais informação sobre a reação da produção agrícola ao processo de abertura comercial associado à valorização da moeda nacional, pode-se analisar melhor a questão da utilização de insumos de produção. Além da importância dos defensivos e dos fertilizantes para a produção da agropecuária brasileira, sabe-se que os referidos insumos apresentam uma importante base de importação, o primeiro quanto aos 
princípios ativos e o segundo quanto às matérias primas pouco disponíveis no país (como por exemplo, o cloreto de potássio).

Na Figura 2 apresenta-se a evolução do valor das vendas de defensivos no total e por categoria. Com exceção das vendas de acaricidas, as demais categorias e o total de vendas de defensivos apresentaram um aumento significativo no período entre 1990 e 1999, indicando que durante a valorização da moeda, a agricultura intensificou o uso desses insumos. Ao mesmo tempo, foi observado significativo aumento para o consumo aparente de fertilizantes durante o mesmo período, como pode ser notado na Figura 3. Assim, como no caso dos defensivos, o consumo praticamente dobrou na primeira metade da década de 90. Verificando a questão da importação de fertilizantes, nota-se que enquanto a produção interna cresceu no período 1,4 vezes, a importação cresceu aproximadamente 2,5 vezes, indicando um aumento da participação de fertilizantes importados na oferta doméstica (Figura 4).

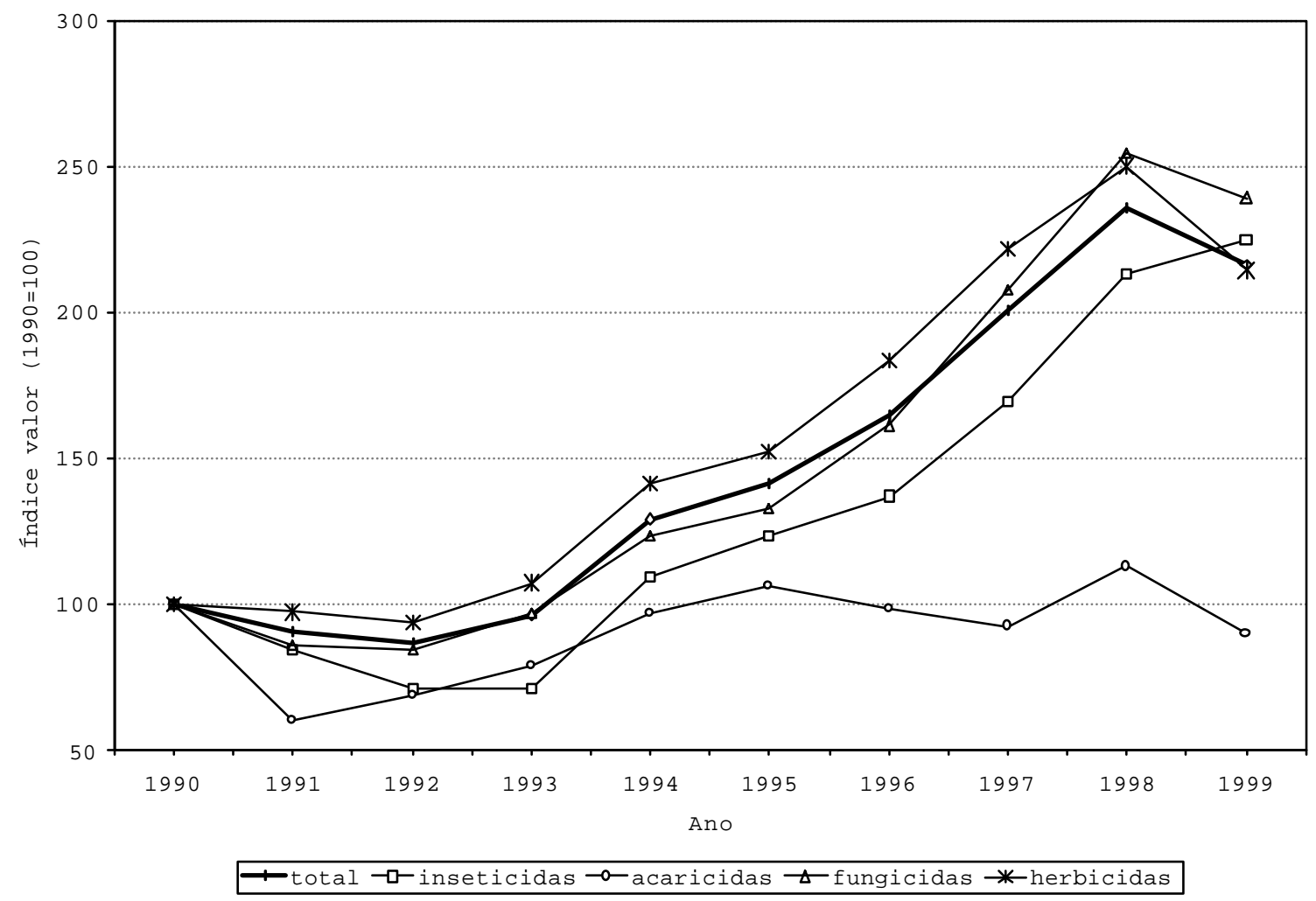

Figura 2 - Evolução das vendas de defensivos em valor por categoria. (Fonte: Sindicato Nacional das Indústrias para Defesa Agrícola - SINDAG, 2001) 


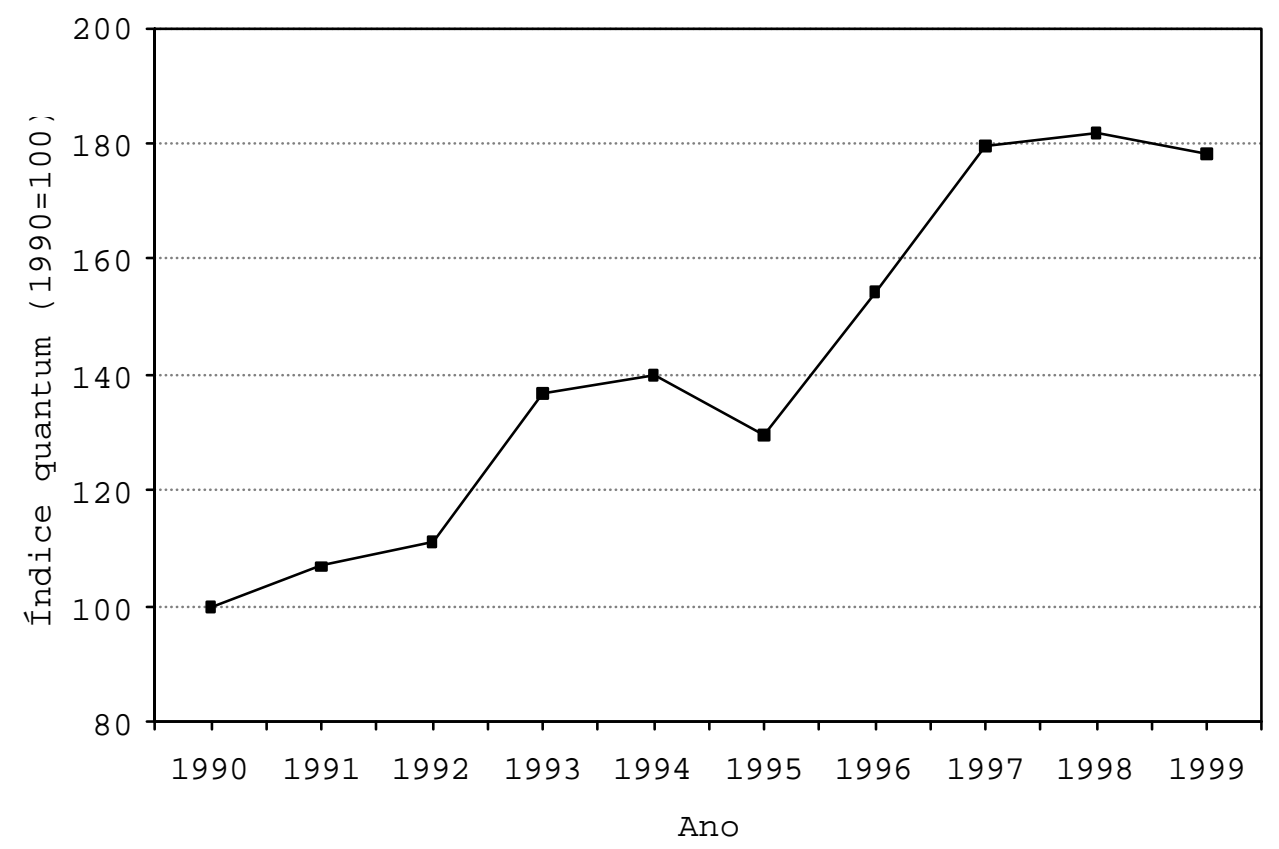

Figura 3 - Evolução do consumo aparente em volume de fertilizantes.

(Fonte: Ministério da Agricultura, 2001)

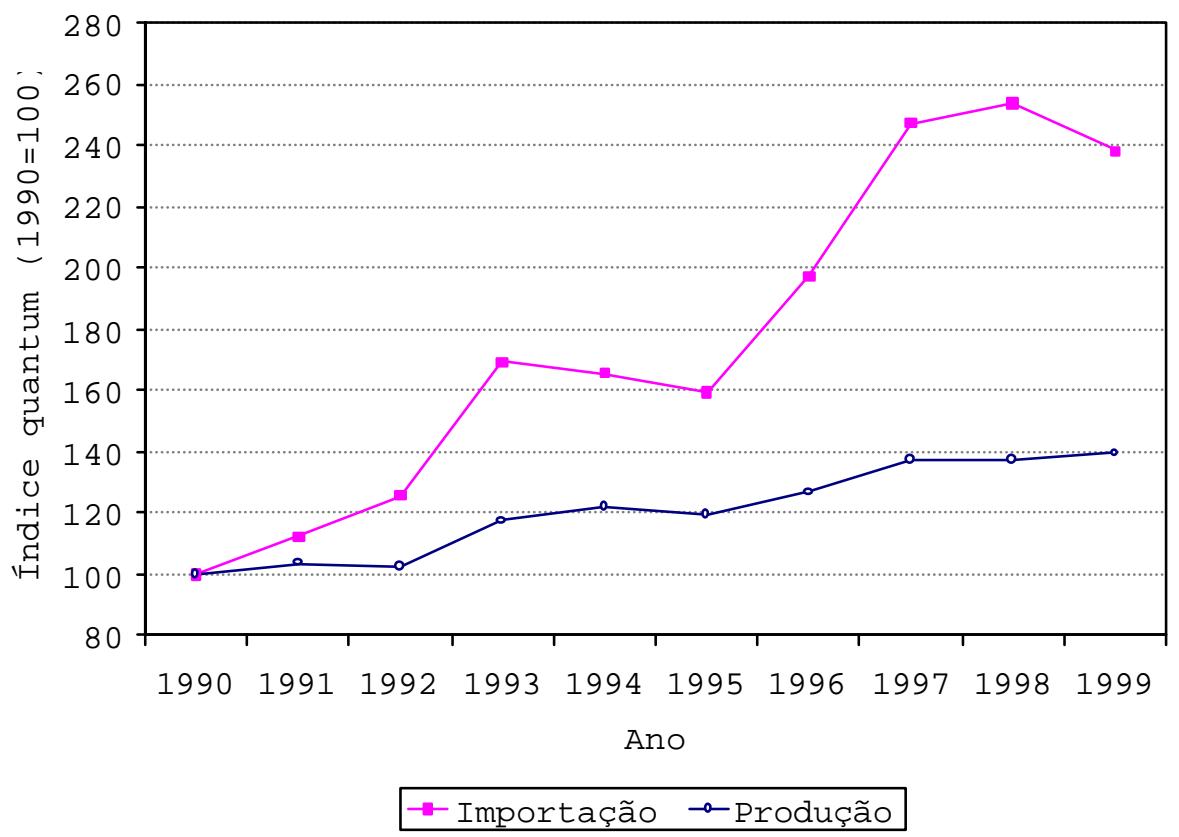

Figura 4 - Evolução da produção e da importação em volume de fertilizantes.

(Fonte: Ministério da Agricultura, 2001) 


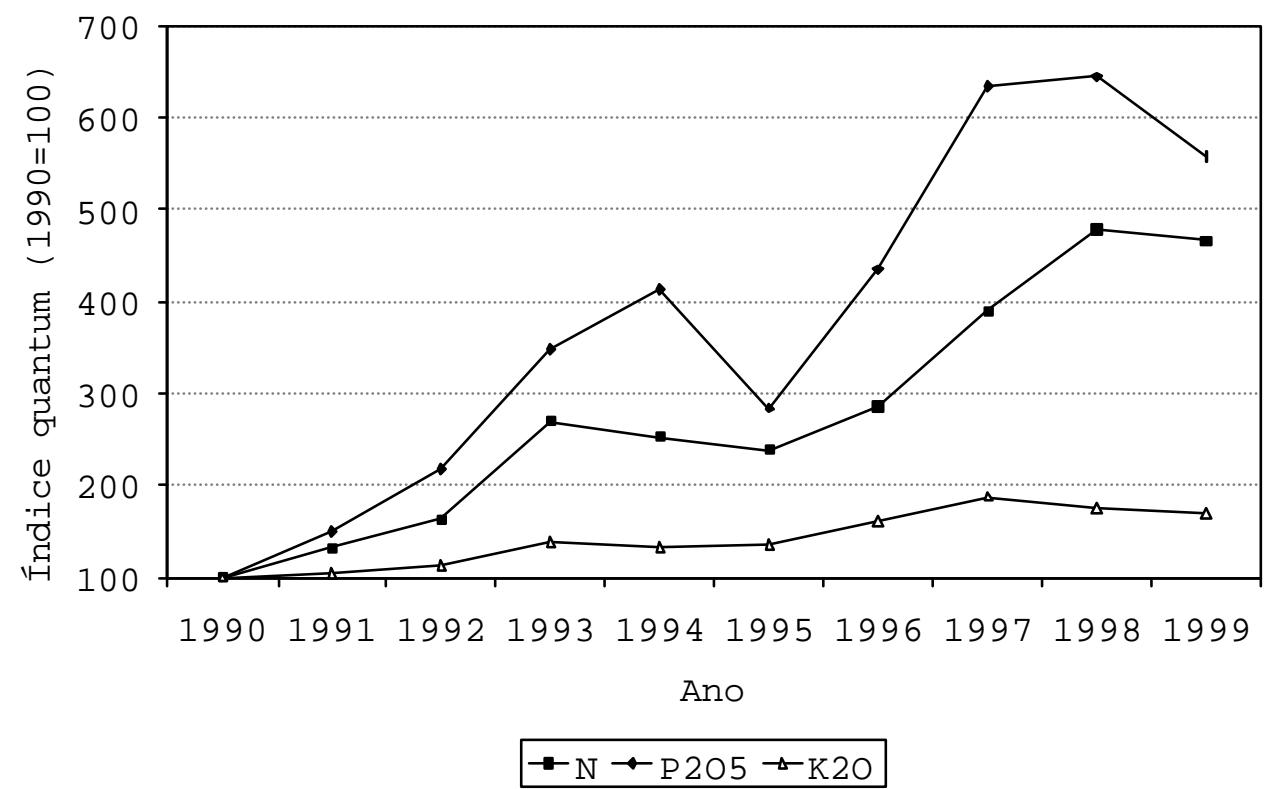

Figura 5 - Evolução das importações de fertilizantes em volume de equivalente nutriente. (Fonte: Ministério da Agricultura, 2001)

Analisando a importação por nutrientes (Figura 5), percebe-se que passou-se a importar nitrogênio $(\mathrm{N})$ e fosfato $\left(\mathrm{P}_{2} \mathrm{O}_{5}\right)$ de uma forma mais acentuada, ao passo que cloreto de potássio $\left(\mathrm{K}_{2} \mathrm{O}\right)$ sofreu menos alteração. Este comportamento caracteriza a nova tendência de importação de produtos que não somente são escassos no mercado doméstico, como é o caso do cloreto de potássio, mas que também sejam interessantes economicamente.

A maior utilização de defensivos e fertilizantes, estimulada pela queda de preços destes insumos advinda da abertura comercial e da valorização da moeda nacional, contribuiu para a melhoria da produtividade das culturas café, soja, laranja e cana-deaçúcar, relacionadas com a produção de commodities de exportação (Figura 6). As culturas anuais café e laranja apresentam um comportamento típico de culturas perenes com alternância de produtividade. 


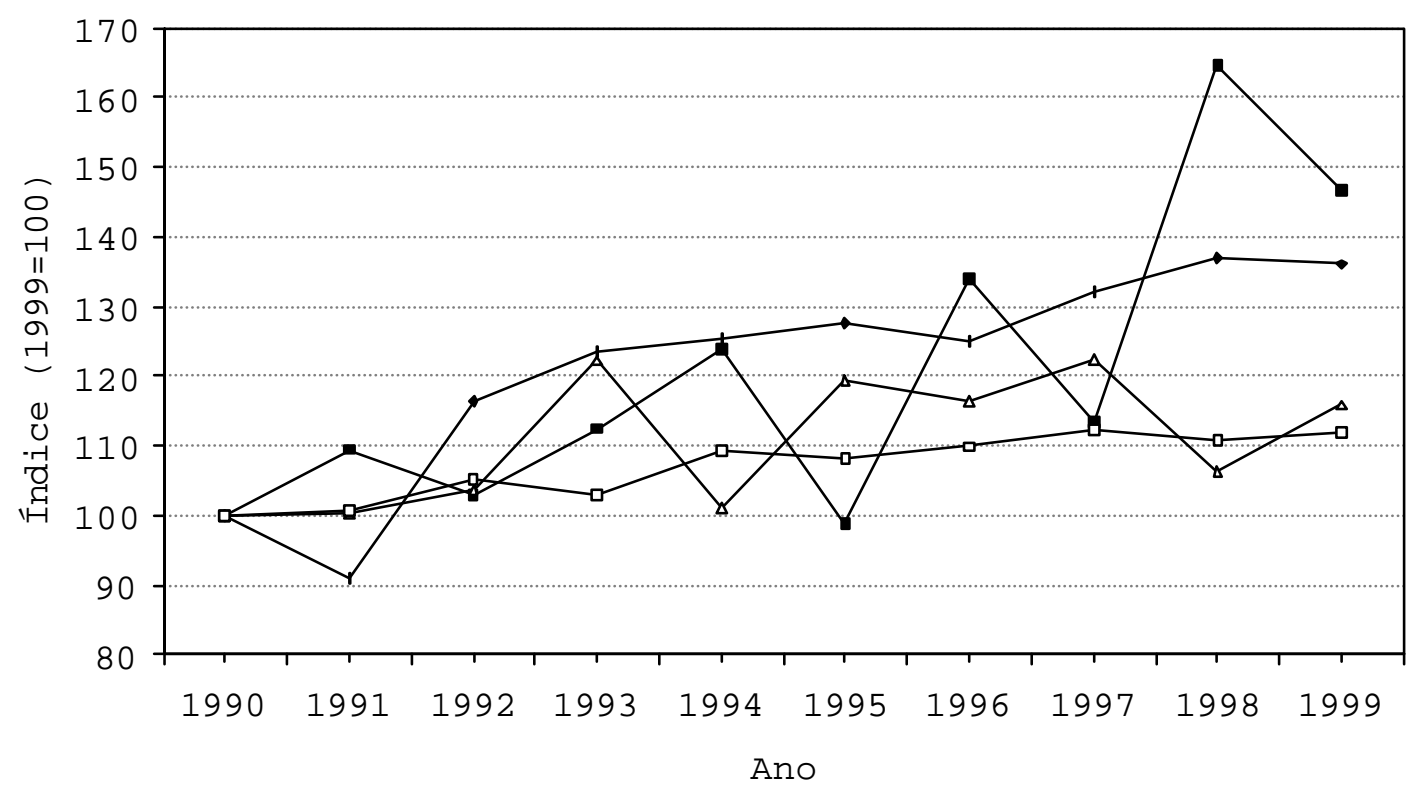

$\rightarrow$ café $\rightarrow$ soja $\rightarrow$ laranja $\rightarrow$ cana

Figura 6 - Evolução da produtividade das culturas café, soja, laranja e cana-de-açúcar. (Fonte: Ministério da Agricultura, 2001)

Também se observa o ganho de produtividade para as culturas algodão, arroz, milho e trigo, conforme o comportamento das curvas na Figura 7. Sob o ponto de vista da relação com o mercado externo, as referidas culturas podem ser consideradas tradables substitutas de importação. Observando o comportamento da produtividade para culturas mais voltadas para o mercado interno, conforme a Figura 8, verifica-se um padrão mais disperso, mas ainda sinalizador de um aumento de produtividade. Com exceção da cultura da mandioca, as demais apresentaram melhora da produtividade em relação ao ano base de 1990. 


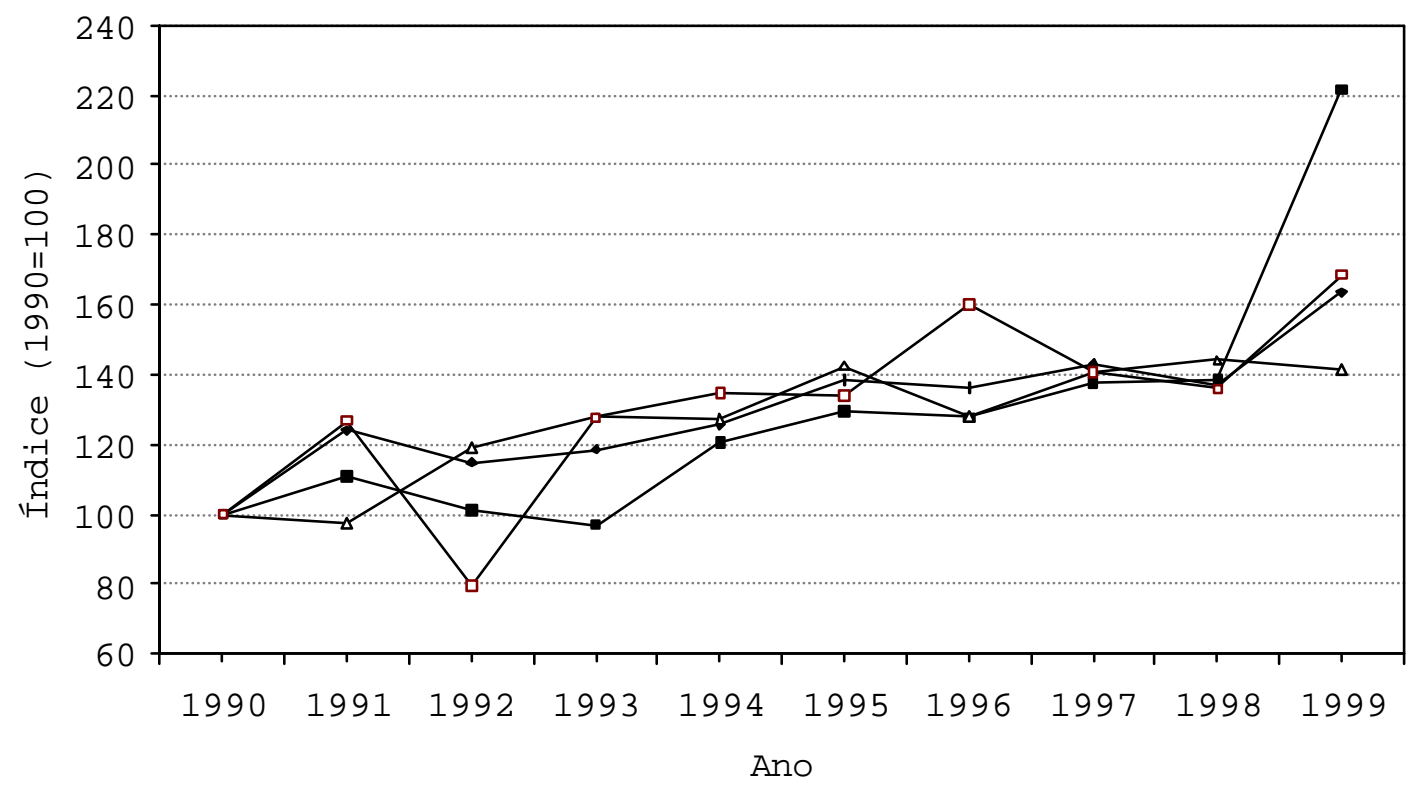

$\rightarrow$ algodão $\rightarrow$ arroz $\rightarrow$ milho ${ }^{-}-$trigo

Figura 7 - Evolução da produtividade das culturas algodão, arroz, milho e trigo. (Fonte: Ministério da Agricultura, 2001)

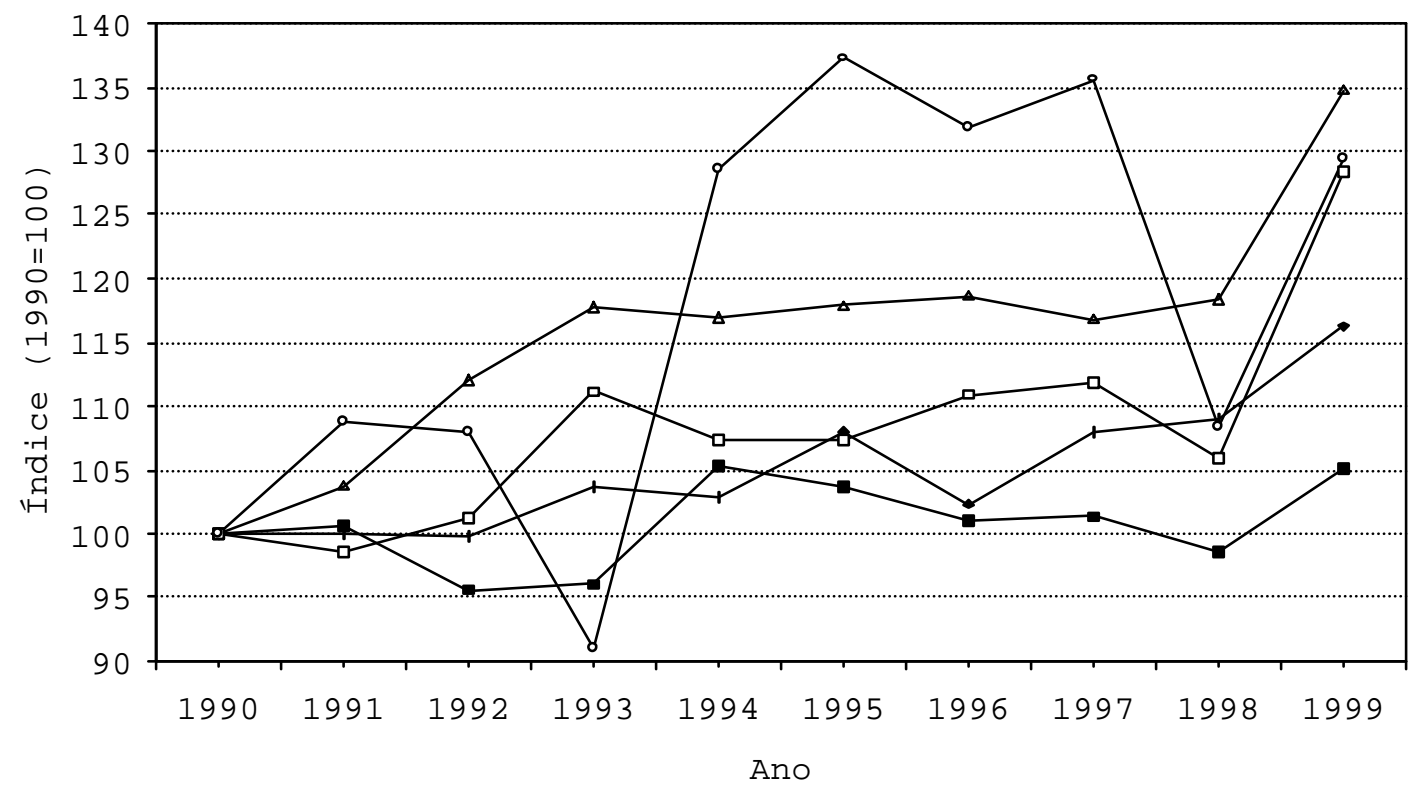

mandioca $\rightarrow$ batata $\rightarrow$ tomate $\rightarrow$ cebola $\rightarrow$ feijão

Figura 8 - Evolução da produtividade das culturas mandioca, batata, tomate e cebola. (Fonte: Ministério da Agricultura, 2001) 
De acordo com os dados de produtividade, constata-se que durante o período de abertura comercial e valorização da moeda nacional, observou-se ganhos no processo produtivo agropecuário, fato este também ressaltado por Ferreira Filho (2000). Segundo Helfand \& Rezende (2001), o processo de valorização da moeda foi um significativo elemento promotor do aumento da produtividade, em função da redução dos preços dos insumos importados. Por outro lado, destacam que a sobrevalorização agravou o processo de competição exercido pelos produtos importados, reduziu os ganhos das culturas de exportação e gerou pouca pressão sobre os setores non-tradables.

As culturas voltadas para a exportação, chamadas tradables de exportação, apresentaram ganhos de produtividade, como já foi retratado; por outro lado, o processo de valorização da moeda contribuiu para a redução do rendimento em moeda nacional das exportações. Segundo Schuh (1998), a sobrevalorização gerou um efeito prejudicial aos setores tradables, pois as exportações perderam competitividade e a concorrência interna se intensificou, mesmo considerando os ganhos de produtividade ocorridos no período.

Ocorre que os efeitos negativos, principalmente da sobrevalorização da taxa de câmbio, foram compensados pelo cenário favorável do mercado internacional na época. Como pode ser observado nas Figuras 9 a 12, as principais commodities de exportação brasileiras apresentaram volume em toneladas e valor em dólar crescentes ao longo do período estudado. Desta forma, o efeito negativo exercido pela valorização da moeda nacional foi amenizado pelo efeito positivo da demanda internacional, dificultando assim, a separação do quanto realmente a taxa de câmbio interferiu no desempenho dos setores agropecuários e agroindustriais tradables de exportação. 
Complexo soja

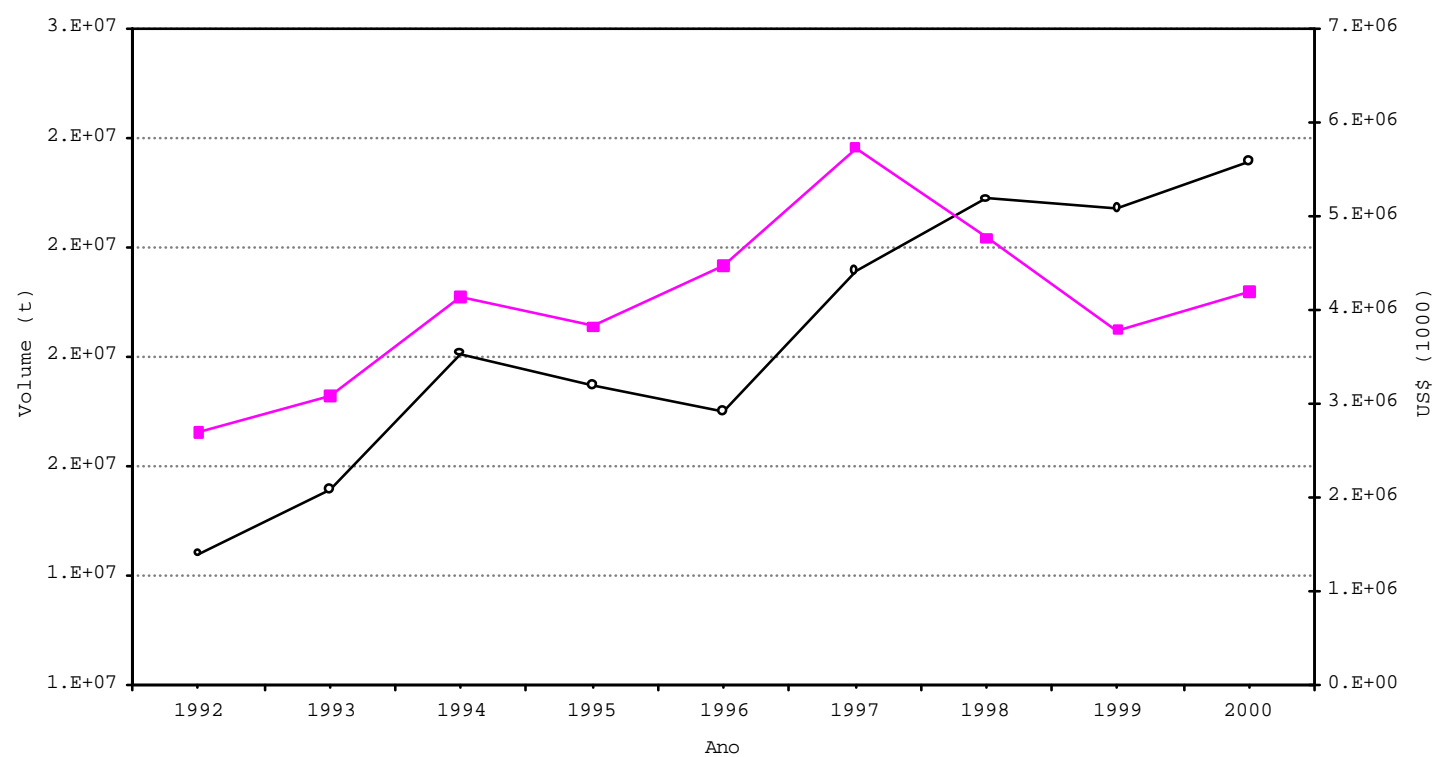

-0-volume $\rightarrow$-valor

Figura 9 - Comportamento das exportações do complexo soja, em volume e em valor. (Fonte: Banco Central do Brasil - BACEN, 2001)

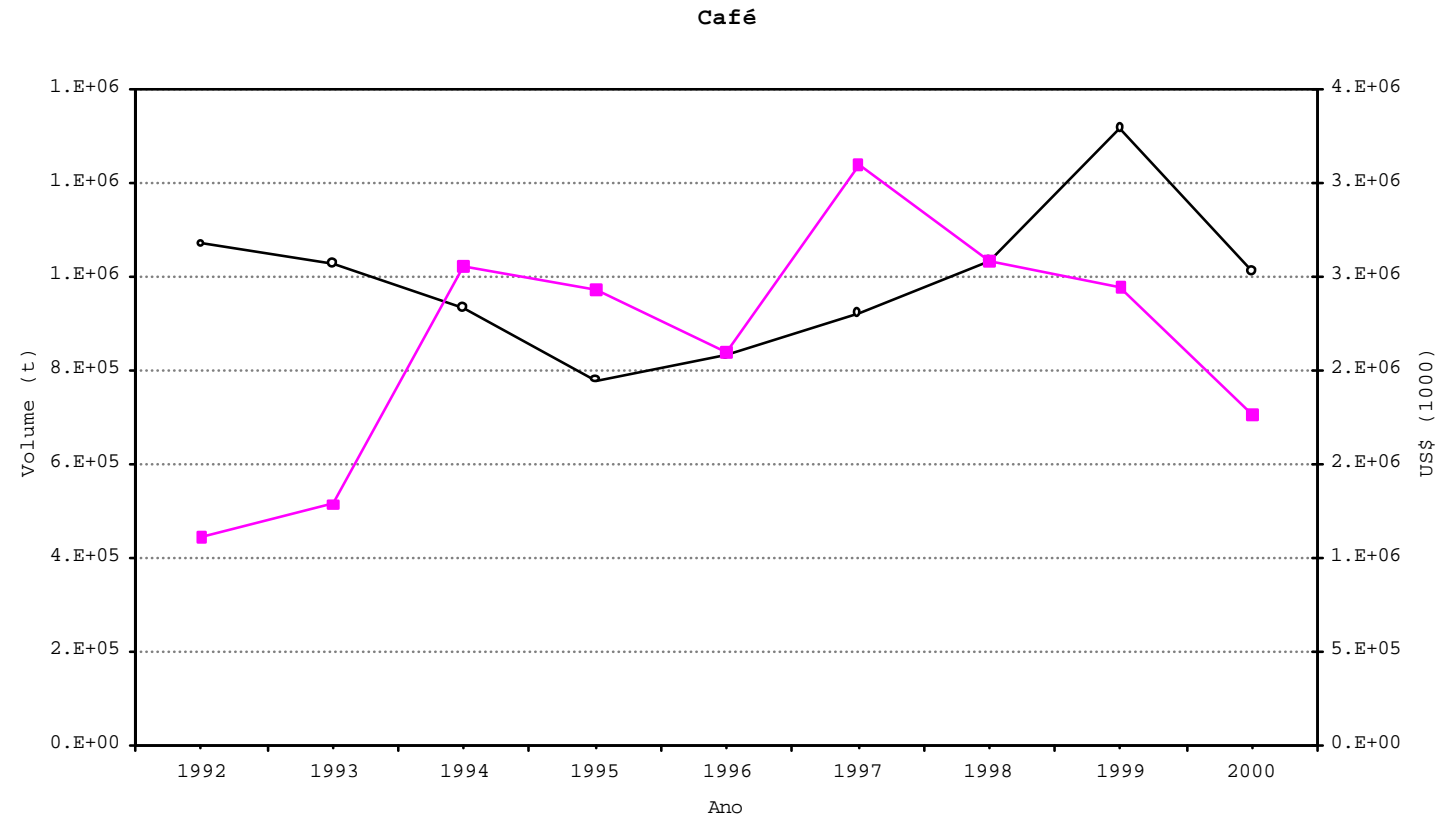

$\rightarrow$ volume $\rightarrow$-valor

Figura 10 - Comportamento das exportações de café, em volume e em valor. (Fonte: BACEN, 2001) 
Suco laranja

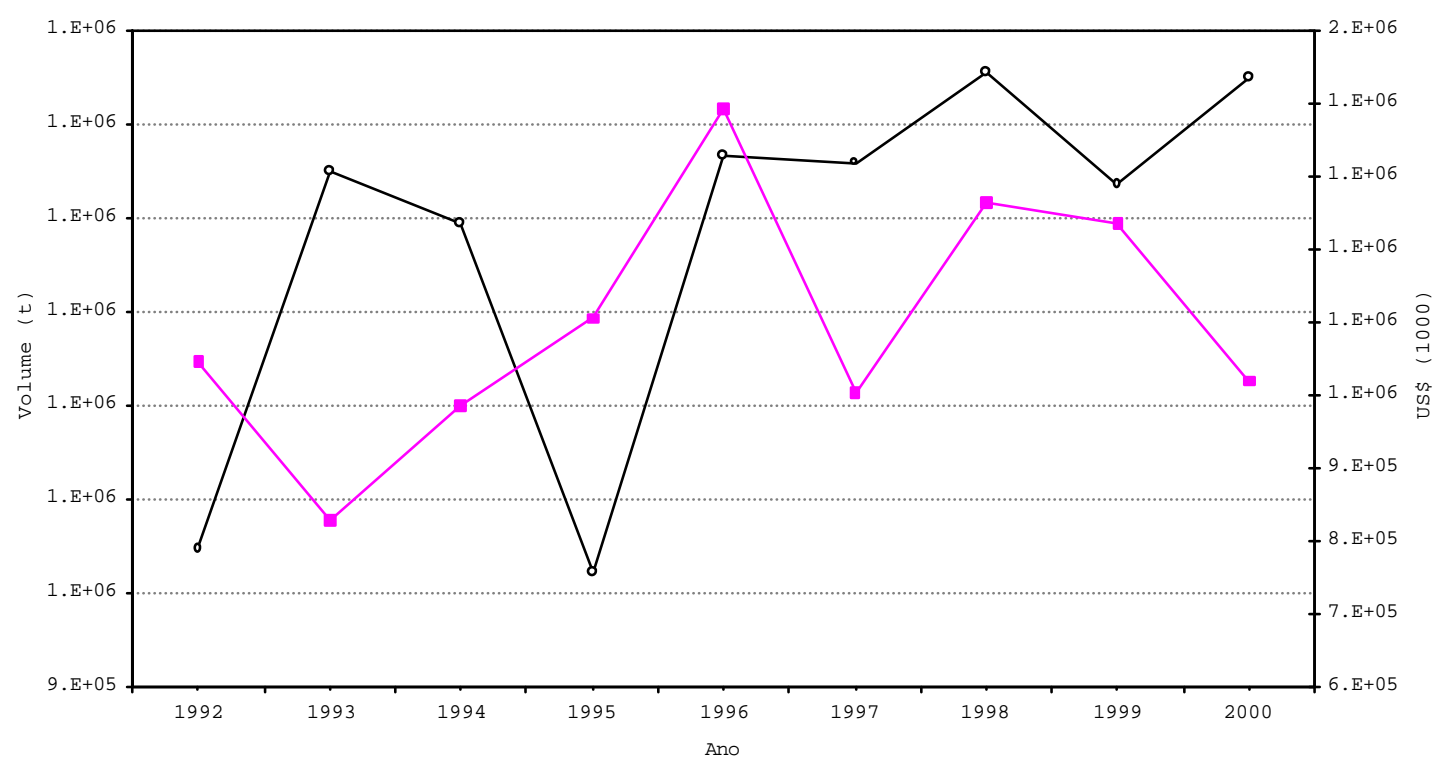

-o-volume $\rightarrow$-valor

Figura 11 - Comportamento das exportações do suco de laranja, em volume e em valor. (Fonte: BACEN, 2001)

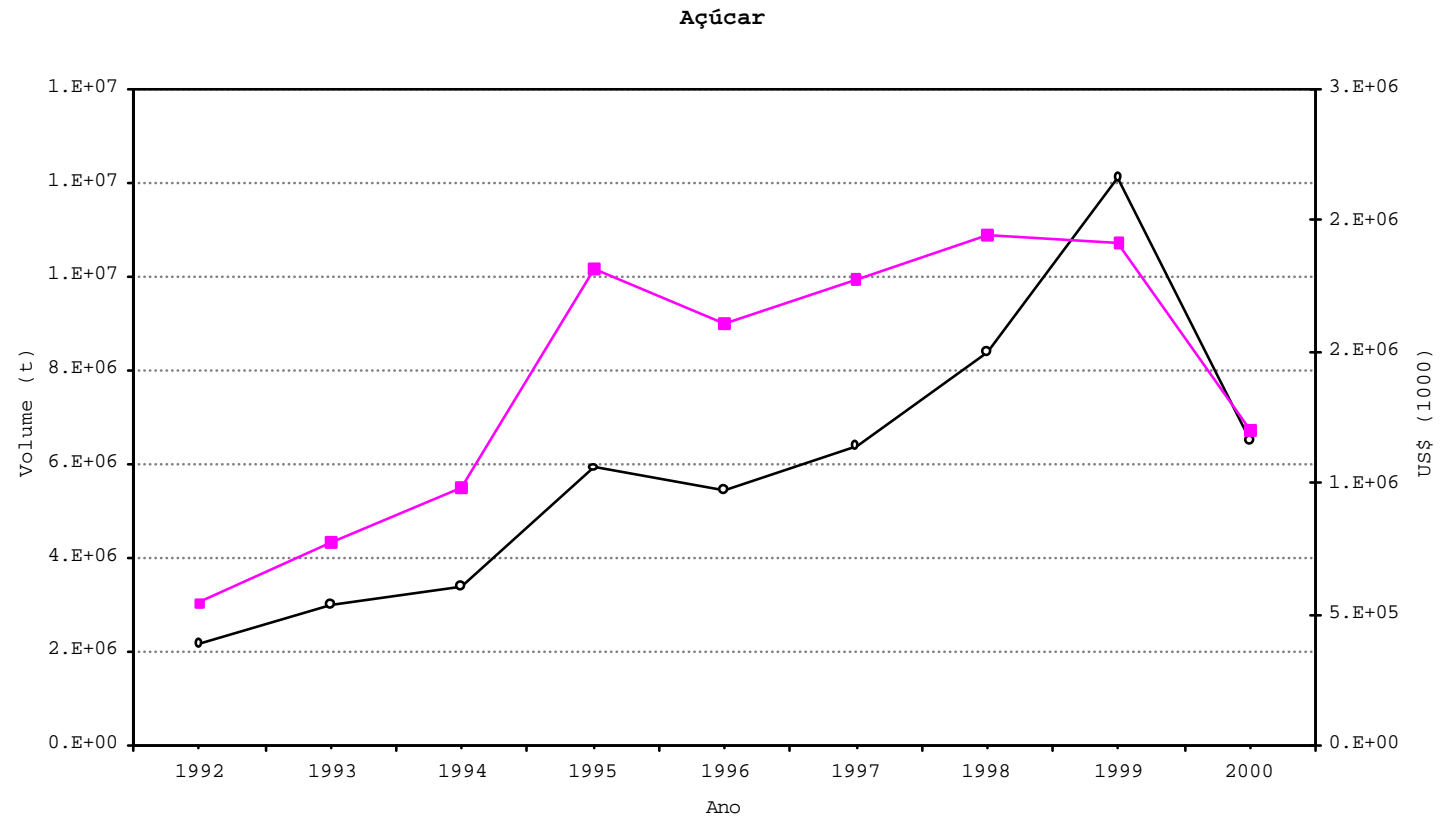

- - volume $\rightarrow$-valor

Figura 12 - Comportamento das exportações de açúcar, em volume e em valor. (Fonte: BACEN, 2001) 
Uma outra forma de se verificar o comportamento da agropecuária frente às modificações ocorridas no período estudado, é através da análise da relação preços recebido por preço pago (IPR/IPP). A CONAB (Companhia Nacional de Abastecimento) calcula o índice de preços recebidos e o índice de preços pagos para as culturas assistidas pela Política de Garantia de Preços Mínimos (PGPM²) e demais lavouras.

Nas Figuras 13 e 14 apresenta-se o comportamento do IPR/IPP no período de 1994 a 1999, sendo o IPP relativo a fertilizantes e defensivos, para os dois grupos de atividade tratados pela CONAB. Durante o período analisado, conforme foi apresentado na Figura 1, a taxa de câmbio real efetiva se manteve relativamente estável em seu patamar mais valorizado. Percebe-se que para as culturas assistidas pelo PGPM, ocorreu uma tendência de melhoria do preço recebido em relação ao preço pago, conforme o gráfico da Figura 13. Nota-se também a relação antagônica entre a variação taxa de câmbio real e a do IPR/IPP, principalmente para os pontos de valorização e desvalorização mais acentuados. Analisando os resultados para as demais culturas (Figura 14), não se percebe uma tendência de crescimento da relação IPR/IPP. Houve, por outro lado, uma melhoria da relação quando a taxa de câmbio real se valorizou.

${ }^{2}$ O PGPM inclui as seguintes culturas: algodão, amendoim, alho, arroz, aveia, canola, castanha-de-caju, cera de carnaúba, centeio, cevada, feijão, girassol, guaraná, juta, mamona, mandioca, milho, sementes de cereais, sisal, soja, sorgo, trigo, triticale e uva. 


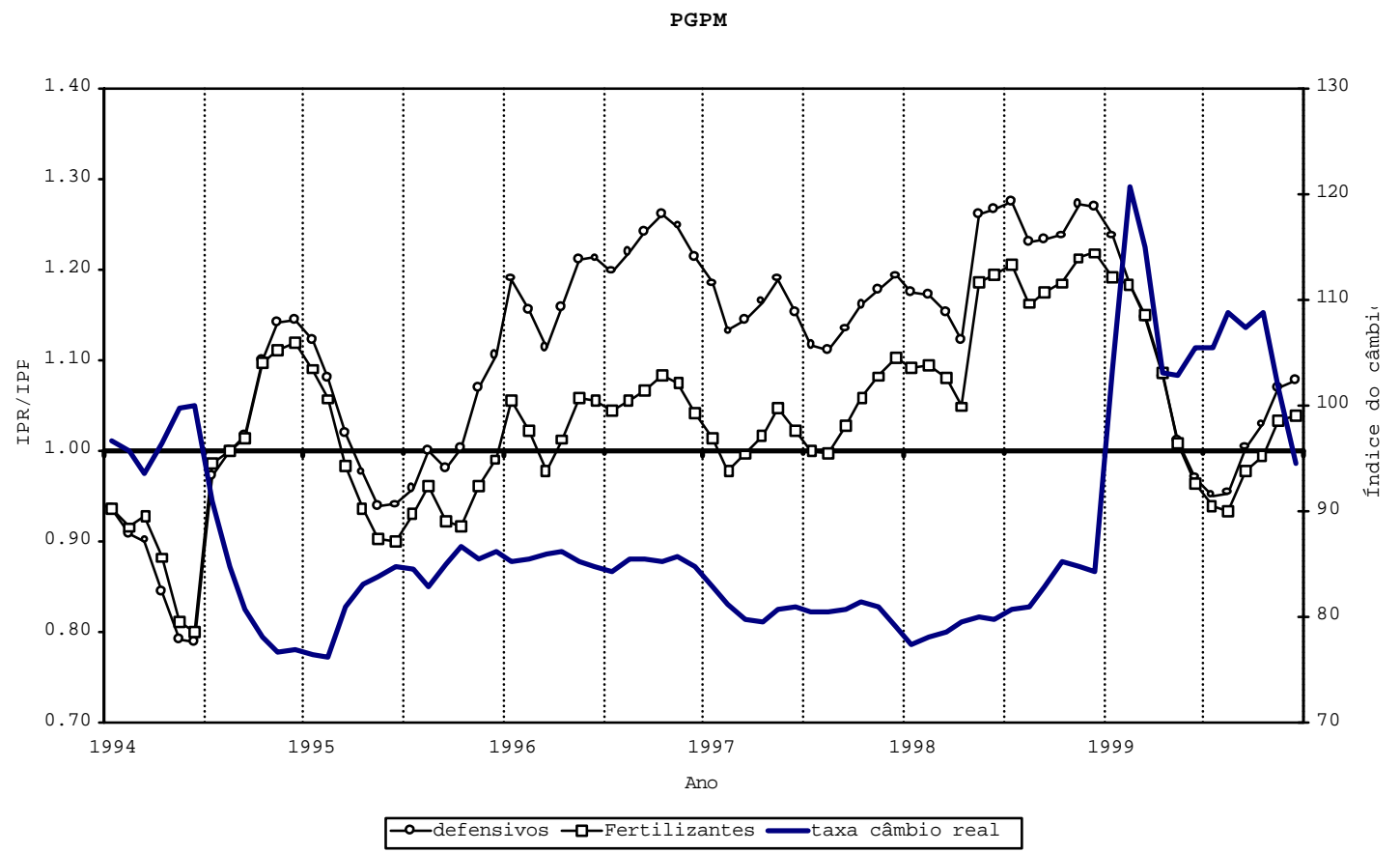

Figura 13 - Comportamento da relação IPR/IPP para as culturas assistidas pela PGPM. (Fonte: Companhia Nacional de Abastecimento - CONAB, 2001)

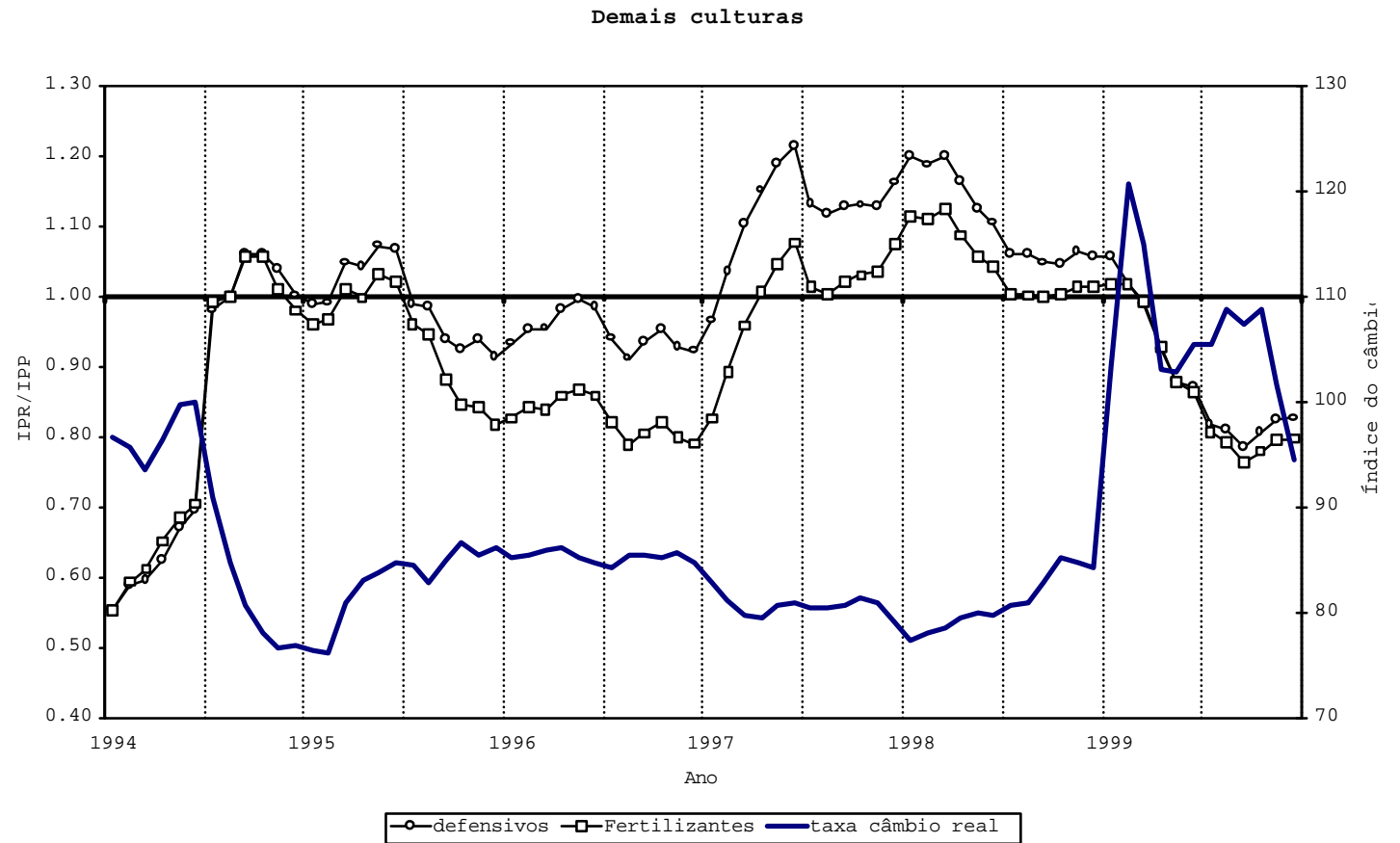

Figura 14 - Comportamento da relação IPR/IPP para as demais culturas. (Fonte: CONAB, 2001) 
Percebe-se que no período onde a taxa de câmbio real esteve mais valorizada, não ocorreu piora dos termos de troca da agropecuária com relação aos insumos com base importada (defensivos e fertilizantes). Esta constatação está em sintonia com a fundamentação teórica discutida por Helfand \& Rezende (2001) e Ferreira Filho (2000), quando consideram o efeito positivo advindo da redução do preço de insumos e conseguinte ganho de produtividade.

A sobrevalorização da taxa de câmbio ocorreu em um cenário no qual outras variáveis importantes estavam também sendo modificadas como os preços internacionais de commodities, a estabilização de preços e a abertura comercial com redução de barreiras tarifárias e não-tarifárias. Ademais, soma-se a questão da particularidade de cada setor quanto à relação com o mercado externo e com o mercado interno, definindo o seu grau de resposta aos condicionantes advindos das políticas macroeconômicas.

Como se pode ver, portanto, é difícil se avaliar o efeito isolado da taxa de câmbio sobre o agronegócio brasileiro, uma vez que há muitas variáveis envolvidas no processo. Este trabalho é uma tentativa, no sentido do isolamento do efeito da taxa de câmbio, considerando um contexto de relações intersetoriais e equilíbrio geral. 


\section{REVISÃO DE LITERATURA}

\subsection{Políticas macroeconômicas e a agropecuária}

As políticas públicas relacionadas com a agricultura ou agropecuária foram classificadas por Schultz (1978), quanto ao impacto sobre a produção. De acordo com aquele autor, primeiramente existem as políticas que são neutras com respeito ao custo de oportunidade da produção agropecuária. Em segundo lugar existem as políticas que sobrevalorizam a produção agropecuária. E por fim, existem as políticas que desvalorizam a produção agropecuária. Certamente as políticas macroeconômicas não se enquadram no primeiro grupo apontado por Schutz, sendo necessário verificar quais as particularidades que as levam a ser classificadas no segundo ou no terceiro grupo.

Vários autores (Schuh, 1983; Mamingi, 1996; Schiff \& Valdés, 1998) têm salientado a questão de que as políticas macroeconômicas adotadas pelos países em desenvolvimento (política fiscal, política monetária, política de comércio internacional, entre outras), têm gerado efeitos indiretos sobre a oferta agropecuária em importância superior aos efeitos diretos de políticas específicas. Schiff \& Valdés (1998) destacam que os efeitos indiretos sobre a agricultura, advêm de duas relações fundamentais:

- os preços relativos dos produtos agropecuários e não agropecuários;

- os preços relativos dos produtos tradables e non-tradables (taxa de câmbio real).

Analisando o efeito de políticas públicas sobre a agricultura brasileira durante os anos 90, Helfand \& Rezende (2000) enfatizam quatro aspectos a serem considerados: 
$1^{\circ}$ A política de substituição de importações como um marco da modificação da forma de tratamento da agricultura no país;

$2^{\circ}$ A política de liberalização comercial e desregulamentação de mercados, iniciada na década de 90;

$3^{\circ} \mathrm{O}$ impacto das políticas sobre o mercado de insumos e a produtividade agropecuária;

$4^{\circ}$ A questão da diferenciação do impacto sobre os diversos setores, conforme a região, destino da produção, tamanho de propriedades e períodos.

Baer (1995), Schiff \& Valdés (1998), Schuh (1998) e Helfand \& Rezende (2000) destacaram a questão da política de substituição de importação iniciada pelos países em desenvolvimento, após a segunda Guerra Mundial, como uma política de efeitos profundos sobre a agricultura destes países. Segundo os autores, a agricultura sofreu um processo de taxação indireta para favorecimento do setor industrial.

Schiff \& Valdés (1998) salientam que o setor industrial passou a ser visto, pelas escolas de pensamento econômico dos países em desenvolvimento, como o setor promotor do desenvolvimento. A agricultura por sua vez, era vista como um resquício colonial da relação comercial de venda de produtos básicos e compra de produtos manufaturados. Baer (1995) destaca que os responsáveis pela política econômica brasileira acreditavam que a industrialização visando a substituição de importações diminuiria a dependência em relação aos países industrializados.

As relações comerciais ainda eram avaliadas como de pouco potencial, de acordo com Schiff \& Valdés (1998); a linha de raciocínio dos economistas cepalinos, como Raul Prebish, considerava declinante os termos de troca em função da inelasticidade renda da demanda externa pelos produtos agropecuários dos países em desenvolvimento.

Internamente, a agricultura era vista como um setor que apresentava baixo índice de ligação com o restante da economia, especialmente a produção de "commodities" de exportação, o que justificava a sua colocação em segundo plano, dada a estratégia de promoção de crescimento econômico. Este fato foi plenamente vivenciado no Brasil a 
partir dos anos 50, como salienta Baer (1995), sobre a negligência dos tomadores de decisão no planejamento e adoção de políticas agrícolas.

Bautista et al. (1998) analisando as medidas associadas à política de industrialização visando a substituição de importação apontam as seguintes medidas adotadas pelos países que as praticaram:

- elevação das tarifas de importação de manufaturados e das taxas de exportação para os produtos agropecuários;

- restrições quantitativas à importação;

- sobrevalorização da taxa de câmbio;

- controle de preços agrícolas e subsídios de insumos.

Sem dúvida as políticas macroeconômicas, se diretamente não tinham a intenção de prejudicar a agricultura, indiretamente a negligenciaram durante a execução da política de substituição de importações. Por outro lado, os efeitos das políticas macroeconômicas geraram modificações importantes, como, por exemplo, a necessidade do aumento da escala de produção agropecuária para responder à crescente demanda urbana por alimentos. O velho paradigma da agricultura exportadora e geradora de divisas se modificava em função de alterações sócio-demográficas. Sobre este ponto, Baer (1995) chama atenção para um aspecto antes pouco discutido, a questão da produção de alimentos para abastecimento do mercado interno.

O processo de substituição de importações veio a se modificar a partir do início da década de 90, quando as políticas de abertura comercial se intensificaram.

Schiff \& Valdés (1998) argumentam que as políticas de ajuste estrutural dos países em desenvolvimento, praticadas a partir da década de 80 , buscavam corrigir os desequilíbrios macroeconômicos. O principal desequilíbrio era o crescente processo inflacionário, que se instalara na maioria dos países em desenvolvimento. Helfand \& Rezende (2000) chamam a atenção para os condicionantes do ambiente macroeconômico do fim dos anos 80 e início dos anos 90, sobre o setor agropecuário. Segundo os autores, as políticas que destituíram as práticas de substituição de importações, foram adotadas mais por uma necessidade de luta contra a hiperinflação, que por uma convicção da efetividade do novo modelo. 
As políticas macroeconômicas, como foi exposto, subordinaram as políticas agrícolas às suas necessidades. Neste sentido observou-se a questão da promoção do desenvolvimento através da valorização dos setores industriais. Segundo Gasques \& Conceição (2000), as transformações setoriais no sentido do crescimento econômico apresentam uma tendência de declínio da participação da agricultura na renda total do país.

Observou-se também o condicionamento das políticas agrícolas ao processo de combate à inflação, fato este ocorrido recentemente através do processo da âncora cambial, praticado nos primeiros anos do Plano Real. A crise fiscal do governo brasileiro foi outro aspecto macroeconômico que levou à modificação da política de crédito rural, como destacam Helfand \& Rezende (2000), da fonte de capital pública (tesouro nacional) para a fonte de capital privada. Além da alteração da fonte de capital para financiamento, a política monetária determinou a elevação da taxa de juros. Schuh (1998) chama a atenção para a alteração de 20 anos de taxas de juros negativas para um padrão positivo.

Crises mundiais, com efeitos diretos sobre a macroeconomia do país, também foram subordinadoras de políticas agrícolas, como por exemplo a do Proálcool. Schuh (1983) destaca que para enfrentar a crise causada pela elevação dos preços internacionais do petróleo, sem a adoção da desvalorização da moeda brasileira, o Proálcool foi uma opção no sentido da substituição de importações.

Helfand \& Rezende (2001), analisando o processo de modificação da política macroeconômica associado com a abertura comercial dos anos 90, destacam que a agricultura poderia se beneficiar da redução da proteção ao setor industrial. As exportações agropecuários também se beneficiariam, em função da eliminação de restrições e taxas ao comércio. O segmento agropecuária substituto de importação sofreria uma pressão maior de competição e o segmento non-tradable tenderia a obter uma compensação entre perdas e ganhos.

As variáveis macroeconômicas como a taxa de juros, a taxa de câmbio, os impostos as taxas de importação e exportação, a renda nacional, o nível de preços e de emprego, advêm de políticas fiscais, monetárias, sociais, de comércio exterior, que 
pouco consideram os efeitos sobre a atividade agropecuária em sua tomada de decisão. O mecanismo de tomada de decisão macroeconômica não faz parte do objetivo deste trabalho. No entanto, deve-se citar os trabalhos de Lamounier (1994) e Helfand (1999), como uma importante abordagem sobre o tema.

\subsection{Taxa de câmbio e os incentivos de preço na agropecuária}

Dentre as várias influências macroeconômicas sobre a agricultura, está a taxa de câmbio. A seguir serão apresentados os elementos que definem a forma de influência da taxa de câmbio sobre os mecanismos de incentivo de preço do setor agropecuário.

Bautista et al. (1998) argumentam que as políticas macroeconômicas influenciam a taxa de câmbio real, que por sua vez está associada com efeitos indiretos adversos ao setor agropecuário; chegando-se ao ponto dos efeitos indiretos serem superiores aos efeitos diretos das políticas específicas do setor.

Schuh (1974) foi um dos primeiros autores a enfatizar os efeitos da taxa de câmbio sobre a agricultura, segundo vários trabalhos realizados posteriormente à sua publicação, como por exemplo, Chambers \& Just (1981), Güzel \& Kulshreshtha (1995), Bautista et al. (1998) e Moss et al. (2001). O autor chamou a atenção para o fato de que a taxa de câmbio tinha sido sistematicamente omitida nas interpretações dos problemas de desenvolvimento e comércio dos Estados Unidos. Segundo ele, a taxa de câmbio é um importante influenciador da taxa de adoção de novas tecnologias, além de ser também importante fator de distribuição dos benefícios tecnológicos entre produtores e consumidores. Schuh (1974) conclui que um adequado entendimento do desempenho do setor agropecuário não pode existir sem a consideração da taxa de câmbio. Chambers

\& Just (1981) apontam a taxa de câmbio como importante transmissora de efeitos sobre a agricultura de políticas como a de abertura comercial. Sadorsky $(2000)^{3}$ apud Moss et al. (2001) afirma que os movimentos na taxa de câmbio podem ser importantes estímulos para a mudança de preços de commodities. Mamingi (1996) destaca que a 
taxa de câmbio chega a afetar a oferta agropecuária através dos seus efeitos sobre os preços relativos entre produtos agropecuários e não agropecuários, tradables e nontradables. Güzel \& Kulshrestha (1995) focam a questão da instabilidade da taxa de câmbio e os seus decorrentes efeitos sobre os custos de produção e a renda dos produtores rurais.

Mais recentemente Schuh (1998), analisando o efeito da política cambial do Plano Real sobre a agricultura brasileira, destaca os efeitos negativos da sobrevalorização, ressaltando que a agricultura, ao ser um importante setor de exportação, recebe uma taxação implícita nas exportações, ao mesmo tempo que as importações recebem um subsídio.

Uma consideração importante deve ser feita neste ponto, com relação à questão do efeito negativo da sobrevalorização sobre a agricultura brasileira durante o início do Plano Real. Como foi observado por Schuh (1998), os setores exportadores são implicitamente taxados com a sobrevaloriação. Ocorre, no entanto, que esse efeito não pode ser generalizado para toda a agropecuária, devendo-se contemplar as características das diversas atividades que compõem esse segmento da economia.

Schiff \& Valdés (1998) definem setor tradable como aquele relacionado com a produção de produtos substitutos de importados ou com a produção de produtos exportáveis; por outro lado, o setor non-tradable corresponde àquele cuja produção de uso doméstico. Os autores reforçam ainda a distinção entre os dois tipos de setores ou produtos, através do mecanismo de formação de preços de cada um; no caso dos produtos non-tradables, os preços se formam a partir do equilíbrio entre oferta e demanda doméstica; por outro lado, os preços dos produtos tradables são determinados por mercados mundiais, conjuntamente com a taxa de câmbio nominal, as taxas sobre o comércio e os subsídios.

A taxa de câmbio tem influência sobre os preços relativos de acordo com os setores da economia. Segundo Dornbusch (1987), há setores onde a mudança na taxa

\footnotetext{
${ }^{3}$ SADORSKY, P. The empirical relationship between energy futures prices and exchange rate. Energy Economics, v.22, p.253-266. 2000.
} 
causa significativa alteração dos preços relativos e há setores onde esse efeito pode ser negligenciado.

Helfand \& Rezende (2001) destacam que apesar da redução do viés contra a agricultura ocorrido com a política de abertura comercial dos anos 90, a sobrevalorização da taxa de câmbio não eliminou o viés contra os setores tradables agropecuários. Segundo os autores, o impacto resultante da combinação da abertura comercial com a sobrevalorização da moeda, acentua-se negativamente para os setores produtores de produtos agropecuários substitutos de importados, reduz os benefícios dos setores exportadores e gera uma leve pressão sobre os non-tradables. Como pode ser notado, a abordagem de Helfand \& Rezende (2001) contempla as particularidades dos setores segundo o grau de relação com o mercado internacional.

Os efeitos da taxa de câmbio sobre a agricultura, através dos incentivos de preço, podem ser observados de várias formas. Almeida \& Bacha (1998), analisando os efeitos da taxa de câmbio real sobre a balança comercial de produtos agropecuários e agroindustriais do Brasil, argumentam que as respostas aos estímulos de preços resultantes de variações na taxa de câmbio real, são defasadas e cumulativas. Destacam que a baixa elasticidade preço da oferta de produtos de exportação e da demanda de importações agropecuárias é uma explicação para a pouca efetividade de variações na taxa de câmbio real sobre o saldo comercial no curto prazo.

Mamingi (1996) destaca os impactos resultantes da sobrevalorização da moeda nacional e da proteção industrial sobre os preços relativos das commodities agrícolas e dos produtos não agropecuários non-tradables. Acrescenta, ainda neste contexto, a questão dos insumos agropecuários que para determinados segmentos do setor agropecuário dos países em desenvolvimento, são em grande parte importados. Desta forma, Mamingi (1996) e Moss et al. (2001) analisam que políticas de proteção das indústrias nacionais (via taxa de câmbio subvalorizada), resultam em aumento dos preços dos insumos importados gerando um mecanismo de taxação indireta; por outro lado, a sobrevalorização da taxa de câmbio reduz artificialmente os preços dos insumos importados, conduzindo, segundo o autor, à utilização ineficiente destes. A questão da ineficiência do uso dos insumos em função dos preços reduzidos pela sobrevalorização 
da moeda, não é uma unanimidade. Helfand \& Rezende (2001, p.12) consideraram positivo o efeito da abertura comercial associada com a sobrevalorização para o Brasil, uma vez que, observou-se substancial queda nos preços dos insumos como: tratores, equipamento de irrigação, fertilizantes e defensivos.

Enfatiza-se assim, a importância de se proceder a análise dos efeitos da taxa de câmbio de uma forma a se contemplar as particularidades setoriais, evitando-se chegar a resultados que não expressem a realidade, por estarem tratando a questão de forma agregada e generalizada.

Várias têm sido as formas de se abordar e estudar os efeitos dos movimentos da taxa de câmbio sobre o setor agropecuário e agroindustrial. Em linha geral, no entanto, pode-se dividir as abordagens em aquelas que utilizam o instrumental analítico de equilíbrio parcial e aquelas que se baseiam no equilíbrio geral. A seguir, as duas formas analíticas de estudo estarão sendo discutidas.

\subsection{Modelagem de equilíbrio parcial dos efeitos da taxa de câmbio}

O principal objetivo da análise de equilíbrio parcial que contemple o tratamento da taxa de câmbio é a quantificação das distorções do preço doméstico em relação ao preço externo. Bale \& Lutz (1981) apontam como causas das distorções de preços agrícolas os programas de suporte ao preço de produção, tarifas de importação, cotas de comércio, taxas de exportação e a sobrevalorização da taxa de câmbio.

$\mathrm{Na}$ abordagem analítica de equilíbrio parcial um primeiro aspecto a ser considerado refere-se à pressuposição da relação de preços em uma economia aberta. Dornbusch (1987) apresenta a chamada "lei do preço único" como uma das possíveis pressuposições. Segundo o autor, os preços dos produtos são geograficamente arbitrados e equalizados para diferentes localizações mediante o ajuste de tarifas e custos de transporte. A abordagem de equilíbrio parcial considerando a "Lei do preço único" é discutida por Mamingi (1996) como uma forma de verificação dos efeitos diretos da taxa de câmbio sobre os preços agrícolas. O efeito direto é capturado, segundo este autor, 
através da diferença proporcional entre o preço pago ao produtor e o preço internacional (ambos ajustados para a distribuição, estocagem, transporte e outros custos), como foi discutido por Dornbusch (1987). Diferenças negativas indicam taxação incidente sobre os produtores e diferenças positivas indicam subsídios aos mesmos. O mesmo conceito é aplicado no cálculo do coeficiente de proteção nominal, que é a razão entre os citados preços. Neste caso, valores menores que a unidade indicam que a agricultura está sendo taxada e valores superiores à unidade indicam subsídio à agricultura.

De acordo com Mamingi (1996), nos países em desenvolvimento a taxa de câmbio real sobrevalorizada gera os efeitos mais danosos sobre a agricultura. A sobrevalorização, de acordo com o autor, torna os produtos agropecuários menos competitivos que os importados e menos lucrativos na exportação.

$\mathrm{Na}$ ausência de políticas públicas que causem distorções, a "Lei do preço único" implica, segundo Bautista et al. (1998), que se o país for pequeno (em termos relativos ao comércio mundial) e houver substituição perfeita entre os bens produzidos domesticamente e os importados, uma mudança no preço do importado acarretará na mesma mudança do preço do produto doméstico. Por outro lado, se a produção doméstica destinada ao mercado externo for substituta perfeita da destinada ao mercado interno, o preço do produto doméstico será equivalente ao do mercado externo convertido em moeda local.

Um importante ponto a ser destacado, então, refere-se à pressuposição da substituição perfeita inerente à abordagem de distorções de preço contra a agricultura, originárias de políticas adotadas pelo governo. Aplicações do referido método são observadas em vários trabalhos como Bale \& Lutz (1981), Byerlee \& Sain (1986) e Taylor \& Phillips (1991). Constatou-se que a taxa de câmbio foi responsável por distorções de preços contra a agricultura em diversos países em desenvolvimento. Burnquist (1997) aplicou o conceito para verificação das distorções das políticas de liberalização comercial, constatando o grau de taxação implícita sobre soja, açúcar, arroz e trigo. Na mesma linha, Helfand \& Rezende (2001) baseados nas modificações nos preços internacionais, nos preços domésticos e na taxa de câmbio real, calcularam o resíduo que mede o grau de não aderência dos preços domésticos aos movimentos dos 
preços internacionais e da taxa de câmbio. Constatou-se que durante o período de 19901994 a 1995-1998, os preços agrícolas caíram dramaticamente, sendo a taxa de câmbio a principal força determinadora dos preços dos setores tratados, conforme pode ser notado nos dados da Tabela 2.

Tabela 2. Decomposição das mudanças no preço doméstico da agricultura entre o período de 1990-1994 e 1995-1998.

\begin{tabular}{|c|c|c|c|c|c|}
\hline Produto & & $\begin{array}{c}\text { Preço } \\
\text { doméstico }\end{array}$ & $\begin{array}{c}\text { Preço } \\
\text { inter- } \\
\text { nacional }\end{array}$ & $\begin{array}{c}\text { Taxa de } \\
\text { câmbio }\end{array}$ & Resíduo \\
\hline \multicolumn{6}{|l|}{ Substituto de importados } \\
\hline Feijão, milho, algodão e & arroz & $-17 \%$ & $4 \%$ & $-29 \%$ & $8 \%$ \\
\hline Trigo & & $-14 \%$ & $11 \%$ & $-29 \%$ & $7 \%$ \\
\hline Leite & & $-21 \%$ & $2 \%$ & $-29 \%$ & $6 \%$ \\
\hline \multicolumn{6}{|l|}{ Exportáveis } \\
\hline Cacau, laranja e soja & & $-16 \%$ & $8 \%$ & $-29 \%$ & $7 \%$ \\
\hline Café & & $41 \%$ & $49 \%$ & $-29 \%$ & $35 \%$ \\
\hline
\end{tabular}

\subsection{Modelagem de equilíbrio geral dos efeitos da taxa de câmbio}

A importância do setor externo para os países em desenvolvimento tem sido ponto fundamental nas aplicações dos modelos de equilíbrio geral. Melo (1988) destaca que mesmo em aplicações que não tenham como foco as relações externas, os resultados de impactos de políticas são decisivamente afetados por pressuposições acerca dessas relações. Esse é um ponto de vantagem da modelagem de equilíbrio geral, com relação ao equilíbrio parcial, uma vez que a alocação de recursos domésticos depende de fatores externos (Melo, 1988).

Devarajan et al. (1990) apontam que a simulação de políticas relacionadas com o mercado externo freqüentemente trabalha com:

1. depreciação da taxa de câmbio real para ajustamento aos termos de troca desvantajosos ou à redução do fluxo de capitais; 
2. redução na distorção causada por taxas, de forma a melhorar a eficiência e aumentar a competitividade internacional.

Bautista et al. (1998) destacam a necessidade de uma análise de equilíbrio geral de forma a se conseguir capturar todas as interações que determinam os impactos na rede de setores agropecuários e não agropecuários. A análise de viés em políticas públicas naturalmente implica em uma visão ampla das relações e inter-relações existente em uma economia. Güzel \& Kulshreshtha (1995) salientam que a análise de equilíbrio parcial não apresenta fundamentação adequada para o tratamento das possíveis mudanças macroeconômicas sobre o setor agropecuário, face o resto da economia. Segundo os autores, se as ligações com o resto da economia são importantes, a análise de equilíbrio geral é mais apropriada.

Ainda argumentando sobre as vantagens da análise de equilíbrio geral sobre a análise de equilíbrio parcial, Bautista et al. (1998) chamam a atenção para o pressuposto da substituição perfeita entre a produção doméstica e a importada, assim como, entre a produção destinada para exportação e a destinada para o mercado doméstico. Segundo eles, sob esta pressuposição não é possível o tratamento do comércio em duas vias ("cross hauling"), quando um mesmo setor exporta e importa. Neste mesmo sentido, Devarajan et al. (1990) argumentam que modelos baseados na "Lei do preço único", produzem extrema especialização na produção e deslocamentos não realistas nos preços relativos domésticos, em resposta às mudanças nos preços internacionais ou nas políticas de comércio.

De acordo com Melo (1988), a representação do setor externo em uma economia em desenvolvimento, baseada na pressuposição da produção doméstica de tradables ser perfeita substituta dos produtos externos, não é a mais apropriada. O autor salienta que, alternativamente, os modelos de equilíbrio geral têm utilizado a pressuposição de que os produtos domésticos substitutos dos importados são substitutos imperfeitos. Segundo Devarajan et al. (1990), evidências empíricas indicam que mudanças nos preços das importações e exportações, são somente parcialmente transmitidas para os preços dos bens domésticos. Da mesma forma, o mercado doméstico e o mercado externo 
representam possibilidades de transformação imperfeitas (Löfgren et al., 2001), refletindo uma dificuldade de alteração do destino da produção de uma forma abrupta. O termo substituição imperfeita normalmente é utilizado na literatura para se referir às relações externas, tanto de importação como de exportação, uma vez que, no segundo caso, assume-se que os produtos vendidos no mercado doméstico são substitutos imperfeitos daqueles vendidos no mercado externo. Sendo assim, deste ponto em diante o termo substituição imperfeita se referirá tanto para as importações como para as exportações.

Melo \& Robinson (1989) e Bautista et al. (1998), analisando a questão da substituição imperfeita, destacam que na análise de equilíbrio parcial, denominada por eles, modelo padrão de comércio neoclássico, apenas se distinguem os bens como tradables e non-tradables, não contemplando situações intermediárias e a intensidade de comercialização. Conforme as evidências obtidas na literatura, um importante aspecto que diferencia a análise de equilíbrio parcial da de equilíbrio geral, é a questão da substituição imperfeita entre produtos destinados ao mercado interno e externo e entre produtos domésticos e importados.

A preocupação fundamental dos modelos de análise do viés contra a agricultura, baseados no equilíbrio parcial, concentra-se sobre o incentivo de preços para a produção, não sendo capaz de captar as relações intersetoriais, a diferenciação de produto entre produção e demanda, e os efeitos induzidos das mudanças de preços sobre a taxa de câmbio de equilíbrio.

Uma abordagem mais realista, destacada por Devarajan et al. (1990), Decaluwé et al. (1996), Melo \& Robinson (1989), Bautista et al. (1998), entre outros autores, refere-se ao fato dos preços domésticos relacionarem-se com os internacionais, segundo as participações de exportações e importações de cada setor, e as elasticidades de transformação e substituição. Através da utilização de uma função CES (constant elasticity of substitution), que retrata a curva de possibilidades de consumo entre produtos domésticos e importados, e da CET (constant elasticity of transformation), que retrata a curva de possibilidades de transformação entre mercado doméstico e externo; captura-se a noção de que não é fácil modificar as participações tanto de exportações 
como de importações. A referida estrutura de equações CES e CET correspondem ao sistema proposto por Armington ${ }^{4}$.

Desta forma, como destacam Devarajan et al. (1990), para um dado valor de elasticidade de substituição e transformação, o preço doméstico será mais ligado ao preço externo quanto maior for a participação das exportações e importações. De acordo com Melo (1988), se os valores das elasticidades de substituição e transformação tenderem para o infinito, os preços domésticos estarão diretamente ligados aos preços internacionais, como estabelece a "Lei do preço único" nos modelos tradicionais de equilíbrio parcial.

Para se visualizar o tipo básico de tratamento do setor externo nos modelos de equilíbrio geral, Melo (1988) e Devarajan et al. (1990) apresentam um modelo simplificado para um setor apenas, mas que permite o entendimento dos elementos fundamentais desse tipo de análise (Figura 15).

\footnotetext{
${ }^{4}$ Armington, P. A theory of demand for products distinguished by place of production. IMF Staff Papers 16, 1969. p.159-176.
} 


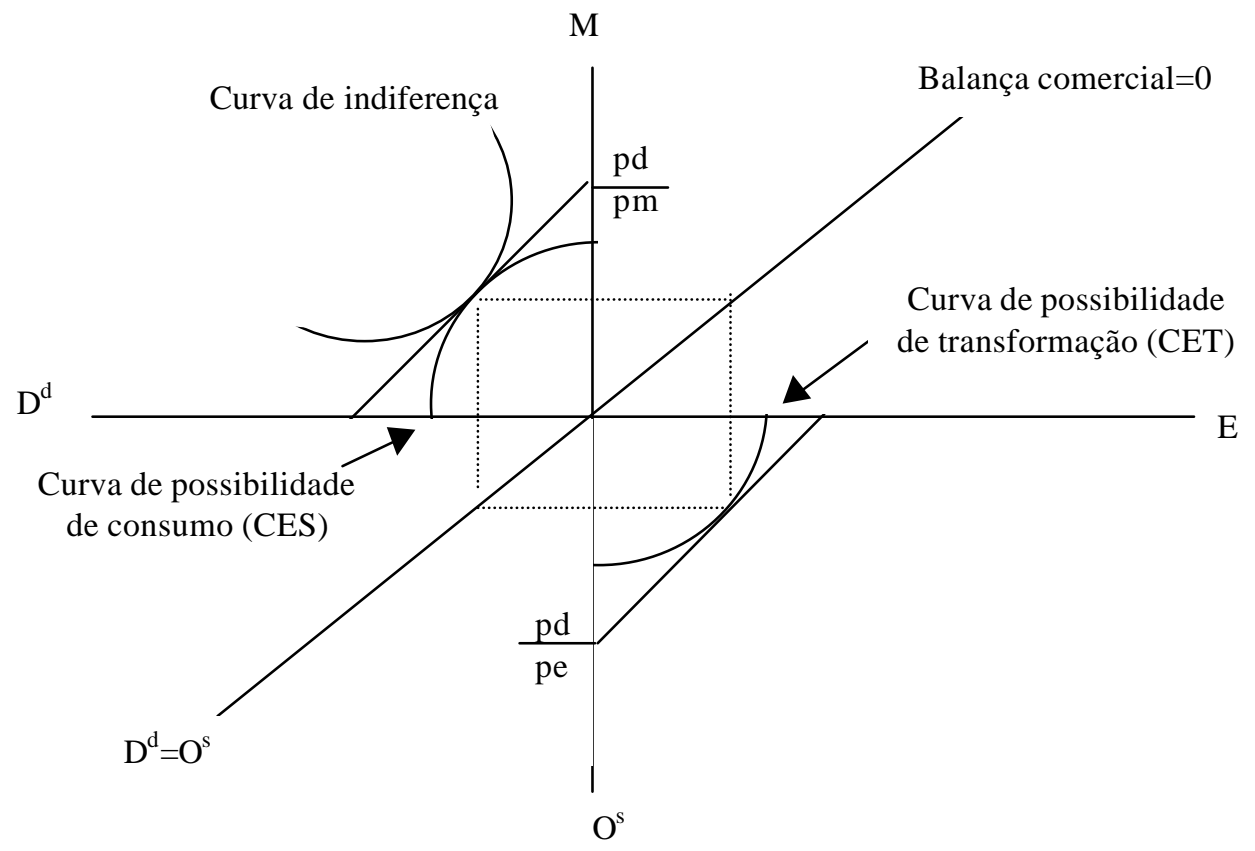

Figura 15 - Inter-relação entre o setor interno e o resto do mundo. (Fonte: Melo, 1988, p.474 e Devarajan et al.,1990, p.632)

Como pode ser observado na Figura 15, o modelo assume a existência de equilíbrio na balança comercial $(M=E)$ e no mercado interno (Demanda doméstica $D^{d}=$ Oferta doméstica $O^{\varsigma}$ ). A possibilidade de produção visando maximização de lucro a pleno emprego dos fatores é representada pela função CET. A possibilidade de consumo da população doméstica à mínimo custo é representada pela função CES. O equilíbrio ocorre quando a taxa marginal de transformação na produção se iguala à taxa marginal de substituição no consumo, ambas iguais à relação entre $\mathrm{p}^{\mathrm{d}} / \mathrm{p}^{\mathrm{e}} \mathrm{e} \mathrm{p}^{\mathrm{d}} / \mathrm{p}^{\mathrm{m}}$ (onde $\mathrm{p}^{\mathrm{d}}=$ preços domésticos, $\mathrm{p}^{\mathrm{e}}=$ preço das exportações $\mathrm{e} \mathrm{p}^{\mathrm{m}}=$ preço das importações).

$\mathrm{Na}$ formulação apresentada por Melo (1988) e Devarajan et al. (1990), a taxa de câmbio nominal funcionará como elemento equalizador para alterações na demanda e oferta domésticas se forem considerados fixos os preços externos e o equilíbrio comercial. 
Os preços internacionais, no modelo proposto por Melo (1988), são considerados exógenos, o que está associado à hipótese do país pequeno. Segundo Melo \& Robinson (1989), a hipótese do país pequeno estabelece que o país pode comprar e vender quantidades ilimitadas para o resto do mundo, sem afetar os termos de troca internacionais. De acordo com Löfgren et al. (2001), considerar os preços internacionais fixos implica em assumir que a oferta internacional de produtos para importação é infinitamente elástica, assim como, a demanda internacional por produtos domésticos de exportação. Esta pressuposição é considerada adequada principalmente quando se analisam políticas em países em desenvolvimento.

\subsubsection{Aplicações de equilíbrio geral}

Kilkenny \& Robinson (1990) discutem o aumento da amplitude de análise via a utilização de modelos de equilíbrio geral, pois além da avaliação dos impactos sobre o setor agropecuário em específico, pode-se avaliar os impactos sobre os demais setores, obtendo-se assim o comportamento de ajustamento da economia como um todo. Os autores destacam ainda a aplicabilidade dos modelos de equilíbrio geral por contemplarem os mercados de fatores, as contas públicas e os balanços macroeconômicos, especialmente para o caso do estudo de problemas agrícolas, que devem considerar as questões do inter-relacionamento com os demais segmentos da economia.

Os modelos de equilíbrio geral têm sido amplamente aplicados em análise de problemas de países desenvolvidos e países em desenvolvimento. Melo (1988) destaca que as aplicações nos países desenvolvidos têm sido mais voltadas para aspectos microeconômicos, onde procura-se estimar os impactos de estruturas tarifárias e políticas energéticas sobre o nível de bem estar. Por outro lado, o autor salienta também que nos países em desenvolvimento, os modelos de equilíbrio geral têm apresentado um campo mais amplo de aplicações, analisando questões macroeconômicas de médio e longo prazo e as mais tradicionais na área de microeconomia. Em levantamento 
realizado sobre trabalhos de equilíbrio geral aplicados em países em desenvolvimento, Decaluwé \& Martens (1988) afirmam que a maior preocupação está voltada para análise dos impactos de políticas internas de comércio exterior ou de mudanças na economia mundial, onde se busca um incremento da análise de equilíbrio parcial. Os autores destacam também aplicações no estudo de reformas tarifárias, subsídios, perda de bem estar interno vis-à-vis o bem estar externo, alternativas de financiamento dos gastos públicos e políticas cambiais.

Com relação as aplicações de longo prazo, Melo (1988) destaca as análises de impactos de estratégias de desenvolvimento sobre o nível de crescimento, alocação e exaustão de recursos. As aplicações de médio prazo contemplam a análise das relações rural-urbana (emigração, renda), do mercado de trabalho/desemprego, da distribuição de renda e do sistema de tributação.

Güzel \& Kulshreshtha (1995) analisando os efeitos da desvalorização da taxa de câmbio, com base no instrumental de equilíbrio geral, chegaram à conclusão que para a agricultura canadense, mudanças na taxa de câmbio real ocasionariam alteração dos preços relativos entre os setores agropecuários e não agropecuários. Por sua vez, a alteração de preços relativos gerou flutuações de preços, da produção setorial e da remuneração dos fatores. Frente à desvalorização da taxa de câmbio os autores constataram a melhoria dos termos de troca em favor da agricultura, acarretando em melhoria do retorno aos fatores de produção utilizados pela agricultura, que mobilizou fatores de outros setores da economia. Um importante aspecto a ser observado com relação aos resultados obtidos por Güzel \& Kulshreshtha (1995), refere-se ao perfil da agricultura canadense, que segundo os próprios autores, é orientada para o mercado externo, o que implica na obtenção de benefício dada uma desvalorização da taxa de câmbio.

Trabalhos que tenham manipulado a questão das relações externas através do instrumental de equilíbrio geral, são apresentados por Melo (1988), como exemplificação de tipos de abordagem e modelagem. Dentre eles pode-se destacar o de 
Dervis \& Robinson (1982) ${ }^{5}$ apud Melo (1988), que utilizaram um modelo com 15 setores para avaliar a taxa de câmbio de equilíbrio obtida se: a inflação interna se igualasse à externa; os empréstimos externos fossem iguais à taxa de crescimento do produto interno; os preços internacionais do petróleo aumentassem; e os preços de exportação dos concorrentes aumentassem menos que os preços internacionais.

Outro trabalho discutido por Melo (1988) trata da avaliação de políticas alternativas Chilenas com o resto do mundo, no qual verificou-se os efeitos da combinação da depreciação da taxa de câmbio real com o aumento do desemprego causado pela rigidez do salário real.

Najberg et al. (1995) apresentam para o Brasil um modelo de equilíbrio geral para análise de políticas econômicas relacionadas com modificações no câmbio e nas tarifas de comércio. Nas simulações realizadas, os autores verificaram o impacto da desvalorização em etapas sucessivas da taxa de câmbio e do aumento da alíquota do imposto de importação, sobre as transações correntes, exportações e importações,

\subsubsection{Modelos de equilíbrio geral e as particularidades da agropecuária}

No sentido da interligação da agropecuária com os demais segmentos, Kilkenny \& Robinson (1990) destacam a importância da mobilidade dos fatores entre os setores agropecuários e não agropecuários, na avaliação dos impactos de choques externos. O mercado de fatores pode sofrer impactos em intensidade diferentes se houver mobilidade ou não entre os setores agropecuários e não agropecuários. Para o caso dos setores agropecuários serem pequenos com relação aos demais, associado com a mobilidade dos fatores, os reflexos de choques no setor agropecuário, tendem a ser pequenos sobre o mercado de fatores da economia como um todo.

\footnotetext{
${ }^{5}$ Dervis, K. \& Robinson, S. A general equilibrium analysis of the foreign exchange crisis: the case of Turkey, Welwirtschaftliches Archiv, v.118, p.259-279. 1982.
} 
No modelo proposto por Kilkenny \& Robinson (1990), os cenários foram definidos considerando-se três diferentes graus de mobilidade dos fatores:

1. capital e trabalho não-móveis e fixos ao nível de pleno emprego, com a terra sendo ajustada endogenamente;

2. trabalho móvel, capital não-móvel ;

3. trabalho e capital móveis.

Em combinação com os graus de mobilidade dos fatores, considerou-se cenários macroeconômicos:

1. não alteração dos gastos governamentais e na balança comercial;

2. diminuição dos gastos públicos com programas agrícolas e manutenção da balança comercial;

3. redução do déficit orçamentário e externo.

Com os cenários estabelecidos, os autores analisaram os impactos da implantação da liberação comercial com base em duas situações :

1- eliminação de todos os programas internos de proteção (liberação unilateral do comércio);

2- eliminação de programas de suporte à agricultura em nível mundial (liberação multilateral).

Bautista \& Rosinson (1998) tratam a questão da mobilidade de fatores, considerando que estes (capital e trabalho) são móveis entre o grupo de setores agropecuários e entre o grupo de setores não agropecuários, não sendo permitida a mobilidade de fatores entre agropecuários e não agropecuários. Por outro lado, fazendo um paralelo com a abordagem de equilíbrio parcial, os autores destacam que ao impedir a mobilidade de fator entre os setores agropecuários e não agropecuários, cria-se um limite para o ajustamento de preços, o que aproxima os resultados da análise de equilíbrio parcial. Neste sentido, concordam que a mais apropriada medida de viés seria obtida na situação onde existe plena mobilidade dos fatores. 
Tipicamente as aplicações que têm uma abordagem mais específica sobre a agricultura, procuram tratar como fatores de produção: capital, trabalho e terra. Este último é considerado apenas para o setor agropecuário. Uma subdivisão do trabalho também é utilizada, considerando-se trabalho qualificado e não qualificado. Exemplos destas especificações mais detalhadas sobre os fatores de produção podem ser observados em Güzel \& Kulshreshtha (1995), Ferreira Filho (1997) e Bautista et al. (1998).

\subsubsection{Outros aspectos da modelagem de Equilíbrio Geral}

Thissen (1998a) destaca que a modelagem de equilíbrio geral tem sido apresentada na literatura com vários nomes: Transaction Value Models, Computable General Equilibrium Models, Applied General Equilibrium Models e SAM-based General Equilibrium Models.

Independente da nomenclatura utilizada, os modelos de equilíbrio geral, como destaca Thissen (1998a), correspondem a representações agregadas da economia, baseadas em fluxos de equilíbrio nos mercados de produto e fatores, em termos reais e nominais. A solução dos modelos de equilíbrio geral, como destacam Decaluwé \& Martens (1988), corresponde a um conjunto de preços, que diante do comportamento otimizante de consumidores e produtores, equilibra os mercados simultaneamente. Esse padrão de modelagem objetiva clarificar, a partir de uma estrutura transparente, os mecanismos pelos quais as políticas e choques exógenos afetam a economia em um contexto multisetorial.

Thissen (1998a) destaca ainda que os modelos de equilíbrio geral não objetivam elaborar previsões, mas sim dar uma indicação do sentido e amplitude dos efeitos. Uma forma de classificar os vários tipos de modelos de equilíbrio geral, baseia-se nas regras de fechamento adotadas e no tipo de técnica utilizada na determinação dos parâmetros 
do modelo. Quanto aos tipos de fechamento ${ }^{6}$, Thissen (1998a) apresenta os seguintes modelos:

- fechamento neoclássico: o nível de investimento se equilibra com o nível de poupança ao nível do pleno emprego.

- fechamento neo-keynesiano: o salário nominal é fixo (exógeno), enquanto que a produção permanece sendo determinada pela oferta de trabalho e capital.

- fechamento keynes/johansen: assume-se que o investimento (exógeno) pode estar abaixo do nível de pleno emprego. Neste caso deve-se endogeneizar os gastos públicos ou as taxas.

- fechamento de Kalecki ou estruturalista: assume-se que as empresas estão operando com excesso de capacidade (produção exógena e nível de emprego endógeno) e que o mercado tem forças oligopolísticas permitindo o estabelecimento do preço por markup (endógeno).

Para uma economia com comércio internacional, o fechamento deve contemplar também, de acordo com Decaluwé \& Martens (1988), o tratamento da taxa de câmbio, quanto a sua fixação ou flutuação em termos reais ou nominais. Os autores destacam que a escolha do tipo de fechamento é muito própria de critérios pessoais dos pesquisadores, geralmente não sendo observado argumentos convincentes das escolhas realizadas.

Sobre o tipo de técnica para determinação dos parâmetros do modelo, Thissen (1998a) comenta que a maioria das aplicações utiliza a técnica da calibração a partir de um ano base, em alternativa à estimativa via métodos econométricos. Segundo o autor, os modelos de equilíbrio geral com especificação econométrica, são raros em função da sua dificuldade de operacionalização.

O uso do método de calibração permite a fácil determinação dos parâmetros a partir de uma estrutura de dados referente a apenas um ano; ao mesmo tempo,

\footnotetext{
${ }^{6}$ Mecanismos de estabelecimento do equilíbrio em função da escolha das variáveis que serão consideradas exógenas e endógenas
} 
Melo (1988) e Thissen (1998a) destacam que significativas mudanças estruturais nos países em desenvolvimento tornam os dados históricos poucos efetivos na previsão de comportamentos futuros. A maior facilidade e praticidade do método de calibração, por outro lado, condiciona os modelos de equilíbrio geral à análise qualitativas e à limitações quanto as estimativas de confiabilidade dos resultados. Thissen (1998a) argumenta que a ausência de medidas estatísticas de confiabilidade pode ser contornada por análises sistemáticas de sensibilidade.

Sobre o pressuposto dos modelos de equilíbrio geral, Capros et al. (1990) destacam que a pressuposição de competição perfeita implica que todos os agentes são tomadores de preço e sempre existirá um conjunto de preços que igualará a demanda e oferta em todos os mercados. Concomitantemente, a pressuposição de homogeneidade implica em que apenas as alterações nos preços relativos terão efeitos sobre as condições de equilíbrio dos mercados. Por outro lado, Decaluwé \& Martens (1988) chamam a atenção para o fato de que a consideração do setor público nos modelos automaticamente introduz um grau de competição imperfeita através da fixação de preços, controle de quantidades e políticas de tributação e transferências.

Com relação aos mercados tratados nos modelos de equilíbrio geral, Capros et al. (1990) destacam que a representação numérica baseia-se em três mercados: o mercado de bens, o mercado de fatores e o mercado externo. Os preços associados a esses mercados são os preços agregados dos bens, os preços dos fatores e a taxa de câmbio.

Os agentes representados são os consumidores (famílias), os produtores (empresas) e o setor público. Com relação aos consumidores, Capros et al. (1990) destacam que os modelos de equilíbrio geral assumem que eles maximizam a utilidade dada a restrição orçamentária, determinando a demanda por bens e a oferta de trabalho. Quanto aos produtores (empresas), os modelos de equilíbrio geral assumem que estes buscam maximizar o lucro diante de retornos constantes de escala, gerando a demanda por fatores (capital e trabalho) e a oferta de produtos. 


\subsubsection{Limitações dos modelos de equilíbrio geral}

As limitações de um modelo de equilíbrio geral, segundo Harrison et al. (1993), podem ser baseadas em três características estimadas ou impostas a ele:

1. a estrutura de equilíbrio;

2. as formas funcionais usadas para representar gostos e tecnologia;

3. a magnitude dos elementos empíricos (elasticidades e parâmetros).

Thissen (1998b) argumenta que, do levantamento de um a década de modelos de equilíbrio geral aplicados ao Egito, apenas uma pequena parcela mostrou-se efetiva na orientação das políticas públicas. $\mathrm{O}$ autor destaca a necessidade dos modelos incorporarem novos elementos decorrentes das mudanças na economia real. Outra questão também salientada refere-se a geração de capacidade de realização de simulações de políticas de médio e longo prazo.

Sobre a calibração dos parâmetros utilizados nos modelos, Thissen (1998b) destaca a dificuldade de se avaliar quanto os parâmetros estimados se distanciam de seu valor real e se as variações observadas nas simulações são confiáveis ou não. $\mathrm{Na}$ tentativa de trabalhar com o tipo de problema apresentado por Thissen (1998b), Harrison et al. (1993) apresentam uma metodologia para verificação de quanto o modelo é robusto, dado o conjunto de parâmetros utilizados, em especial as estimativas de elasticidades adotadas. Segundo o autor, a solução de um modelo de equilíbrio geral é condicionada a uma certa estimativa de parâmetros, sobre a qual existe um determinado grau de incerteza, que implicará em um determinado grau de incerteza sobre a calibração obtida. Em linhas gerais, o autor conclui que uma dada inferência sobre uma política (simulação de um impacto exógeno) deve ser analisada quanto a sua robustez à variação dos parâmetros. Na metodologia proposta por Harrison et al. (1993), procura-se evitar a comumente observada avaliação ad hoc dos modelos, quando os pesquisadores adotam critérios próprios. 
A respeito das formas funcionais utilizadas nos modelos de equilíbrio geral, Devarajan et al. (1990) destacam que a formulação CES (constant elasticity of substitution) possue suas restrições, e sugerem a utilização, quando possível, de outras formas alternativas. Perroni \& Rutherford (1996) destacam a importância das propriedades globais das formas funcionais; a falta de regularidade, segundo os autores, pode causar falhas na solução de métodos numéricos. Por exemplo, as propriedades de terceira ordem da curvatura das funções, podem afetar drasticamente as estimativas de impactos sobre o bem estar. 


\section{METODOLOGIA}

Conforme foi apresentado nos capítulos anteriores, objetiva-se avaliar os impactos da taxa de câmbio sobre a agropecuária e a agroindústria (agronegócio), segundo a abordagem de equilíbrio geral, que possibilita o melhor tratamento dos interrelacionamentos desse setor com os demais setores da economia, tanto no aspecto da demanda intermediária produtos e fatores de produção, como da oferta de produtos para os mercados interno e externo. A modelagem de equilíbrio geral, pelo fato de possibilitar o tratamento do agronegócio inserido em um contexto econômico interno e externo, tem maior potencial de capturar um possível viés contra esse setor, a partir das interações e das resultantes alterações sobre preços relativos e variáveis quantitativas da economia.

Como pode ser observado na revisão de literatura, são várias as especificações possíveis dos modelos de equilíbrio geral, no tocante ao tratamento do mercado de fatores, do processo produtivo, do comportamento dos agentes econômicos, dos sistemas de impostos, do sistema financeiro, das relações externas e das linhas teóricas que orientam os fechamentos dos modelos. Neste sentido, o modelo a ser utilizado no presente trabalho deverá permitir o pleno tratamento dos dados, de forma a se atingir o objetivo da avaliação dos impactos da variação da taxa de câmbio, considerando com especial atenção o processo de sobrevalorização da moeda nacional, que ocorreu nos primeiros anos do Plano Real.

A seguir, serão apresentadas as especificações do modelo escolhido como base para o desenvolvimento do trabalho, procurando-se detalhar todos os critérios e procedimentos adotados, bem como as limitações, os pressupostos, a estimação de 
parâmetros e os critérios de decisão, cujas conseqüências sobre os resultados devem ser contempladas.

\subsection{O modelo}

A modelagem econômica é um assunto muito discutido, principalmente com relação à validação dos modelos adotados. A definição de validação, segundo West \& Jensen (1997), está relacionada à análise de quanto o modelo espelha a realidade perceptível. Os autores destacam ainda que a validação possui duas dimensões: interna e externa:

- interna - refere-se à verificação da adequação das linhas de causalidade e à lógica interna do modelo;

- externa - relaciona-se à análise do apropriado emprego do modelo nas áreas para as quais ele foi desenhado.

Associada à questão da validação, está a questão do tamanho do modelo. West \& Jensen (1997) destacam a existência de um tradeoff entre a simplicidade e a complexidade na modelagem. Segundo os autores, o incremento de complexidade de um modelo tem o preço da redução da capacidade de garantia da validade interna e externa.

Ainda com relação ao tamanho do modelo, tem-se a forma de implementação e obtenção da solução ótima. Brooke et al. (1996) argumentam que a solução de modelos não-lineares é ainda pouco robusta, muito trabalhosa e pouco automática, o que fortalece a utilização de modelos mais simples para a garantia da validade. Com relação à implementação por métodos de linearização, Horridge et al. (1998) também chamam a atenção para a complexidade da obtenção da solução, recomendando que se modifique pouco e se verifique muito.

Blaug (1999, p.128) destaca uma frase de Lionel Robbins apropriada para a discussão que se faz: 
"..Economia é a ciência do pensar em termos de modelos acoplada à arte de escolher modelos que são relevantes ao mundo contemporâneo..... O objetivo de um modelo é segregar os fatores semipermanentes ou relativamente constantes daqueles que são transitórios ou flutuantes..."

Diante do contexto apresentado no capítulo 1 (Introdução), que estabeleceu a necessidade da análise dos efeitos da taxa de câmbio sobre o agronegócio, deve-se realizar o exercício da identificação dos fatores semipermanentes e permanentes. Conforme foi destacado, a conjuntura dos anos 90, foi caracterizada por uma série de fatores que podem ser considerados permanentes desde então, quais sejam a modificação comercial, o início do processo de estabilização e a alteração da atuação econômica do poder público (principalmente do custeio de atividades para o caso da agropecuária). Ao mesmo tempo em que ocorriam modificações de caráter mais definitivo ou permanente, observaram-se também influências transitórias, como por exemplo, a flutuação dos preços internacionais de commodities de exportação e importação; e variações na taxa de crescimento do comércio mundial. Sendo assim, a verificação do impacto da taxa de câmbio sobre o agronegócio, em especial considerando a questão específica da sobrevalorização ocorrida durante os primeiros anos do Plano Real, implica em isolar esse feito frente aos demais acontecimentos da época, sem desconsiderar as modificações estruturais em ocorrência.

Observou-se a partir da revisão de literatura, que os modelos de equilíbrio parcial são mais focados nos preços e nas influências sobre estes da taxa de câmbio. Os aspectos estruturais, as relações setoriais e os processos de realocação de fatores de produção são contemplados na modelagem de equilíbrio geral, o que a torna mais apropriada ao propósito do presente trabalho. Uma vez estabelecido que o modelo deve ser de equilíbrio geral, passa-se a avaliar a questão do tradeoff entre simplicidade e complexidade da modelagem. Várias são as abordagens possíveis; em linhas gerais, elas podem variar segundo as especificações do setor externo, do encadeamento do setor produtivo, do detalhamento dos fatores de produção e do fechamento do modelo. 
Quanto ao setor externo, segundo os modelos consultados, as relações externas usualmente são modeladas com base na arquitetura Armington, que pressupõe a substituição imperfeita e a exogeneidade dos preços internacionais (país pequeno). Esta abordagem é muito utilizada e considerada uma das que mais contribuem para a validade do tratamento do setor externo. Exemplos de trabalhos que a utilizaram são encontrados em Decaluwé \& Martens (1988), Melo (1988), Melo \& Robinson (1989), Devarajan et al. (1990), Güzel \& Kulshreshtha (1995), Bautista et al. (1998), Decaluwé et al (1999a), Decaluwé et al. (1999b) e Löfgren et al. (2001). Se a pressuposição da exogeneidade dos preços internacionais for muito inadequada, quando o país possui significativa participação no comércio internacional, precisa-se incluir no modelo as equações de demanda externa pelos produtos nacionais de exportação e a equação de oferta externa de produtos importados.

Observando-se o histórico da participação do Brasil no comércio mundial, notase, a partir da Figura 16, que esta é muito pequena tanto para exportações como para importações, tendo este último setor apresentado significativo aumento a partir de 1992. Considerando a informação por setor, segundo os dados de Horta \& Souza (2000), apresentados na Tabela 3, nota-se que o Brasil apresentava no período de referência do modelo, participação pouco significativa na maioria dos setores exportadores. No agregado, o setor que mais participa no total de exportações mundiais é a Extrativa mineral, com 8,3\%, sendo, portanto, plausível aceitar a pressuposição do país pequeno. 


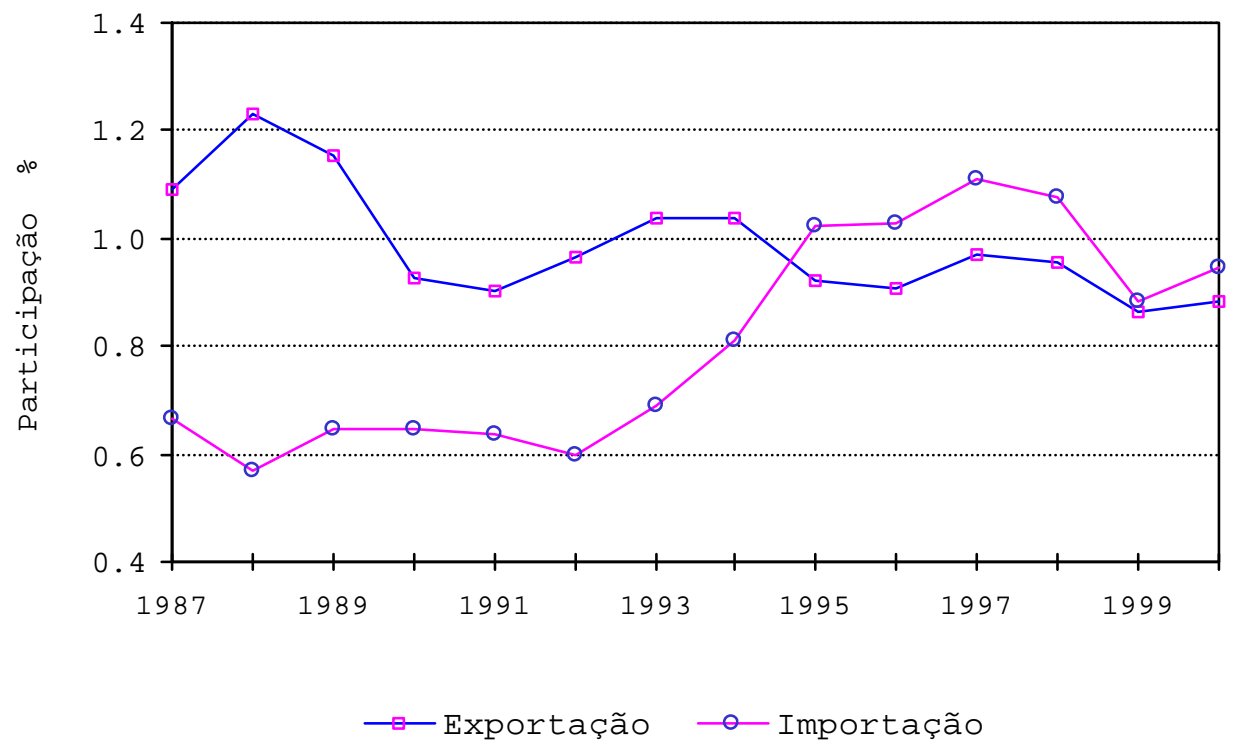

Figura 16 - Participação do Brasil nas exportações e importações mundiais no período de 1987 a 2000 (Fonte: Secretaria de Comércio Exterior - SECEX, 2001).

Tabela 3. Participação das exportações brasileiras no comércio mundial.

\begin{tabular}{lc}
\hline Setor & $\begin{array}{c}\text { Média } \\
\text { Agropecuária }\end{array}$ \\
\hline (\%)
\end{tabular}

Fonte: Horta \& Souza (2000) 
No caso específico das commodities agropecuárias mais tradicionais, como soja, café, açúcar, carne bovina e suco de laranja, que apresentam significativa participação nas exportações mundiais, poder-se-ia supor que a hipótese do país pequeno não seria válida. A esse respeito, Gonçalves (1997), Horta \& Souza (2000) e Castro \& Rossi Jr. (2000), através da estimação de equações de exportação, constataram que a hipótese do país pequeno é válida. Foram considerados como tomadores de preços no mercado mundial a soja, açúcar, carne bovina e suco de laranja. Apenas para o caso do café, constatou-se que as exportações brasileiras afetam o preço internacional, ou seja, a hipótese do país pequeno implicaria em algum grau de perda de sintonia com a realidade. Quando se trata o café dentro de um contexto da pressuposição do país pequeno, corre-se o risco de superestimar o valor das exportações, considerando-se, por exemplo, o aumento do volume exportado em resposta a uma desvalorização do câmbio. Se a exportação brasileira afeta o preço internacional, o aumento desta implicará na redução dos preços internacionais e consequentemente na redução do valor exportado.

Com relação ao encadeamento do setor produtivo, a adoção de um maior detalhamento do valor adicionado, bem como de funções mais complexas que possibilitem substituição entre os fatores de produção, implicaria na necessidade de informações adicionais acerca de elasticidades e critérios de separação. A maior rigidez do processo produtivo implica em uma análise de mais curto prazo, uma vez que as possibilidades de substituição estão restritas.

Sobre o fechamento do modelo, em função da necessidade de avaliação do ajustamento da economia frente a uma desvalorização do câmbio, seria necessário um fechamento onde um dos dois, o balanço de transações correntes ou a taxa de câmbio nominal, fosse exógeno. Se a taxa de câmbio for exógena a sua modificação implicará em ajustamento endógeno do balanço de transações correntes. Por outro lado, se o balanço de transações correntes for exógeno, a sua modificação implicará em um choque sobre a economia que se ajustará via modificação endógena da taxa de câmbio nominal.

Considerando ainda as necessidades de especificação de um modelo mais apropriado à problemática tratada neste trabalho, deve-se chamar a atenção para a 
questão da escolha do numéraire ${ }^{7}$ do modelo, denominada normalização. Sendo as variações reais da taxa de câmbio, fato gerador do impacto sobre os preços relativos tradables e non-tradables, a definição do numéraire deve contemplar a escolha de um índice de preços que resulte em uma adequada proxy da taxa de câmbio real. São vários os modelos disponíveis na literatura que contemplam o adequado tratamento do problema em questão. Os modelos selecionados como possíveis alternativas foram os de Ferreira Filho (1995), Güzel \& Kulshreshtha (1995), Decaluwé et al. (1996) e Bautista et al. (1998). Esses modelos são muito similares no tratamento do setor externo. As maiores diferenças ocorrem na especificação do valor adicionado, onde com exceção de Decaluwé et al. (1996), faz-se a subdivisão do trabalho e do capital.

No modelo de Decaluwé et al. (1996), o detalhamento das relações com o resto do mundo e as relações consideradas para o mercado interno, trata-se o tradeoff entre simplicidade e complexidade, tornando o modelo de Decaluwé apropriado aos objetivos do trabalho, bem como à capacidade de garantir a sua validação interna e externa. Sendo assim, diante da necessidade de priorização no sentido da simplicidade, de forma a se ganhar em maior domínio dos resultados a serem obtidos, escolheu-se esse modelo. Basicamente, este modelo espelha as relações de uma economia com o resto do mundo, considerando as possibilidades de consumo entre importados e nacionais, bem como as possibilidades de destino da produção para o mercado doméstico ou para o externo. Com relação à representação das relações de oferta e demanda, o modelo faz algumas simplificações ao considerar elasticidades de substituição unitárias.

Naturalmente, como destacam Brooke et al. (1996), a partir de uma base já testada e parametrizada, poder-se-á incluir outros aspectos não contemplados no modelo tratado, ampliando o seu potencial com o devido reconhecimento dos tradeoffs resultantes.

\footnotetext{
7 O termo "numéraire" corresponde a "numerário" na língua portuguesa, ou seja, estabelecer um referencial de valor para o modelo.
} 


\subsubsection{Fundamentos econômicos e pressupostos}

O modelo de Decaluwé et al. (1996) foi fundamentado em seis grupos de equações (produção, renda, demanda, comércio exterior, preços e condições de equilíbrio), as quais representam os fluxos correntes e condições de equilíbrio. Não há mercados de ativos, mercado monetário e mecanismos dinâmicos. Basicamente, representa uma economia aberta, com quatro agentes: famílias, empresas, governo e resto do mundo. As especificações das variáveis e parâmetros são apresentadas no Anexo $\mathrm{A}$ e as equações do modelo são apresentadas no Anexo B. Os valores dos parâmetros obtidos após a calibração são apresentados no Anexo D.

Os setores a serem tratados no modelo (contidos no conjunto $I$ ) são divididos em aquele que representa a administração pública (identificado com subíndice “ad”) e os que não representam a administração pública (definidos para o subconjunto de $I$ denominado $N$ ).

Visando discutir alguns pontos fundamentais da estrutura do modelo, serão apresentados os grupos de equações, como segue: produção, renda e poupança, demanda doméstica, comércio exterior e pressupostos, preços e normalização e condições de equilíbrio e fechamento.

\subsubsection{Produção}

As equações de 1 a 7 definem o sistema de produção no modelo, a especificação completa dos parâmetros, variáveis e equações é apresentada nos Anexos A e B.

$$
\begin{aligned}
& X_{i}^{s}=C I_{i} / i o_{i} \\
& C I_{i}=\left(i o_{i} \times V A_{i}\right) / v_{i} \\
& V A_{n}=a_{n} \times\left(L D_{n}^{\alpha_{n}} \times K_{n}^{\left(1-\alpha_{n}\right)}\right) \\
& L D_{n} \times \mathrm{W}=\left(P_{n}^{V A} \times V A_{n} \times \alpha_{n}\right) \\
& C I J_{i j}=a_{i j} \times C I_{j}
\end{aligned}
$$




$$
\begin{aligned}
V A_{a d} & =L_{a d} D \\
L_{a d} D & =\left(P_{a d} \times X_{a d} S-\sum_{j} P_{j}^{C} \times C I J_{i a d}\right) / W
\end{aligned}
$$

Onde:

Parâmetros:

$a_{n} \quad$ - Coeficiente de escala do valor adicionado

$\alpha_{n}$ - Participação do salário no valor adicionado

$a_{i j} \quad$ - Coeficiente técnico do consumo intermediário

$i o_{i}$ - Participação do consumo intermediário na produção

$v_{n} \quad$ - Participação do valor adicionado na produção

Variáveis:

$\mathrm{Cl}_{i}$ - Consumo intermediário total setorial - volume

$C / J_{i j}$ - Consumo intermediário setorial do bem $\mathrm{j}$ - volume

$K_{n} \quad$ - Estoque setorial de capital - volume (exógena)

$L D_{i} \quad$ - Demanda setorial por trabalho - volume

$P_{i}^{C} \quad$ - Preço do produto composto

$V A_{i}$ - Valor adicionado - volume

$W$ - Salário

$X_{i}^{S} \quad$ - Produção setorial do bem i - volume

Considerando que os produtores visam maximizar o lucro e que existe pleno emprego dos fatores (capital e trabalho), a produção doméstica é definida a partir de uma função Leontief, que caracteriza a utilização com proporções fixas entre consumo intermediário e valor adicionado, conforme pode ser observado nas equações 1 e 2.

No consumo intermediário, a participação de cada produto é fixa a partir dos coeficientes obtidos na calibração do modelo (equação 5). Na realidade, está sendo assumido que o padrão tecnológico observado no ano base não é alterado por choques em variáveis exógenas. O valor adicionado, composto pelos fatores capital e trabalho, é tratado no modelo através da função de produção Cobb-Douglas. O estoque de capital setorial em volume é fixo, e o trabalho é plenamente móvel entre os setores, com a oferta total fixa ou exógena. Sendo a função Cobb-Douglas linearmente homogênea, se observarão rendimentos constantes de escala para a produção setorial (equações 3 e 4).

A demanda por trabalho do setor Administração Pública é definida separadamente dos outros setores, uma vez que, o referido setor não utiliza capital, 
conforme se observa na equação 7. Sendo assim, o valor adicionado será igual à demanda por trabalho, de acordo com a equação 6 .

Dada a demanda setorial por capital e trabalho, o mercado de fatores se equilibrará quando a demanda total for igual à oferta total da economia. Os preços dos fatores irão se ajustar até que essa condição se satisfaça.

\subsubsection{Renda e poupança}

As equações de 8 a 19 geram os valores da renda e poupança dos agentes a partir dos parâmetros obtidos na calibração do modelo.

$$
\begin{aligned}
& Y_{M}=W \times \sum_{i} L_{i}^{D}+D I V+\lambda \times \sum_{n} R_{n} \times K_{n}+e \times T_{R M} \\
& R E=(1-\lambda) \times \sum_{n} R_{n} \times K_{n} \\
& D I V=t d v \times R E \\
& S_{M}=p m s \times Y D M \\
& Y D M=(1-t y) \times Y_{M} \\
& Y_{E}=R E+P I N D E X \times T_{G E} \\
& S_{E}=Y_{E}-t k \times R E-D I V-T_{E R} \\
& Y_{G}=t y \times Y_{M}+t k \times R E+\sum_{j} T X S_{i}+e \times T_{R G}+\sum_{n} T X M_{n}+ \\
& \quad \sum_{n} T X E_{n} \\
& T X S_{i}=t x_{i} \times P_{i} \times X_{i}^{S} \\
& T X M_{n}=t m_{n} \times e \times P_{n}{ }^{W M} \times M_{n} \\
& T X E_{n}=t e_{n} \times P_{n}^{E} \times E X_{n} \\
& S_{G}=Y_{G}-P I N D E X \times T_{G E}-C T_{G}
\end{aligned}
$$


Onde:

Parâmetros:

$\lambda \quad$ - Parcela da receita do capital destina às famílias

pms - Propensão marginal a poupar

$t d v \quad$ - Taxa de repasse de dividendos às famílias

$t e_{n} \quad-$ Imposto sobre exportação

$k \quad$ - Imposto de renda - empresas

$t m_{n} \quad$ - Imposto sobre importação

$t x_{\mathrm{i}} \quad$ - Imposto indireto

ty - Imposto de renda - famílias

Variáveis:

$C T_{G} \quad$ - Consumo público total - valor (exógena)

DIV - Dividendos das famílias - valor

$e \quad$ - Taxa de câmbio nominal (R $\$ / \mathrm{US} \$$ )

$E X_{n} \quad$ - Exportações FOB do bem n - volume

$P I N D E X$ - Índice geral de preços (exógena)

$P_{n}{ }^{E} \quad$ - preço local das exportações

$P_{n}{ }^{W M} \quad-$ Preço em moeda externa das importações (exógena)

$R E \quad$ - renda do capital das empresas

$R_{n} \quad$ - rendimento do capital

$\mathrm{Se} \quad$ - poupança das empresas - valor

$\mathrm{Sg} \quad$ - poupança do governo - valor

Sm - poupança das famílias - valor

Ter - Transferência das empresas p/ resto do mundo - valor (exógena)

Tge - Transferências públicas p/ empresas - volume (exógena)

Trg - Transferências do resto do mundo p/ governo - valor (exógena)

Trm - Transferências do resto do mundo p/ famílias - valor (exógena)

$T X E_{n} \quad$ - imposto de exportação - valor

$T X M_{n} \quad$ - Impostos de importação - valor

$T X S_{i} \quad$ - Impostos indiretos - valor

YDM - renda disponível das famílias - valor

Ye - renda das empresas - valor

Yg - renda do governo - valor

Ym - renda total famílias - valor

São calculados os valores de renda das famílias, empresas e governo através das equações 8, 13 e 15. Para o caso das famílias também se calcula a renda disponível, após o recolhimento do imposto de renda (equação 12). Outro conjunto de equações trata da poupança das famílias, empresas e governo, considerando para este caso os parâmetros da propensão marginal a poupar e o imposto de renda incidente sobre as 
empresas (equações 11, 14 e 19). Finalmente o último conjunto de equações trata da definição dos valores das taxas sobre a produção, sobre as importações e sobre as exportações (equações 16, 17 e 18).

\subsubsection{Demanda doméstica}

A demanda total doméstica corresponde à soma do consumo das famílias, dos gastos do governo, do investimento e do consumo intermediário, que são tratados no modelo através das equações 20 a 25 .

$$
\begin{aligned}
& C T M=Y D M-S M \\
& C M i=\beta_{i}{ }^{c} \times C T M / P_{i}{ }^{C} \\
& C G i=\beta_{i}{ }^{G} \times C T_{G} / P_{i}{ }^{C} \\
& C_{i}=C M_{i}+C G_{i} \\
& I N V_{i}=\beta_{i}{ }^{I} \times I T / P_{i}^{C} \\
& D I_{i}=\sum_{j} a_{i j} \times C I_{j}
\end{aligned}
$$

Onde:

Parâmetros:

$\beta_{i}^{c} \quad$ - Participação do bem i no consumo famílias

$\beta_{i}^{g} \quad$ - Participação do bem i no consumo governo

$\beta_{i}^{I}$ - Participação do bem i no investimento total

Variáveis:

CTM - consumo total das famílias - valor

$C M_{i} \quad$ - consumo das famílias do bem i - volume

$C_{i} \quad$ - consumo público do bem i - volume

$C_{i} \quad-$ consumo final do bem i - volume

$D I_{i} \quad$ - demanda intermediária do bem i - volume

$I N V_{i} \quad$ - investimento em bem i - volume

IT $\quad$ - Investimento total - valor

Com relação ao consumo total das famílias, definido através da equação 20, o modelo estabelece que este é função da renda disponível subtraída da quantidade 
poupada. Uma vez obtida a demanda total (ou consumo total) das famílias, se obtém o consumo com cada produto, baseado em um parâmetro fixo de participação $\left(\beta_{i}{ }^{c}\right)$, como pode ser observado nas equações 21. Os gastos totais do governo são tratados no modelo como sendo exógenos (variável $C T_{G}$ ), cabendo apenas a sua distribuição em volume entre os setores com base em um parâmetro de repartição de gastos públicos e no preço composto (equação 22). A soma do consumo das famílias e do governo por produto origina o consumo (ou demanda) final, de acordo com a equação 23.

A demanda de produto para investimento é obtida a partir da distribuição do investimento total segundo o parâmetro $\left(\beta_{i}{ }^{I}\right)$ e o preço composto (equação 24$)$.

Por fim, a demanda intermediária origina-se a partir do somatório da produção setorial destinada ao consumo intermediário, corresponde ao somatório das colunas de cada linha da matriz de consumo intermediário (equação 25).

\subsubsection{Comércio exterior e pressupostos}

O comércio exterior é tratado no modelo de acordo com a fundamentação teórica da substituição imperfeita, tanto do lado da importação como da exportação, e da consideração dos preços internacionais fixos (pressuposto do país pequeno). Para tal especificação são utilizadas as equações 26 a 31.

$$
\begin{aligned}
& X_{n}^{S}=b_{n}^{T} \times\left[{ }_{n}^{T} \times E X_{n}^{\left(\rho_{n}^{T}\right)}+\left(1-\delta_{n}^{T}\right) \times D_{n}^{\left(\rho_{n}^{T}\right)}\right]\left(\frac{1}{\rho_{n}^{T}}\right) \\
& E X_{n}=\left[\left(\frac{P_{n}^{E}}{P_{n}^{D}}\right)^{\sigma_{n}^{T}} \times\left(\frac{\left(1-\delta_{n}^{T}\right)}{\delta_{n}^{T}}\right)^{\sigma_{n}^{T}}\right] \times D_{n} \\
& Q_{n}=b_{n}^{S} \times\left[\delta_{n}^{S} \times M_{n}^{\left(-\rho_{n}^{S}\right)}+\left(1-\delta_{n}^{S}\right) \times D_{n}^{\left(-\rho_{n}^{S}\right)}\right]\left(\frac{-1}{\rho_{n}^{S}}\right) \\
& M_{n}=\left[\left(\frac{\delta_{n}^{S}}{\left(1-\delta_{n}^{S}\right.}\right)^{\sigma_{n}^{S}} \times\left(\frac{P_{n}^{D}}{P_{n}^{M}}\right)^{\sigma_{n}^{S}}\right] \times D_{n}
\end{aligned}
$$


$X_{\mathrm{ad}}{ }^{S}=Q_{\mathrm{ad}}-\left(M_{\mathrm{ad}}+T X M_{\mathrm{ad}}\right)-T X S_{\mathrm{ad}}+E X_{\mathrm{ad}}$

$B C=\sum_{n} P_{n}{ }^{W N} \times M_{n}+(1 / e) \times T_{E R}-\sum_{n} P_{n}{ }^{W E} \times E X_{n}-T_{R M}-T_{R G}$

Onde:

Parâmetros:

$b_{n}{ }^{T}$ - Parâmetro de dimensão da função CET

$\delta_{\mathrm{n}}{ }^{T} \quad$ - Parâmetro de proporção da função CET

$\rho_{n}{ }^{T}$ - Expoente da função CET

$\sigma_{\mathrm{n}}{ }^{T} \quad-$ Elasticidade de transformação

$b_{n}{ }^{S}$ - Parâmetro de dimensão da função Armington (CES)

$\delta_{n}{ }^{S}$ - Parâmetro de proporção da função Armington (CES)

$\rho_{n}{ }^{S} \quad$ - Expoente da função Armington (CES)

$\sigma_{n}^{S} \quad-$ Elasticidade de substituição

Variáveis:

$B C$ - balanço de transações correntes - valor em divisas (exógena)

$D_{n} \quad$ - demanda interna de produto doméstico - volume

$M_{n} \quad$ - importações CIF - volume

$P_{n}{ }^{D} \quad$ - preço da produção doméstica

$P_{n}^{M} \quad$ - preço local das importações

$P_{n}^{W E} \quad-$ preço em moeda externa das exportações (exógena)

$Q_{i} \quad$ - oferta interna do produto composto - volume

A produção doméstica tem a possibilidade de ser destinada para mercado interno e/ou para o mercado externo. O modelo utiliza a função CET (constant elasticity of transformation), ou seja, dada uma determinada relação entre preço de exportados e preço doméstico, mais a elasticidade de transformação, determina-se quanto da produção será destinada para o mercado interno e para o mercado externo, conforme é especificado pelas equações 26 e 27.

A oferta doméstica composta é formada pela parcela da produção doméstica destinada para o mercado doméstico e pela importação. O modelo trata a questão através da função CES, tendo como base a relação entre preço doméstico e preço de importados, mais a elasticidade de substituição entre domésticos e importados. As equações 28 e 29 estabelecem as relações descritas. Devarajan et al. (1990) comentam que as funções CES e CET capturam razoavelmente a noção de que não é tão automático modificar as participações nos mercados de importação e de exportação. Em outras 
palavras, assume-se o conceito de substituição imperfeita, uma pressuposição mais realista que define importações e exportações dependentes dos preços relativos, como destacam Decaluwé \& Martens (1988) e Melo \& Robinson (1989).

Através da equação 30 , estabelece-se no modelo o equilíbrio entre oferta (produção doméstica) e demanda pelo setor Administração Pública.

Finalizando o conjunto de equações que trata do comércio exterior, tem-se a equação 31 que define o balanço de transações correntes em moeda externa. De acordo com a definição, o déficit no $\mathrm{BC}$ está associado a um valor positivo e o superávit a um valor negativo.

\subsubsection{Preços e normalização}

Uma das vantagens da abordagem de equilíbrio geral sobre a de equilíbrio parcial é a especificação de vários preços, que buscam captar os impactos de uma forma mais apurada. As equações 32 a 39 estabelecem as relações e definições dos preços do modelo.

$$
\begin{aligned}
& P_{\mathrm{n}} \times\left(1+t x_{\mathrm{n}}\right)=\left(D_{\mathrm{n}} / X_{\mathrm{n}}^{S}\right) \times P_{\mathrm{n}}{ }^{D}+\left(E X_{\mathrm{n}} / X_{\mathrm{n}}{ }^{S}\right) \times P_{\mathrm{n}}{ }^{E} \\
& P_{\mathrm{n}}{ }^{V A}=\left(P_{\mathrm{n}} \times X_{\mathrm{n}}{ }^{S}-\sum_{j} P_{\mathrm{j}}{ }^{C} \times C I J_{\mathrm{jn}}\right) / V A_{\mathrm{n}} \\
& P_{\mathrm{n}}{ }^{M}=\left(1+t m_{\mathrm{n}}\right) \times e \times P_{\mathrm{n}}{ }^{W M} \\
& P_{\mathrm{n}}{ }^{E}=e \times P_{\mathrm{n}}{ }^{W E} /(1+t e m) \\
& P_{\mathrm{n}}{ }^{C}=\left(D_{\mathrm{n}} / Q_{\mathrm{n}}\right) \times P_{\mathrm{n}}{ }^{D}+\left(M_{\mathrm{n}} / Q_{\mathrm{n}}\right) \times P_{\mathrm{n}}{ }^{M} \\
& P_{\mathrm{ad}}{ }^{C}=P_{\mathrm{ad}} \\
& R_{\mathrm{n}}=\left(P_{\mathrm{n}}{ }^{V A} \times V A_{\mathrm{n}}-W \times L_{\mathrm{n}}{ }^{D}\right) / K_{\mathrm{n}} \\
& P I N D E X=\sum_{i} \beta_{\mathrm{i}}^{X} \times P_{\mathrm{i}}
\end{aligned}
$$

Onde:

Parâmetro:

$\beta_{i}^{X} \quad$ - Participação do bem i na produção total 
Variável:

$P_{i}$ $P_{n}^{V A}$

- Preço para a produção do setor

- Preço do valor adicionado

Nas equações 34 e 35, se define a conversão do preço internacional dos produtos exportados e importados para o correspondente valor em moeda nacional. Sendo a taxa de câmbio correspondente ao valor da moeda estrangeira em moeda nacional, esta deve multiplicar o preço internacional. Na conversão ainda considera-se a incidência de taxas de importação e exportação.

O preço para a produção ou o recebido pelos produtores do setor $i(P i)$, quando acrescido dos impostos indiretos $(t x)$ deve-se igualar à média ponderada entre o preço doméstico e o preço local das exportações (equação 32). A ponderação é realizada respectivamente com base na porcentagem da produção destinada ao mercado doméstico $\left(D_{n} / X_{n}{ }^{S}\right)$ e na porcentagem da produção destinada ao mercado externo $\left(E X_{n} / X_{n}{ }^{S}\right)$. A mesma especificação, realizada para o cálculo do preço para a produção do setor, é utilizada no cálculo do preço do produto composto ${ }^{8}$. Preço este que efetivamente corresponde ao preço pago pelas famílias, governo e empresas, ao consumirem produtos compostos (equação 36). A média entre o preço doméstico e o preço local dos importados é ponderada de acordo com a participação da produção local na oferta composta total $\left(D_{n} / Q_{n}\right)$ e na participação da importação na oferta total composta $\left(M_{n} / Q_{n}\right)$.

A definição do preço do valor adicionado, obtida a partir da equação 33, parte do princípio segundo o qual o valor adicionado corresponde à diferença entre o montante recebido pela produção $\left(P_{\mathrm{n}} \times X_{\mathrm{n}}{ }^{S}\right)$ e o seu respectivo custo $\left(\sum_{j} P_{\mathrm{j}}^{C} \times C I J_{\text {jn }}\right)$. No mesmo estilo é definido o preço do capital (equação 38), quando se subtrai do total de valor adicionado $\left(P_{\mathrm{n}}{ }^{V A} \times V A_{\mathrm{n}}\right)$ o montante de valor adicionado pelo trabalho $\left(W \times L_{\mathrm{n}}{ }^{D}\right)$. O setor Administração pública não apresenta distinção entre o preço composto $\left(P_{\mathrm{ad}}{ }^{C}\right)$ e o preço para a produção $\left(P_{\mathrm{ad}}\right)$, de acordo com o que é estabelecido na equação 37 . As

\footnotetext{
${ }^{8}$ Produto composto corresponde à soma dos produtos produzidos localmente mais os importados.
} 
relações e a direção de transmissão de choques entre os preços do modelo podem ser observadas na Figura 17.

Cabe neste ponto fazer uma observação sobre o processo de normalização. De acordo com Dervis et al. (1982), a normalização nada mais é que a escolha do numéraire do modelo. Na solução base, obtida após a calibração do modelo, as variáveis em volume, serão obtidas a partir da divisão pelos seus respectivos preços, sendo estes todos expressos em termos do numéraire, tornando a economia similar a um sistema de trocas. Nessa solução base, ocorrerá que as variáveis em volume serão iguais às respectivas variáveis em valor, o que se modificará com um choque exógeno, que alterará os preços e consequentemente diferenciará as variáveis em volume das em valor.

$\mathrm{Na}$ equação 39 define-se o índice geral de preços, que será o numéraire do modelo, ou seja, todos os preços serão expressos em termos do índice de preços para a produção. A definição do numéraire ocorre quando a variável índice de preços é exógena, ou seja, um choque que altere os preços relativos do modelo deverá ser absorvido, mantendo-se o índice geral de preços igual a 1.

Chamando a atenção para o preço do salário $(W)$, destaca-se que esse valor é um índice único para todos os setores, ou seja, a mobilidade do trabalho ocorre sem que se altere o salário entre os setores. 


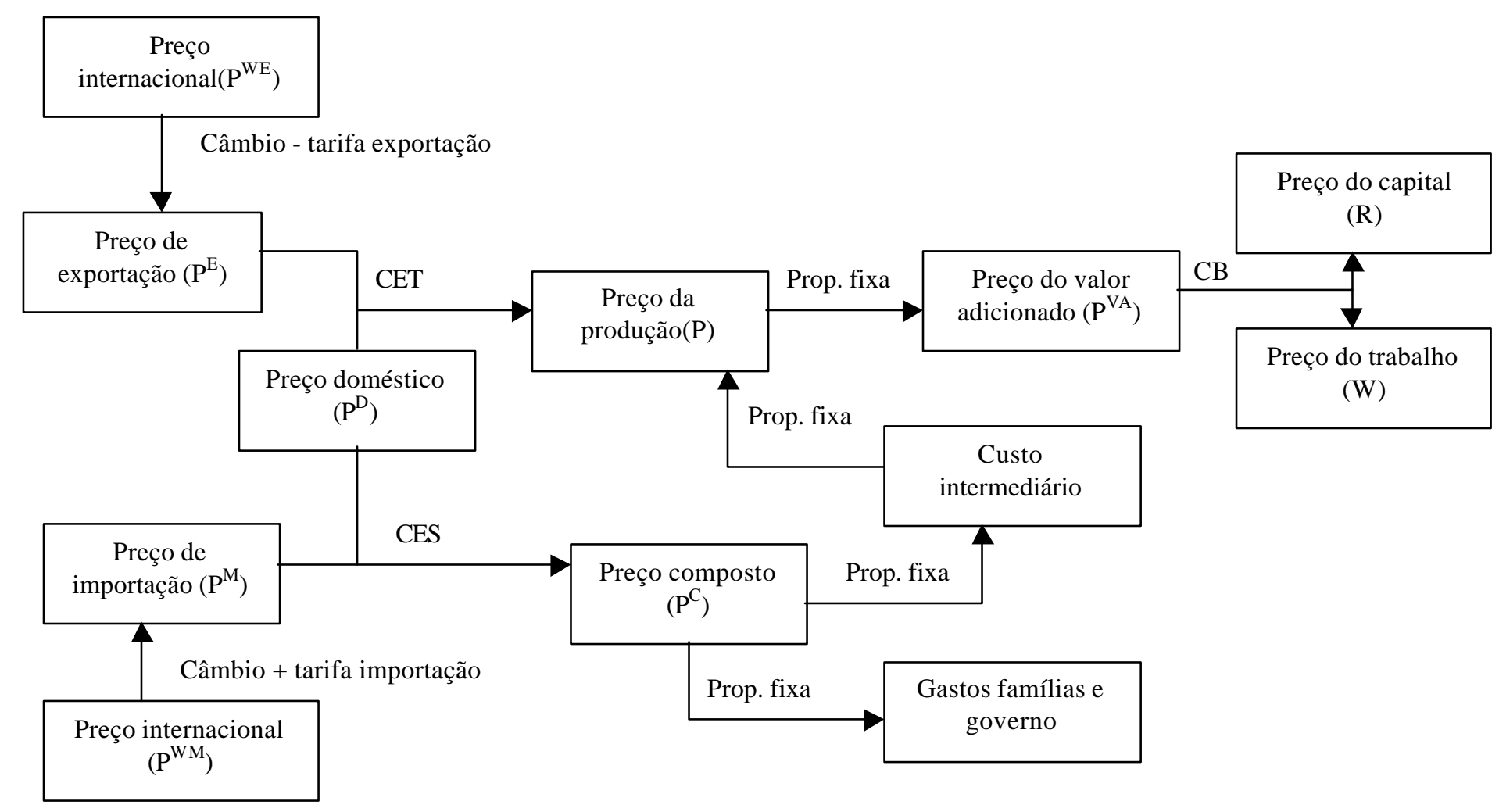

Figura 17 - Mecanismo de transmissão de preços. 
Dentro do contexto de preços, um importante elemento é a taxa de câmbio nominal. Como destacam Dervis et al. (1982) esta é simplesmente o número pelo qual os preços internacionais devem ser multiplicados para se obter o equivalente em moeda nacional. Melo \& Robinson (1989) salientam que a taxa de câmbio nominal é apenas um fator de conversão da moeda externa em seu equivalente em moeda nacional. Destaca-se que a taxa de câmbio referida no modelo (e) é a taxa nominal, sendo a taxa de câmbio real, aquela que relaciona o preço de produtos tradables em relação aos nontradables, depende da definição do numéraire. Segundo Devarajan et al. (1990), se o numéraire do modelo for o índice de preço doméstico a taxa de câmbio nominal corresponde à real, no sentido da teoria neoclássica, ou seja, o preço relativo dos tradables em relação aos non-tradables. Se for estabelecido outro numéraire para o modelo, a taxa de câmbio passa a ser uma função monotônica da taxa de câmbio real.

Segundo o que Melo \& Robinson (1989) argumentam, a utilização do índice geral de preços para a produção, é uma das alternativas de ponderação para obtenção de uma "proxy" do índice de preços domésticos. Os autores destacam a dificuldade da escolha do ponderador para o cálculo do índice de preços domésticos para a representação da taxa de câmbio real. Segundo ele, tipicamente o índice de preço doméstico tem como proxy os dados publicados como o índice de preços ao consumidor ou o deflator implícito do PIB, os quais incluem produtos tradables. Como já foi apresentado utilizou-se como numeráire o índice de preços para a produção.

\subsubsection{Condições de equilíbrio e fechamento}

Devem ser respeitadas as condições de equilíbrio conforme as equações 40 a 44 .

$$
\begin{aligned}
& E T T=\Sigma_{\mathrm{i}} P_{\mathrm{i}}^{C} \times E S T_{\mathrm{i}} \\
& I T=S_{\mathrm{M}}+S_{\mathrm{E}}+S_{\mathrm{G}}+e \times B C-E T T \\
& Q_{\mathrm{i}}=C_{\mathrm{i}}+D I_{\mathrm{i}}+I N V_{\mathrm{i}}+E S T_{\mathrm{i}}
\end{aligned}
$$




$$
\begin{aligned}
& L^{S}=\sum_{i} L_{\mathrm{i}}^{D} \\
& L E O N=Q_{\mathrm{SAD}}-C_{\mathrm{SAD}}-D I_{\mathrm{SAD}}-I N V_{\mathrm{SAD}}-E S T_{\mathrm{SAD}}
\end{aligned}
$$

Onde:

Variável:

$E S T_{i}$ - Estoque em bem - volume (exógena)

ETT - Estoque total - valor

LEON - Variável de controle da identidade de Walras - volume

$L^{S} \quad$ - Oferta total de trabalho - volume (exógena)

O fechamento proposto por Decaluwé et al. (1996), caracteriza-se como do tipo neoclássico, uma vez que, poupança e investimento devem se igualar no ponto de equilíbrio, conforme estabelece a equação 41 . Sendo assim, o investimento será igual à soma das poupanças das famílias $\left(S_{M}\right)$, das empresas $\left(S_{E}\right)$, do governo $\left(S_{G}\right)$ e do resto do mundo ( $e B C$ - saldo das transações correntes em moeda nacional).

Foi necessária a inclusão de uma equação adicional, a de número 40, em função das particularidades dos dados disponíveis na matriz Insumo-Produto do Fundação Instituto Brasileiro de Geografia e Estatística - IBGE (1995b). Nestas matrizes aparece a chamada variação de estoques, que não era tratada inicialmente pelo modelo de Decaluwé et al. (1996). Desta forma, a nova equação (40) trata a variação de estoques fixa em volume para cada setor; permitindo a sua alteração em valor resultante da variação dos preços dos produtos compostos. A alteração do estoque setorial em valor será absorvida pela variável estoque total (ETT).

A equação 42 trata da absorção doméstica da oferta composta. A oferta composta do produto $i$ deve ser igual à soma do consumo das famílias e governo $\left(C_{i}\right)$, do consumo intermediário $\left(D I_{i}\right)$, do investimento $\left(I N V_{i}\right)$ e da variação de estoque $\left(E S T_{i}\right)$, sendo todas as variáveis definidas em volume (valor gasto/preço do produto composto).

Na equação 43 define-se que a oferta de trabalho total $\left(L^{S}\right)$, obtida a partir da demanda por trabalho da solução básica do modelo, é uma variável exógena que deve 
ser totalmente absorvida pela demanda setorial por trabalho $\left(L_{i}{ }^{D}\right)$. Assume-se então a existência de pleno emprego e a mobilidade total do trabalho entre os diferentes setores.

Finalmente na equação 44, realiza-se a verificação da lei de Walras, que implica no equilíbrio simultâneo de todos os setores, ou seja, quando $n-1$ setores estiverem em equilíbrio o $n$-ésimo setor também estará. O valor da variável LEON deve tender à zero na solução ótima do modelo.

Ainda sobre o fechamento do modelo, são definidas como variáveis exógenas o

preço em moeda externa das exportações e importações $\left(P_{n}{ }^{W E}\right.$ e $\left.P_{n}{ }^{W M}\right)$, o balanço de transações correntes $(B C)$, as transferências $\left(T_{g e}, T_{r g}, T_{m}, T_{e r}\right)$, o estoque setorial de capital $\left(K_{n}\right)$, o estoque de produto em volume $\left(E S T_{i}\right)$, a oferta total de trabalho $\left(L^{S}\right)$ e o ínidice de preços para a produção $(P I N D E X)$ e o consumo público total $\left(C T_{G}\right)$.

\subsubsection{Visualização geral do modelo}

Para se visualizar a integração entre os grupos de equações descritos anteriormente, elaborou-se o esquema apresentado na Figura 18. Nele estão integrados o processo produtivo, o setor externo, a demanda e oferta de produtos compostos. Destaca-se que a demanda local (consumo das famílias, consumo intermediário, gastos do governo, investimentos e estoques) é suprida por produtos compostos. Uma parcela da oferta composta é representada pela produção doméstica que não foi exportada.

\subsubsection{Definição dos valores das elasticidades}

As elasticidades constituem, como destacam Devarajan et al. (1990), elementos determinantes do ponto de equilíbrio para o caso da arquitetura do modelo proposto. 


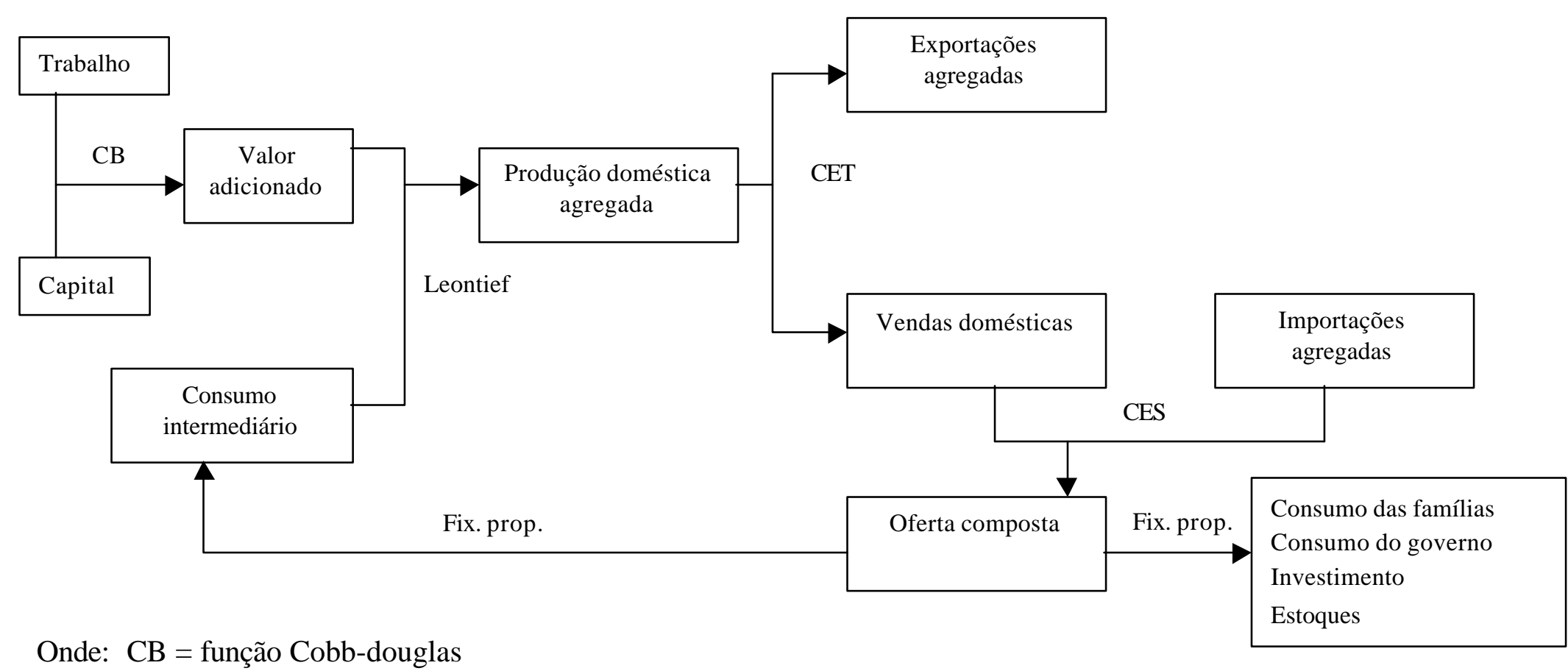

$\mathrm{CES}=$ Constant elasticity of substitution

$\mathrm{CET}=$ Constant elasticity of transformation

Fix. prop.. = proporções fixas

Figura 18 - Representação do fluxo de produtos e equações que definem as relações. 
Deve-se definir um determinado critério para a adoção dos valores de elasticidades de substituição e de transformação. Considerando que a elasticidade de substituição mede a variação do volume de importação em função da alteração dos preços relativos (preço de importados em moeda nacional / preço doméstico) e a elasticidade de transformação mede a variação do volume de exportações em função da alteração dos preços relativos (preço de exportações em moeda nacional / preço doméstico), com base nos trabalhos de Martner (1992), Castro \& Cavalcanti (1997), Cavalcanti \& Ribeiro (1998), Carvalho \& Parente (1999) e Carvalho \& De Negri (2000), foi possível definir os valores específicos para cada setor a partir das equações de importação e exportação estimadas pelos autores.

$\mathrm{Na}$ Tabela 4 apresenta-se o valor das elasticidades de substituição e transformação calculadas a partir dos trabalhos anteriormente citados. As elasticidades de substituição são em sua maioria superiores à unidade, indicando que as importações respondem mais elasticamente às alterações nos preços relativos. À primeira vista, esses valores podem destoar da dependência por importados de determinados setores brasileiros. Acredita-se que apenas no tratamento específico por produto, seja possível identificar determinados segmentos com dependência acentuada, como é o caso do setor de extrativa mineral, que basicamente importa combustíveis, produto para o qual o país apresenta uma dependência de natureza não tecnológica, mas sim de disponibilidade do recurso. Quando se trata a elasticidade de substituição por setor, a dependência por alguns produtos específicos fica diluída na média dos produtos importados pelo setor.

Por outro lado, no caso das elasticidades de transformação, os valores menores que a unidade, indicam uma reação de forma inelástica à variação dos preços relativos, o que é tipicamente observado para os setores produtores de produtos básicos ou semimanufaturados, dentre eles os setores agropecuários. Nos setores manufatureiros, os valores utilizados são maiores que a unidade, indicando um comportamento mais elástico das exportações à alteração dos preços relativos. 
Tabela 4. Valores adotados para as elasticidades de substituição e transformação entre mercado doméstico e externo.

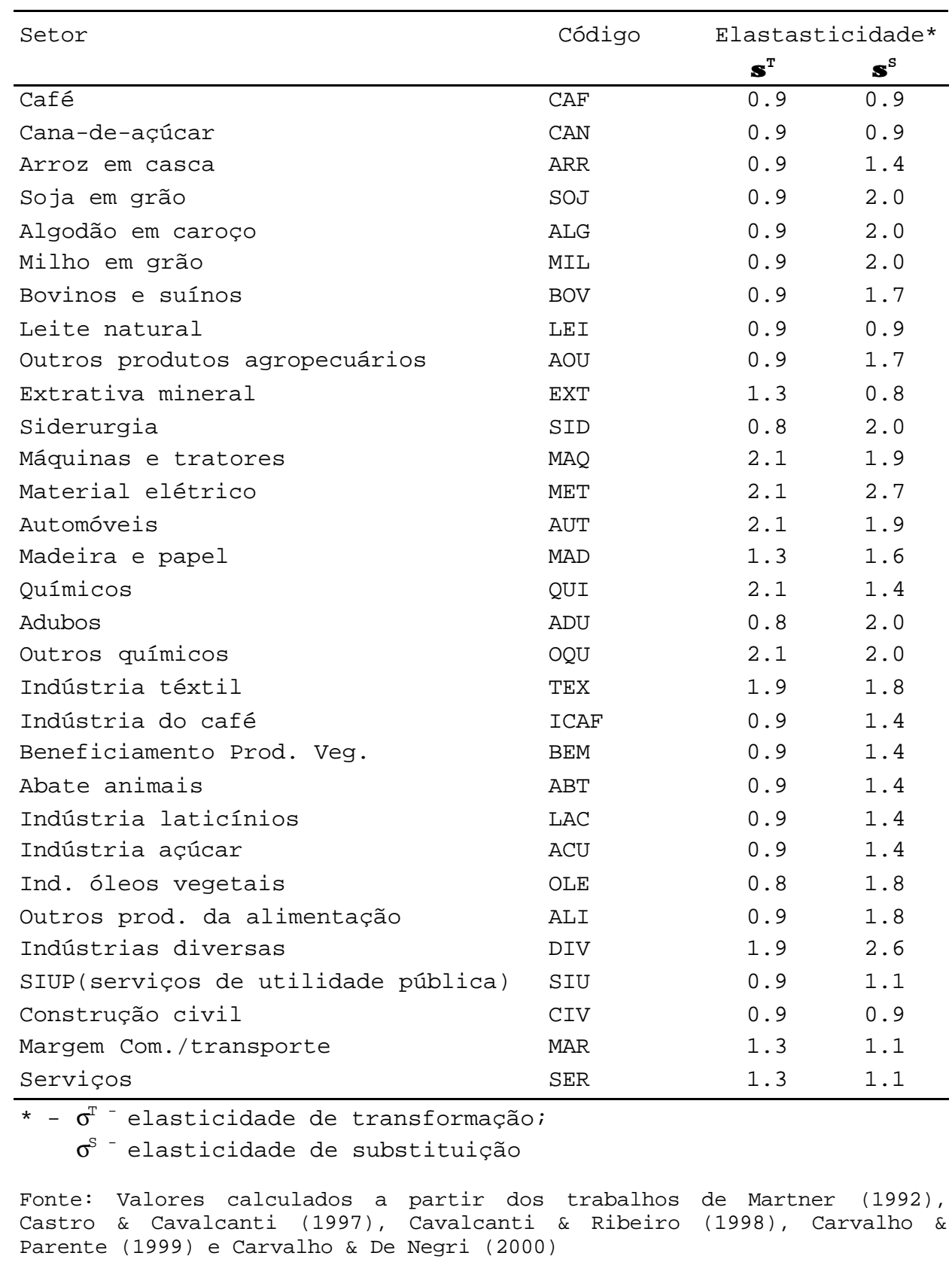




\subsection{Matriz de contabilidade social (SAM)}

De acordo com o que foi apresentado na revisão de literatura, os modelos de equilíbrio geral necessitam de um conjunto de dados base para a chamada calibração, ou seja, o estabelecimento dos parâmetros calculados a partir de um retrato das relações econômicas prevalecentes em um determinado ano base. Para cada estrutura de modelagem, será necessária a elaboração de uma matriz de contabilidade social (SAM) específica, que contemple adequadamente todas as relações e dados exigidos pelo conjunto de equações (ver no Anexo C a estrutura da SAM do modelo). Sendo assim, a implementação de um modelo necessariamente implica na elaboração de uma SAM a partir da base de informações disponíveis em um país. No Brasil o IBGE vem elaborando as Contas Nacionais e as Matrizes Insumo-produto, que constituem a base dos dados originais que serão tratados e adequados ao padrão exigido pelo modelo considerado neste trabalho.

Um aspecto importante é a aderência dos dados ao contexto que se propõe analisar. Como foi discutido, objetiva-se analisar, através do instrumental de equilíbrio geral, o impacto da taxa de câmbio o agronegócio brasileiro, considerando o contexto da sobrevalorização da moeda, ocorrido entre os anos de 1994 e 1999. Evidências da reestruturação do setor produtivo são observadas para o ano 1995, quando, por exemplo, ocorre um aumento de 51,8\% nas importações de bens de capital (Bacen, 1996). Rodrigues \& Guilhoto (1998), analisando os dados da matriz insumo-produto entre 1990 e 1995, concluem que ocorreu elevação da demanda final por bens importados de consumo e de capital. Outra referência do aumento das importações brasileiras referese ao significativo aumento da participação nas importações mundiais, como foi apresentado anteriormente na Figura 16.

A abertura comercial também é evidenciada com base nas tarifas de importação, segundo Oliveira Júnior. (2000) a média entre os anos de 1988 e 1993 era de 25,5\%, o que foi reduzido para 12,3\% a partir de 1994. Na agropecuária, Gasques \& Conceição (2000) salientam a mudança, ocorrida em 1995, no padrão de utilização da mão-de-obra, 
como uma evidência da reestruturação produtiva, baseada na alteração da composição da produção e no uso de insumos.

Observou-se que o ano de 1995 pode ser considerado como sendo parte de um novo contexto de abertura comercial, indicando que a estrutura produtiva já vinha sendo estimulada no sentido da sintonia com uma política mais aberta ao comércio exterior. Assume-se, desta forma, que a matriz de 1995 já tenha incorporado a maior exposição do país ao comércio internacional. Sendo assim, a base para a modelagem foi constituída de um ambiente de produção menos fechado ao comércio internacional, o que aumenta a importância da taxa de câmbio no sentido dos seus efeitos sobre os preços relativos.

Para a elaboração da matriz de contabilidade social (SAM), de acordo com o proposto por Decaluwé et al. (1996), procedeu-se o tratamento das tabelas da matriz Insumo-Produto de 1995 (IBGE, 1995b), conforme especificado no Quadro 1.

\subsubsection{Tratamento da matriz de contabilidade social}

Em função de diferenças existentes entre a metodologia adotada pelo IBGE e o padrão da matriz de contabilidade social (Anexo C), foi necessária a realização de uma série de ajustes. O primeiro ajuste foi a alteração da estrutura original produto $\mathrm{x}$ setor para a estrutura setor $\mathrm{x}$ setor. De acordo com o método proposto por Miller \& Blair (1985), procedeu-se a pré-multiplicação de todas as matrizes insumo-produto originais pela matriz D (matriz de participação de cada setor na produção dos produtos).

Uma vez de posse das matrizes ajustadas para a estrutura setor $\mathrm{x}$ setor, procederam-se às agregações e desagregações, conforme especificado nos ítens seguintes:

1. Sobre os dados de consumo intermediário e demanda final se procedeu à transferência das margens de comércio e transporte para o setor de margens, ou seja, para cada linha se subtrai a margem correspondente e soma-se o valor subtraído à linha de margens. 


\begin{tabular}{|c|c|}
\hline SAM & Tabela origem na matriz Insumo-produto de 1995 \\
\hline $\begin{array}{l}\text { Consumo } \\
\text { intermediário }\end{array}$ & $\begin{array}{l}\text { 2. Tabela de usos de bens e serviços } 1995 \text { - } \\
\text { consumo intermediário das atividades }\end{array}$ \\
\hline \multirow{6}{*}{ Impostos indiretos } & $\begin{array}{c}\text { Tabela } 6 . \text { Tabela de destino do ICMS sobre produtos } \\
\text { nacionais em } 1995\end{array}$ \\
\hline & $\begin{array}{l}\text { 7. Tabela de destino do ICMS sobre produtos } \\
\text { importados em } 1995\end{array}$ \\
\hline & $\begin{array}{l}\text { 8. Tabela de destino do IPI / ISS sobre } \\
\text { produtos nacionais em } 1995\end{array}$ \\
\hline & $\begin{array}{c}\text { Tabela } 9 . \text { Tabela de destino do IPI / ISS sobre } \\
\text { produtos importados em } 1995\end{array}$ \\
\hline & $\begin{array}{c}\text { Tabela 14. Tabela de destino dos outros impostos } \\
\text { sobre produtos nacionais em } 1995\end{array}$ \\
\hline & 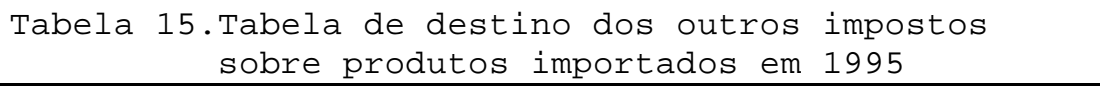 \\
\hline Valor adicion & $\begin{array}{l}\text { 2. Tabela de usos de bens e serviços } 1995 \text { - } \\
\text { componentes do valor adicionado }\end{array}$ \\
\hline Exportações & $\begin{array}{l}\text { 2. Tabela de usos de bens e serviços } 1995 \text { - } \\
\text { demanda final - exportações }\end{array}$ \\
\hline Consumo governo & $\begin{array}{l}\text { 2. Tabela de usos de bens e serviços } 1995 \text { - } \\
\text { demanda final - consumo da administração } \\
\text { pública }\end{array}$ \\
\hline $\begin{array}{l}\text { Consumo das } \\
\text { famílias }\end{array}$ & $\begin{array}{l}\text { 2. Tabela de usos de bens e serviços } 1995 \text { - } \\
\text { demanda final - consumo das famílias }\end{array}$ \\
\hline Investimento & $\begin{array}{l}\text { 2. Tabela de usos de bens e serviços } 1995 \text { - } \\
\text { demanda final - formação bruta de capital } \\
\text { fixo + variação de estoques }\end{array}$ \\
\hline Estoques & $\begin{array}{l}\text { 2. Tabela de usos de bens e serviços } 1995 \text { - } \\
\text { demanda final - variação de estoques }\end{array}$ \\
\hline Importações & $\begin{array}{l}\text { 4. Tabela de oferta e demanda de produtos } \\
\text { importados em } 1995\end{array}$ \\
\hline Taxa de importação & $\begin{array}{l}\text { 5. Tabela de destino do imposto sobre } \\
\text { importação em } 1995\end{array}$ \\
\hline Produção doméstica & $\begin{array}{l}\text { 1. Tabela de recursos de bens e serviços } \\
1995 \text { - oferta de bens e serviços }\end{array}$ \\
\hline Transferências & Contas nacionais de 1995 \\
\hline Imposto de renda & Arrecadação da Receita Federal \\
\hline
\end{tabular}

Quadro 1 - Dados necessários para elaboração da SAM e as respectivas tabelas de origem a partir da Matriz de 1995 e Contas Nacionais de 1995.

Fonte: Elaborado a partir de Decaluwé et al.,1996; IBGE, 1995a; IBGE, 1995b e Receita Federal, 2001. 
2. Para o acerto final da SAM, somou-se o consumo das famílias, o gasto público, a demanda intermediária, o investimento e a variação de estoques, obtendo-se a demanda local por produtos compostos. Desse valor, subtraindo-se as importações, obteve-se a demanda local por produtos domésticos.

3. Somando-se então o valor da demanda doméstica por produtos domésticos com as exportações, obteve-se o valor da produção doméstica total, que deve ser igual à soma do consumo intermediário, impostos indiretos e valor adicionado. A diferença existente foi distribuída proporcionalmente no valor adicionado.

\subsection{Agregações e desagregações}

A escolha dos setores tratados em um modelo constitui um ponto que deve ser muito bem estudado, uma vez que, os inter-relacionamentos existentes entre os setores são uma das vantagens da análise de equilíbrio geral com relação à análise de equilíbrio parcial. Além disso, deve-se também ponderar o tratamento de setores que representem a produção agropecuária e agroindustrial de produtos tradables e non-tradables, ou mais especificamente como apresentado por Melo (1988):

1 - setor non-tradables: são aqueles que apresentam irrisória participação nas exportações e importações;

2 - setores de exportação: são setores que apresentam elevado nível de exportações e baixo nível de importação;

3 - setores tradables de importação: são setores que produzem produtos substitutos ou complementares de importados;

4 - setores dependentes de importados: são setores que produzem produtos nontradables, mas que dependem de insumos importados. 
Sendo assim, para que se pudesse explorar ao máximo as particularidades do agronegócio brasileiro, foi necessária a desagregação da agropecuária, que originalmente é tratada pelo IBGE de forma agregada, a exemplo do observado em Ferreira Filho (1995) e Guilhoto (1995). Ambos os autores utilizaram-se de referências diversas, como dados de consumo de fertilizantes, sementes, participação na produção total, dados do censo agropecuário e outros critérios próprios para a desagregação. No Quadro 2 foi traçado o paralelo entre os setores originalmente tratados pelo IBGE e aqueles que serão considerados no modelo.

\begin{tabular}{|c|c|c|}
\hline Setores originais do IBGE & $\begin{array}{l}\text { Setores tratados no } \\
\text { Modelo }\end{array}$ & $\begin{array}{l}\text { Código no } \\
\text { Modelo }\end{array}$ \\
\hline - Agropecuária & $\begin{array}{l}\text { - Café em coco } \\
\text { - Cana-de-açúcar } \\
\text { - Arroz em casca } \\
\text { - Soja em grão } \\
\text { - Algodão em caroço } \\
\text { - Milho em grão } \\
\text { - Bovinos e suínos } \\
\text { - Leite natural } \\
\text { - Outros produtos } \\
\text { agropecuários }\end{array}$ & $\begin{array}{l}\text { CAF } \\
\text { CAN } \\
\text { ARR } \\
\text { SOJ } \\
\text { ALG } \\
\text { MIL } \\
\text { BOV } \\
\text { LEI } \\
\text { AOU }\end{array}$ \\
\hline $\begin{array}{l}\text { - Extrativa Mineral } \\
\text { - Extração de Petróleo e gás }\end{array}$ & - Extrativa mineral & $\mathrm{EXT}$ \\
\hline $\begin{array}{l}\text { - Siderurgia } \\
\text { - Metalúrgia não-ferrosos } \\
\text { - Outros metalúrgicos }\end{array}$ & - Siderurgia & SID \\
\hline - Máquinas e tratores & - Máquinas e tratores & MAQ \\
\hline $\begin{array}{l}\text { - Material elétrico } \\
\text { - Equipamentos eletrônicos }\end{array}$ & - Material elétrico & $\mathrm{MET}$ \\
\hline $\begin{array}{l}\text { - Automóveis, caminhões e ônibus } \\
\text { - Outros veículos e peças }\end{array}$ & - Automóveis & AUT \\
\hline $\begin{array}{l}\text { - Madeira e mobiliário } \\
\text { - Papel e gráfica }\end{array}$ & - Madeira e papel & MAD \\
\hline $\begin{array}{l}\text { - Elementos químicos } \\
\text { - Refino do petróleo } \\
\text { - Químicos diversos/tintas } \\
\text { - Farmacêutica e perfumaria } \\
\text { - Artigos de plástico } \\
\text { - Químicos diversos (resíduo) }\end{array}$ & - Químicos & QUI \\
\hline
\end{tabular}

Quadro 2 - Paralelo entre a estrutura original de setores do IBGE em relação ao modelo. 


\begin{tabular}{|c|c|c|}
\hline Setores originais do IBGE & $\begin{array}{l}\text { Setores tratados no } \\
\text { Modelo }\end{array}$ & $\begin{array}{l}\text { Código no } \\
\text { Modelo }\end{array}$ \\
\hline - Químicos Diversos & 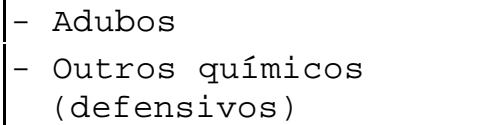 & $\begin{array}{l}\text { ADU } \\
\text { OQU }\end{array}$ \\
\hline $\begin{array}{l}\text { - Indústria têxtil } \\
\text { - Artigos do vestuário } \\
\text { - Fabricação de calçados }\end{array}$ & - Indústria têxtil & TEX \\
\hline - Indústria do café & - Indústria do café & ICAF \\
\hline - Beneficiamento prod. Vegetal & $\begin{array}{l}\text { - Beneficiamento prod. } \\
\text { Veg. }\end{array}$ & $B E N$ \\
\hline - Abate de animais & - Abate animais & $\mathrm{ABT}$ \\
\hline - Indústria de laticínios & - Indústria laticínios & LAC \\
\hline - Indústria do açúcar & - Indústria açúcar & $\mathrm{ACU}$ \\
\hline - Fabricação de óleos vegetais & - Ind. óleos vegetais & OLE \\
\hline - Outros Produtos alimentares & $\begin{array}{l}\text { - Outros produtos } \\
\text { alimentares }\end{array}$ & $\mathrm{ALI}$ \\
\hline $\begin{array}{l}\text { - Indústrias Diversas } \\
\text { - Indústria da borracha } \\
\text { - Minerais não-metálicos }\end{array}$ & - Indústrias diversas & DIV \\
\hline $\begin{array}{l}\text { - Serv. Indust. Utilidade } \\
\text { pública } \\
\text { - Comunicações } \\
\text { - Instituições financeiras }\end{array}$ & - S.I.U.P & SIU \\
\hline - Construção civil & - Construção civil & $\mathrm{CIV}$ \\
\hline $\begin{array}{l}\text { - Margem comércio } \\
\text { - Margem transporte }\end{array}$ & $\begin{array}{l}\text { - Margem comércio e } \\
\text { transporte }\end{array}$ & MAR \\
\hline $\begin{array}{l}\text { - Serv. Prestados às famílias } \\
\text { - Serv. Prest. Às empresas } \\
\text { - Aluguel de imóveis } \\
\text { - Serviços privados não } \\
\text { mercantis } \\
\text { - Dummy financeira }\end{array}$ & - Serviços & SER \\
\hline - Administração pública & - Administração pública & SAD \\
\hline
\end{tabular}

Quadro 2 - Paralelo entre a estrutura original de setores do IBGE em relação ao modelo.

Apresentou-se também no Quadro 2 o código de cada setor, que será utilizado nos gráficos e tabelas do capítulo Resultados. Como pode ser observado, foi necessária a realização de algumas agregações e desagregações, resultando em um total de 32 setores. Destes, nove são diretamente relacionados com a produção agropecuária, quais 
sejam os seus códigos CAF, CAN, ARR, SOJ, ALG, MIL, BOV, LEI e AOU; 9 são relacionados com a produção agroindustrial, quais sejam MAD, TEX, ICAF, BEN, $\mathrm{ABT}, \mathrm{LAC}, \mathrm{ACU}, \mathrm{OLE}$ e ALI; e 14 são relacionados como não participantes do agronegócio (indústria e serviços).

A agregação de setores segue o procedimento tradicional de somatório de colunas e linhas dos setores e produtos que estão sendo agregados. Por outro lado, o processo de desagregação, realizado para o setor agropecuário e para o setor químicos diversos, exigiu algum tratamento adicional e a utilização de informações de outras fontes. A seguir, serão descritos os critérios utilizados para a desagregação do setor agropecuário.

\subsubsection{Desagregação do setor agropecuário}

A escolha dos setores a serem desagregados tem uma relação direta com as informações disponíveis nas matrizes insumo-produto. Nas referidas matrizes, o IBGE trata separadamente os produtos café em coco, cana-de-açúcar, arroz em casca, trigo em grão, soja em grão, algodão em caroço, milho em grão, bovinos/suínos, leite natural, aves vivas e outros produtos agropecuários. Sendo assim, os setores que podem ser mais facilmente desagregados do setor agropecuário, são aqueles associados aos produtos tratados separadamente pelo IBGE, como procederam Ferreira Filho (1995) e Guilhoto (1995). A desagregação de qualquer outro setor não associado aos produtos citados exigiria um estudo completo de relações intersetorias, o que extrapolaria os objetivos do presente trabalho.

Uma vez conhecidos os setores possíveis de serem desagregados do setor agropecuário, procedeu-se à distribuição dos valores com base em informações do Censo Agropecuário de 1995/1996 (IBGE, 1997). No Quadro 3 descreve-se, para cada produto relacionado com o setor agropecuário, qual foi o critério de distribuição do valor original entre os novos setores desagregados.

Com os critérios de desagregação definidos, procedeu-se a modificação de todas as matrizes que compõem a SAM, apresentadas anteriormente no Quadro 1. 


\begin{tabular}{|c|c|}
\hline $\begin{array}{l}\text { Produtos consumidos pelo setor } \\
\text { Agropecuário }\end{array}$ & $\begin{array}{c}\text { Critério para distribuição entre os } \\
\text { setores desagregados }\end{array}$ \\
\hline Café em coco & $100 \%$ no setor Café ${ }^{1}$ \\
\hline Cana-de-açúcar & $100 \%$ no setor Cana $^{1}$ \\
\hline Arroz em casca & $100 \%$ no setor Arroz ${ }^{1}$ \\
\hline Trigo em grão & $100 \%$ no setor Outros da agropecuária ${ }^{1}$ \\
\hline Soja em grão & $100 \%$ no setor Soja ${ }^{1}$ \\
\hline Algodão em caroço & $100 \%$ no setor algodão ${ }^{1}$ \\
\hline Milho em grão & \begin{tabular}{|l} 
1,2\% no setor Milho, \\
$33,0 \%$ no setor Bovinos/suínos, \\
1,6\% no setor Leite e \\
$64,0 \%$ no setor Outros da agropecuária ${ }^{1}$
\end{tabular} \\
\hline Bovinos e suínos & $100 \%$ no setor Bovinos/Suínos ${ }^{1}$ \\
\hline Leite natural & $100 \%$ no setor Leite ${ }^{1}$ \\
\hline Aves vivas & $100 \%$ no setor Outros da agropecuária ${ }^{1}$ \\
\hline Outros produtos agropecuários & $100 \%$ no setor Outros da Agropecuária ${ }^{1}$ \\
\hline Outros minerais & Despesas totais ${ }^{2}$ \\
\hline Produtos minerais não metálicos & Despesas totais ${ }^{2}$ \\
\hline Outros produtos metalúrgicos & Total de tratores ${ }^{2}$ \\
\hline $\begin{array}{l}\text { Fabricação e manutenção de } \\
\text { máquinas e equipamentos }\end{array}$ & Total de tratores ${ }^{2}$ \\
\hline Material elétrico & Despesas com energia elétrica ${ }^{2}$ \\
\hline Outros veículos e peças & Total de tratores ${ }^{2}$ \\
\hline Madeira e mobiliário & Total estabelecimentos ${ }^{2}$ \\
\hline $\begin{array}{l}\text { Papel, celulose, papelão e } \\
\text { artefatos }\end{array}$ & Despesas com sacarias outras embalagens \\
\hline óleos combustíveis & Despesas com combustíveis e lubrificantes \\
\hline Outros produtos do refino & Despesas com combustíveis e lubrificantes $^{2}$ \\
\hline Produtos petroquímicos básicos & Despesas com combustíveis e lubrificantes ${ }^{2}$ \\
\hline Resinas & Despesas com combustíveis e lubrificantes ${ }^{2}$ \\
\hline Gasoalcool & Despesas com combustíveis e lubrificantes $^{2}$ \\
\hline Adubos & Despesas com adubos e corretivos ${ }^{2}$ \\
\hline Defensivos & $\begin{array}{l}\text { Despesas com agrotóxicos e Medicamentos p/ } \\
\text { animais } 2\end{array}$ \\
\hline $\begin{array}{l}\text { Produtos farmacêuticos e } \\
\text { perfumaria }\end{array}$ & Despesas com Medicamentos $\mathrm{p} /$ animais $^{2}$ \\
\hline Artigos de plásticos & Despesas com sacarias outras embalagens ${ }^{2}$ \\
\hline Fios texteis naturais & Despesas com sacarias outras embalagens ${ }^{2}$ \\
\hline Outros prod. têxteis & Despesas com sacarias outras embalagens ${ }^{2}$ \\
\hline Produtos de couro e calçados & Pessoal ocupado ${ }^{2}$ \\
\hline Açúcar & Pessoal ocupado ${ }^{2}$ \\
\hline óleos vegetais em bruto & Despesa com outros alimentos ${ }^{2}$ \\
\hline $\begin{array}{l}\text { Outros produtos alimentares } \\
\text { inclusive rações }\end{array}$ & Despesas com rações industriais ${ }^{2}$ \\
\hline Produtos diversos & Despesas totais ${ }^{2}$ \\
\hline $\begin{array}{l}\text { Serviços industriais de utilidade } \\
\text { pública }\end{array}$ & Despesas com energia elétrica \\
\hline
\end{tabular}

\section{Quadro 3 - Detalhamento dos critérios utilizados na desagregação do setor agropecuário.}




\begin{tabular}{|c|c|}
\hline $\begin{array}{l}\text { Produtos consumidos pelo setor } \\
\text { Agropecuário }\end{array}$ & $\begin{array}{c}\text { Critério para distribuição entre os } \\
\text { setores desagregados }\end{array}$ \\
\hline Produtos da construção civil & Número de estabelecimentos ${ }^{2}$ \\
\hline Margem de comércio & Valor da produção - Matriz Insumo Produto \\
\hline Margem de transporte & Despesas com transporte da produção ${ }^{2}$ \\
\hline Comunicações & Pessoal ocupado ${ }^{2}$ \\
\hline Seguros & Despesas com juros e despesas bancárias ${ }^{2}$ \\
\hline Serviços financeiros & Despesas com juros e despesas bancárias ${ }^{2}$ \\
\hline Alojamento e alimentação & Pessoal ocupado ${ }^{2}$ \\
\hline Outros serviços & Pessoal ocupado ${ }^{2}$ \\
\hline Serviços prestados às empresas & Despesas com serviços de empreitada ${ }^{2}$ \\
\hline Aluguel de imóveis & $\begin{array}{l}\text { Despesas com Aluguel de máquinas e } \\
\text { equipamento } 2\end{array}$ \\
\hline
\end{tabular}

Quadro 3 - Detalhamento dos critérios utilizados na desagregação do setor agropecuário.

Fonte das variáveis utilizadas nos critérios de desagregação:

1- critério do autor com base em outros trabalhos

2- Censo Agropecuário 95/96 (IBGE, 1997)

3- Matriz Insumo produto (IBGE, 1995)

\subsubsection{Desagregação do setor Químicos Diversos}

De acordo com a proposta do presente trabalho, considerou-se de suma importância que os principais fornecedores de insumos de produção (máquinas, adubos e defensivos) para a agropecuária, fossem tratados da forma mais específica possível. $\mathrm{Na}$ estrutura de produtos discriminada pelo IBGE em sua matriz insumo-produto de 1995, aparecem individualizados os produtos Máquinas/tratores e Adubos, mas não aparece o produto Defensivos e Medicamentos de uso agropecuário. De acordo com a Classificação Nacional de Atividades Econômicas (IBGE, 2000), a denominação "Outros Produtos Químicos" inclui defensivos agrícolas e medicamentos de uso agropecuário, entre outros elementos utilizados por diferentes setores. Sendo assim, considerou-se que o consumo de "Outros produtos químicos" pelo setor da agropecuária corresponde ao consumo de Defensivos e Medicamentos Veterinários. 
Os dois produtos "Adubos" e "Outros Produtos Químicos" estão atrelados a um único setor denominado "Químicos Diversos" na matriz do IBGE. Desta forma, para que fosse possível captar as inter-relações com os setores da agropecuária, foi necessário desagregar do setor "Químicos Diversos" nos novos setores "Adubos" e "Outros químicos". A criação dos novos setores implicou na adoção de um critério de alocação do consumo intermediário de produtos como se especifica a seguir:

1) $100 \%$ do consumo intermediário do produto "Adubos", realizado pelo setor "Químicos diversos", passou para o novo setor "Adubos";

2) $100 \%$ do consumo intermediário de "Outros produtos químicos" realizado pelo setor "Químicos diversos", passou para o novo setor "Outros químicos";

3) $100 \%$ do consumo intermediário de tintas, o terceiro produto associado ao setor "Químicos Diversos", que não é do interesse específico da agropecuária, permaneceu no setor "Químicos diversos".

Os demais produtos de consumo intermediário do setor original "Químicos diversos" foram distribuídos entre os novos setores, Adubos e Outros químicos, com base na participação relativa na produção dos produtos, $31 \%$ adubos e $42 \%$ outros químicos.

Desta forma, foi possível tratar de forma mais específica, dois setores de grande importância para a agropecuária. Cabe ainda esclarecer que a distribuição do consumo intermediário de Adubos e Outros químicos, entre os novos setores agropecuários, seguiu o procedimento já descrito no item 3.3.1.

\subsubsection{Demais critérios adotados nas desagregações}

A desagregação da Matriz D (Matriz de participação setorial na produção dos produtos nacionais - Market Share), utilizada na conversão da estrutura produto x setor para a setor $\mathrm{x}$ setor, foi realizada conforme a afinidade do produto ao setor desagregado. 
Com relação à desagregação do valor adicionado, adotaram-se referências as mais próximas possíveis como especificado no Quadro 4.

\begin{tabular}{|l|l|}
\hline Item do Valor Adicionado & $\begin{array}{l}\text { Critério para distribuição entre os } \\
\text { setores desagregados }\end{array}$ \\
\hline Remunerações & $\begin{array}{l}\text { Participação nos salários pagos em } \\
\text { dinheiro e produto }{ }^{-}\end{array}$ \\
\hline Excedente operacional bruto & $\begin{array}{l}\text { Participação no Consumo } \\
\text { Intermediário da agropecuária }{ }^{2}\end{array}$ \\
\hline $\begin{array}{l}\text { Outros impostos sobre a } \\
\text { produção }\end{array}$ & Participaço nos Impostos totais ${ }^{3}$ \\
\hline Outros subsídios à produção & Participação nos Impostos totais ${ }^{3}$ \\
\hline
\end{tabular}

Quadro 4 - Critérios adotados na desagregação dos ítens do valor adicionado.

Fonte das variáveis utilizadas nos critérios de desagregação:

1 - Censo Agropecuário 95/96 (IBGE, 1997)

2 - Matriz Insumo produto (IBGE, 1995b)

3 - Calculado pelo autor após a desagregação das matrizes de imposto

Para o caso do valor adicionado pelo setor "Químicos diversos", o uso dos dados da Pesquisa Industrial Anual - PIA - 1995 (IBGE, 1995c) não foi possível, dada a ausência do produto TINTAS. Adotou-se, então, o referencial de participação relativa dos três produtos (Adubos, Tintas e Outros químicos) no Consumo intermediário do setor "Químicos Diversos".

\subsection{Geração e avaliação de impacto sobre o modelo}

A análise de equilíbrio geral, como foi discutido na revisão de literatura, apresenta uma série de vantagens em relação à análise de equilíbrio parcial. O principal aspecto a ser explorado é a verificação da reação da estrutura produtiva de 1995, face à alteração da taxa de câmbio, variável macroeconômica de grande influência sobre os preços relativos da economia. O sentido da alteração da taxa de câmbio está associado à análise contra factual do observado na economia durante o ano de 1995, quando a taxa de câmbio se encontrava sobrevalorizada. Sendo assim, para se verificar a hipótese de 
que a sobrevalorização não estaria associada a um sistemático efeito negativo sobre o agronegócio, procedeu-se à desvalorização da taxa de câmbio, de forma a se identificar qual seria a reação.

De acordo com procedimento adotado por Najberg et al. (1995) e Bautista et al. (1998), procedeu-se à modificação do Balanço de transações correntes em valor igual a US\$ 5 bilhões de dólares, em etapas sucessivas, até tornar esta variável igual a zero. Em resposta a essa modificação observou-se o ajustamento endógeno da taxa de câmbio nominal e os seus conseqüentes impactos sobre os preços relativos e as demais variáveis da economia.

Para a constatação dos impactos sobre preços relativos, foram ainda definidos alguns índices, conforme detalhado a seguir:

1. Índice de preços pagos ou custo setorial (IPP): o índice de preços pagos foi calculado considerando-se os preços pagos pelo setor em seu consumo intermediário. Com o preço composto (definido na equação 36) e a participação de cada setor no consumo intermediário do setor tratado, calculou-se a média ponderada. Desta forma, o índice de custo setorial reflete o impacto da alteração da taxa de câmbio sobre o preço composto pago pelos setores em seu consumo intermediário. No sentido de precisar ainda mais o impacto sobre a relação com os demais setores, calculou-se, também, o índice de custo setorial geral e o extra-setor, sendo o segundo correspondente ao preço composto pago pelo setor aos outros setores que não ele mesmo.

2. Índice preços recebidos/preços pagos (IPR/IPP): através deste índice verificou-se como cada setor foi afetado, no sentido dos seus termos de troca com os outros setores. O índice IPR/IPP tomou por base o preço para a produção (definido na equação 32) em relação ao índice de preços pagos (IPP). Os setores que apresentaram redução do IPR/IPP tiveram uma perda em favor daqueles que são seus fornecedores. Por outro lado, aqueles que apresentaram aumento do IPR/IPP são os beneficiados com a desvalorização da taxa de câmbio, ou seja, ganharam em detrimento dos seus fornecedores. 
Em função do número total de setores tratados no modelo, em vários momentos foi utilizada a média por grupo de setores de forma a se possibilitar a realização de comparações mais gerais. Para tal, apresenta-se no Quadro 5 os grupos e os setores que dele fazem parte.

\begin{tabular}{|l|c|}
\hline Grupo & Código do Setor constituinte \\
\hline Agropecuário & CAF, CAN, ARR, SOJ, ALG, MIL, BOV, LEI e AOU \\
\hline Agroindustrial & MAD, TEX, ICAF, BEN, ABT, LAC, ACU, OLE e ALI \\
\hline Industrial & EXT, SID, MAQ, MET, AUT, QUI, ADU, OQU, e DIV \\
\hline Serviços & SIU, CIV, MAR, SER e SAD \\
\hline
\end{tabular}

Quadro 5 - Grupos de setores tratados no modelo.

Operacionalmente, o modelo foi implementado com base na linguagem de programação matemática do sistema GAMS (The General Algebraic Modeling System), a partir da programação original desenvolvida por Decaluwé et al. (1996), apresentada no Anexo E já com as devidas adaptações e a inclusão dos dados da SAM. A solução do sistema passou por duas fases: a primeira para a obtenção dos valores dos parâmetros a partir da SAM (calibração); e a segunda para a obtenção da solução base a partir da utilização do solver para sistemas de equações não-lineares denominado GAMS/MINOS. Tendo em mãos a solução base, realizou-se o choque no balanço de transações correntes (variável exógena) e a obtenção de uma nova solução com o ajustamento da taxa de câmbio e das demais variáveis endógenas. Maiores detalhes sobre a funcionalidade e aplicabilidade do GAMS em modelos de equilíbrio geral podem ser obtidos em Brooke et al. (1996) e Löfgren et al. (2001).

No capítulo seguinte, serão apresentados os resultados obtidos e a discussão sobre como os setores agropecuários e os setores agroindustriais foram afetados pela desvalorização da taxa de câmbio. 


\section{RESULTADOS E DISCUSSÃO}

Uma vez calibrado o modelo, conforme a base de dados organizada na matriz de contabilidade social (Anexo C), procedeu-se a modificação do balanço de transações correntes em passos de US\$ 5 bilhões até tornar o seu valor igual a zero. Para cada modificação o modelo gerou um equilíbrio a partir do ajuste endógeno da taxa de câmbio nominal, sendo os valores obtidos apresentados na Figura 19.

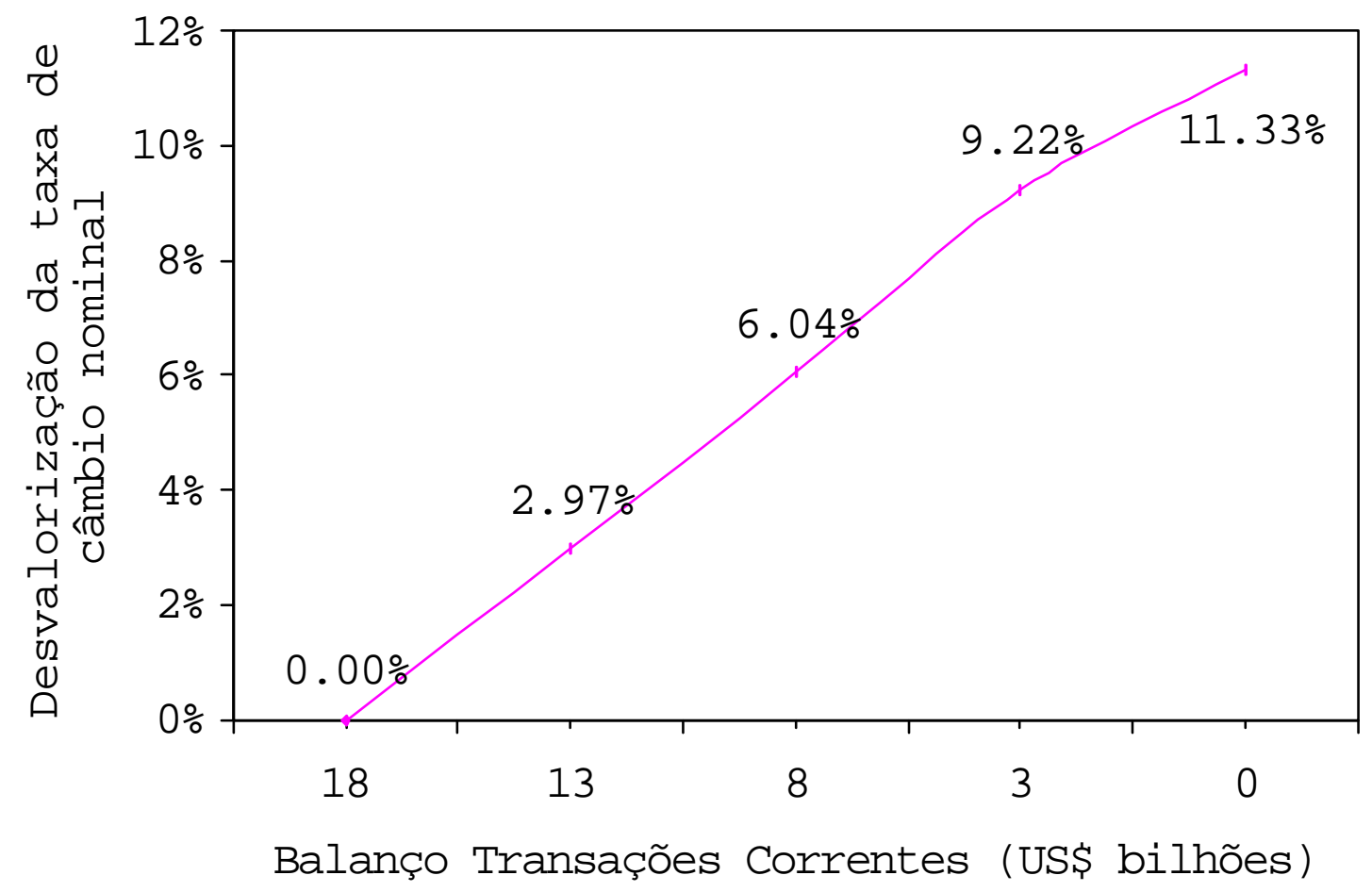

Figura 19 - Desvalorização da taxa de câmbio nominal referente à reduções marginais do Balanço de transações correntes em US\$ 5 bilhões. 
Como pode ser observado na Figura 19, ao zerar o Balanço de transações correntes, induziu-se uma desvalorização de $11,33 \%$ na taxa de câmbio nominal, sendo a resposta dos agregados da economia brasileira, a esse valor, analisados a seguir:

\subsection{Impacto da desvalorização do câmbio sobre as relações externas}

A desvalorização cambial afetou, como era esperado as exportações e importações de forma inversa, tendo a primeira apresentado elevação do volume negociado com o resto do mundo e a segunda redução do volume negociado (Figura 20).

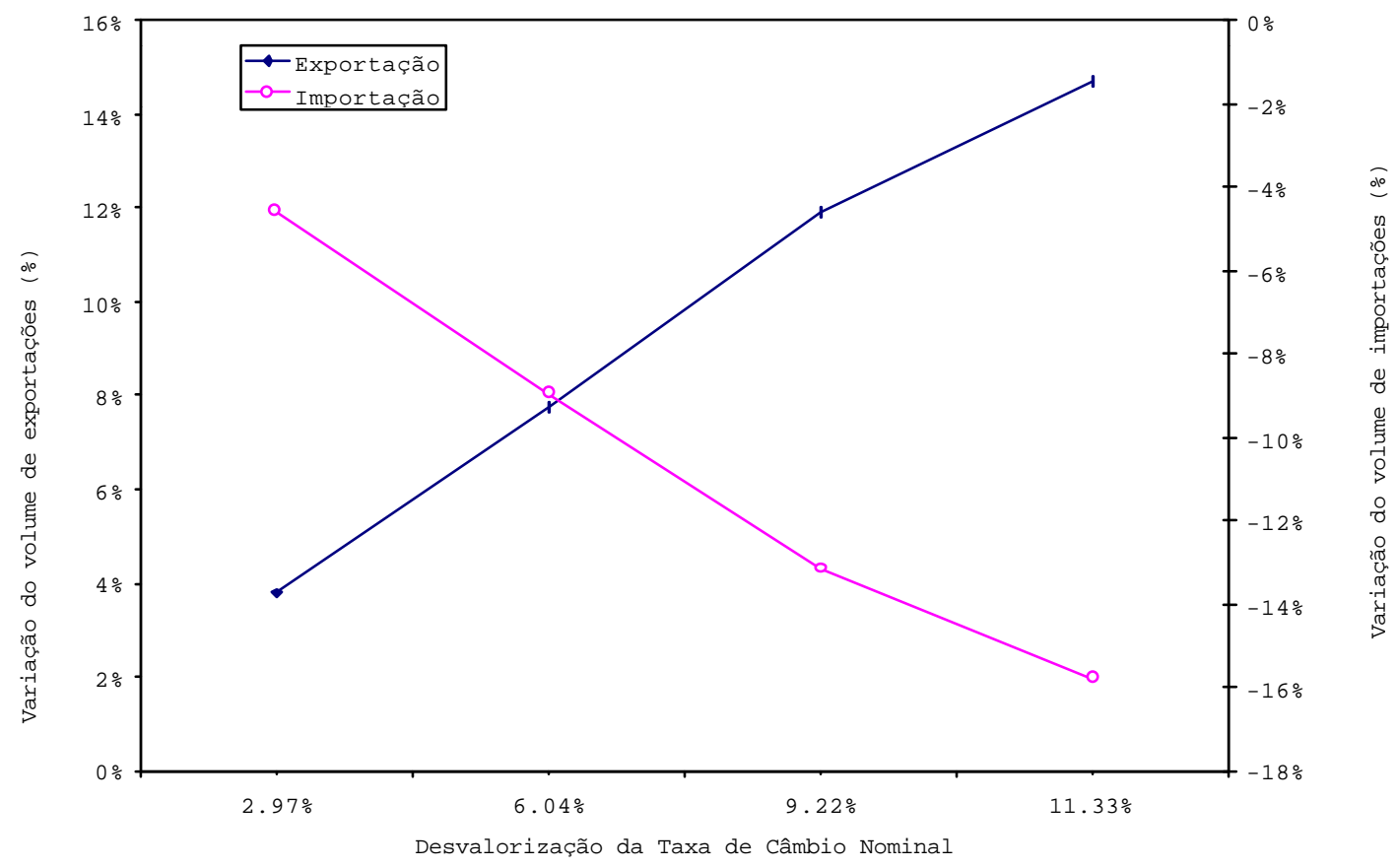

Figura 20 - Impacto da desvalorização da taxa de câmbio nominal sobre as exportações e importações.

Comparativamente o volume exportado reagiru em intensidade menor que o volume importado, efeitos estes que serão discutidos em detalhes a seguir. 


\subsubsection{Exportações}

A variação da participação das exportações na produção total é uma forma de se avaliar como a desvalorização gerou modificação no destino da produção, mercado doméstico vis-à-vis o mercado externo. Primeiramente, tomando-se como referência a informação apresentada na Figura 21, os setores que destinam a maior parcela da produção para o mercado externo são a Indústria do Café (33\%), Indústria do Açúcar (33\%), Indústria de Óleos Vegetais $(26,8 \%)$ e a Extrativa Mineral (23\%). A mesma informação tratada por grupo de setores, grupos estes constituídos conforme foi especificado no Quadro 5, retrata que a agropecuária no todo destina apenas 1,9\% de sua produção para o mercado externo, assim como o grupo serviços com $1,4 \%$, indicando o comportamento não-comercializável (non-tradable) desses grupos. Por outro lado, a Indústria e a Agroindústria apresentam valores 9\% e 12\% da produção respectivamente, indicando um relativo maior destino para o mercado externo.

Em linhas gerais, a economia brasileira, de acordo com a base de dados de 1995, ainda é uma economia pouco voltada para o setor externo, em especial a agropecuária quando tratada na média dos setores que a constituem. Ocorre que alguns setores possuem um maior grau da produção voltada ao exterior, ratificando a posição de país exportador de commodities: açúcar, café, óleo vegetal e ferro. Espera-se que esses setores sejam mais afetados por estímulos oriundos da variação da taxa de câmbio, afetando indiretamente os setores agropecuários fornecedores de insumos.

Avaliando-se o impacto da desvalorização da taxa de câmbio sobre a parcela da produção destinada para a exportação, a partir da Figura 21, observou-se que o setor que reagiu modificando com maior intensidade o destino da produção para exportação, foi o de Máquinas/Tratores, que passou de $9,5 \%$ para $12 \%$ da produção destinada ao mercado externo, correspondendo à $27 \%$ de alteração. Em seguida aparece o setor Automóveis que apresentou modificação de $12,1 \%$ para $14,7 \%$ ( $21 \%$ de alteração). O setor de Material elétrico também apresentou significativa modificação (20\%) da parcela destinada para exportação. Por outro lado, os setores Indústria do Café, Indústria do 
Açúcar, Indústria de Óleos Vegetais e a Extrativa Mineral, apresentaram alteração da participação das exportações em 5,7\%,8,1\%,4,7\% e 6,6\% respectivamente.

Calculando-se a média de alteração por grupos de setores, constatou-se que o grupo Industrial apresentou $15,4 \%$ de alteração média, seguido pelos grupos Agroindustrial com 9,8\% e pelo Agropecuário com 5,8\%.

Naturalmente, a resposta observada foi influenciada pelas elasticidades de transformação adotadas no modelo, conforme foi especificado na Metodologia. O grupo Industrial, ao apresentar elasticidade de transformação superior aos demais grupos (em média igual a 1,7), respondeu mais intensamente à desvalorização, ou seja, o volume por ele exportado foi mais sensível aos preços relativos (preço exportação/preço doméstico). Por outro lado, o grupo agropecuário, ao presentar elasticidade média de transformação igual a 0,9 , respondeu com intensidade menor.

No que tange à verificação do impacto da desvalorização cambial sobre o volume de exportações dos setores tratados no modelo, tem-se a informação sobre a variação percentual em relação à base inicial do volume exportado, apresentada na Figura 22. Apresenta-se também na Figura 22 o volume exportado correspondente à base inicial do modelo, para que se possa verificar sobre que patamar a variação percentual ocorreu. A variação da exportação do grupo agroindustrial, além de ter sido superior ao grupo agropecuário, ocorreu sobre uma base comparativamente maior de exportação e foi em média igual a 13\%. O grupo de setores industriais, em contrapartida, apresentou aumento relativamente maior em resposta à desvalorização da taxa de câmbio, além de ocorrer sobre uma base inicial ainda maior, sendo o valor médio igual a 16,7\%. 


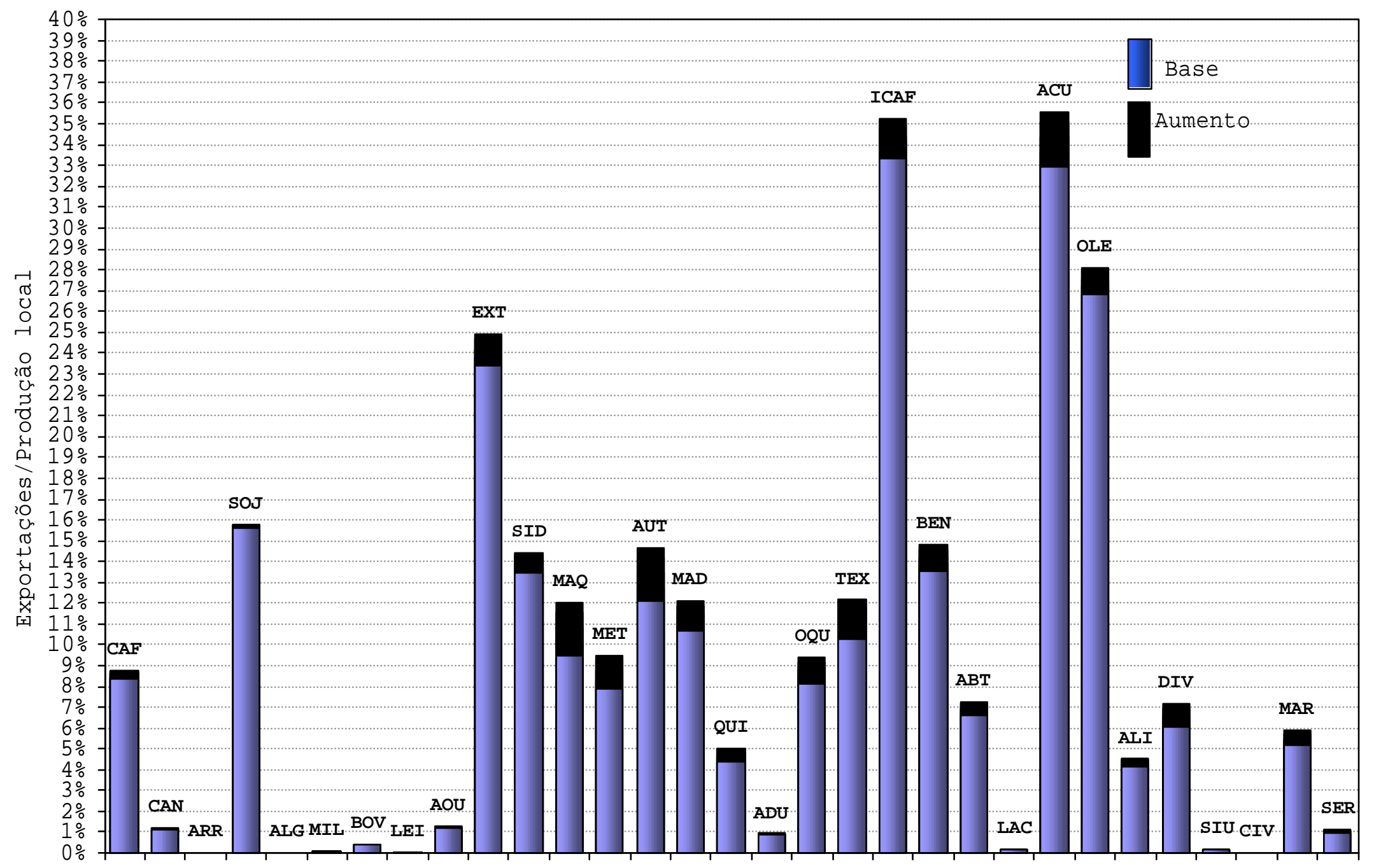

Figura 21 - Participação das exportações com relação à produção doméstica e o impacto da desvalorização da taxa de câmbio. 


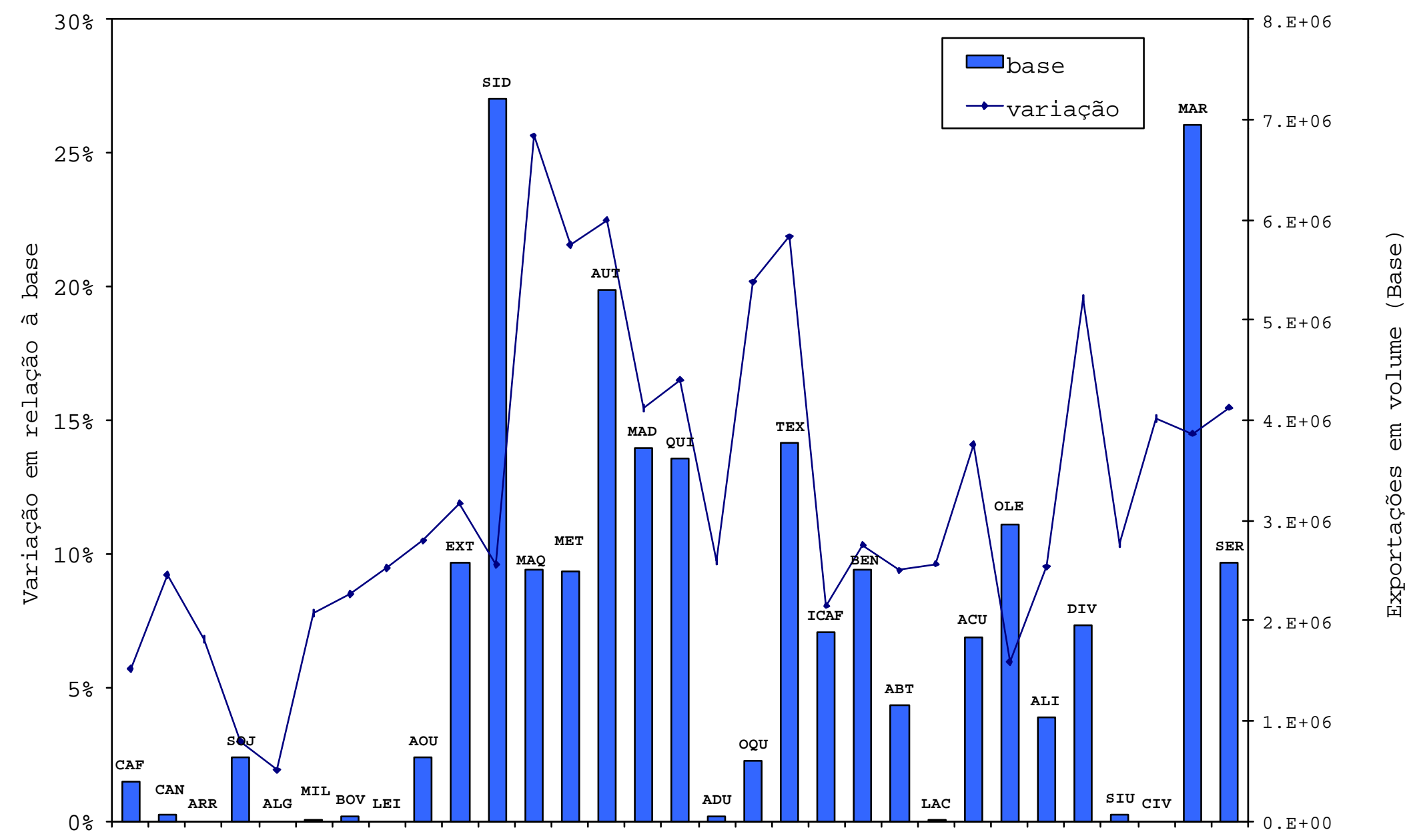

Figura 22 - Efeito da desvalorização sobre as exportações por setor. 
O comportamento retratado no modelo está de acordo com as dificuldades que as exportações brasileiras de produtos básicos (primários) e semimanufaturados enfrentam para se expandirem, dado o perfil da demanda externa, mais inelástica à variação de preços. As exportações agroindustriais são voltadas para o atendimento da demanda de insumos de produção animal ou da indústria alimentícia externa, que atuam em mercados estabilizados com pouca expansão. Desta forma, a arquitetura "Armington", adotada no modelo para o setor externo, possibilitou a incorporação de um comportamento mais real, mesmo assumindo-se concomitantemente a hipótese do país pequeno, que não impõe limites ao volume exportado.

Com base no exposto, percebe-se que o grupo agropecuário foi diretamente menos estimulado pela desvalorização, comparativamente aos grupos agroindustrial e industrial. Há, por outro lado, o efeito indireto da demanda agroindustrial sobre a agropecuária, mais acentuado para os setores agropecuários que se relacionam com os setores da Indústria do Açúcar, do Café e do Óleo vegetal, com maior participação da exportação na produção, e para a Indústria Têxtil, com maior elasticidade de transformação.

\subsubsection{Importações}

Analisando-se inicialmente a participação das importações na oferta composta total, observou-se que os setores Industriais possuem em média um maior grau de participação das importações, 13,4\% em média, considerando-se a base inicial de dados adotada. Os setores da agropecuária seguem com 2,8\% em média, os da agroindústria com 4,3\% e os setores de serviços com 1,5\%. A Figura 23 apresenta o valor de participação das importações setoriais para cada um dos setores tratados. Chama-se a atenção sobre o setor de Extração Mineral, que também apresentou valor destacado para a participação das exportações na produção total (Figura 21). Esse comportamento advém dos produtos agregados nesse setor, minério de ferro associado com exportação e petróleo/gás associado com importação. 
Para os demais setores, percebeu-se um padrão diferente do observado para as exportações, sendo os mais destacados em participação das importações na oferta total os setores Material Elétrico, Máquinas e tratores, Adubos e Automóveis.

Um importante aspecto relacionado com o foco deste trabalho foi a participação das importações na oferta total dos setores fornecedores de insumos para a agropecuária, Químicos (11\%), Adubos (16\%) e Outros químicos (8,9\%). Estes valores mostram, que o efeito do choque promovido na economia, advindo da desvalorização da taxa de câmbio, deve ter um importante elemento de destaque para os custos agropecuários. Uma desvalorização eleva os preços dos produtos importados, afetando os setores e os seus preços compostos na proporção da participação das importações na oferta composta total.

Analisando a modificação ocorrida na participação das importações na oferta total, face à desvalorização do câmbio, percebeu-se que ocorreu redução da participação de importados para todos os setores (Figura 23). Os principais setores fornecedores de insumos para os setores da agropecuária (químicos, adubos e outros químicos), apresentaram redução da participação das importações correspondentes à $8 \%, 11 \%$ e 13\% respectivamente. Redução mais acentuada ocorreu para as Indústrias Diversas, Material Elétrico, Siderurgia e Máquinas/tratores, de 20\%, $18 \%, 17 \%$ e $17 \%$ respectivamente.

O comportamento observado, assim como no caso das exportações, foi influenciado pela elasticidade de substituição atribuída para cada setor. Conforme foi discutido na Metodologia, os trabalhos aplicados que estimaram equações de importação para o Brasil, apresentam elasticidades de substituição superiores a 1 para bens de capital, bens intermediários, produtos não duráveis e duráveis, sendo apenas para combustíveis inferior a 1. Esse tratamento, de certa forma, flexibiliza o impacto em custos do setor agropecuário, ao permitir que os setores fornecedores de insumos substituam parte da parcela importada pela produção doméstica. 


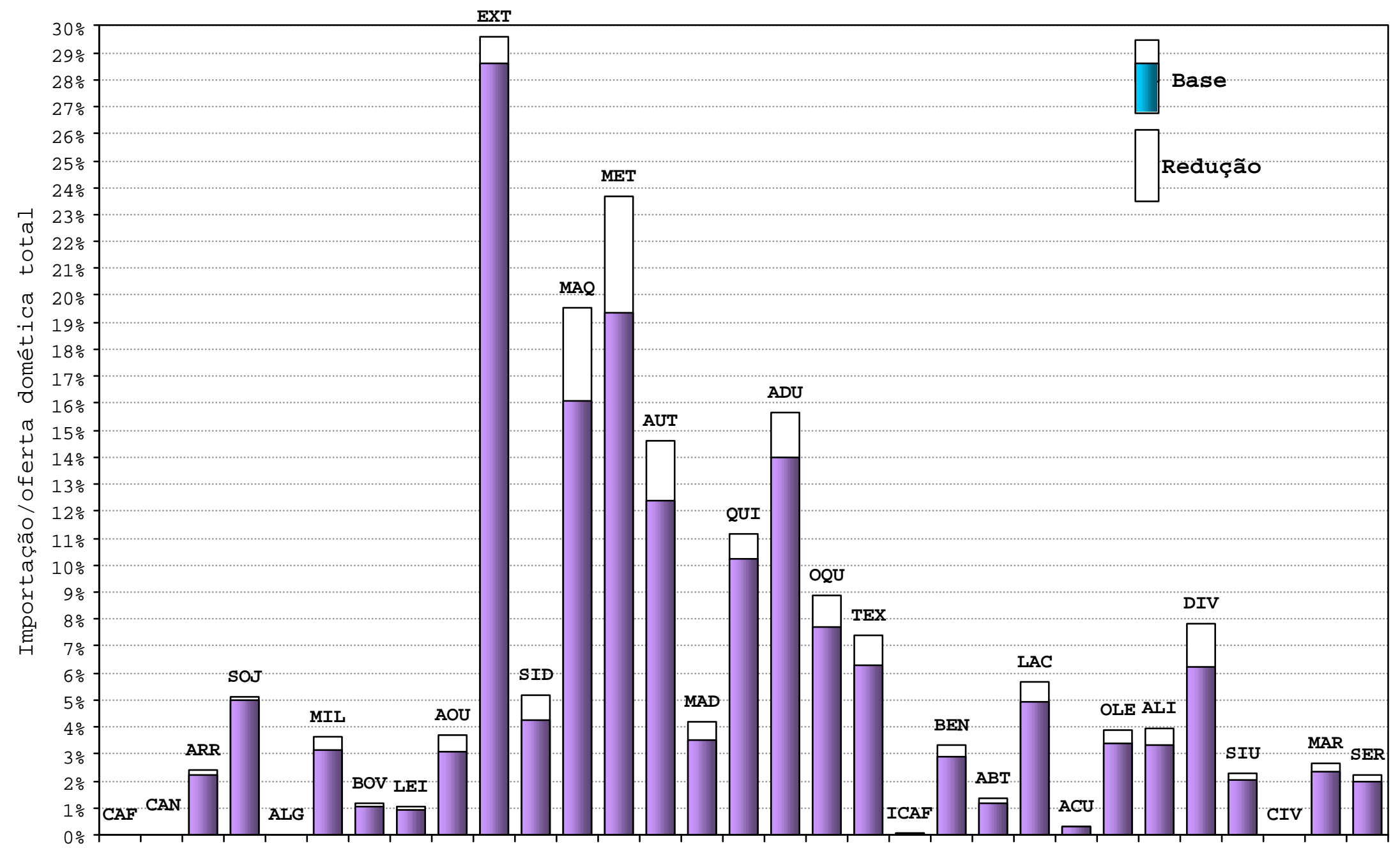

Figura 23 - Participação das importações com relação à oferta composta doméstica e o impacto da desvalorização da taxa de câmbio. 
A resposta à desvalorização por parte do volume importado pelos setores, pode ser observada na Figura 24. Com exceção do setor algodão, todos os demais setores apresentaram redução dos volumes importados. A redução mais acentuada ocorreu nos setores Material Elétrico, Máquinas/tratores e Indústrias Diversas, todos com percentuais de redução total acima de $20 \%$. Com relação aos setores Químicos, Adubos e Outros químicos, observou-se redução inferior, 8,8\%, 8,9\% e $13 \%$ respectivamente. Os setores do grupo agropecuário apresentaram redução de importações, o que no entanto, ocorreu sobre uma base relativamente pequena. O mesmo comportamento foi observado para os setores do grupo agroindustrial.

\subsection{Impacto da desvalorização do câmbio sobre a produção doméstica}

Dando continuidade ao rastreamento do impacto promovido pela desvalorização de $11,33 \%$ da taxa de câmbio nominal, observou-se o comportamento da produção doméstica, que foi influenciada diretamente através da modificação do preço para a produção, decorrente da alteração dos preços domésticos vis-à-vis os preços de exportação. Ao mesmo tempo, existe a influência indireta da alteração dos preços compostos, que originam o custo de produção e foram afetados pela modificação da relação preços domésticos vis-à-vis preços dos importados. As inter-relações de preços no modelo foram apresentadas na Figura 17 e devem ser recordadas para o melhor entendimento dos resultados.

Com relação à estrutura de modelagem adotada, deve-se destacar que as modificações na produção são mais características de curto prazo, uma vez que a composição entre consumo intermediário e valor adicionado foi definida por uma estrutura Leontief (proporções fixas). 


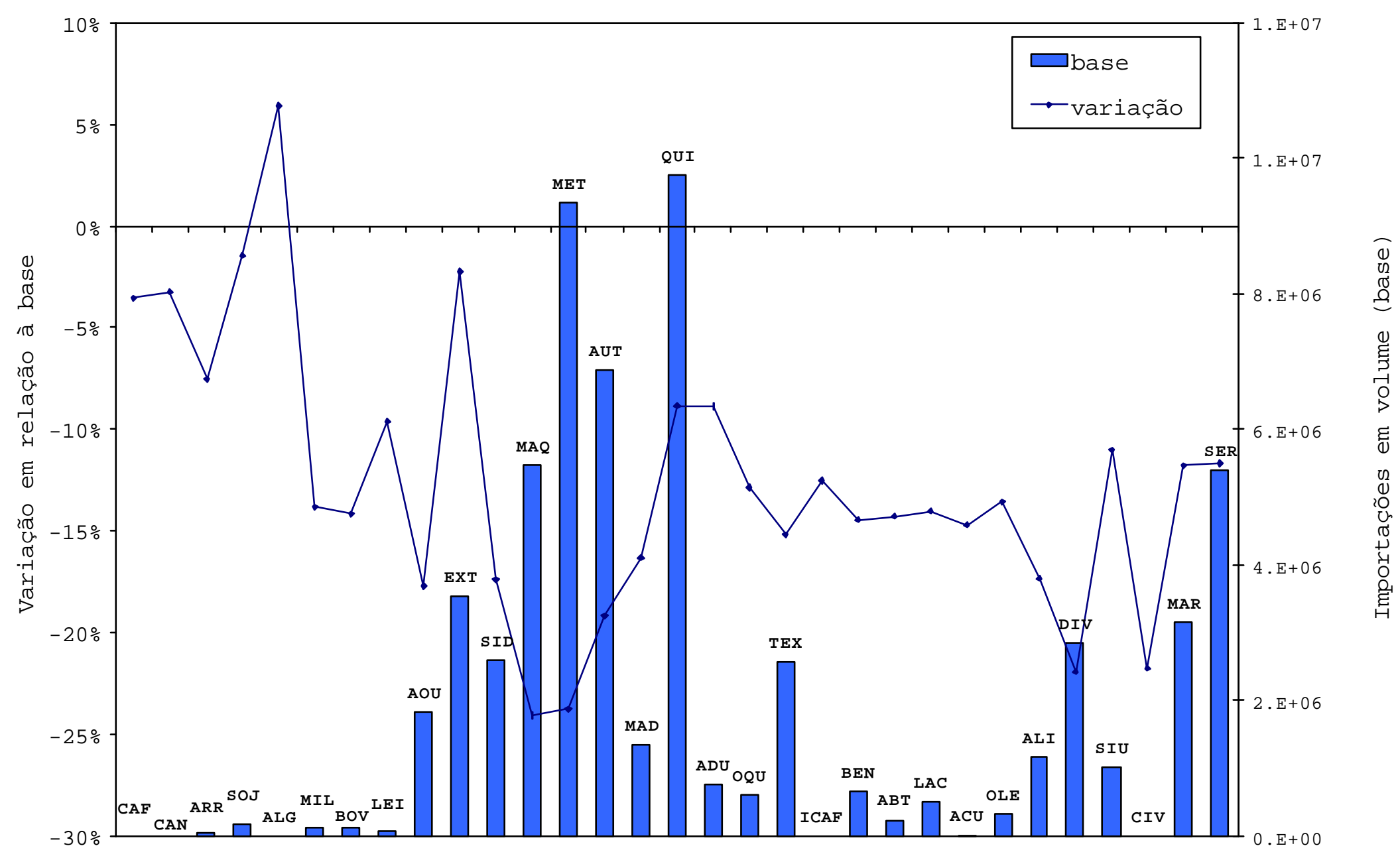

Figura 24 - Efeito da desvalorização sobre as importações por setor. 
Dentro do consumo intermediário de cada setor, as proporções de consumo entre os setores fornecedores são fixas, ou seja, assume-se a não ocorrência de substituição do padrão tecnológico adotado no consumo intermediário. Concomitantemente para o valor adicionado, através da estrutura Cobb-Douglas, tem fixa a proporção em valor do capital e do trabalho, como também define-se os seus rendimentos como sendo constantes de escala. As modificações na produção ocorrem, então, pela realocação do trabalho, sendo o capital fixo em volume ajustado em valor para a manutenção das proporções originais.

Diferentemente da reação das relações externas, que foram afetadas pela modificação uniforme do preço de exportação e do preço de importação para todos os setores, a produção doméstica foi afetada pela modificação dos preços para a produção na medida em que o destino fosse o mercado doméstico ou o externo, e do montante de impostos indiretos pagos. Ao mesmo tempo, o efeito sobre os custos de produção, causado pela modificação dos preços compostos, variou entre os setores na medida da proporção da origem do insumo entre mercado doméstico e externo (importação).

Na Figura 25, apresenta-se a choque resultante sobre o preço para a produção. A análise das informações apresentadas permitiu identificar o estímulo final de preço ocorrido para cada setor da economia brasileira. Os setores Soja e Café destinam parte de sua produção para exportações e, assim sendo, absorveram o estímulo advindo da alta dos preços de exportação. Além do efeito direto os dois setores também receberam o efeito indireto advindo da sua relação com as agroindústrias Fabricação de Óleos Vegetais e Indústrias do Café. Segundo dados das Tabelas 5 e 7, 43\% do consumo intermediário da Indústria de Óleos Vegetais originou-se do setor Soja, sendo esse valor correspondente a $88 \%$ da produção de soja destinada para consumo intermediário. O setor Café atendeu a 55\% do consumo intermediário da Indústria do Café (Tabela 5), o que correspondeu a $61 \%$ do total de consumo intermediário de café (Tabela 7).

Por outro lado, cana-de-açúcar, arroz, algodão e milho apresentaram pequena parcela destinada às exportações, mas receberam também um significativo estímulo de preço. Pode-se explicar esse fato pelo efeito indireto do aumento da demanda por esses produtos advinda dos setores agroindustriais, estes sim mais voltados para a exportação. 
O setor Cana-de-açúcar se relacionou com os setores da agroindústria do Açúcar e da Indústria Química, sendo este último responsável por $51 \%$ do consumo intermediário total de cana-de-açúcar, conforme pode ser observado na Tabela 7. Essa relação gerou um importante efeito indireto. A grande participação da Indústria Química no consumo intermediário da produção de cana-de-açúcar, está associada à classificação adotada pelo IBGE que atribui a produção de álcool anidro ao setor da Indústria Química e não à agroindústria do Açúcar.

O setor Arroz relacionou-se com a agroindústria de Beneficiamento da Produção Vegetal, cujo consumo intermediário representou $90 \%$ do total de consumo intermediário de Arroz (Tabela 7). O setor Algodão relacionou-se com a agroindústria Têxtil, que demandou $96 \%$ do montante destinado ao consumo intermediário por esse setor. Desta forma esses dois setores da agropecuária receberam estímulos indiretos em função da sua relação com agroindústrias, que possuem maior relação com o setor externo. Para o caso do setor Milho, o estímulo de preço ocorrido adveio de uma relação mais pulverizada com os setores agropecuários (bovinos/suínos e outros da agropecuária) e com os setores agroindustriais (Beneficiamento da produção vegetal e Outros produtos alimentares), sendo estes últimos possuidores de uma menor, mas não desconsiderável, produção para exportação. 


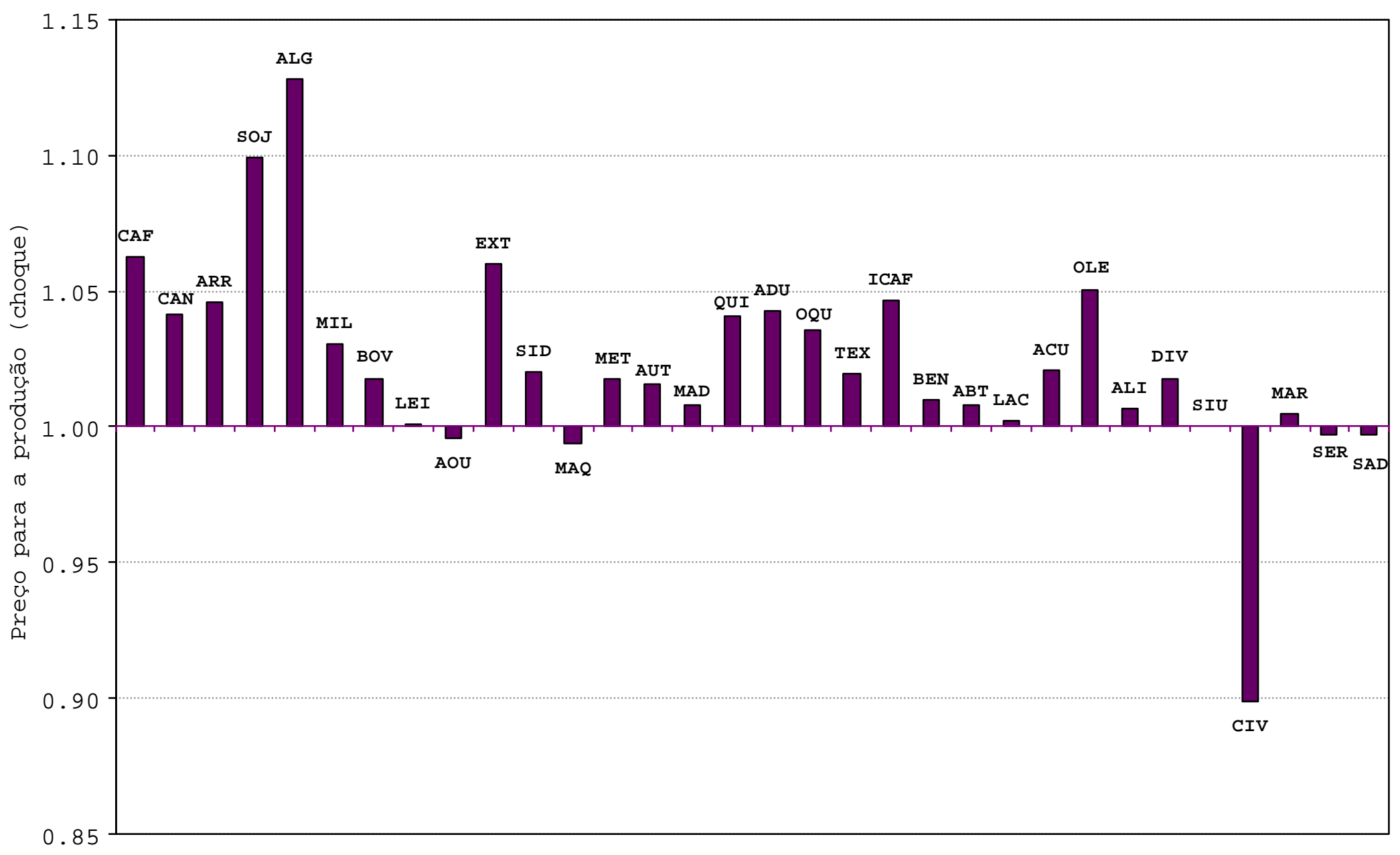

Figura 25 - Impacto da desvalorização sobre o preço para a produção setorial. 
No caso dos setores Bovinos/suínos e Leite natural, o efeito foi relativamente menor que o observado para os setores já analisados. Em primeiro lugar, apresentaram pequena parcela da produção destinada para exportações. Em segundo lugar, estavam conectados com setores agroindustriais com pequena participação no setor externo: os Bovinos e suínos com a Indústria do Abate de animais, com pouco mais de $7 \%$ da produção exportada; e o Leite Natural com a Indústria de laticínios, com menos de 0,1\% da produção exportada (conforme foi apresentado na Figura 21).

O setor Outros da agropecuária recebeu um estímulo de preço negativo, acompanhando o resultado dos setores Máquinas/tratores, Construção Civil, Serviços, e Administração pública. Com exceção do setor de Máquinas/tratores, o setor Outros da agropecuária recebeu um efeito igual ao da Construção Civil, Serviços e Administração pública, setores tipicamente non-tradables. A desvalorização da taxa de câmbio melhorou os preços relativos no sentido dos setores tradables, fazendo com que os setores non-tradables fossem por ela prejudicados.

No grupo agropecuário há os setores tipicamente tradables, de exportação (café, cana, soja) e os substitutos de importação (arroz, algodão, milho e bovinos/suínos e leite natural). Os setores non-tradables da agropecuária brasileira foram todos tratados no setor Outros da agropecuária, muito embora tenha-se também alguns tradables nele incorporados (laranja, aves, trigo, silvicultura, entre outros). Estimou-se a partir do Censo Agropecuário (IBGE, 1997), que as culturas tradables incorporadas dentro do setor Outros da agropecuária representavam aproximadamente $27 \%$ do valor da produção. O resultado obtido indicou que o componente non-tradable incluso no setor Outros da agropecuária superou o componente tradable.

No que diz respeito à conexão com os setores agroindustriais, como mostram as Tabelas 5 e 7, percebe-se que o setor Outros da Agropecuária conecta-se com várias agroindústrias, em especial com a Indústria do Beneficiamento da produção vegetal, responsável por $27 \%$ do total destinado para consumo intermediário pelo setor 
Tabela 5. Participação percentual do setor i (linha) no consumo intermediário do setor j (coluna).

\begin{tabular}{|c|c|c|c|c|c|c|c|c|c|c|c|c|c|c|c|c|c|c|c|c|c|c|c|c|c|c|c|c|c|c|c|c|}
\hline & $\overline{\mathrm{AF}}$ & CAN & ARR & SOJ & ALG & MIL & $\mathrm{BOV}$ & LEI & AOU & EXT & SID & MAQ & $\mathrm{MET}$ & AUT $\mathrm{M}$ & $\mathrm{MAD}$ & $\overline{Q U I A}$ & $\overline{A D U}$ & $\overline{\mathrm{OQU}}$ & TEX & ICAF & BEN & $\overline{A B T} I$ & LAC & $\mathrm{ACU}$ & OLE $A$ & ALI & DIV & SIU & CIV & MAR & SER S & SAD \\
\hline $\mathrm{CAF}$ & 63 & 0 & 0 & 0 & 0 & 0 & 0 & 0 & 0 & 0 & 0 & 0 & 0 & 0 & 0 & 0 & 0 & 0 & 0 & 55 & 0 & 0 & 0 & 0 & 0 & 0 & 0 & 0 & 0 & 0 & 0 & 0 \\
\hline CAN & 0 & 12 & 0 & 0 & 0 & 0 & 0 & 0 & 0 & 0 & 0 & 0 & 0 & 0 & 0 & 5 & 0 & 0 & 0 & 0 & 0 & 0 & 0 & 40 & 0 & 1 & 0 & 0 & 0 & 0 & 0 & \\
\hline ARR & 0 & 0 & 18 & 0 & 0 & 0 & 0 & 0 & 0 & 0 & 0 & 0 & 0 & 0 & 0 & 0 & 0 & 0 & 0 & 0 & 11 & 0 & 0 & 0 & 0 & 0 & 0 & 0 & 0 & 0 & 0 & 0 \\
\hline SOJ & 0 & 0 & 0 & 10 & 0 & 0 & 0 & 0 & 0 & 0 & 0 & 0 & 0 & 0 & 0 & 0 & 0 & 0 & 0 & 0 & 1 & 0 & 0 & 0 & 43 & 1 & 0 & 0 & 0 & 0 & 0 & 0 \\
\hline ALG & 0 & 0 & 0 & 0 & 9 & 0 & 0 & 0 & 0 & 0 & 0 & 0 & 0 & 0 & 0 & 0 & 0 & 0 & 2 & 0 & 0 & 0 & 0 & 0 & 0 & 0 & 0 & 0 & 0 & 0 & 0 & 0 \\
\hline MIL & 0 & 0 & 0 & 0 & 0 & 3 & 34 & 1 & 9 & 0 & 0 & 0 & 0 & 0 & 0 & 0 & 0 & 0 & 0 & 0 & 3 & 0 & 0 & 0 & 0 & 7 & 0 & 0 & 0 & 0 & 0 & 0 \\
\hline BOV & 0 & 0 & 0 & 0 & 0 & 0 & 26 & 0 & 0 & 0 & 0 & 0 & 0 & 0 & 0 & 0 & 0 & 0 & 0 & 0 & 0 & 51 & 0 & 0 & 0 & 0 & 0 & 0 & 0 & 0 & 0 & 0 \\
\hline LEI & 0 & 0 & 0 & 0 & 0 & 0 & 0 & 32 & 0 & 0 & 0 & 0 & 0 & 0 & 0 & 0 & 0 & 0 & 0 & 0 & 0 & 0 & 56 & 0 & 0 & 0 & 0 & 0 & 0 & 0 & 0 & 0 \\
\hline AOU & 0 & 0 & 0 & 0 & 0 & 0 & 0 & 0 & 45 & 0 & 2 & 0 & 0 & 0 & 12 & 0 & 1 & 1 & 2 & 0 & 51 & 16 & 0 & 0 & 5 & 10 & 3 & 0 & 0 & 0 & 2 & 3 \\
\hline $\mathrm{EXT}$ & 1 & 2 & 1 & 1 & 1 & 1 & 0 & 1 & 1 & 11 & 6 & 0 & 0 & 0 & 0 & 17 & 2 & 1 & 0 & 0 & 0 & 0 & 0 & 0 & 0 & 1 & 5 & 0 & 1 & 0 & 0 & 0 \\
\hline SID & 0 & 1 & 1 & 1 & 1 & 1 & 0 & 1 & 0 & 9 & 59 & 41 & 20 & 23 & 3 & 2 & 5 & 4 & 1 & 0 & 2 & 1 & 1 & 1 & 3 & 2 & 5 & 1 & 18 & 1 & 1 & 0 \\
\hline MAQ & 0 & 1 & 2 & 1 & 1 & 2 & 0 & 1 & 1 & 12 & 4 & 12 & 7 & 6 & 3 & 3 & 1 & 1 & 2 & 0 & 1 & 1 & 1 & 7 & 1 & 1 & 3 & 5 & 3 & 1 & 1 & 1 \\
\hline MET & 0 & 0 & 0 & 0 & 0 & 0 & 0 & 0 & 0 & 1 & 1 & 8 & 37 & 1 & 0 & 0 & 0 & 0 & 0 & 0 & 0 & 0 & 0 & 1 & 0 & 0 & 1 & 5 & 7 & 0 & 1 & 1 \\
\hline AUT & 0 & 0 & 0 & 0 & 0 & 0 & 0 & 0 & 0 & 0 & 0 & 4 & 1 & 42 & 0 & 0 & 0 & 0 & 0 & 0 & 0 & 0 & 0 & 0 & 0 & 0 & 0 & 1 & 0 & 5 & 3 & 1 \\
\hline MAD & 0 & 0 & 1 & 0 & 0 & 1 & 0 & 0 & 1 & 2 & 1 & 2 & 4 & 2 & 37 & 2 & 2 & 2 & 2 & 1 & 3 & 1 & 1 & 2 & 1 & 5 & 4 & 1 & 6 & 4 & 4 & 6 \\
\hline QUI & 5 & 14 & 19 & 14 & 13 & 15 & 2 & 14 & 6 & 9 & 5 & 6 & 9 & 5 & 13 & 47 & 6 & 57 & 12 & 1 & 3 & 2 & 3 & 4 & 3 & 5 & 19 & 3 & 10 & 32 & 2 & 5 \\
\hline $\mathrm{ADU}$ & 13 & 22 & 17 & 32 & 21 & 31 & 1 & 5 & 7 & 0 & 0 & 0 & 0 & 0 & 0 & 0 & 60 & 0 & 0 & 0 & 0 & 0 & 0 & 0 & 0 & 0 & 0 & 0 & 0 & 0 & 0 & 0 \\
\hline OQU & 5 & 8 & 12 & 17 & 23 & 15 & 2 & 12 & 5 & 4 & 1 & 0 & 0 & 0 & 1 & 2 & 0 & 13 & 1 & 0 & 0 & 0 & 0 & 1 & 0 & 2 & 1 & 0 & 0 & 0 & 0 & 1 \\
\hline TEX & 1 & 0 & 1 & 0 & 0 & 1 & 0 & 0 & 1 & 0 & 0 & 1 & 0 & 1 & 1 & 0 & 0 & 0 & 59 & 0 & 1 & 0 & 0 & 5 & 2 & 0 & 3 & 0 & 0 & 1 & 1 & 1 \\
\hline ICAF & 0 & 0 & 0 & 0 & 0 & 0 & 0 & 0 & 0 & 0 & 0 & 0 & 0 & 0 & 0 & 0 & 0 & 0 & 0 & 35 & 0 & 0 & 0 & 0 & 0 & 0 & 0 & 0 & 0 & 0 & 0 & 0 \\
\hline BEM & 0 & 0 & 0 & 0 & 0 & 0 & 0 & 0 & 0 & 0 & 0 & 0 & 0 & 0 & 0 & 0 & 0 & 1 & 0 & 0 & 4 & 0 & 1 & 0 & 2 & 18 & 0 & 0 & 0 & 0 & 1 & 1 \\
\hline $\mathrm{ABT}$ & 0 & 0 & 0 & 0 & 0 & 0 & 0 & 0 & 0 & 0 & 0 & 0 & 0 & 0 & 0 & 0 & 0 & 0 & 2 & 0 & 0 & 13 & 0 & 0 & 1 & 1 & 0 & 0 & 0 & 0 & 1 & . \\
\hline LAC & 0 & 0 & 0 & 0 & 0 & 0 & 0 & 0 & 0 & 0 & 0 & 0 & 0 & 0 & 0 & 0 & 0 & 0 & 0 & 0 & 0 & 0 & 27 & 0 & 0 & 1 & 0 & 0 & 0 & 0 & 0 & 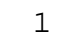 \\
\hline $\mathrm{ACU}$ & 0 & 0 & 0 & 0 & 0 & 0 & 0 & 0 & 0 & 0 & 0 & 0 & 0 & 0 & 0 & 1 & 0 & 0 & 0 & 0 & 1 & 0 & 1 & 22 & 0 & 4 & 0 & 0 & 0 & 0 & 1 & 0 \\
\hline OLE & 0 & 0 & 0 & 0 & 0 & 1 & 6 & 3 & 2 & 0 & 0 & 0 & 0 & 0 & 0 & 2 & 0 & 4 & 0 & 0 & 1 & 0 & 0 & 0 & 23 & 9 & 0 & 0 & 0 & 0 & 0 & 0 \\
\hline ALI & 1 & 1 & 1 & 1 & 1 & 2 & 21 & 10 & 14 & 0 & 0 & 0 & 0 & 0 & 0 & 0 & 0 & 0 & 0 & 0 & 0 & 1 & 0 & 0 & 0 & 9 & 0 & 0 & 0 & 0 & 5 & 0 \\
\hline DIV & 0 & 1 & 1 & 1 & 1 & 1 & 0 & 1 & 0 & 4 & 3 & 4 & 4 & 6 & 2 & 2 & 2 & 2 & 2 & 1 & 1 & 0 & 0 & 1 & 0 & 2 & 34 & 1 & 28 & 3 & 4 & \\
\hline
\end{tabular}


Tabela 5. Participação percentual do setor i (linha) no consumo intermediário do setor j (coluna).

\begin{tabular}{|c|c|c|c|c|c|c|c|c|c|c|c|c|c|c|c|c|c|c|c|c|c|c|c|c|c|c|c|c|c|c|c|c|c|}
\hline & CAF & CAN & $\overline{A R R}$ & SOJ & $\overline{\mathrm{ALG} \mathrm{N}}$ & MIL & $\mathrm{BOV}$ & LEI & $\overline{\mathrm{AOU}}$ & EXT & SID & MAQ & $\mathrm{MET}$ & AUT N & $\mathrm{MAD}$ & QUI & $\mathrm{ADU}$ & $O Q U$ & TEX & ICAF & & $\mathrm{EN} \mathrm{A}$ & $\mathrm{ABT} I$ & LAC & $\overline{A C U}$ & OLE & $\overline{A L I ~ D}$ & $\overline{\mathrm{DIV} S}$ & SIU & CIV N & MAR & SER & $\overline{\mathrm{SAD}}$ \\
\hline SIU & 1 & 1 & 3 & 1 & 1 & 2 & 0 & 2 & 1 & 8 & 5 & 4 & 2 & 2 & 5 & 3 & 2 & 1 & 2 & & 1 & 2 & 2 & 1 & 3 & 1 & 3 & 4 & 63 & 1 & 5 & 4 & $\overline{9}$ \\
\hline CIV & 0 & 0 & 0 & 0 & 0 & 0 & 0 & 0 & 0 & 1 & 0 & 1 & 0 & 0 & 0 & 0 & 0 & 0 & 0 & & 0 & 0 & 0 & 0 & 1 & 0 & 0 & 0 & 1 & 9 & 1 & 3 & 2 \\
\hline MAR & 5 & 23 & 14 & 15 & 16 & 16 & 6 & 9 & 3 & 15 & 7 & 9 & 9 & 7 & 12 & 8 & 9 & 7 & 8 & 3 & $\begin{array}{ll}4 & 1\end{array}$ & 11 & 8 & 4 & 8 & 10 & 11 & 10 & 3 & 11 & 21 & 8 & 12 \\
\hline SER & 3 & 11 & 9 & 4 & 9 & 7 & 1 & 5 & 3 & 21 & 4 & 6 & 6 & 4 & 5 & 4 & 5 & 4 & 4 & 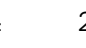 & 2 & 3 & 3 & 2 & 4 & 3 & 5 & 7 & 14 & 4 & 24 & 56 & 45 \\
\hline $\mathrm{SAD}$ & 1 & 2 & 1 & 2 & 2 & 2 & 0 & 1 & 1 & 2 & 0 & 1 & 1 & 1 & 5 & 1 & 4 & 1 & 1 & . & 0 & 1 & 0 & 0 & 1 & 0 & 1 & 1 & 1 & 1 & 2 & 2 & 6 \\
\hline
\end{tabular}


Tabela 6. Participação percentual do setor i (linha) no consumo intermediário do setor j (coluna), para i $\neq$ j (extra setor).

\begin{tabular}{|c|c|c|c|c|c|c|c|c|c|c|c|c|c|c|c|c|c|c|c|c|c|c|c|c|c|c|c|c|c|c|c|c|}
\hline & $\mathrm{CAF}$ & CAN & $\overline{A R R}$ & $\mathrm{SOJ}$ & $\overline{A L G}$ & MIL & $\mathrm{BOV}$ & LEI & $\overline{\mathrm{AOU}}$ & EXT & SID & MAQ & MET & AUT & MAD & QUI & $\mathrm{ADU}$ & $\mathrm{OQU}$ & TEX & ICAF & BEN & $\mathrm{ABT}$ & LAC & $\mathrm{ACU}$ & OLE & ALI & DIV & SIU & $\mathrm{J}$ CIV & MAR & SER & SAD \\
\hline $\mathrm{CAF}$ & - & 0 & 0 & 0 & 0 & 0 & 0 & 0 & 0 & 0 & 0 & 0 & 0 & 0 & 0 & 0 & 0 & 0 & 0 & 84 & 0 & 0 & 0 & 0 & 0 & 0 & 0 & 0 & 0 & 0 & 0 & 0 \\
\hline CAN & 0 & - & 0 & 0 & 0 & 0 & 0 & 0 & 0 & 0 & 0 & 0 & 0 & 0 & 0 & 10 & 0 & 0 & 0 & 0 & 0 & 0 & 0 & 51 & 0 & 1 & 0 & 0 & 0 & 0 & 0 & 0 \\
\hline ARR & 0 & 0 & - & 0 & 0 & 0 & 0 & 0 & 0 & 0 & 0 & 0 & 0 & 0 & 0 & 0 & 0 & 0 & 0 & 0 & 12 & 0 & 0 & 0 & 0 & 0 & 0 & 0 & 0 & 0 & 0 & 0 \\
\hline SOJ & 0 & 0 & 0 & - & 0 & 0 & 0 & 0 & 0 & 0 & 0 & 0 & 0 & 0 & 0 & 0 & 0 & 0 & 0 & 0 & 1 & 0 & 0 & 0 & 56 & 1 & 0 & 0 & 0 & 0 & 0 & 0 \\
\hline ALG & 0 & 0 & 0 & 0 & - & 0 & 0 & 0 & 0 & 0 & 0 & 0 & 0 & 0 & 0 & 0 & 0 & 0 & 5 & 0 & 0 & 0 & 0 & 0 & 0 & 0 & 0 & 0 & 0 & 0 & 0 & 0 \\
\hline MIL & 0 & 0 & 0 & 0 & 0 & - & 46 & 1 & 17 & 0 & 0 & 0 & 0 & 0 & 0 & 0 & 0 & 0 & 0 & 0 & 3 & 0 & 0 & 0 & 0 & 7 & 0 & 0 & 0 & 0 & 0 & 0 \\
\hline $\mathrm{BOV}$ & 0 & 0 & 0 & 0 & 0 & 0 & - & 0 & 0 & 0 & 0 & 0 & 0 & 0 & 0 & 0 & 0 & 0 & 0 & 0 & 0 & 58 & 0 & 0 & 0 & 0 & 0 & 0 & 0 & 0 & 0 & 0 \\
\hline LEI & 0 & 0 & 0 & 0 & 0 & 0 & 0 & - & 0 & 0 & 0 & 0 & 0 & 0 & 0 & 0 & 0 & 0 & 0 & 0 & 0 & 0 & 76 & 0 & 0 & 0 & 0 & 0 & 0 & 0 & 0 & 0 \\
\hline $\mathrm{AOU}$ & 0 & 0 & 0 & 0 & 0 & 0 & 0 & 0 & - & 0 & 6 & 0 & 0 & 0 & 18 & 0 & 3 & 1 & 5 & 0 & 53 & 19 & 0 & 0 & 7 & 11 & 4 & 0 & 0 & 0 & 4 & 4 \\
\hline $\mathrm{EXT}$ & 2 & 2 & 1 & 1 & 1 & 1 & 1 & 2 & 1 & - & 15 & 0 & 1 & 0 & 0 & 32 & 4 & 2 & 0 & 0 & 0 & 0 & 0 & 0 & 0 & 1 & 8 & 1 & 1 & 0 & 0 & 0 \\
\hline SID & 1 & 1 & 1 & 1 & 1 & 1 & 0 & 1 & 1 & 10 & - & 47 & 32 & 39 & 4 & 3 & 12 & 5 & 2 & 0 & 2 & 1 & 2 & 2 & 4 & 2 & 8 & 2 & 20 & 1 & 1 & 0 \\
\hline MAQ & 1 & 1 & 2 & 2 & 2 & 2 & 0 & 2 & 1 & 13 & 11 & - & 10 & 11 & 4 & 5 & 4 & 1 & 4 & 0 & 1 & 1 & 1 & 10 & 1 & 1 & 4 & 14 & 3 & 1 & 1 & 1 \\
\hline $\mathrm{MET}$ & 0 & 0 & 0 & 0 & 0 & 0 & 0 & 0 & 0 & 1 & 2 & 9 & - & 2 & 0 & 0 & 1 & 0 & 0 & 0 & 0 & 0 & 0 & 1 & 0 & 0 & 1 & 15 & 8 & 0 & 2 & 1 \\
\hline AUT & 0 & 0 & 0 & 0 & 0 & 0 & 0 & 0 & 0 & 1 & 1 & 5 & 1 & - & 0 & 0 & 0 & 0 & 0 & 0 & 0 & 0 & 0 & 0 & 0 & 0 & 0 & 2 & 0 & 6 & 7 & 2 \\
\hline MAD & 1 & 0 & 1 & 0 & 0 & 1 & 0 & 1 & 1 & 2 & 3 & 2 & 6 & 3 & - & 4 & 6 & 2 & 5 & 1 & 3 & 1 & 2 & 2 & 2 & 5 & 6 & 2 & 6 & 4 & 8 & 6 \\
\hline QUI & 13 & 17 & 23 & 15 & 14 & 16 & 2 & 21 & 11 & 10 & 13 & 7 & 14 & 9 & 20 & - & 15 & 66 & 30 & 2 & 3 & 2 & 4 & 5 & 3 & 6 & 28 & 7 & 11 & 41 & 5 & 5 \\
\hline $\mathrm{ADU}$ & 36 & 25 & 21 & 36 & 23 & 32 & 1 & 8 & 13 & 0 & 0 & 0 & 0 & 0 & 0 & 0 & - & 0 & 0 & 0 & 0 & 0 & 0 & 0 & 0 & 0 & 0 & 0 & 0 & 0 & 0 & 0 \\
\hline $\mathrm{OQU}$ & 12 & 9 & 15 & 19 & 25 & 15 & 2 & 18 & 10 & 4 & 2 & 0 & 0 & 0 & 2 & 3 & 0 & - & 2 & 0 & 0 & 0 & 0 & 1 & 0 & 2 & 2 & 0 & 0 & 0 & 1 & 1 \\
\hline TEX & 2 & 0 & 1 & 0 & 0 & 1 & 0 & 0 & 2 & 1 & 0 & 1 & 0 & 1 & 2 & 1 & 1 & 0 & - & 1 & 1 & 0 & 0 & 6 & 3 & 0 & 4 & 0 & 0 & 1 & 3 & 1 \\
\hline ICAF & 0 & 0 & 0 & 0 & 0 & 0 & 0 & 0 & 0 & 0 & 0 & 0 & 0 & 0 & 0 & 0 & 0 & 0 & 0 & - & 0 & 0 & 0 & 0 & 0 & 0 & 0 & 0 & 0 & 0 & 1 & 0 \\
\hline $\mathrm{BEN}$ & 0 & 0 & 0 & 0 & 0 & 0 & 0 & 0 & 0 & 0 & 0 & 0 & 0 & 0 & 0 & 0 & 0 & 1 & 0 & 0 & - & 0 & 1 & 0 & 3 & 20 & 0 & 0 & 0 & 0 & 1 & 1 \\
\hline $\mathrm{ABT}$ & 0 & 0 & 0 & 0 & 0 & 0 & 0 & 0 & 0 & 0 & 0 & 0 & 0 & 0 & 0 & 0 & 0 & 0 & 5 & 0 & 0 & - & 0 & 0 & 1 & 1 & 0 & 0 & 0 & 0 & 3 & 1 \\
\hline LAC & 0 & 0 & 0 & 0 & 0 & 0 & 0 & 0 & 0 & 0 & 0 & 0 & 0 & 0 & 0 & 0 & 0 & 0 & 0 & 0 & 0 & 0 & - & 0 & 0 & 1 & 0 & 0 & 0 & 0 & 1 & 1 \\
\hline $\mathrm{ACU}$ & 0 & 0 & 0 & 0 & 0 & 0 & 0 & 0 & 0 & 0 & 0 & 0 & 0 & 0 & 0 & 2 & 0 & 0 & 0 & 0 & 1 & 0 & 1 & - & 0 & 4 & 0 & 0 & 0 & 0 & 1 & 0 \\
\hline OLE & 0 & 0 & 0 & 0 & 0 & 1 & 9 & 4 & 3 & 0 & 0 & 0 & 0 & 0 & 0 & 3 & 0 & 5 & 0 & 0 & 1 & 0 & 1 & 0 & - & 9 & 0 & 0 & 0 & 0 & 1 & 0 \\
\hline ALI & 2 & 1 & 1 & 1 & 1 & 2 & 28 & 15 & 24 & 0 & 0 & 0 & 0 & 0 & 0 & 0 & 0 & 0 & 0 & 0 & 0 & 1 & 0 & 0 & 0 & - & 0 & 0 & 0 & 1 & 12 & 0 \\
\hline DIV & 1 & 1 & 1 & 1 & 1 & 1 & 0 & 1 & 1 & 5 & 8 & 5 & 6 & 10 & 4 & 3 & 5 & 2 & 5 & 1 & 1 & 0 & 1 & 2 & 0 & 3 & - & 3 & 31 & 3 & 9 & 4 \\
\hline SIU & 2 & 1 & 3 & 1 & 1 & 2 & 1 & 3 & 2 & 9 & 11 & 5 & 3 & 3 & 7 & 6 & 4 & 2 & 6 & 1 & 2 & 2 & 2 & 4 & 2 & 3 & 6 & - & 1 & 6 & 9 & 10 \\
\hline
\end{tabular}


Tabela 6. Participação percentual do setor i (linha) no consumo intermediário do setor $\mathrm{j}$ (coluna), para $\mathrm{i} \neq \mathrm{j}$ (extra setor).

\begin{tabular}{|c|c|c|c|c|c|c|c|c|c|c|c|c|c|c|c|c|c|c|c|c|c|c|c|c|c|c|c|c|c|c|c|c|}
\hline & $\overline{C A F}$ & CAN & ARR & $\mathrm{SOJ}$ & $\overline{A L G}$ & MIL & $\overline{\mathrm{BOV}}$ & LEI & $\overline{\mathrm{AOU}}$ & EXT & SID & MAQ & MET & AUT & MAD & QUI & ADU & OQU & TEX & ICAF & $\overline{B E N}$ & $\mathrm{ABT}$ & LAC & $\overline{\mathrm{ACU}}$ & OLE & ALI & DIV & SIU & CIV & MAR & SER & SAD \\
\hline CIV & 0 & 0 & 0 & 0 & 0 & 0 & 0 & 0 & 0 & 1 & 1 & 1 & 0 & 0 & 1 & 1 & 1 & 0 & 0 & 0 & 0 & 0 & 0 & 1 & 0 & 0 & 0 & 3 & - & 1 & 8 & 2 \\
\hline MAR & 14 & 27 & 17 & 16 & 17 & 16 & 8 & 13 & 6 & 16 & 17 & 11 & 15 & 12 & 19 & 16 & 22 & 9 & 20 & 6 & 11 & 9 & 6 & 10 & 13 & 13 & 14 & 9 & 12 & - & 18 & 13 \\
\hline SER & 9 & 12 & 11 & 5 & 10 & 7 & 1 & 8 & 5 & 24 & 9 & 7 & 9 & 7 & 9 & 8 & 13 & 4 & 9 & 3 & 3 & 3 & 3 & 5 & 4 & 5 & 11 & 38 & 5 & 30 & - & 47 \\
\hline SAD & 3 & 3 & 2 & 2 & 3 & 2 & 0 & 2 & 2 & 2 & 1 & 1 & 1 & 1 & 8 & 1 & 9 & 1 & 1 & 0 & 1 & 0 & 1 & 1 & 1 & 1 & 2 & 4 & 1 & 3 & 5 & - \\
\hline
\end{tabular}


Tabela 7. Participação do setor j (coluna) no consumo intermediário da produção do setor i (linha).

\begin{tabular}{|c|c|c|c|c|c|c|c|c|c|c|c|c|c|c|c|c|c|c|c|c|c|c|c|c|c|c|c|c|c|c|c|c|}
\hline & $\mathrm{CAF}$ & CAN & ARR & SOJ & ALG & MIL & $\mathrm{BOV}$ & LEI & $\overline{\mathrm{AOU}}$ & $\mathrm{EXT}$ & SID & MAQ & MET & AUT & MAD & QUI & $\mathrm{ADU}$ & $\mathrm{OQU}$ & TEX & ICAF & $\mathrm{BEN}$ & $\overline{\mathrm{ABT}}$ & LAC & $\overline{A C U}$ & OLE & $\overline{A L I}$ & $\overline{\text { DIV }}$ & $\overline{S I U}$ & CIV & MAR & SER & SAD \\
\hline $\mathrm{CAF}$ & 36 & 0 & 0 & 0 & 0 & 0 & 0 & 0 & 0 & 0 & 0 & 0 & 0 & 0 & 0 & 0 & 0 & 0 & 0 & 61 & 1 & 0 & 0 & 0 & 0 & 0 & 0 & 0 & 0 & 0 & 2 & 0 \\
\hline CAN & 0 & 6 & 0 & 0 & 0 & 0 & 0 & 0 & 0 & 0 & 0 & 0 & 0 & 0 & 0 & 51 & 0 & 0 & 0 & 0 & 0 & 0 & 0 & 38 & 0 & 4 & 0 & 0 & 0 & 0 & 0 & 0 \\
\hline ARR & 0 & 0 & 7 & 0 & 0 & 0 & 0 & 0 & 0 & 0 & 0 & 0 & 0 & 0 & 0 & 0 & 0 & 0 & 0 & 0 & 92 & 0 & 0 & 0 & 0 & 0 & 0 & 0 & 0 & 0 & 0 & 0 \\
\hline SOJ & 0 & 0 & 0 & 6 & 0 & 0 & 0 & 0 & 0 & 0 & 0 & 0 & 0 & 0 & 0 & 0 & 0 & 0 & 0 & 0 & 2 & 0 & 0 & 0 & 88 & 4 & 0 & 0 & 0 & 0 & 0 & 0 \\
\hline ALG & 0 & 0 & 0 & 0 & 4 & 0 & 0 & 0 & 0 & 0 & 0 & 0 & 0 & 0 & 0 & 0 & 0 & 0 & 96 & 0 & 0 & 0 & 0 & 0 & 0 & 0 & 0 & 0 & 0 & 0 & 0 & 0 \\
\hline MIL & 0 & 0 & 0 & 0 & 0 & 1 & 20 & 1 & 38 & 0 & 0 & 0 & 0 & 0 & 0 & 0 & 0 & 0 & 0 & 0 & 10 & 0 & 0 & 0 & 0 & 30 & 0 & 0 & 0 & 0 & 0 & 0 \\
\hline BOV & 0 & 0 & 0 & 0 & 0 & 0 & 8 & 0 & 0 & 0 & 0 & 0 & 0 & 0 & 0 & 0 & 0 & 0 & 0 & 0 & 0 & 90 & 0 & 0 & 0 & 0 & 0 & 0 & 0 & 0 & 1 & 0 \\
\hline LEI & 0 & 0 & 0 & 0 & 0 & 0 & 0 & 29 & 0 & 0 & 0 & 0 & 0 & 0 & 0 & 0 & 0 & 0 & 0 & 0 & 0 & 0 & 67 & 0 & 0 & 1 & 0 & 0 & 0 & 0 & 3 & 0 \\
\hline AOU & 0 & 0 & 0 & 0 & 0 & 0 & 0 & 0 & 28 & 0 & 3 & 0 & 0 & 0 & 9 & 0 & 0 & 0 & 2 & 0 & 27 & 8 & 0 & 0 & 2 & 7 & 2 & 0 & 0 & 0 & 6 & 6 \\
\hline $\mathrm{EXT}$ & 0 & 0 & 0 & 0 & 0 & 0 & 0 & 0 & 1 & 5 & 18 & 0 & 0 & 0 & 0 & 62 & 0 & 1 & 0 & 0 & 0 & 0 & 0 & 0 & 0 & 1 & 7 & 0 & 3 & 0 & 0 & 0 \\
\hline SID & 0 & 0 & 0 & 0 & 0 & 0 & 0 & 0 & 0 & 1 & 45 & 9 & 7 & 12 & 1 & 1 & 0 & 0 & 0 & 0 & 1 & 0 & 0 & 0 & 1 & 1 & 2 & 0 & 15 & 1 & 1 & 0 \\
\hline MAQ & 0 & 0 & 0 & 0 & 0 & 0 & 0 & 0 & 1 & 5 & 12 & 9 & 9 & 12 & 4 & 9 & 0 & 0 & 3 & 0 & 1 & 1 & 0 & 2 & 1 & 2 & 4 & 6 & 8 & 4 & 4 & 3 \\
\hline $\mathrm{MET}$ & 0 & 0 & 0 & 0 & 0 & 0 & 0 & 0 & 0 & 0 & 2 & 6 & 49 & 2 & 0 & 1 & 0 & 0 & 0 & 0 & 0 & 0 & 0 & 0 & 0 & 0 & 1 & 6 & 23 & 1 & 5 & 3 \\
\hline AUT & 0 & 0 & 0 & 0 & 0 & 0 & 0 & 0 & 0 & 0 & 1 & 2 & 0 & 59 & 0 & 0 & 0 & 0 & 0 & 0 & 0 & 0 & 0 & 0 & 0 & 0 & 0 & 1 & 1 & 15 & 16 & 4 \\
\hline MAD & 0 & 0 & 0 & 0 & 0 & 0 & 0 & 0 & 0 & 0 & 2 & 1 & 3 & 2 & 31 & 4 & 0 & 0 & 2 & 0 & 2 & 1 & 0 & 0 & 0 & 3 & 3 & 1 & 10 & 8 & 15 & 11 \\
\hline QUI & 0 & 0 & 0 & 1 & 0 & 0 & 0 & 1 & 1 & 1 & 3 & 1 & 2 & 2 & 4 & 30 & 0 & 4 & 4 & 0 & 1 & 0 & 0 & 0 & 0 & 1 & 4 & 1 & 6 & 25 & 3 & 4 \\
\hline $\mathrm{ADU}$ & 6 & 9 & 2 & 17 & 1 & 5 & 0 & 5 & 22 & 0 & 0 & 0 & 0 & 0 & 0 & 2 & 30 & 0 & 0 & 0 & 0 & 0 & 0 & 0 & 0 & 0 & 0 & 0 & 0 & 0 & 0 & 0 \\
\hline $\mathrm{OQU}$ & 2 & 3 & 1 & 8 & 1 & 2 & 1 & 9 & 14 & 3 & 5 & 0 & 1 & 1 & 4 & 11 & 0 & 10 & 3 & 0 & 0 & 0 & 0 & 0 & 1 & 4 & 3 & 0 & 1 & 1 & 4 & 6 \\
\hline TEX & 0 & 0 & 0 & 0 & 0 & 0 & 0 & 0 & 1 & 0 & 0 & 0 & 0 & 1 & 1 & 1 & 0 & 0 & 75 & 0 & 0 & 0 & 0 & 1 & 1 & 0 & 3 & 0 & 0 & 2 & 8 & 2 \\
\hline ICAF & 0 & 0 & 0 & 0 & 0 & 0 & 0 & 0 & 0 & 0 & 0 & 0 & 0 & 0 & 0 & 0 & 0 & 0 & 0 & 74 & 0 & 0 & 0 & 0 & 0 & 0 & 0 & 0 & 0 & 0 & 23 & 2 \\
\hline BEN & 0 & 0 & 0 & 0 & 0 & 0 & 0 & 0 & 1 & 0 & 0 & 0 & 0 & 0 & 1 & 1 & 0 & 1 & 0 & 0 & 12 & 1 & 1 & 0 & 4 & 61 & 0 & 0 & 0 & 0 & 11 & 6 \\
\hline $\mathrm{ABT}$ & 0 & 0 & 0 & 0 & 0 & 0 & 0 & 0 & 1 & 0 & 0 & 0 & 0 & 0 & 0 & 1 & 0 & 0 & 11 & 0 & 1 & 41 & 0 & 0 & 2 & 5 & 0 & 0 & 0 & 0 & 28 & 10 \\
\hline LAC & 0 & 0 & 0 & 0 & 0 & 0 & 0 & 0 & 0 & 0 & 0 & 0 & 0 & 0 & 0 & 0 & 0 & 0 & 0 & 0 & 1 & 0 & 61 & 0 & 0 & 6 & 0 & 0 & 0 & 0 & 13 & 19 \\
\hline $\mathrm{ACU}$ & 0 & 0 & 0 & 0 & 0 & 0 & 0 & 0 & 0 & 0 & 0 & 0 & 0 & 0 & 0 & 16 & 0 & 0 & 0 & 0 & 4 & 0 & 1 & 33 & 0 & 25 & 0 & 0 & 0 & 1 & 19 & 1 \\
\hline OLE & 0 & 0 & 0 & 0 & 0 & 0 & 3 & 2 & 5 & 0 & 0 & 0 & 0 & 0 & 0 & 14 & 0 & 4 & 0 & 0 & 1 & 0 & 0 & 0 & 39 & 27 & 0 & 0 & 0 & 0 & 5 & 0 \\
\hline $\mathrm{ALI}$ & 0 & 0 & 0 & 0 & 0 & 0 & 5 & 4 & 21 & 0 & 0 & 0 & 0 & 0 & 0 & 0 & 0 & 0 & 0 & 0 & 0 & 1 & 0 & 0 & 0 & 15 & 0 & 0 & 0 & 3 & 47 & 2 \\
\hline DIV & 0 & 0 & 0 & 0 & 0 & 0 & 0 & 0 & 0 & 1 & 4 & 1 & 2 & 5 & 2 & 2 & 0 & 0 & 1 & 0 & 1 & 0 & 0 & 0 & 0 & 1 & 18 & 1 & 37 & 5 & 13 & 5 \\
\hline
\end{tabular}


Tabela 7. Participação do setor j (coluna) no consumo intermediário da produção do setor i (linha).

\begin{tabular}{|c|c|c|c|c|c|c|c|c|c|c|c|c|c|c|c|c|c|c|c|c|c|c|c|c|c|c|c|c|c|c|c|c|}
\hline & $\mathrm{CAF}$ & CAN & ARR & $\mathrm{SOJ}$ & ALG & MIL & $\mathrm{BOV}$ & LEI & $\mathrm{AOU}$ & $\mathrm{EXT}$ & SID & MAQ & MET & AUT & MAD & QUI & ADU & $\mathrm{OQU}$ & TEX & ICAF & BEN & $\mathrm{ABT}$ & LAC & $\mathrm{ACU}$ & OLE & ALI & DIV & SIU & CIV & MAR & SER & $\mathrm{SAD}$ \\
\hline SIU & 0 & 0 & 0 & 0 & 0 & 0 & 0 & 0 & 1 & 1 & 6 & 2 & 1 & 1 & 3 & 5 & 0 & 0 & 2 & 0 & 1 & 1 & 0 & 0 & 0 & 2 & 2 & 32 & 1 & 9 & 13 & 16 \\
\hline CIV & 0 & 0 & 0 & 0 & 0 & 0 & 0 & 0 & 0 & 1 & 1 & 1 & 1 & 1 & 1 & 1 & 0 & 0 & 0 & 0 & 0 & 0 & 0 & 0 & 0 & 0 & 1 & 2 & 39 & 5 & 36 & 11 \\
\hline MAR & 0 & 1 & 0 & 1 & 0 & 0 & 0 & 1 & 1 & 1 & 4 & 2 & 3 & 3 & 4 & 7 & 0 & 1 & 3 & 0 & 3 & 2 & 0 & 1 & 2 & 4 & 3 & 1 & 8 & 20 & 14 & 11 \\
\hline SER & 0 & 0 & 0 & 0 & 0 & 0 & 0 & 0 & 0 & 1 & 1 & 1 & 1 & 1 & 1 & 2 & 0 & 0 & 1 & 0 & 0 & 0 & 0 & 0 & 0 & 1 & 1 & 2 & 2 & 12 & 51 & 20 \\
\hline SAD & 0 & 0 & 0 & 1 & 0 & 0 & 0 & 1 & 2 & 1 & 1 & 1 & 1 & 2 & 10 & 3 & 1 & 0 & 1 & 0 & 2 & 0 & 0 & 0 & 0 & 2 & 2 & 2 & 2 & 13 & 20 & 29 \\
\hline
\end{tabular}


Outros da agropecuária (Tabela 7). No entanto, mesmo a conexão do referido setor com os setores agroindustriais não foi suficiente para promover a elevação do preço para a produção.

Pode-se constatar esse fato a partir da observação da Tabela 8, que apresenta a variação média do preço para a produção, calculada considerando-se os setores agroindustriais de exportação (indústria de café, açúcar e óleos vegetais), os agroindustriais de alimentação (beneficiamento prod. vegetal, abate animais, laticínios e outros prod. alimentares) e agroindustriais da Madeira/papel e têxtil. A variação do grupo agroindústria de alimentação foi a menor observada dentre os grupos agroindustriais, refletindo a sua menor assimilação do impacto gerado pela alteração do preço de exportação.

Tabela 8. Efeito da desvalorização sobre os preços para a produção da agroindústria no todo e em sub-grupos.

\begin{tabular}{lcrc}
\hline Grupo & $\begin{array}{c}\text { Participação } \\
\text { na produção } \\
\text { base* }\end{array}$ & $\begin{array}{c}\text { Preço para a } \\
\text { produção (média) } \\
\text { Base* }\end{array}$ & $\begin{array}{c}\text { Choque* } \\
\text { Agroindústria (todas) }\end{array}$ \\
Agroindústria de exportação & $100 \%$ & 1,0 & 1,015 \\
Agroindústria da alimentação & $44 \%$ & 1,0 & 1,042 \\
Agroindústria madeira/papel e têxtil & $42 \%$ & 1,0 & 1,007 \\
\hline * base - solução base; choque - solução após a desvalorização & 1,0 & 1,014 \\
\hline
\end{tabular}

A importância do efeito negativo sobre o preço para a produção do setor Outros da agropecuária, no resultado geral do grupo agropecuário como um todo, pode ser notada a partir dos dados apresentados na Tabela 9. Enquanto os setores tradables de exportação (café, cana-de-açúcar e soja) receberam estímulo de 6,7\% no preço para a produção, os tradables substitutos de importados (arroz, algodão, milho bovinos e leite) receberam $1,9 \%$ e o setor Outros da agropecuária $-0,4 \%$. No geral, quando se calcula a 
média ponderada entre todos os setores tem-se o valor de $1,3 \%$, refletindo o peso do setor Outros da agropecuária.

Tabela 9. Efeito da desvalorização sobre a alteração de preços para a produção da agropecuária no todo e em sub-grupos.

\begin{tabular}{lccc}
\hline Grupo & $\begin{array}{c}\text { Participação } \\
\text { na produção } \\
\text { Base* }\end{array}$ & $\begin{array}{c}\text { preço para a } \\
\text { produção } \\
\text { Base* }\end{array}$ & Choque* \\
\hline Agropecuária (todos) & $100 \%$ & 1,0 & 1,013 \\
Tradables de exportação & $15 \%$ & 1,0 & 1,067 \\
Tradables substitutos de importados & $30 \%$ & 1,0 & 1,019 \\
Setor Outros da agropecuária & $56 \%$ & 1,0 & 0,996 \\
\hline
\end{tabular}

Com relação a resposta da produção setorial em volume, tem-se o comportamento retratado na Figura 26. Percebe-se que alguns setores apresentaram variação da produção em volume muito pequeno ou negativo em relação aos demais, quais sejam: Bovinos/suínos, Leite natural, Outros da agropecuária, Máquinas e tratores, Abate de animais, Laticínios, Outros produtos alimentares, Serviços de utilidade pública (SIUP), Construção civil, Margens, Serviços e Serviços da administração pública. O comportamento mais inesperado do setor Máquinas/tratores frente à uma desvalorização, pode ser explicado pela forte relação deste setor com setores non-tradables da economia brasileira, Construção Civil, Margens de comércio e transporte, SIUP, Serviços e Administração pública, responsáveis por $25 \%$ do total de consumo intermediário.

A resposta diminuta ou negativa do volume de produção dos citados setores, implica afirmar que a desvalorização da taxa de câmbio não promoveu um estímulo de produção generalizado, pelo contrário, determinados setores foram até prejudicados. Este fato pode ser explicado por uma posição mais voltada para o mercado interno desses setores e pela menor relação com setores de exportação. 


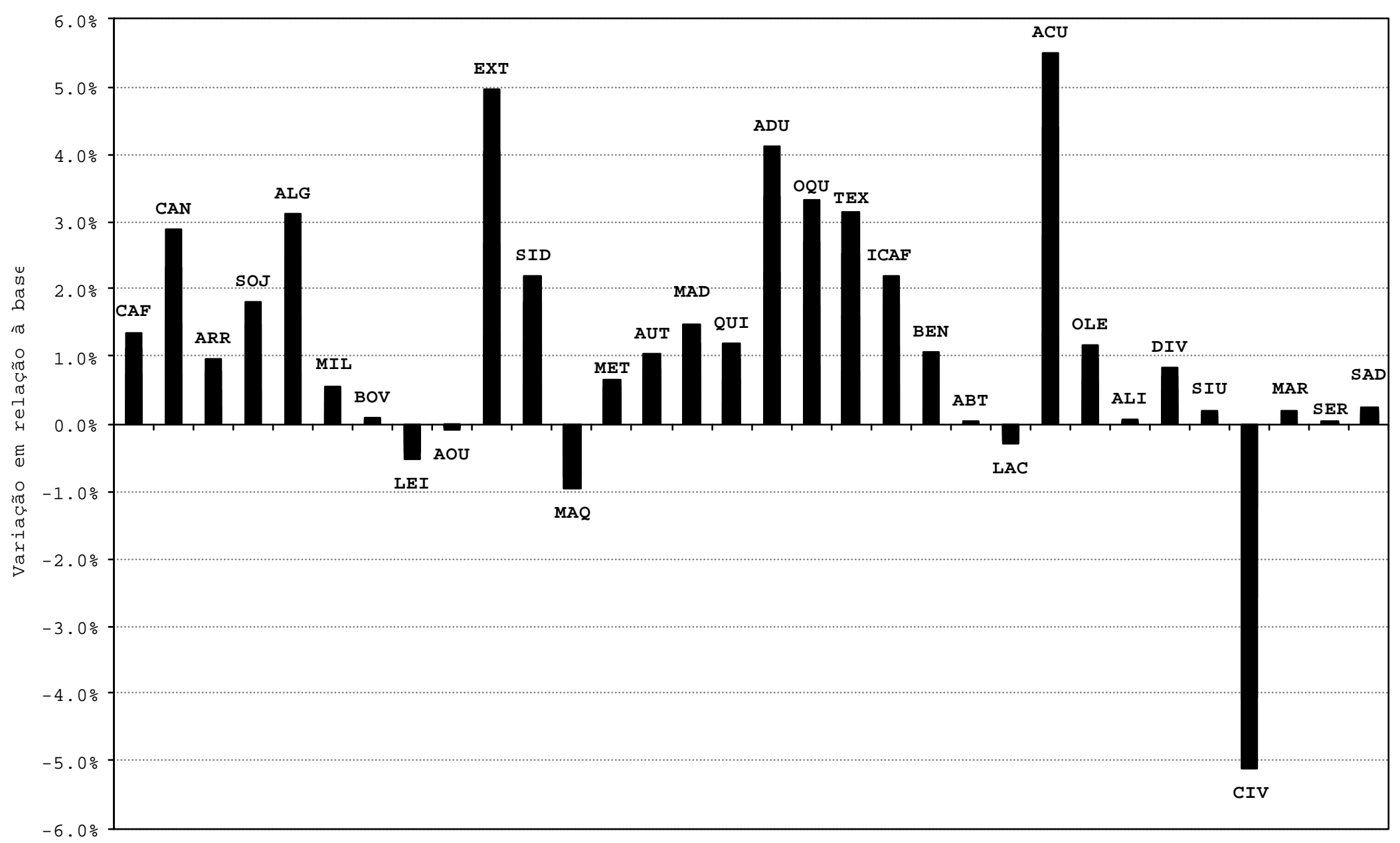

Figura 26 - Impacto sobre a produção em volume da desvalorização da taxa de câmbio. 
Por fim, o impacto sobre o valor da produção é apresentado na Figura 27. O resultado da produção em valor foi um efeito resultante da modificação no preço e no volume, discutidos anteriormente.

A produção foi afetada de forma diferenciada, conforme era de se esperar, sendo os setores mais voltados para o mercado externo favorecidos pelo processo de desvalorização da moeda nacional. Na agropecuária, claramente evidenciou-se o efeito direto, referente aos setores café e soja, que por apresentarem parte mais significativa da produção destinada à exportação, foram diretamente beneficiados pela desvalorização. Ao mesmo tempo, também foi possível constatar que os mesmos setores café, soja, mais o setor Cana-de-açúcar e Algodão foram indiretamente beneficiados pela demanda dos setores agroindustriais Indústria do Café, Fabricação de Óleos vegetais e Indústria do Açúcar; além das indústrias Química e Têxtil. Com benefícios indiretos menores, mas ainda existentes apareceram os setores do arroz, milho e bovinos/suínos, que se relacionaram com o grupo de agroindústrias ligados à alimentação, menos favorecido pelo processo de desvalorização. O setor Leite natural apresentou um resultado negativo, reforçado pela Indústria de Laticínios, prejudicada por apresentar muito baixo coeficiente de exportação e por ter tido o segundo maior coeficiente de importação dentre as agroindústrias (perdendo apenas para a Indústria Têxtil).

Do ponto de vista da média dos setores ligados à agropecuária e dos setores ligados à agroindústria, gerou-se os resultados apresentados na Tabela 10. 
Tabela 10. Efeito da desvalorização sobre a alteração da produção em valor da agropecuária e da agroindústria no todo e em sub-grupos.

\begin{tabular}{lcc}
\hline Grupo & $\begin{array}{c}\text { Participação } \\
\text { na produção } \\
\text { Base* }\end{array}$ & $\begin{array}{c}\text { Variação da } \\
\text { produção em } \\
\text { valor Choque* }\end{array}$ \\
\hline Agropecuária (todos) & $100 \%$ & $1,6 \%$ \\
Agrop. Tradables de exportação & $15 \%$ & $8,8 \%$ \\
Agrop. Tradables substitutos de & $30 \%$ & $2,0 \%$ \\
importados & & $-0,5 \%$ \\
Setor Outros da agropecuária & $56 \%$ & $3,0 \%$ \\
Agroindústria (todas) & $100 \%$ & $6,8 \%$ \\
Agroindústria de exportação & $14 \%$ & $1,0 \%$ \\
Agroindústria da alimentação & $44 \%$ & $3,7 \%$ \\
Agroindústria madeira/papel e têxtil & $42 \%$ & \\
\hline
\end{tabular}

O setor Outros da agropecuária, representando $56 \%$ do valor da produção da agropecuária como um todo, com maior parcela non-tradable, apresentou um resultado negativo, não obstante à contribuição da parcela tradable e do efeito indireto dos setores agroindustriais mais favorecidos como a Indústria dos Óleos vegetais. O que prevaleceu foi o efeito direto negativo, típico dos setores non-tradables, associado a uma baixa contribuição das agroindústrias do citado grupo da alimentação, com apenas $1 \%$ de aumento da produção em valor contra os $6,8 \%$ da agroindústria de exportação (conforme Tabela 10). O benefício da agropecuária com um todo principalmente do grupo de setores agropecuários tradables de exportação foi reduzido quando se considerou a resposta dos setores agropecuários tradables substitutos de importados e o setor Outros da agropecuária. Comportamento semelhante foi observado para a agroindústria, onde o benefício auferido pelo grupo exportador foi reduzido pelos grupos Alimentação e Madeira/papel-textil 
Outro aspecto a ser observado são as alterações na renda do trabalho gerada por cada setor. Como se sabe, a estrutura de modelagem adotada, assume a mobilidade plena da mão-de-obra. Diante de uma mudança nos preços relativos o trabalho será realocado até o ponto em que se atinja o novo equilíbrio. Com base na Figura 28, que apresenta a variação observada na renda setorial após a desvalorização, nota-se que os setores Leite natural, Outros produtos agropecuários, Máquinas/tratores, Abate de animais, Indústria de laticínios, Outros produtos alimentares, SIUP, Construção civil, Margens, Serviços e Administração pública, apresentaram redução na renda por eles gerada. Com exceção do setor de Máquinas/tratores, todos os demais apresentaram um comportamento voltado para o mercado interno, sofrendo assim os impactos como se fossem setores non-tradables da economia. Assim como no mundo real, a resposta a um choque econômico que afete significativamente os preços relativos, implica na realocação de fatores de produção, cujo estoque é limitado e, assim sendo, determinados setores menos favorecidos pelo choque devem ceder fatores para que os demais possam responder.

Verificando a questão da realocação de trabalho entre setores agropecuários e não agropecuários, percebeu-se que o setor agropecuário demandou 2,1\% a mais de trabalho, quando se comparou a solução base com a solução após a desvalorização. $\mathrm{O}$ montante demandado a mais de trabalho veio dos setores não agropecuários e correspondeu a 5,3\% do total de trabalho disponibilizado por esses setores.

\subsection{Impacto da desvalorização do câmbio sobre as relações de troca}

Complementarmente à análise dos impactos da desvalorização da taxa de câmbio sobre as relações externas e sobre a produção interna, a análise das relações de troca é muito importante para a percepção de como os preços relativos e a estrutura de produção foram negativamente ou positivamente afetados.

O preço dos produtos compostos constitui o referencial de preços pagos pelos insumos adquiridos dos outros setores, conforme é apresentado na Figura 29. O setor 
algodão apresentou a maior alta, indicando que os setores demandantes de seus produtos defrontaram-se com uma elevação significativa de custos. O setor da Construção civil apresentou a maior queda de preços, indicando uma redução de custos para os setores demandantes no consumo intermediário (a participação dos setores na demanda intermediária da Construção Civil podem ser vistos na Tabela 7). Outro setor que também apresentou diminuição do preço composto foi o setor da Indústria do Açúcar.

Tendo os preços compostos e a estrutura de consumo intermediário dos setores (Tabela 5), calculou-se, de acordo com a Metodologia, o índice de custo setorial como é apresentado na Figura 30. Na solução base todos os preços compostos são unitários, o que implica no índice de custo setorial igual a unidade para todos os setores. Uma vez ocorrida a desvalorização, houve a modificação diferenciada do preços compostos setoriais, resultando assim em índices de custo diferentes.

A elevação de custos ocorreu para todos os setores, com exceção do setor de serviços; esse comportamento pode ser explicado pela expressiva parcela do consumo intermediário (56\%, conforme a Tabela 5) composta pelo próprio setor de serviços, cujo preço composto caiu (Figura 29). Os setores da Indústria do Café e Óleos vegetais tiveram aumento destacado de seus custos, uma vez que passaram a gastar mais na aquisição dos insumos agropecuários (café e soja), cujos preços compostos aumentaram.

As agroindústrias do Beneficiamento da produção vegetal, do Abate de animais, de Laticínios e dos Outros produtos alimentares, apresentaram menor aumento de custos em relação aos setores já analisados, por adquirirem insumos agropecuários de setores que tiveram redução ou pequeno aumento do preço composto. Aumento acentuado de custo também foi observado para os setores Café e Soja, pelo fato apresentarem uma parcela do consumo intermediário advinda do próprio setor, como pode ser observado na Tabela 5. O consumo do próprio setor está associado com a aquisição principalmente de sementes e mudas; para o caso do café, o elevado valor pode ser explicado pela transformação de café em coco em café em grão, operação realizada por cooperativas e grupos de produtores não ligados à Indústria do Café. 


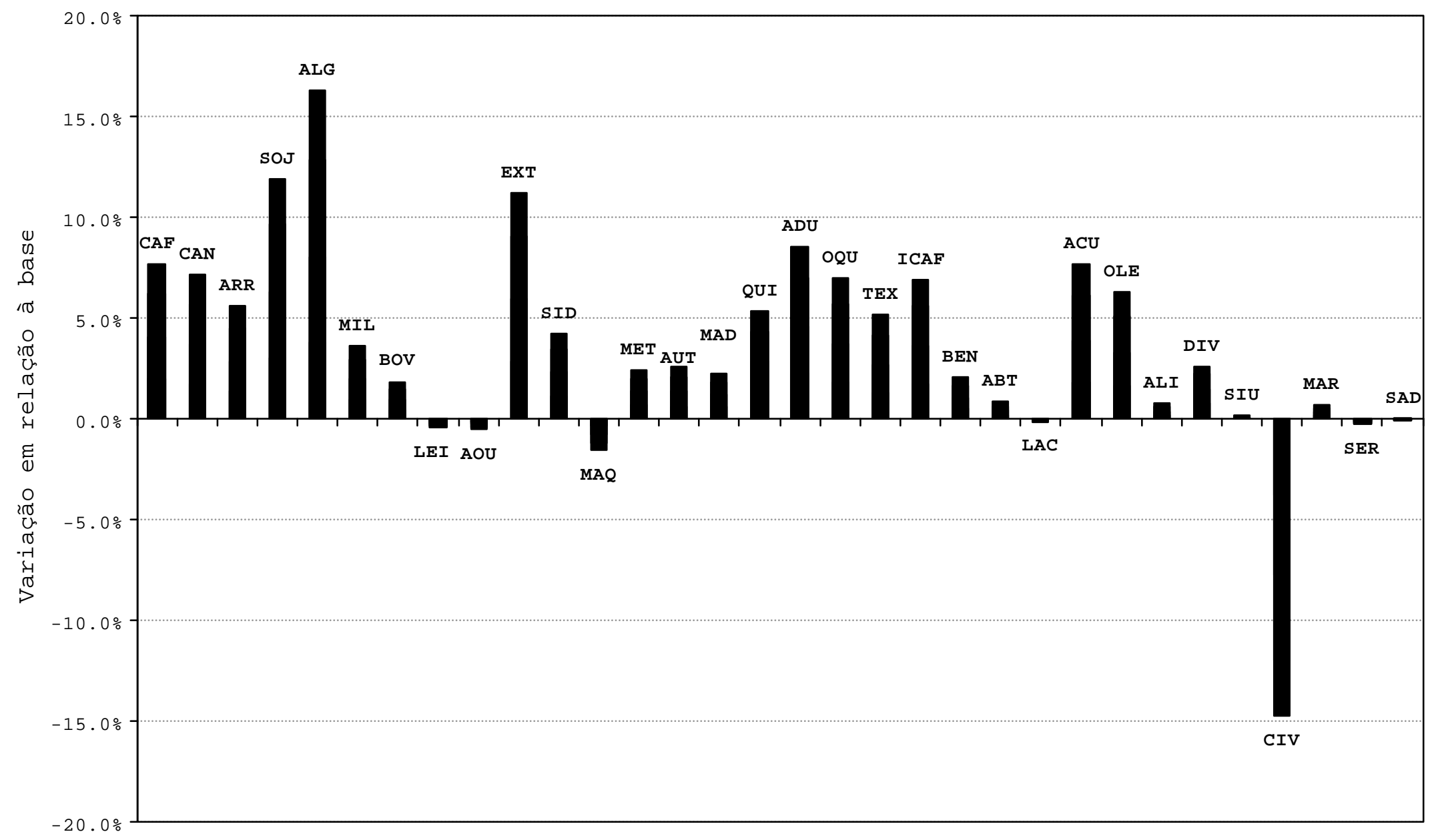

Figura 27 - Impacto sobre a produção em valor da desvalorização da taxa de câmbio. 


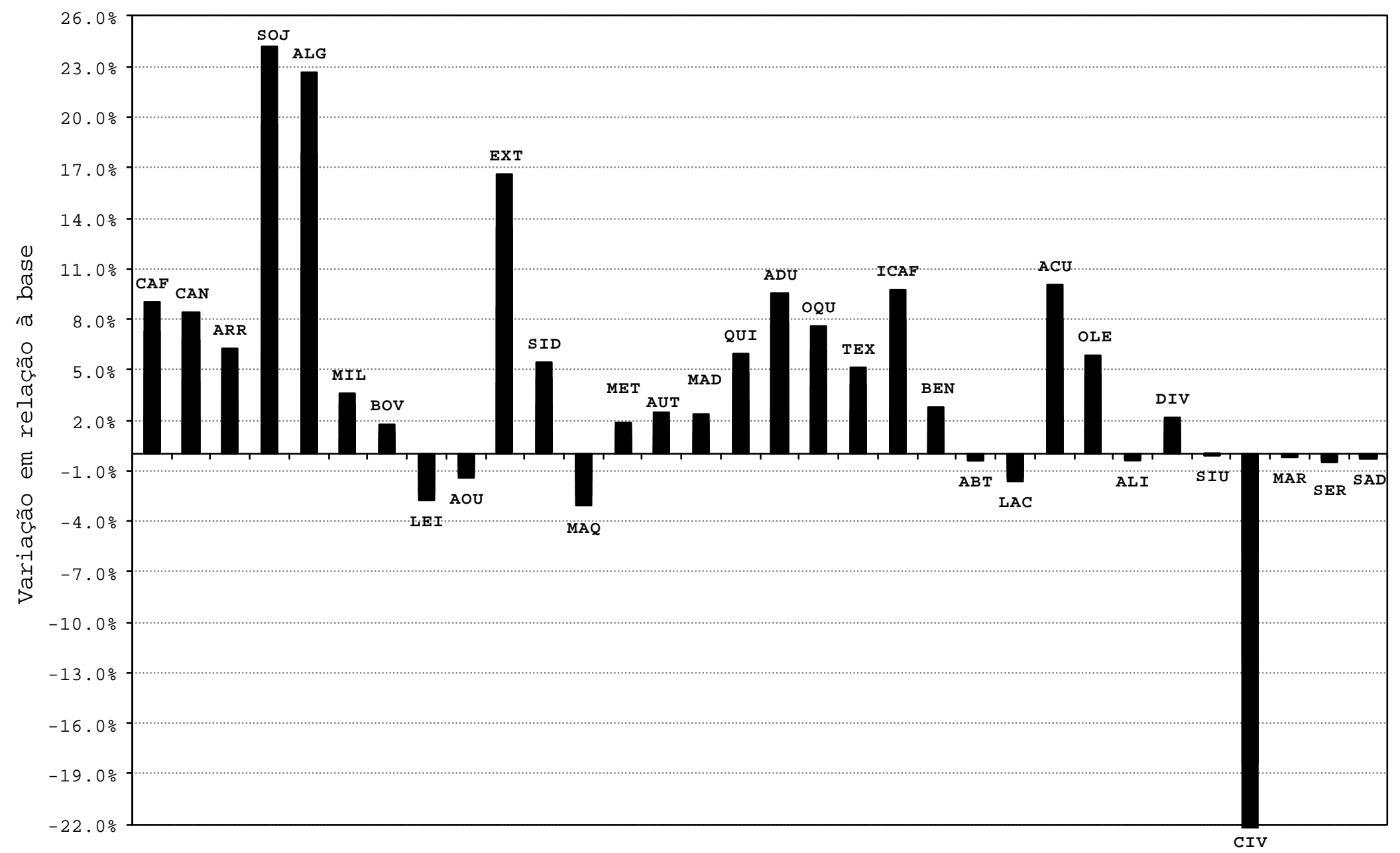

Figura 28 - Impacto da desvalorização sobre a renda do trabalho setorial. 
Quanto ao setor Outros da agropecuária também há um valor significativo de consumo intermediário oriundo do próprio setor, neste caso o índice de custo foi beneficiado pela já apresentada redução do preço composto desse setor.

De forma a explicitar as relações de consumo intermediário do setor com os demais setores fornecedores, desconsiderando as compras dele próprio, elaborou-se o índice de custo extra setor, apresentado na Figura 31, calculado com base na ponderação a partir dos dados da Tabela 6. Os setores agropecuários apresentaram uma menor diferença relativa em comparação com o índice apresentado na Figura 30, indicando que os setores, independente de serem tradables ou non-tradables, são afetados de forma parecida. Este fato é importante de ser notado, pois a desvalorização ao elevar os preços compostos dos setores Adubos, Químicos e Outros químicos, prejudica em custos todos os setores da agropecuária. Uma outra forma eficiente de se verificar os ganhos e perdas de cada setor é através do índice IPR/IPP (preços recebidos em relação aos preços pagos ou termos de troca), apresentado na Figura 32. Confirma-se o efeito negativo da desvalorização para os setores da agropecuária mais voltados para o atendimento de demandas domésticas: Milho, Bovinos/suínos, Leite natural e Outros da agropecuária. Os setores Café, Cana-de-açúcar e Arroz, apresentaram ganhos nos termos de troca com os seus fornecedores e os setores Soja e Algodão foram os grandes beneficiados. Ao se observar o IPR/IPP calculado considerando-se o índice de custo extra setor, observa-se a ocorrência de pequenas modificações (Figura 33). Os setores agropecuários tenderam a apresentar um aumento no IPR/IPP. Para o caso dos setores industriais e agroindustriais observou-se ao contrário, uma redução do IPR/IPP. Analisando-se o IPR/IPP calculado para os grupos de setores agropecuários e agroindustriais, Tabela 11, nota-se que os setores agropecuários tradables de exportação realmente ganham em termos de troca. Os tradables substitutos de importados praticamente mantiveram os termos de troca no patamar inicial. Já o setor Outros da agropecuária, que incorpora o setores non-tradables, apresentou uma perda de $1,7 \%$ nos seus termos de troca. 


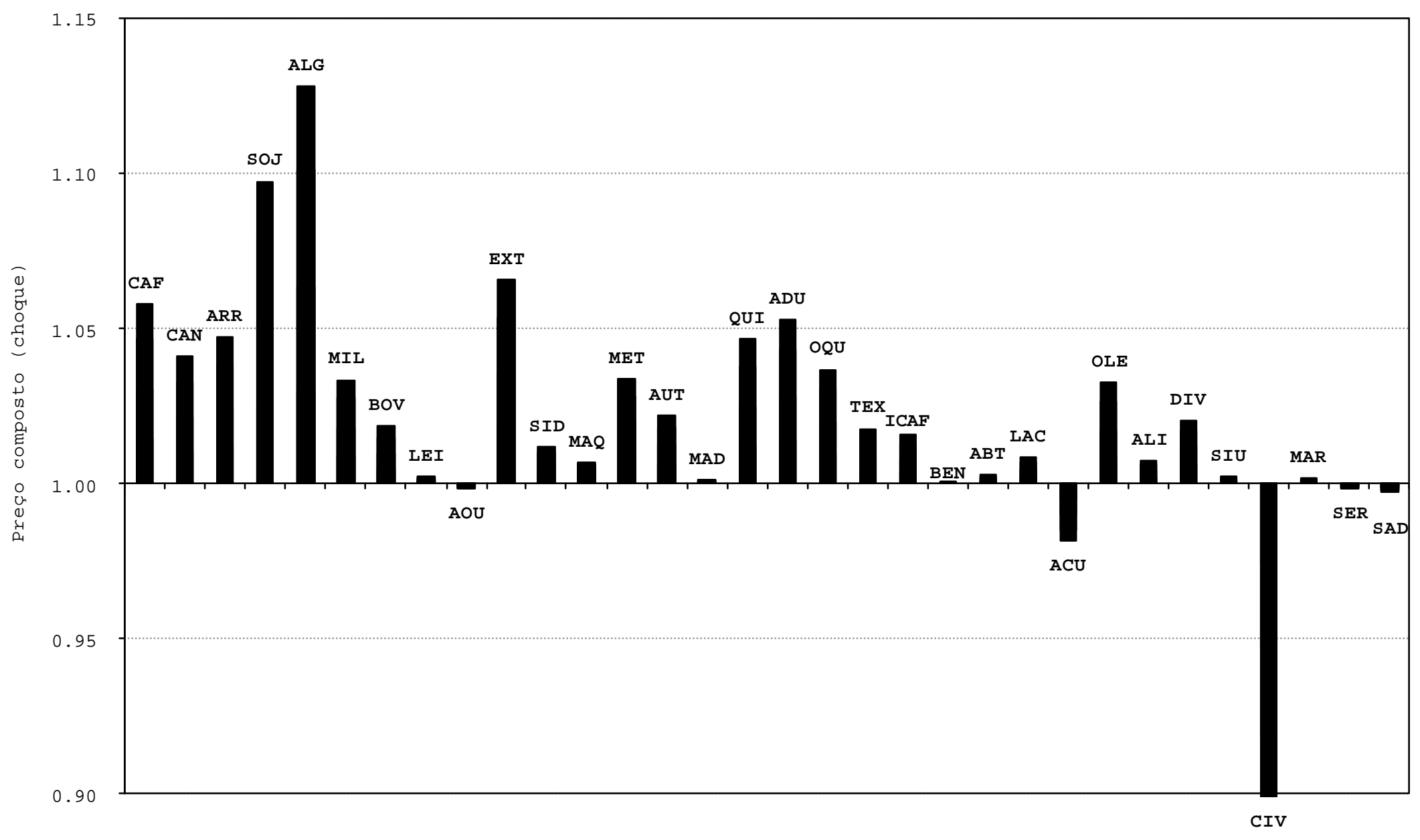

Figura 29 - Impacto da desvalorização da taxa de câmbio sobre o preço composto. 


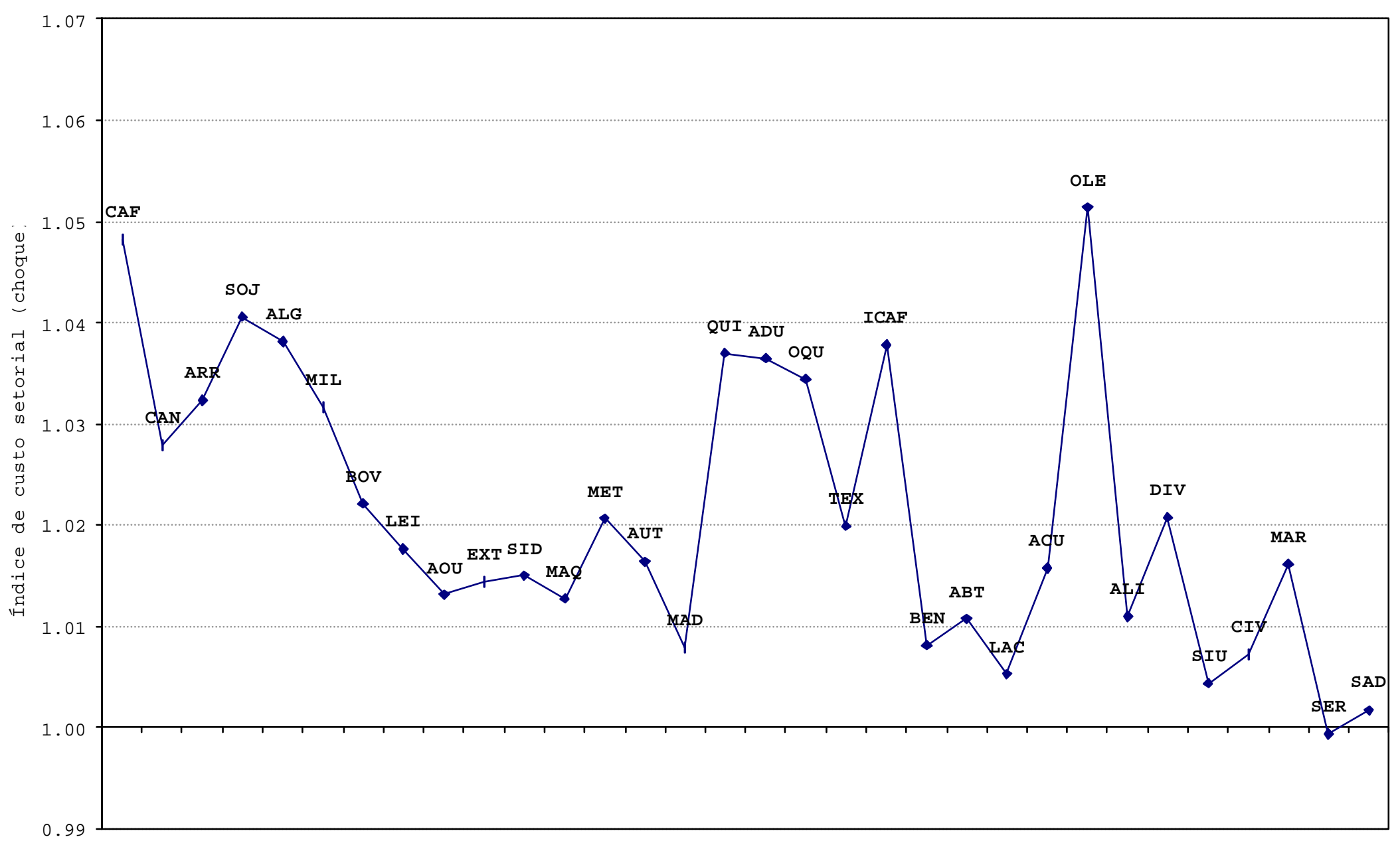

Figura 30 - Índice de custo setorial calculado a partir do impacto da desvalorização sobre o preço composto. 


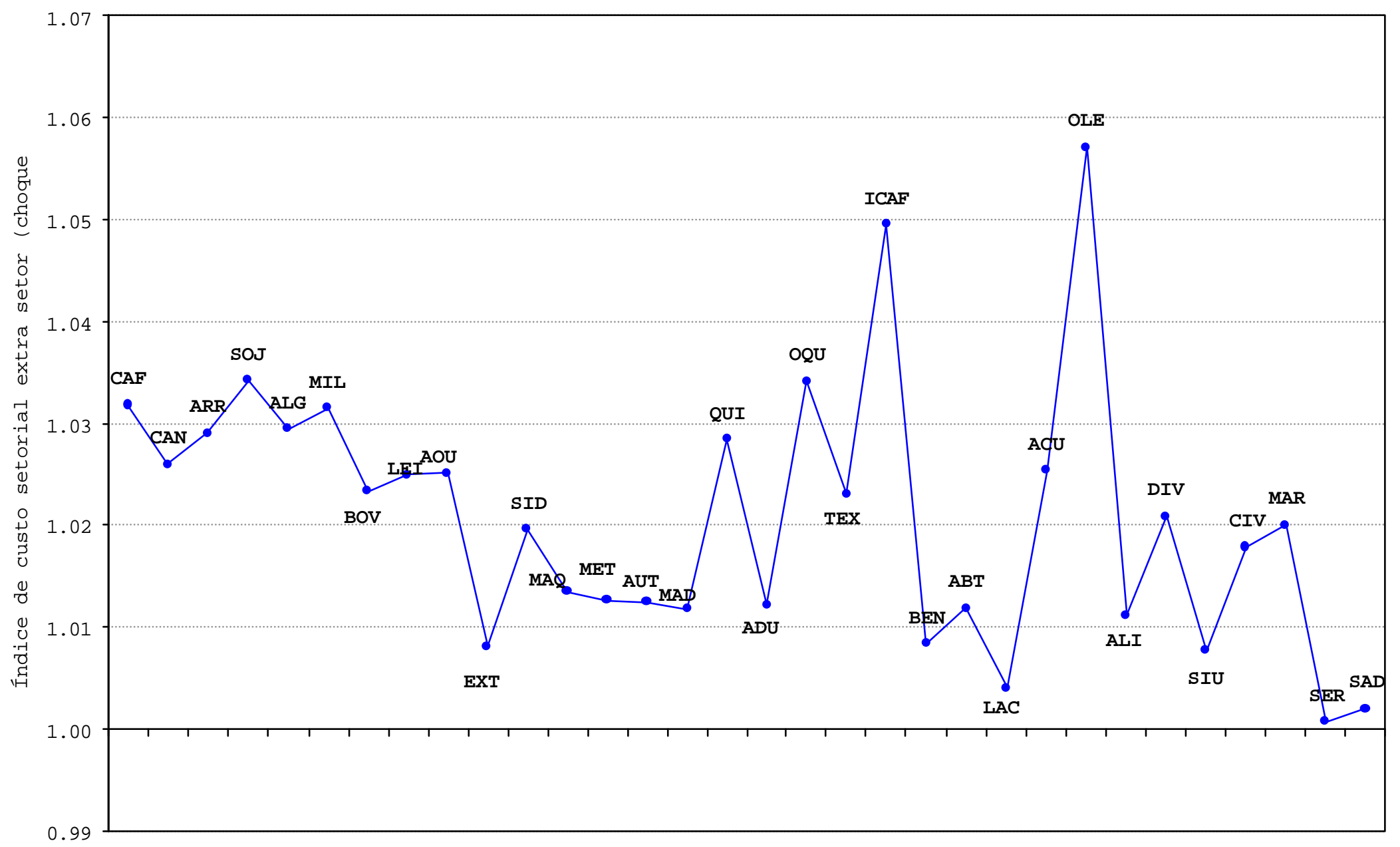

Figura 31 - Índice de custo setorial extra setor, calculado a partir do impacto da desvalorização sobre o preço composto. 


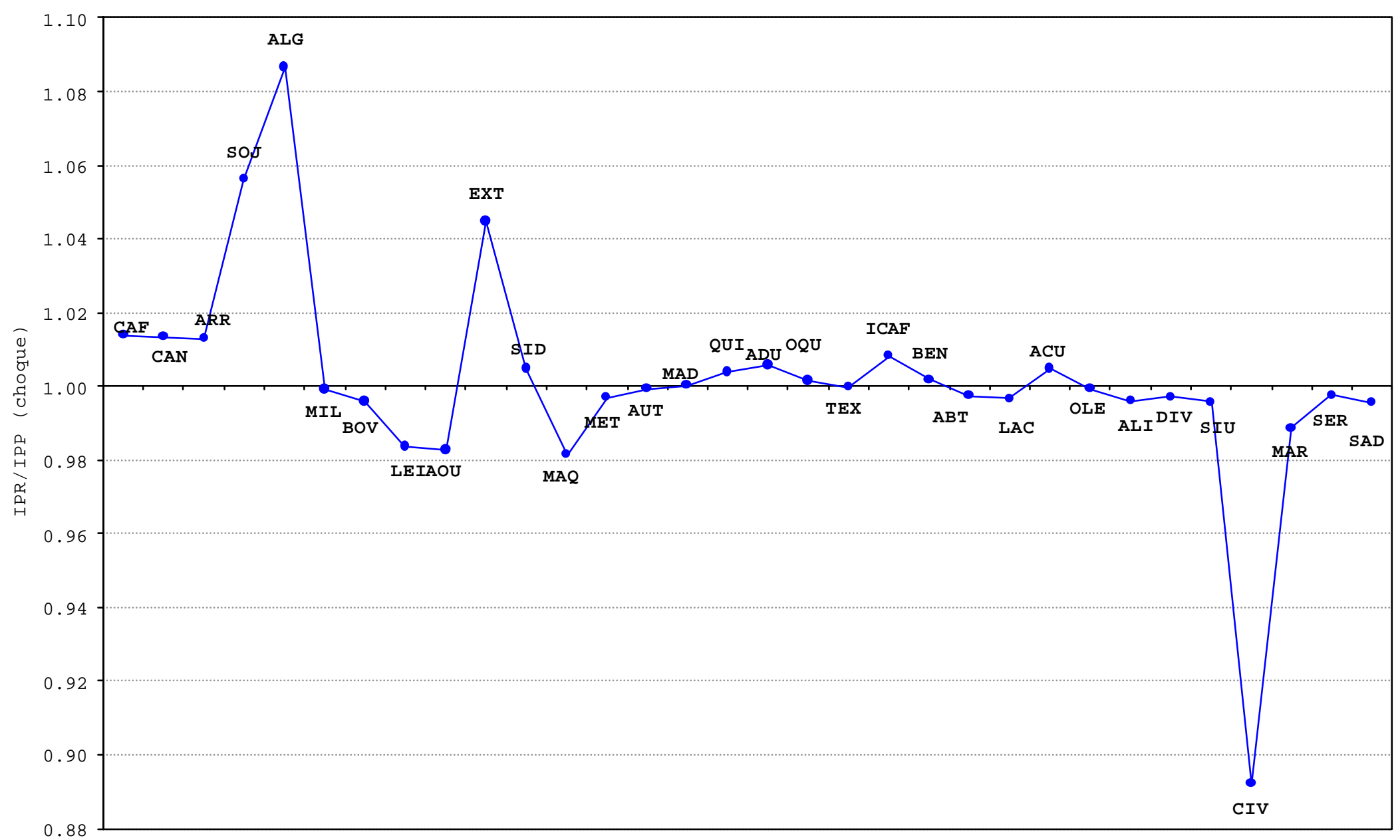

Figura 32 - Índice IPR/IPP, calculado a partir do impacto da desvalorização sobre o índice de custo e o preço para a produção. 


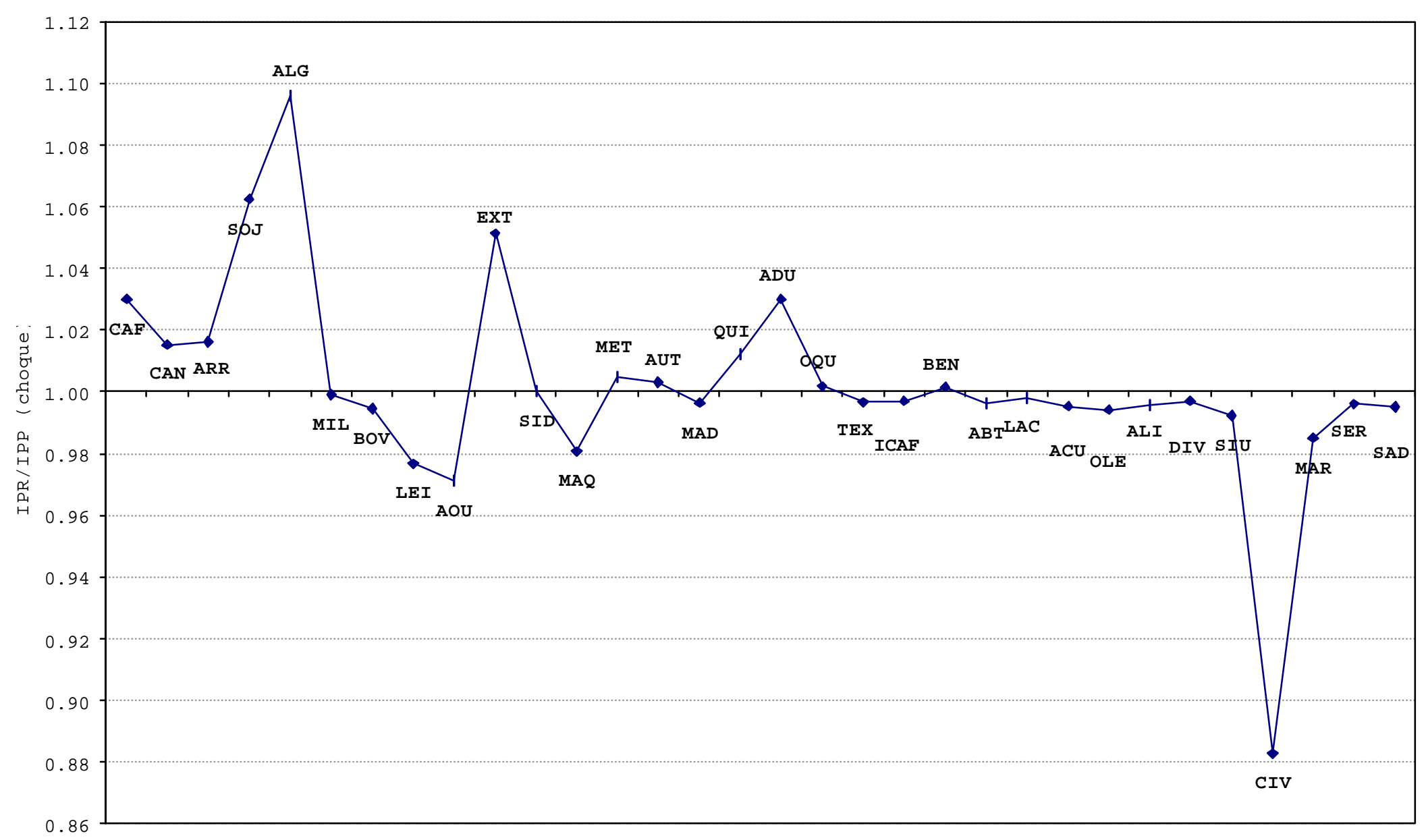

Figura 33 - Índice IPR/IPP, calculado a partir do impacto da desvalorização sobre o índice de custo extra setor e o preço para a produção. 
Tabela 11. Efeito da desvalorização sobre a alteração do IPR/IPP da agropecuária e da agroindústria no geral e em sub-grupos.

\begin{tabular}{lcccc}
\hline Grupo & IPR/IPP & $\begin{array}{c}\text { IPR/IPP } \\
\text { (extra setor) } \\
\end{array}$ & Base* & Choque* \\
Base* & Choque* \\
\hline Agropecuária (geral) & 1,0 & 0,992 & 1,0 & 0,987 \\
Tradables de exportação & 1,0 & 1,027 & 1,0 & 1,035 \\
Tradables substitutos de importados & 1,0 & 0,997 & 1,0 & 0,993 \\
Setor Outros da agropecuária & 1,0 & 0,983 & 1,0 & 0,971 \\
Agroindústria (geral) & 1,0 & 0,999 & 1,0 & 0,996 \\
Agroindústria de exportação & 1,0 & 1,003 & 1,0 & 0,995 \\
Agroindústria da alimentação & 1,0 & 0,998 & 1,0 & 0,998 \\
Agroindústria madeira/papel e têxtil & 1,0 & 1,000 & 1,0 & 0,996 \\
\hline * base - solução base; choque - solução após a desvalorização &
\end{tabular}

Do ponto de vista geral da agropecuária o IPR/IPP praticamente não se alterou, reforçando a ausência de ganhos face à desvalorização da taxa de câmbio. Resultado este também apresentado pelos setores agroindustriais como um todo.

Quando se analisa o IPR/IPP calculado considerando o índice de custos extra setorial, percebe-se que os efeitos se acentuam. No sentido positivo como é o caso do grupo Tradables de exportação que ganha 3,5\% nos termos de troca. Já o setor outros da agropecuária apresentou a perda de $-2,9 \%$ nos termos de troca. No fim os ganhos foram superados pelas perdas, resultando em -1,3\% nos termos de troca da agropecuária em geral. Para a agroindústria, praticamente não há alteração, o que indica que a desvalorização não favoreceu no sentido da melhoria dos termos de troca. 


\subsubsection{Termos de troca dos setores agropecuários em relação aos principais setores fornecedores de produtos para o consumo intermediário}

Objetivando aprofundar ainda mais a investigação sobre os efeitos da desvalorização do câmbio sobre os termos de troca, calculou-se o IPR/IPP correspondente à relação do preço recebido pelo setor pertencente ao grupo agropecuário versus o preço pago para cada um dos principais setores fornecedores do consumo intermediário. Os resultados são apresentados nas Figuras 34 a 37, sendo os pontos das curvas referentes aos valores resultantes das desvalorizações da taxa de câmbio nominal.

Analisando os índices calculados para o setor Café, apresentados no primeiro gráfico da Figura 34, nota-se que ocorreu melhoria dos termos de troca em relação aos principais setores fornecedores de produtos do consumo intermediário. Comparativamente, no entanto, o ganho foi menor para os termos de troca com os setores Químicos, Adubos e Outros químicos, que representavam um total de $61 \%$ do consumo intermediário extra setor (Tabela 6). Os maiores ganhos aconteceram frente aos setores de serviços ${ }^{9}$, caracterizando o benefício obtido por setores tradables frente aos non-tradables.

O setor Cana-de-açúcar, tratado na mesma Figura 34, apresentou perda em sua relação de troca com os setores Químicos e Adubos, que representavam $42 \%$ do consumo intermediário extra setor. Ocorreu, por outro lado, a compensação do efeito negativo pelos setores de Serviços, Máquinas/tratores e Outros químicos, cujos preços perderam em termos relativos aos preços para a produção da cana-de-açúcar. Destaca-se neste sentido, o ganho relativo ao setor de Margens de comércio e transporte, um ítem de extrema importância no consumo intermediário extra setor da cana-de-açúcar (27\% dados da Tabela 6).

O formato da curva, observado para determinados termos de troca, também foi observado por Bautista et al. (1998), e indica o efeito das equações não lineares adotadas no modelo.

\footnotetext{
${ }^{9}$ Fazem parte do chamado setor de serviços os seguintes setores: S.I.U.P (serviços de utilidade pública), Margens de comércio e transporte, Serviços e Administração pública.
} 
Comportamento semelhante ao observado para o setor Cana-de-açúcar ocorreu para o setor Arroz, que perdeu em termos relativos para os setores Químicos e Adubos, importantes setores por representarem $44 \%$ do consumo intermediário extra setor (Figura 35). Os ganhos relativos obtidos sobre os outros setores, permitiram a melhoria geral do termos de troca do setor Arroz, como foi observado anteriormente na Figura 33.

Os setores Soja e Algodão apresentaram ganho em seus termos de troca com relação a todos os setores fornecedores de produtos para consumo intermediário, como pode ser notado nas Figuras 35 e 36. Esses dois setores foram de grande destaque em relação aos demais setores agropecuários, realmente beneficiados pelo processo de desvalorização da taxa de câmbio, ambos impulsionados pela demanda intermediária dos setores agroindustriais de Óleos vegetais e Têxtil. Setores agroindustriais que possuem um comportamento voltado para o setor externo, o setor Têxtil com um valor exportado relativamente grande e o setor de Óleos vegetais com semelhante valor e elevada participação das exportações em relação à produção (como foi salientado na discussão realizada a partir das Figuras 21 e 22).

O setor Milho apresentou uma perda dos termos de troca em relação aos setores industriais Químicos, Adubos e Outros químicos, conforme Figura 36. O comportamento geral do IPR/IPP do setor Milho, que apresentou pequena redução com a desvalorização (Figura 32), pode ser melhor explicado com o resultado da relação com cada setor. A perda em termos de troca observada para os principais setores de insumos (Químicos, Adubos e Outros químicos), que representavam 63\% dos gastos com consumo intermediário extra setor, foi compensada pelos ganhos em relação aos setores de serviços e máquinas, amenizando assim a perda em termos de troca. Percebe-se através da análise dos termos de troca que o setor Milho não foi beneficiado pela desvalorização da taxa de câmbio, este resultado pode ser explicado em primeiro lugar pela produção voltada para o mercado interno; e em segundo lugar pela relação com setores agroindustriais voltados para o mercado interno. É elucidativo lembrar que o setor Milho se relaciona no consumo intermediário com setores da própria agropecuária, Bovinos/suínos e Outros da agropecuária, que demandam respectivamente 20\% e 38\% do total ofertado para consumo intermediário (Tabela 7). Com os setores agroindustriais 
o setor Milho relaciona-se com o Beneficiamento de produtos vegetais e Outros produtos alimentares, que juntos demandaram $40 \%$ da produção destinada ao consumo intermediário (Tabela 7).

Antes de se discutir o comportamento dos setores Bovinos/suínos e Leite natural, pode-se observar o comportamento dos termos de troca do setor Outros da agropecuária, apresentado na Figura 38. A perda ocorrida concentrou-se em relação aos setores fornecedores de insumos, como já foi observado em setores agropecuários já analisados. Ocorreu perda em relação ao setor Adubos de 5,4\%, seguida pela perda de 4,9\% em relação aos Químicos e 4\% em relação aos Outros químicos. Esses setores industriais são importantes influenciadores do custo do setor Outros da agropecuária com $34 \%$ do total do consumo intermediário extra setor (Tabela 6). Diferentemente dos demais setores agropecuários já analisados, o setor Outros da agropecuária não apresentou ganho em relação aos setores de serviços, ou seja, o efeito característico de setores nontradables foi mais acentuado, em comparação ao ocorrido para os setores de serviços. A relação com setores agroindustriais como a Madeira/papel, Beneficiamento de produtos vegetais, Abate de animais, Óleos vegetais e Outros produtos alimentares, não foi suficiente para promover um efeito indireto positivo que compensasse as perdas advindas da desvalorização da taxa de câmbio. Em consequiência, no contexto geral, já analisado a partir da Figura 33, a perda em termos de troca foi de aproximadamente 3\%.

Salienta-se a importância do setor Outros da agropecuária no contexto geral da agropecuária brasileira, uma vez que, representa, na solução base, 56\% da produção em valor. Os resultados observados evidenciam que esse setor se comporta como um típico setor non-tradable da economia, que perde com o processo de desvalorização em função da alteração dos preços relativos em favor dos setores mais tradables.

Analisando os setores relacionados com a produção animal, quais sejam Bovinos/suínos e Leite natural, considerando a relação de consumo intermediário com os seus principais setores, diferentes dos tratados anteriormente em função das características do consumo intermediário, de acordo com a Figura 37. Bovinos/suínos ganham apenas em relação ao setor Outros produtos alimentares e ao setor Margens, que constituem $36 \%$ do consumo intermediário extra setor (Tabela 6). No entanto o referido 
ganho foi suplantado pelas perdas ocorridas em relação aos demais setores fornecedores de produtos, em especial para o caso do setor Milho, que representa $46 \%$ do consumo intermediário extra setor (Tabela 6).

Com relação ao setor Leite natural, conforme o gráfico apresentado na Figura 37, não ocorreu ganho relativo aos setores fornecedores de produtos para consumo intermediário. Os valores foram mais acentuados com relação aos setores Químicos e Outros químicos, responsáveis por 39\% do consumo intermediário extra setor. O efeito menos acentuado foi observado com relação aos setores Outros produtos alimentares e Margens, que representam 28\% do consumo intermediário extra setor, o que contribui para amenizar a perda total observada anteriormente para o IPR/IPP geral na Figura 33. Os setores Bovinos/suínos e Leite natural apresentaram um comportamento similar ao observado para o setor Outros da agropecuária, evidenciando a parcela da agropecuária prejudicada pelo processo de desvalorização da taxa de câmbio.

Em linhas gerais a desvalorização valorizou os produtos utilizados como insumos pela agropecuária, em especial os dos setores Químicos, Adubos e Outros químicos. Os setores agropecuários que não se beneficiaram pela desvalorização perderam em termos de troca, em função de serem mais voltados para o mercado interno e de não se relacionarem com setores agroindustriais voltados para o mercado externo. 

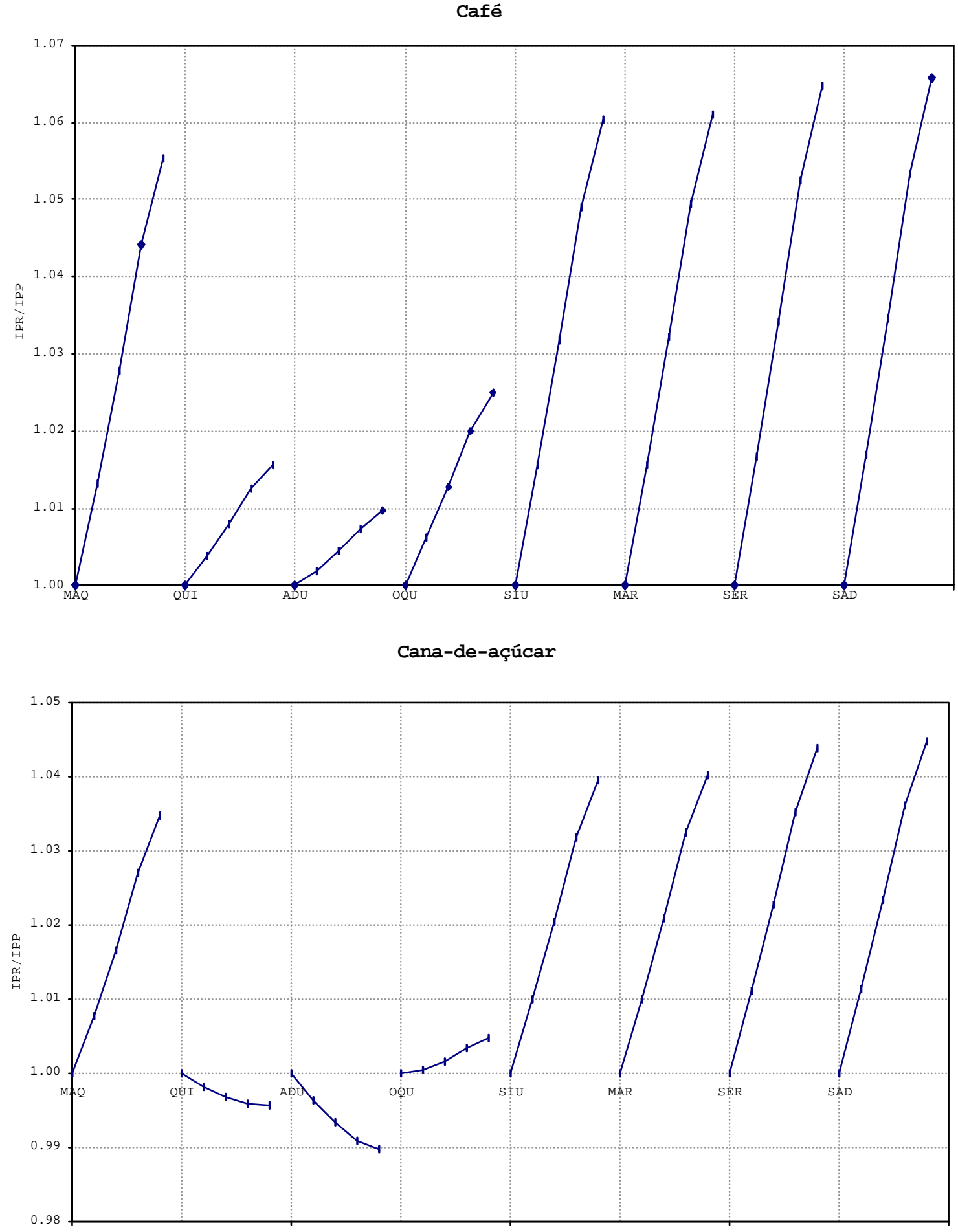

Figura 34 - Variação da relação preço recebido/preço pago em função da desvalorização (setores Café e Cana-de-açúcar). 

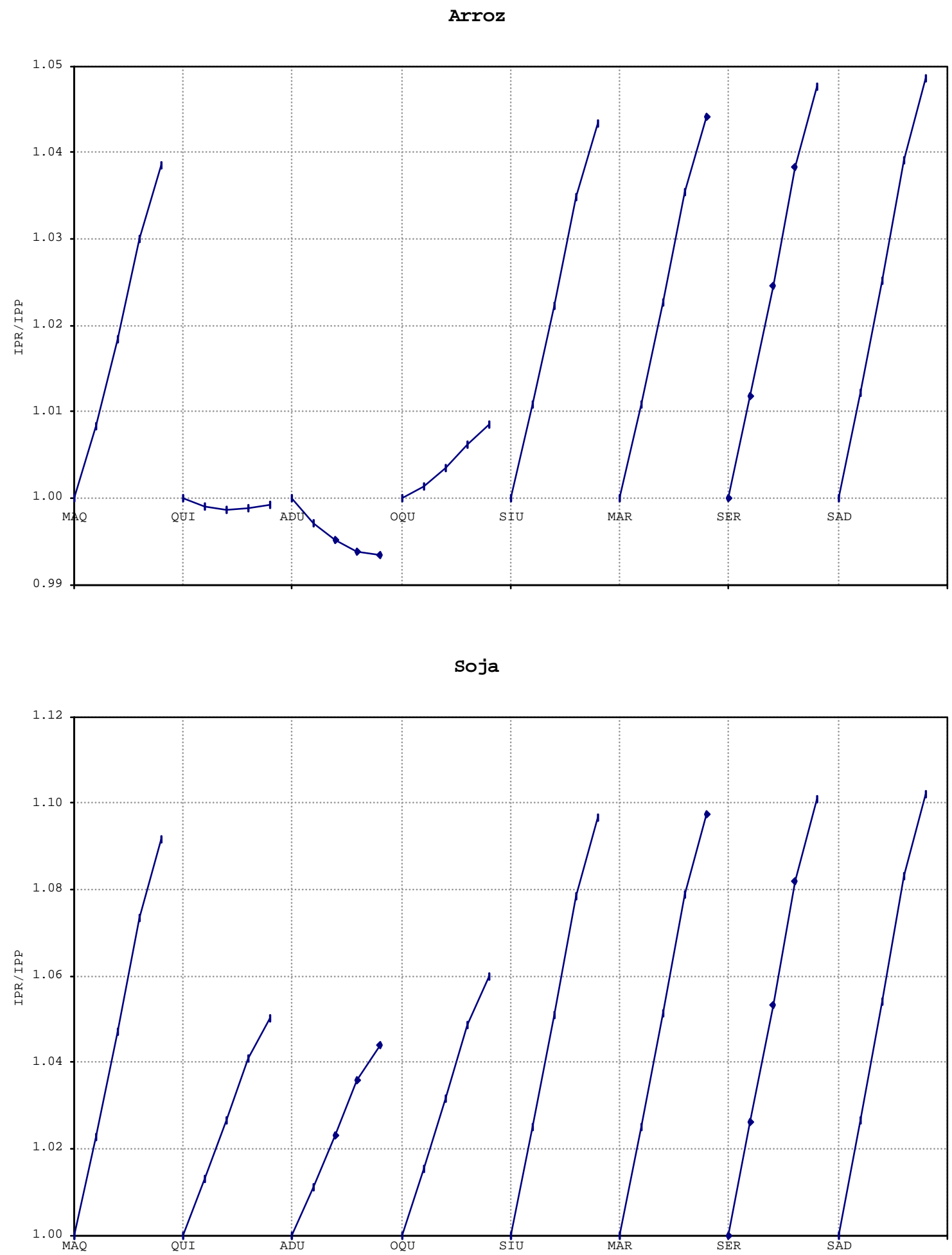

Figura 35 - Variação da relação preço recebido/preço pago em função da desvalorização (setores Arroz e Soja). 

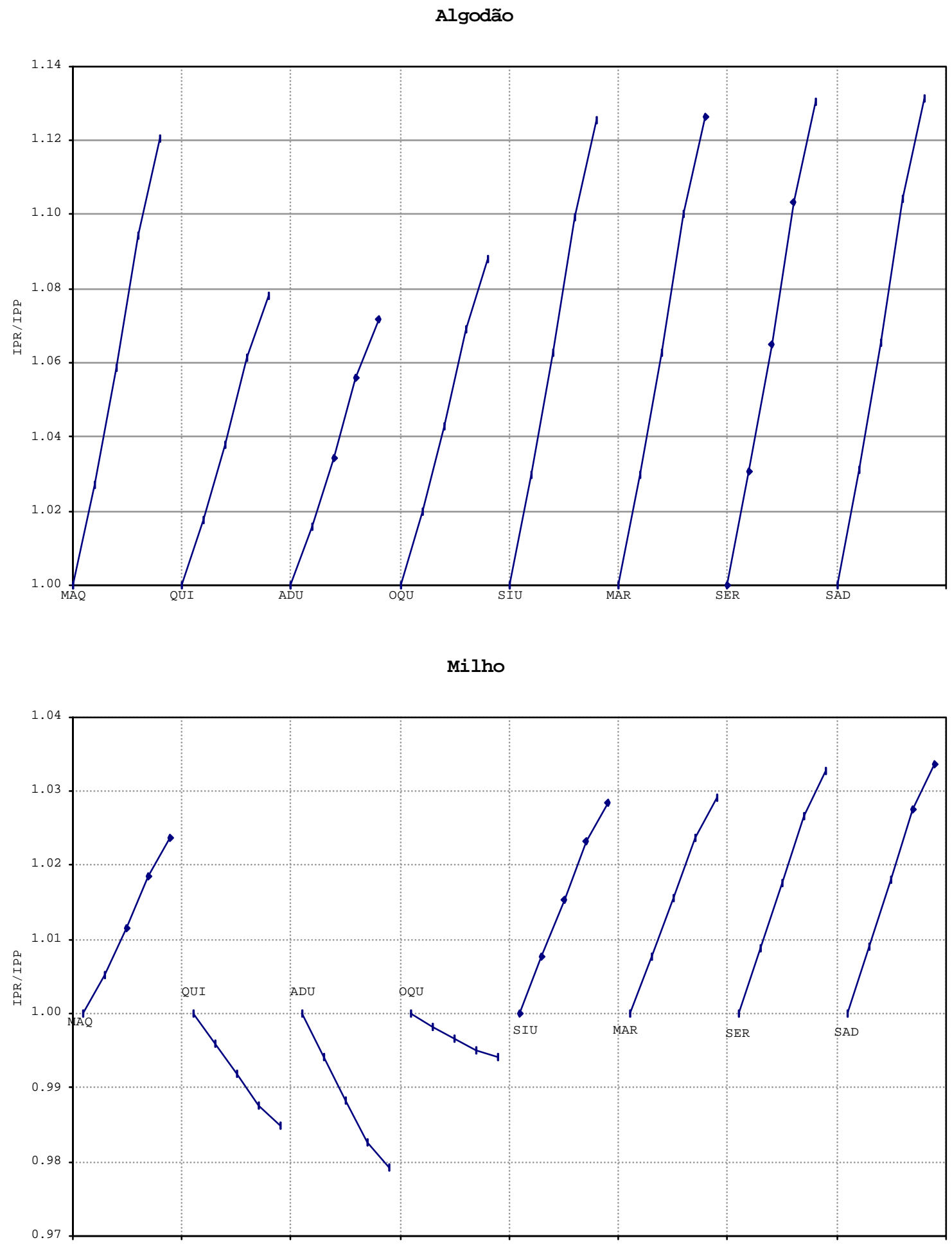

Figura 36 - Variação da relação preço recebido/preço pago em função da desvalorização (setores Algodão e Milho). 

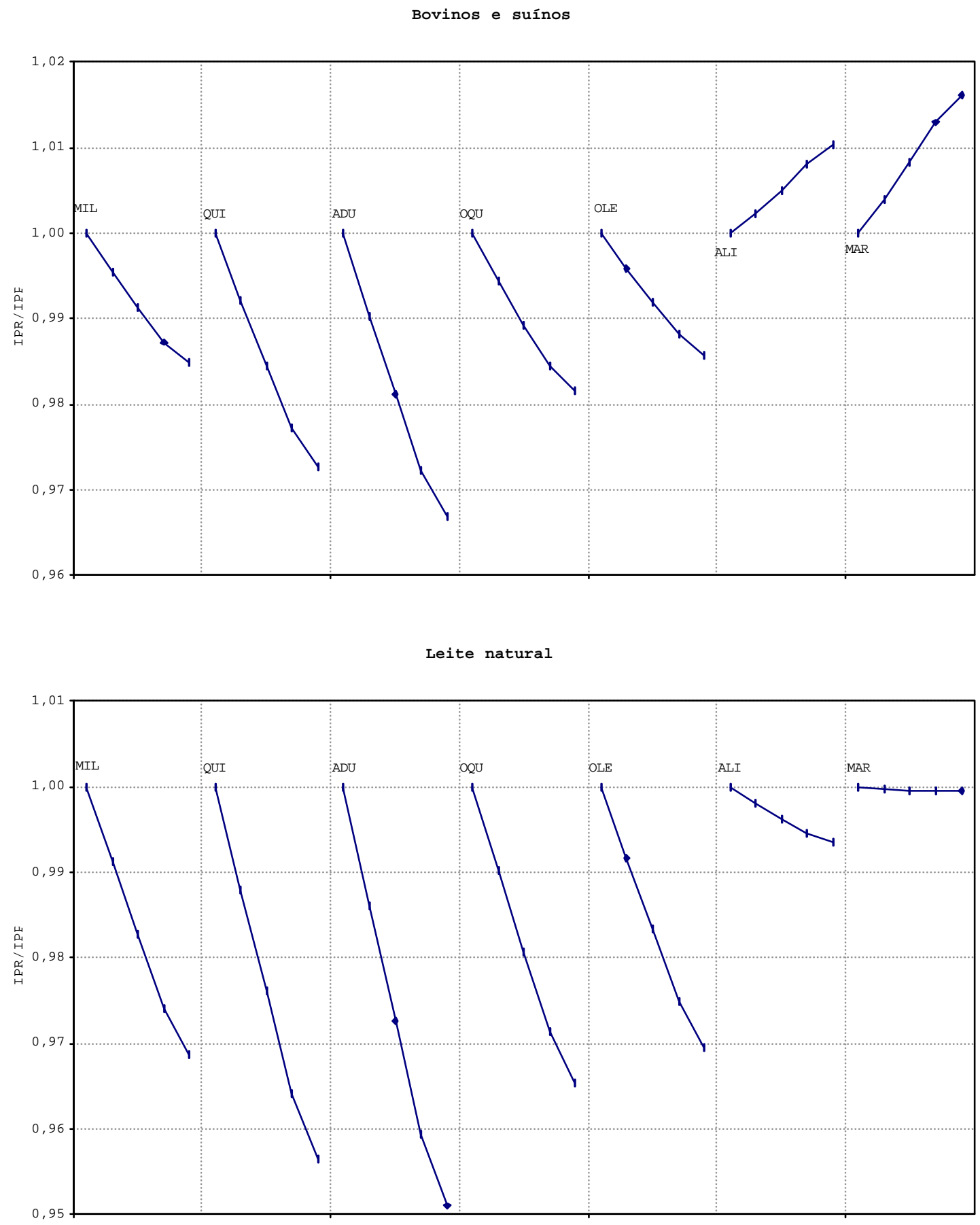

Figura 37 - Variação da relação preço recebido/preço pago em função da desvalorização (setores Bovinos/suínos e Leite natural). 


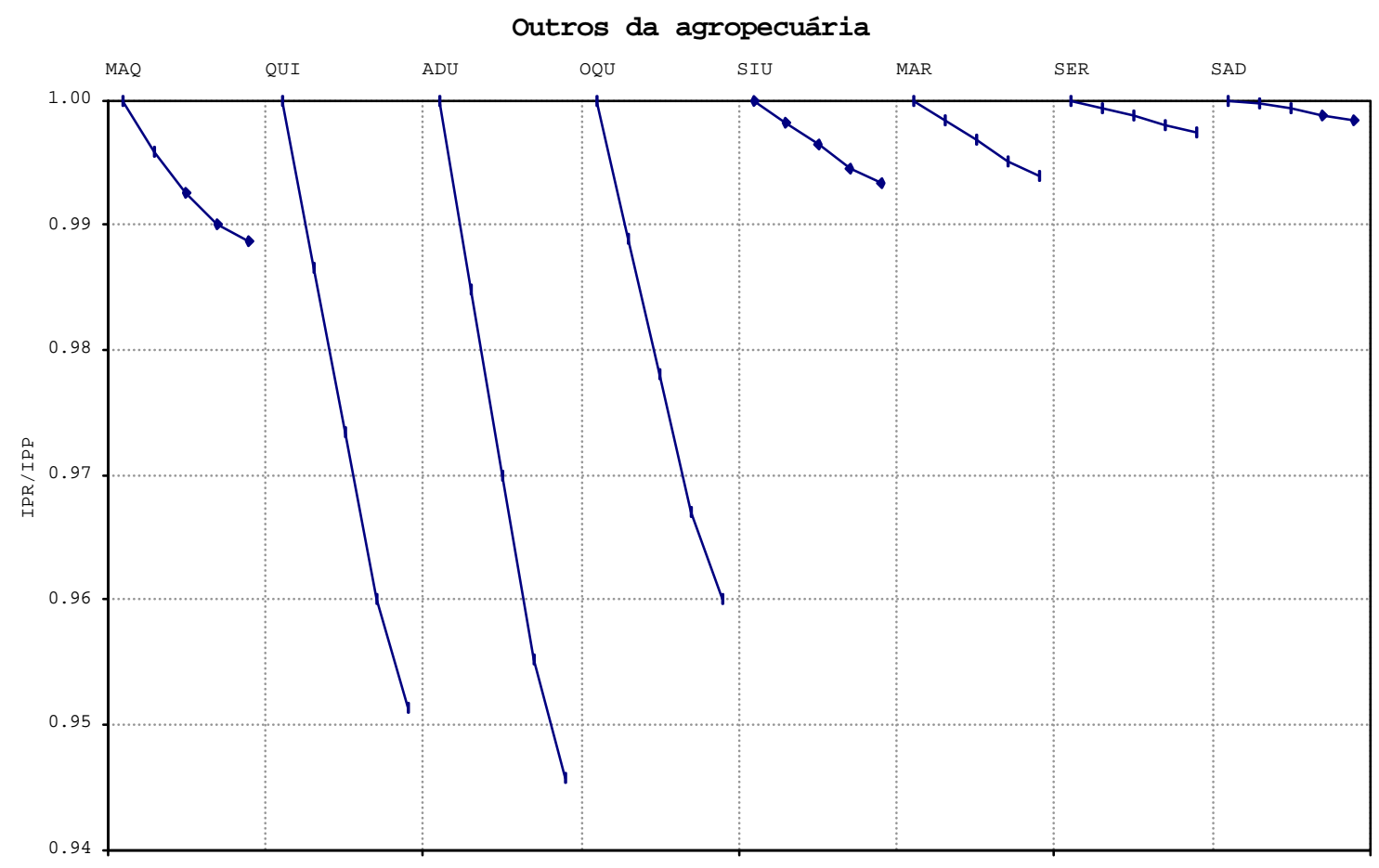

Figura 38 - Variação da relação preço recebido/preço pago em função da desvalorização (setor Outros da agropecuária).

\subsubsection{Termos de troca dos setores agroindustriais em relação aos principais setores fornecedores de produtos para o consumo intermediário}

Analisando o impacto da desvalorização sobre os termos de troca dos setores agroindustriais em relação aos seus principais setores fornecedores de produtos para consumo intermediário, têm-se os gráficos apresentados nas Figuras 39 a 43.

Conforme o que foi observado anteriormente, a partir da análise das Figuras $32 \mathrm{e}$ 33, o setor agroindustrial da Madeira e papel apresentou pequena alteração dos seus termos de troca frente ao choque da desvalorização. Ocorreu, no entanto, uma tendência à redução do valor IPR/IPP, quando se calculou o consumo intermediário extra setor, efeito esse que pode ser analisado a partir dos termos de troca com cada setor do consumo intermediário (Figura 39). Nota-se que ocorreu ganho em relação aos setores Outros da agropecuária e Margens, que representam 37\% do consumo intermediário extra setor. Por outro lado, ocorreu perda de 3,5\% em relação ao setor Químicos, o qual 
representa $20 \%$ do consumo intermediário extra setor (Tabela 6). Percebe-se que na relação da agroindústria com a agropecuária, ocorreu melhoria em favor da primeira, o que pode ser explicado pelo posicionamento mais voltado ao mercado externo do setor Madeira e papel. Não obstante ao ganho em relação ao fornecedor agropecuário, como foi observado o setor Madeira e papel perdeu em relação ao setor Químicos, que apresentou elevação do seu preço composto, dado o montante de importação desse setor (rever Figuras 23, 24 e 29).

Comportamento semelhante à agroindústria da Madeira e papel foi observado para a Indústria Têxtil. Do ponto de vista geral a Indústria Têxtil apresentou pequena alteração dos seus termos de troca, como pode ser observado nas Figuras 32 e 33. A relação com cada setor do consumo intermediário, é apresentada na Figura 39. Em relação aos setores Outros da agropecuária e Margens, ocorreu ganho refletido pelo aumento do índice IPR/IPP específico para cada um deles. Juntos os referidos setores dão conta de $25 \%$ do consumo intermediário total extra setor da Indústria têxtil. Mais uma vez fica evidente o efeito da desvalorização da taxa de câmbio no sentido do favorecimento dos setores tradables em detrimento dos non-tradables, ou que sejam relativamente menos tradables, como é o caso do setor Outros da agropecuária e Margens. Em contrapartida a Indústria Têxtil, perdeu em relação ao setor Algodão e ao setor Químicos. No primeiro caso deve-se ter atenção para a relação existente entre o setor da Indústria Têxtil e o setor Algodão. Conforme pode ser observado na Tabela 7, 96\% do total de algodão ofertado para consumo intermediário foi destinado para a Indústria Têxtil; por outro lado, esse valor representa apenas 5\% do consumo intermediário total desta, conforme dados da Tabela 6. Sendo assim, qualquer movimento na produção da Indústria Têxtil terá um acentuado impacto sobre a produção de algodão. Com a desvalorização, ocorreu um estímulo positivo para a Indústria Têxtil que passou a demandar mais algodão. A produção de algodão reagiu, mas em função das limitações, principalmente com relação ao estoque de capital, não foi suficiente para suprir a demanda, o que resultou em aumento da importação de algodão mesmo diante de uma desvalorização da taxa de câmbio nominal. 


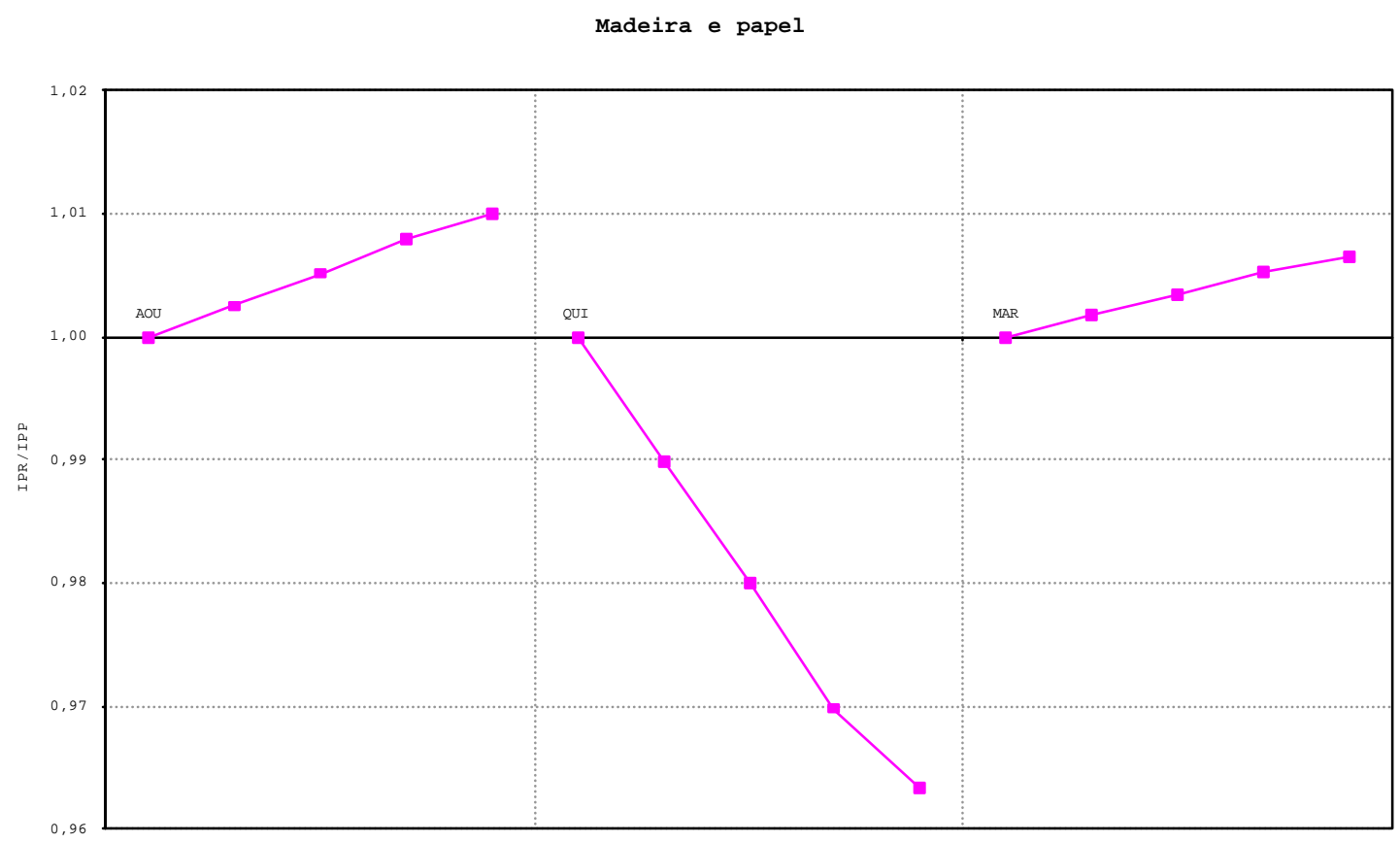

Indústria Têxtil

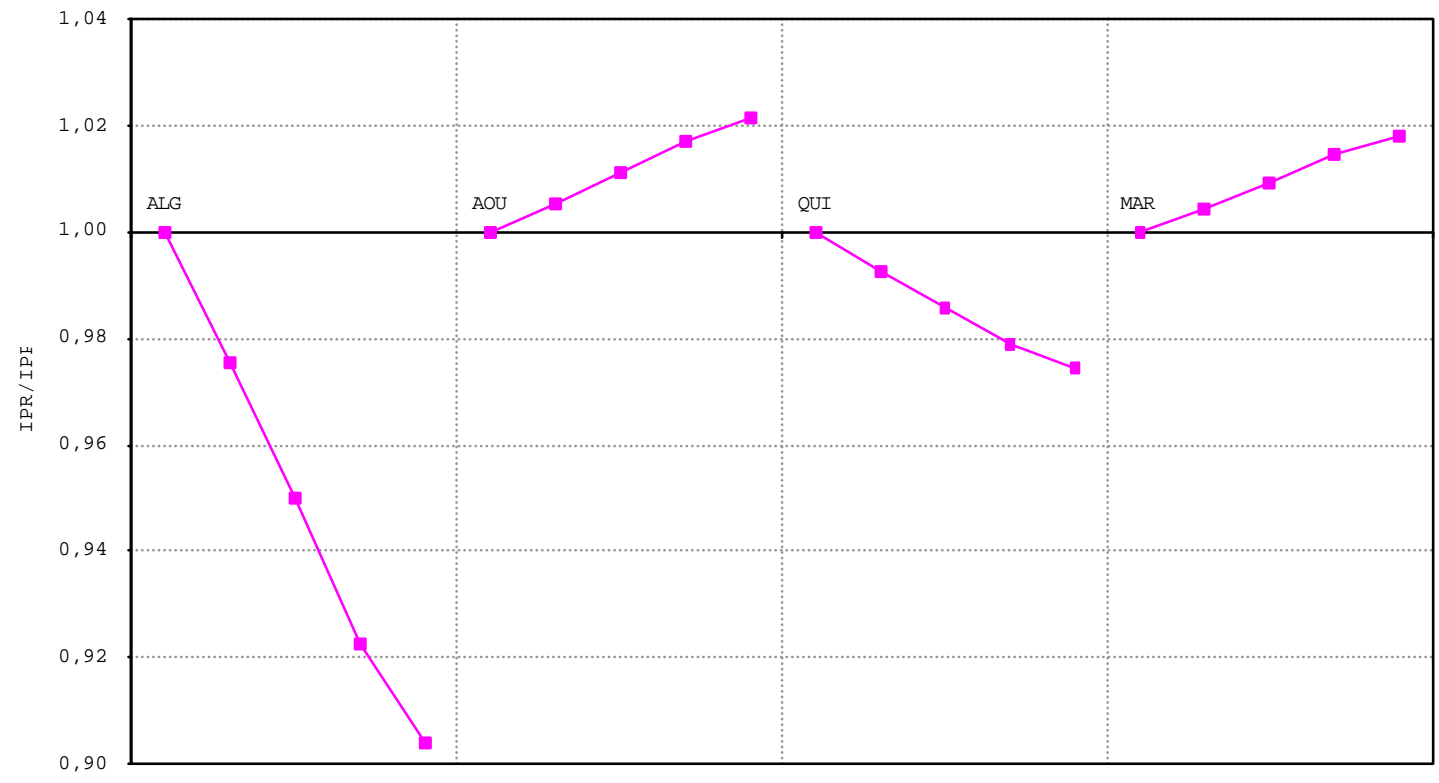

Figura 39 - Variação da relação preço recebido/preço pago em função da desvalorização (setor Madeira/papel e Têxtil). 
O IPR/IPP da Industria do café, quando analisado em relação aos principais setores fornecedores do consumo intermediário, indicam que esta agroindústria perdeu em relação ao setor agropecuário Café, mas ganhou com relação ao setor Margens de comércio e transporte (Figura 40). Este foi um dos exemplos onde o preço composto de um setor da agropecuária aumentou relativamente ao preço para a produção de um setor da agroindustria.

O setor de Beneficiamento de produtos vegetais, por outro lado, se relaciona no consumo intermediário com vários outros setores, conforme pode ser notado na Figura 40. Com relação ao setores agropecuários Arroz e Soja, a agroindústria do Beneficiamento de produtos vegetais não apresentou ganhos, uma vez que, a desvalorização provocou o aumento do preço composto desses setores. Arroz e Soja, dentre os setores agropecuários, possuem uma das maiores parcelas de participação da importação na oferta doméstica, o que contribui para a elevação dos preços compostos. Com relação aos setores Milho e Outros produtos da agropecuária ocorreu ganho em favor do setor de Beneficiamento, dado que esses setores agropecuários foram mais voltados para o mercado interno, assim como o setor Margens de comércio e transporte. Em relação ao setor da Indústria Química a perda observada indica que o setor de Beneficiamento de produtos vegetais se beneficiou menos que o setor da Indústria Química.

Analisando os setores Abate de animais e Indústria de Laticínios (Figura 41), nota-se que ambos apresentaram melhoria do IPR/IPP em relação aos setores Outros da agropecuária e Margens de comércio e transporte. Quanto ao setor Químicos os dois setores apresentaram perda, reforçando que os setores agroindústriais mais voltados para o mercado interno foram prejudicados pela desvalorização em relação aos industriais. Por fim, os setores fornecedores de insumos agropecuários, Bovinos/suínos e Leite Natural, se beneficiaram relativamente aos setores agroindustriais deles dependentes. 

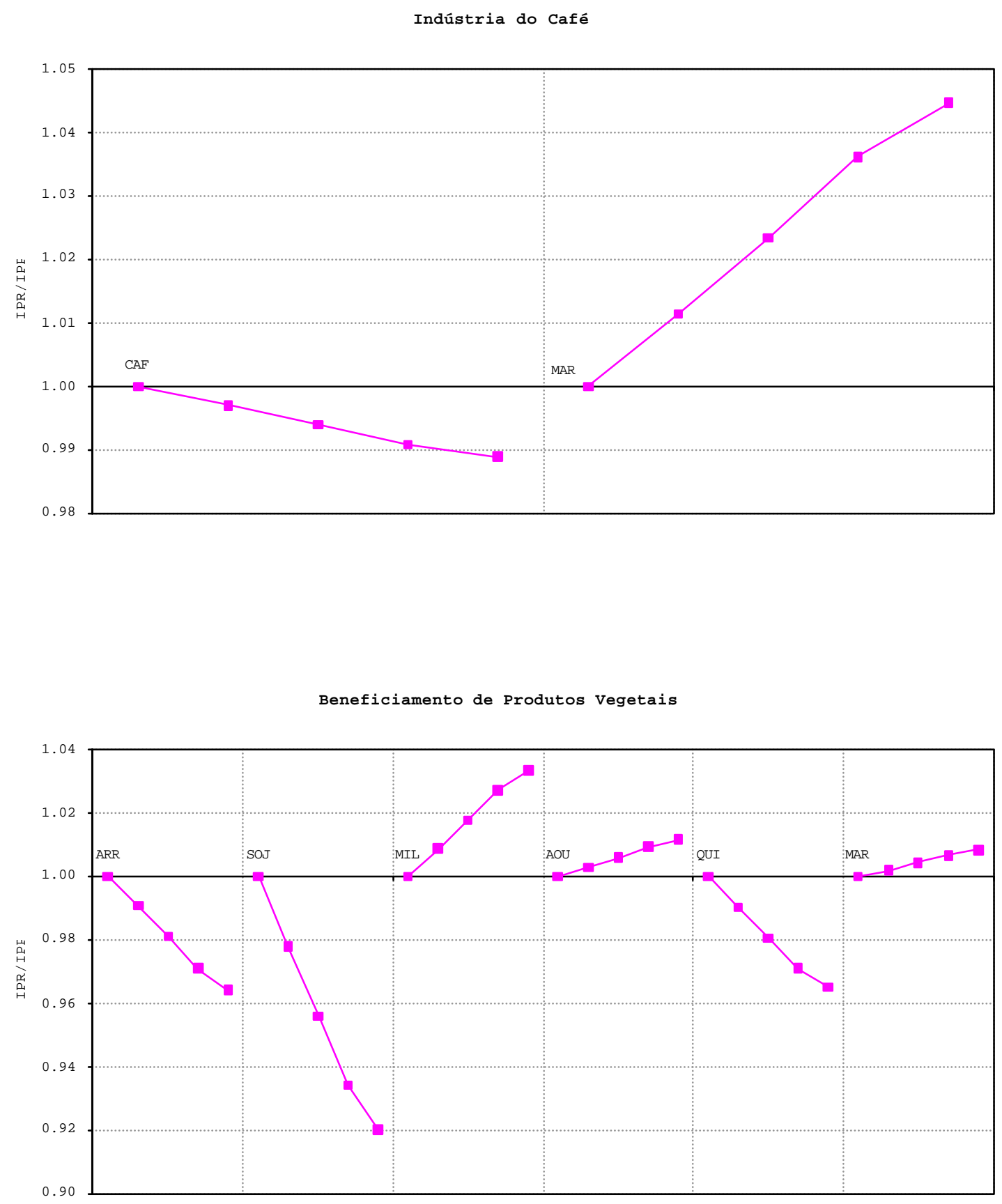

Figura 40 - Variação da relação preço recebido/preço pago em função da desvalorização (setor Indústria do Café e Benefiacimento de produtos vegetais). 

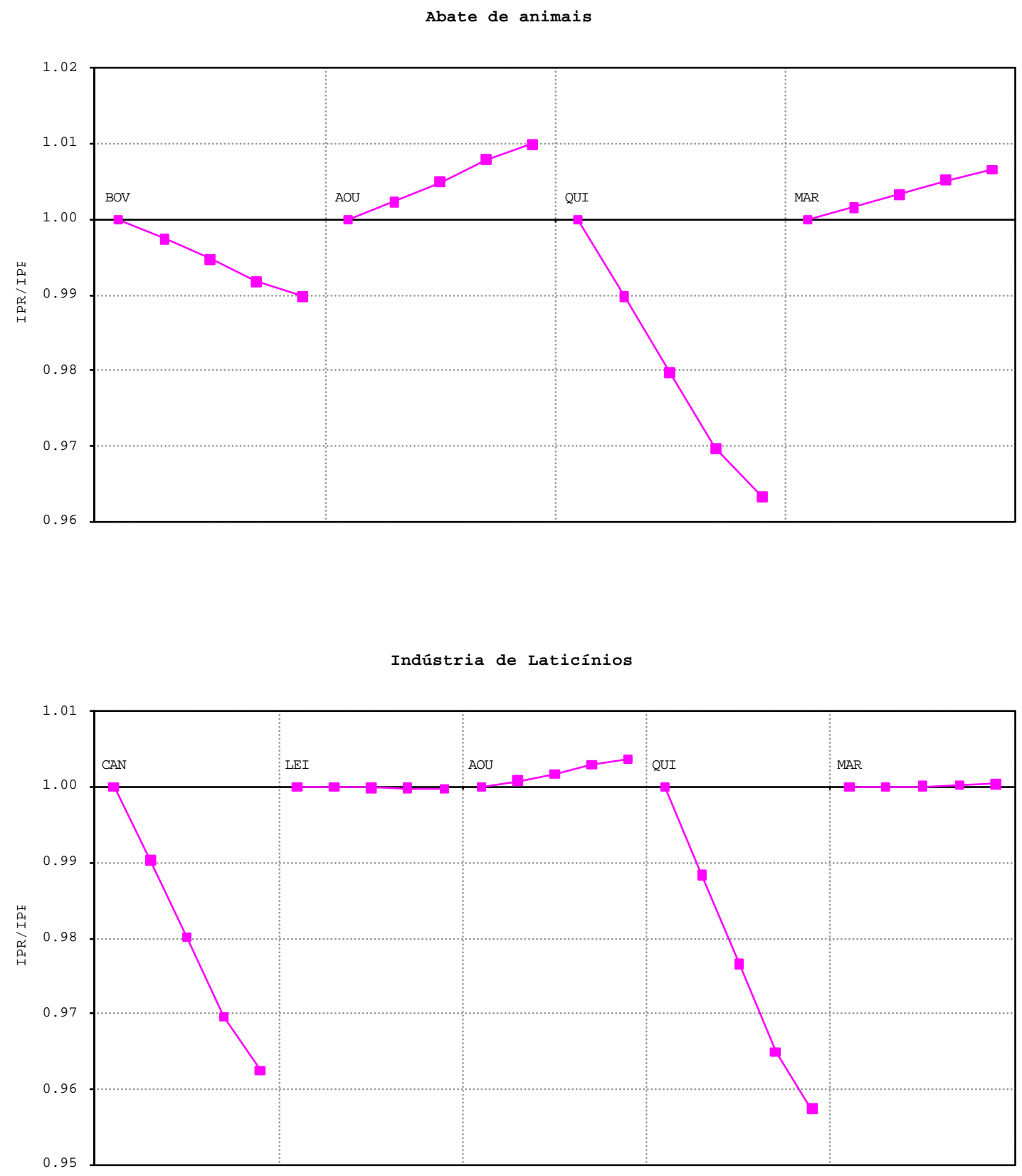

Figura 41 - Variação da relação preço recebido/preço pago em função da desvalorização (setor Abate de animais e Indústria de laticínios). 
$\mathrm{Na}$ Figura 42 analisa-se o IPR/IPP para os principais setores que se relacionam, através do consumo intermediário, com os setores Indústria do Açúcar e Índustria de Óleos vegetais. A Indústria do açúcar se beneficiou em relação aos setores Outros da agropecuária, Máquinas, Indústria Têxtil e Margens. No entanto, em relação ao setor Cana-de-açúcar, que responde por $40 \%$ do consumo intermediário da Indústria do Açúcar (Tabela 5), ocorreu perca de aproximadamente 2\%.

Analisando o caso da Indústria de Óleos vegetais, que consumiu de vários setores agropecuários, percebe-se a distinção entre os setores agropecuários Soja e Algodão e os setores Arroz, Milho, Bovinos/suínos e Outros da agropecuária. A Indústria de Óleos vegetais se beneficiou de uma forma mais intensa da desvalorização quando comparada com os setores da Siderurgia e Químicos. Por outro lado, o benefício não foi observado para os setores fornecedores de insumos agropecuários (soja e algodão).

Finalmente analisando a relação da agroindústria Outros produtos alimentares com os seus fornecedores para consumo intermediário, nota-se que esse setor ao ter sido a agroindústria menos voltada para o mercado externo, não auferiu ganhos em relação à maior parte de seus fornecedores agropecuários, indústriais e de serviços. $\mathrm{Na}$ agropecuária execeção se fez para Leite natural e Outros da agropecuária, setores significativamente prejudicados pela desvalorização. Com relação à relação com outras agroindústrias, constatou-se que ocorreu ganho sobre o setor Beneficiamento de produtos vegetais. Destaca-se que os dois setores são interconectados pois $61 \%$ da oferta para consumo intermediário do setor de Beneficiamento de produtos vegetais foram destinados para o setor Outros produtos alimentares, que por sua vez retornou com 15\% de sua oferta para o mesmo setor de Beneficiamento (Tabela 7).

A partir dos resultados apresentados, percebe-se que ocorreu um melhoria da relação dos setores agropecuários com relação aos seus demandantes agroindústriais, no caso da cana-de-açúcar, café, soja, arroz e algodão. Por outro lado, os setores Milho, Bovinos/suínos, Leite natural e Outros da agropecuária, apresentaram perdas dependendo da agroindústria com a qual se relacionaram. Através da análise dos termos de troca da agroindústria foi possível perceber as diferenças dos efeitos entre os setores agroindustriais, deles com os indústriais e com os setores agropecuários. 

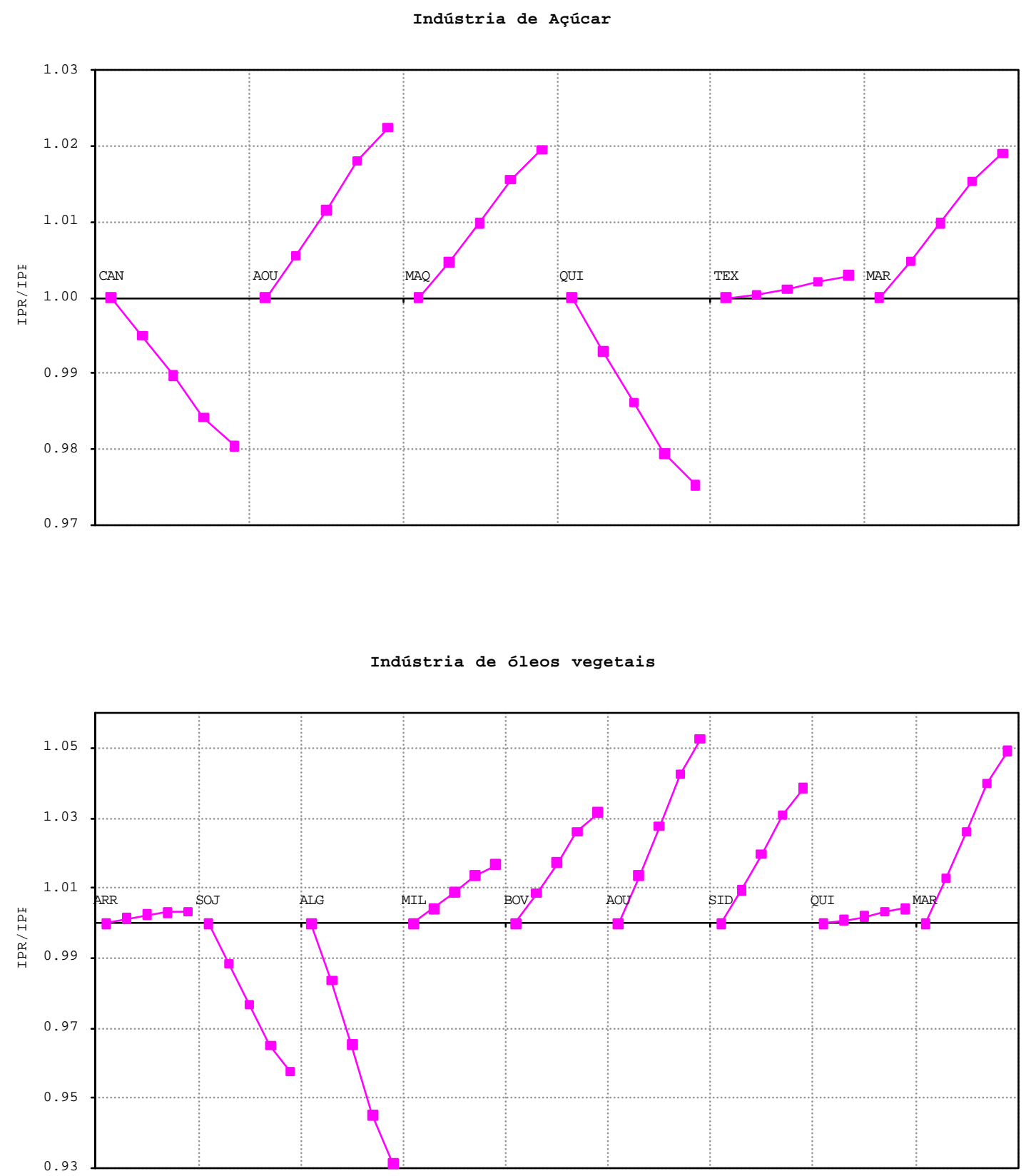

Figura 42 - Variação da relação preço recebido/preço pago em função da desvalorização (setor Indústria do açúcar e Indústria de óleos vegetais). 
Outros produtos alimentares

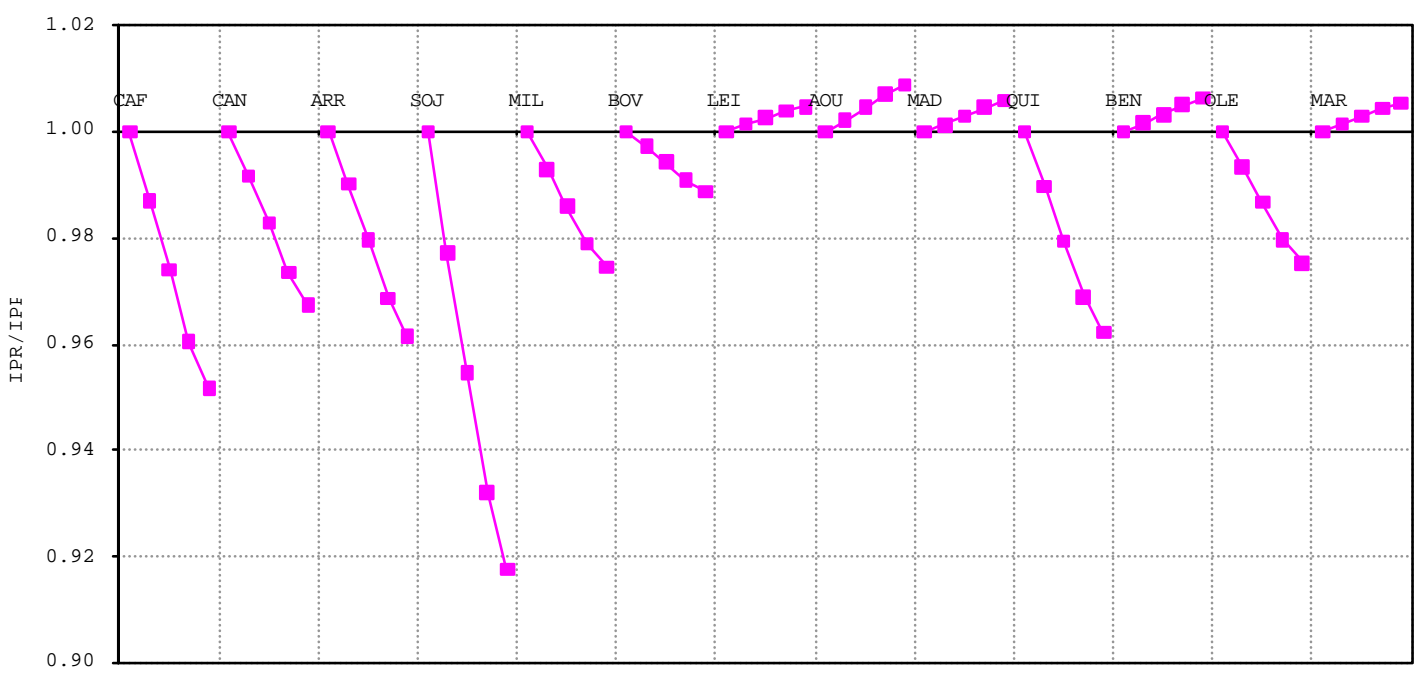

Figura 43 - Variação da relação preço recebido/preço pago em função da desvalorização (setor Outros produtos alimentares). 


\section{CONCLUSÕES}

Partindo de uma base de informação associada à um processo de sobrevalorização da moeda nacional, procedeu-se uma análise contra factual desvalorizando a taxa de câmbio de forma a verificar se a agropecuária e o seu setor agroindustrial obteriam benefícios. Procurou-se verificar, a hipótese de que a sobrevalorização não estaria gerando um sistemático efeito negativo sobre todo o agronegócio brasileiro.

A desvalorização da taxa de câmbio nominal, tendo como numéraire os preços para a produção, correspondeu a uma função monotônica da desvalorização da taxa de câmbio real, conforme foi discutido na Metodologia no ítem 3.1.1.5. Com a alteração de $11,33 \%$ da taxa de câmbio nominal, alterou-se inicialmente os preços em moeda nacional de exportações e importações, que por sua vez afetaram os preços para a produção (composto entre $\mathrm{P}^{\mathrm{E}}$ e $\mathrm{P}^{\mathrm{D}}$ ) e os preços compostos (composto entre $\mathrm{P}^{\mathrm{M}}$ e $\mathrm{P}^{\mathrm{D}}$ ), que desencadearam todo um processo de ajustamento das variáveis quantitativas da economia.

Com relação aos impactos sobre exportações, percebeu-se que o modelo reagiu de forma bastante coerente à observada no mundo real. Observou-se que a maior reação estava atrelada aos setores com alto índice da produção destinada ao mercado externo e que produziam produtos manufaturados. Os setores agropecuários e agroindustriais apresentaram variação de exportações inferiores aos demais setores industriais, o que foi consistente com a evidência empírica.

Sobre o comportamento das importações, a participação destas na oferta total dos setores fornecedores de insumos para a agropecuária (Químicos, adubos e outros químicos), foi um aspecto que reforçou o efeito de aumento de custos em decorrência da 
desvalorização da moeda. Setores com participação de importação mais elevada apresentaram maior elevação do preço composto, que foi aquele pago pela demanda intermediária e pela demanda final da economia.

Face ao impacto sobre as exportações e importações, a produção doméstica foi afetada com intensidade diferenciada, na medida das características de cada setor. Soja e Café foram dois setores que apresentaram elevação do preço diretamente para a produção, por exportarem, e indiretamente, por fornecerem para setores exportadores (Fabricação de óleos vegetais e Indústria do café). Cana, arroz, algodão e milho, foram beneficiados de forma tipicamente indireta, pelas demandas das agroindústrias mais relacionadas com o mercado externo.

O estímulo de preços para a produção da agroindústria foi também associado com o grau de relação com o mercado externo, sendo o grupo de agroindústrias de alimentação (Beneficiamento da produção vegetal, Abate de animais, Laticínios e Outros produtos alimentares) o que auferiu menor elevação do preço para a produção. Este fato reforçou a menor contribuição indireta, exercida pelas agroindústrias de alimentação, em relação aos setores fornecedores agropecuários (Milho, Arroz, Bovinos/suínos, Leite natural e Outros produtos da agropecuária).

Analisando o efeito conjunto, advindo do ajustamento do preço para a produção e da quantidade produzida por cada setor, observou-se que o grupo de setores agropecuários tradables de exportação sofreu um estímulo da ordem de 8,8\% no valor da produção, seguidos pelo grupo tradables substitutos de importação com $2 \%$ e setor Outros da agropecuária com $-0,5 \%$. Este comportamento observado para a estrutura produtiva do ano de 1995, tendo em vista as pressuposições e formas funcionais adotadas no modelo, apoia a hipótese de que a agropecuária não foi afetada unicamente de forma negativa pelo processo de sobrevalorização. A parcela com características non-tradable da agropecuária, representada na estrutura pelo setor Outros da agropecuária, respondeu negativamente à desvalorização ou positivamente à sobrevalorização. Cabe destacar ainda, que o comportamento do setor Outros da agropecuária não pode ser desprezado, uma vez que, representava na estrutura de 1995, $56 \%$ do valor da produção total agropecuária. 
Buscando investigar a origem do comportamento observado na produção, foi possível constatar, através da análise dos índices de preços que os setores agropecuários, independente de serem tradables ou não, foram afetados de forma similar no custo de produção extra setor, o que não aconteceu para o preço para a produção. Este fato constitui um dos elementos que prejudicaram a parcela non-tradable, que se deparou com aumento de custos, mas não com um aumento dos preços para a produção.

Ao se analisar a relação IPR/IPP (preços recebidos $\mathrm{x}$ preços pagos), tornou-se clara a questão da perda em relação à defensivos e fertilizantes (no modelo, representados pelos setores Químicos, Outros químicos e Adubos), que por terem uma significativa base importada, apresentaram aumento superior do preço composto em comparação ao preço recebido pelos setores agropecuários, com exceção de Café, Soja e Algodão.

Da substituição de importação ao processo de abertura comercial, observou-se as marcantes influências das políticas macroeconômicas sobre a agropecuária. Este trabalho chamou a atenção para o fato de que, mesmo no caso do câmbio variar em uma direção favorável à exportação, dada a estrutura da economia brasileira, não se pode desconsiderar os resultantes efeitos sobre custos e preços relativos, os quais não atuam de forma positiva única sobre as várias culturas, regiões e cadeias agroindustriais. O fundamento destacado por Dornbusch (1987), referente à alteração de preços relativos gerada pela taxa de câmbio, ser mais ou menos significativa conforme o grau de relação com o mercado internacional, ficou evidenciado nos resultados obtidos.

Cabe destacar também que a desvalorização, efetuada a partir de um contexto de sobrevalorização da moeda nacional, gerou efeito positivo para os setores tradables de exportação. Para o caso dos setores tradables substitutos de importados, notou-se uma menor reação, ainda de sentido positivo. E para os setores non-tradables (Bovinos/suínos, Leite natural e Outros da agropecuária), o efeito foi caracteristicamente prejudicial. Esse padrão de resposta está plenamente de acordo com os aspectos teóricos associados à existência de bens tradables e non-tradables discutidos por Dornbusch (1987), Güzel \& Kulshrestsha (1995), Mamingi (1996), Shiff \& Valdés (1998) e Helfand \& Rezende (2001). 
O fato novo apresentado neste trabalho foi referente ao reconhecimento do tamanho da parcela non-tradable do agronegócio brasileiro, freqüentemente desconsiderado nas análises dos efeitos negativos da sobrevalorização sobre as exportações. Argumentações como as realizadas por Mamingi (1996) e Schuh (1998), estavam focadas apenas nos setores exportadores, cujo comportamento não pode ser extrapolado para o restante da agropecuária e agroindústria brasileiras, com relações intersetoriais muito mais complexas que aquelas circunscritas ao processo de exportação.

Com o tratamento dado às relações externas, quando se considerou a existência de substituição e transformação imperfeitas, foi possível garantir a coerência das relações causais (validade interna) dos movimentos dos preços relativos domésticos em resposta às alterações dos preços em moeda nacional das exportações e importações. No modelo, a alteração dos preços de exportação e importação foi parcialmente transmitida para os preços domésticos, na medida do grau com que o setor se relacionou com o mercado externo e do valor das elasticidades de substituição e transformação consideradas. Este tratamento se contrapôs ao freqüentemente adotado nos modelos de equilíbrio parcial, quando assume-se a substituição perfeita. Deixou-se assim de considerar os setores de forma extremamente especializada, permitindo a existência de setores tradables com grau intermediário, além de se permitir o "cross-hauling" nas exportações e importações.

Outro importante aspecto, que permitiu a maior adequação do modelo à problemática que ele visava tratar, foi a consideração das relações inter-setoriais, que ficaram evidenciadas no comportamento resultante dos índices IPR/IPP. Com esse tratamento, ficou bem delineada a questão de que a desvalorização resultou em aumento de custos de insumos (defensivos e fertilizantes). Este aumento foi compensado pelos ganhos obtidos pelos setores exportadores. Por outro lado, os setores non-tradables não tiveram o mesmo benefício, perdendo em termos de troca. Esta observação evidencia a importância, para a agropecuária, da maneira como se estruturam estes mercados agroindustriais, uma vez que parcela importante de seus estímulos de demanda se processam por esta via. Este é um aspecto a ser melhor considerado em estudos futuros. 
Ainda sobre as relações inter-setoriais, destacam-se os resultados que relacionaram os setores agropecuários e os agroindustriais, como sendo um outro importante elemento de propagação do choque gerado pela desvalorização da taxa de câmbio. Observou-se que setores agropecuários se beneficiaram indiretamente, através do efeito de demanda das agroindústrias, estas sim diretamente afetadas pelas modificações geradas pela desvalorização.

Quando se parte para um processo de modelagem, os tradeoffs entre complexidade do modelo e entendimento pleno das suas reações sempre estarão presentes. A decisão tomada neste trabalho, ao se adotar um modelo de equilíbrio geral com o adequado tratamento do ponto crucial (relações externas), mas com simplificações nas fórmulas funcionais e no tratamento do valor adicionado, foi um opção considerada correta frente aos resultados que foram possíveis de serem obtidos. Naturalmente, as possibilidade de novos incrementos em complexidade corresponderiam um importante passo para novos trabalhos. Sugere-se a adoção de formas funcionais que permitam maior grau de substituição entre fatores de produção, além de se considerar o fator capital subdivido para explicitar o fator terra na agropecuária.

Em futuros trabalhos também deve ser dada a devida atenção aos possíveis efeitos distributivos da desvalorização cambial, uma vez que a pequena produção agropecuária brasileira poderia ser caracterizada como non-tradable e assim sendo estaria sendo prejudicada por eventuais desvalorizações. Ao mesmo tempo, o estímulo aos setores agropecuários de exportação, poderia estar associado ao estímulo à produção de grande escala e alta tecnificação. 
ANEXOS 
ANEXO A - Variáveis e parâmetros do modelo

\section{Variáveis endógenas:}

\begin{tabular}{|c|c|c|c|}
\hline Variável & Descrição & Índice & Comentário \\
\hline$C G_{i}$ & consumo público do bem i & $i$ & \\
\hline$C_{i}$ & consumo final do brm & $i$ & \\
\hline$C I_{i}$ & consumo intermediário & $i$ & \\
\hline$C I J_{i j}$ & consumo intermediário do bem & ij & \\
\hline$C M_{i}$ & consumo das famílias & i & \\
\hline CTM & consumo total das famílias & 1 & \\
\hline$D I_{i}$ & demanda intermediária do bem & $i$ & \\
\hline$D I V$ & dividendos das famílias & 1 & \\
\hline$D_{n}$ & demanda interna de produto doméstico & $\mathrm{n}$ & \\
\hline e & Taxa de câmbio nominal (R\$/US\$) & 1 & \\
\hline$E \boldsymbol{X}_{n}$ & volume das exportações FOB & $\mathrm{n}$ & \\
\hline ETT & Estoque total (valor) & 1 & \\
\hline$I N V_{i}$ & investimento em bem & i & \\
\hline$I T$ & Investimento total & 1 & Neoclássico \\
\hline$L^{D_{i}}$ & demanda por trabalho & $i$ & Pleno emprego \\
\hline$M_{n}$ & volume das importações CIF & $\mathrm{n}$ & \\
\hline $\boldsymbol{P}_{\boldsymbol{i}}$ & preço do produto do setor & $i$ & \\
\hline$P_{i}{ }^{C}$ & preço do produto composto & $i$ & \\
\hline$P_{n}{ }^{D}$ & preço da produção doméstica & $\mathrm{n}$ & \\
\hline$P_{n}{ }^{E}$ & preço local das exportações & $\mathrm{n}$ & \\
\hline$P_{n}{ }^{M}$ & preço local das importações & $\mathrm{n}$ & \\
\hline$P_{n}^{V A}$ & preço do valor adicionado & $\mathrm{n}$ & \\
\hline $\boldsymbol{Q}_{i}$ & demanda interna do produto composto & $i$ & \\
\hline$R E$ & renda do capital das empresas & 1 & \\
\hline$R_{n}$ & rendimento do capital & $\mathrm{n}$ & \\
\hline Se & poupança das empresas & 1 & Neoclássico \\
\hline$s g$ & poupança do governo & 1 & Neoclássico \\
\hline$S m$ & poupança das famílias & 1 & Neoclássico \\
\hline$T X E_{n}$ & imposto de exportação & $\mathrm{n}$ & \\
\hline $\mathbf{T X M} M_{n}$ & impostos de importação & $\mathrm{n}$ & \\
\hline$T X S_{i}$ & impostos indiretos & $i$ & \\
\hline$V \boldsymbol{A}_{i}$ & valor adicionado & i & \\
\hline $\boldsymbol{W}$ & salário & 1 & \\
\hline$X_{i} S$ & produção setorial & i & \\
\hline$Y D m$ & renda disponível das famílias & 1 & \\
\hline Ye & renda das empresas & 1 & \\
\hline$Y g$ & renda do governo & 1 & \\
\hline$Y m$ & renda total famílias & 1 & \\
\hline LEON & $\begin{array}{l}\text { Variável de controle da identidade de } \\
\text { Walras }\end{array}$ & 1 & \\
\hline
\end{tabular}


Variáveis exógenas:

\begin{tabular}{|c|c|c|c|}
\hline Variável & Descrição & Índice & Comentários \\
\hline$B C$ & balanço de transações correntes & 1 & $\begin{array}{c}\text { Fechamento externo - } \\
\text { US\$ }\end{array}$ \\
\hline $\boldsymbol{K}_{n}$ & Estoque de capital & $\mathrm{n}$ & $\begin{array}{l}\text { Admite-se sua plena } \\
\text { utilização }\end{array}$ \\
\hline$P_{n} W E$ & $\begin{array}{l}\text { Preço em moeda externa das } \\
\text { exportações }\end{array}$ & $\mathrm{n}$ & Fechamento externo \\
\hline$P_{n} W M$ & $\begin{array}{l}\text { Preço em moeda externa das } \\
\text { importações }\end{array}$ & $\mathrm{n}$ & Fechamento externo \\
\hline Ter & $\begin{array}{l}\text { Transferência das empresas p/ resto } \\
\text { do mundo }\end{array}$ & 1 & Fechamento externo \\
\hline Trm & $\begin{array}{l}\text { Transferências do resto do mundo p/ } \\
\text { famílias }\end{array}$ & 1 & Fechamento externo \\
\hline $\operatorname{Trg}$ & $\begin{array}{l}\text { Transferências do resto do mundo p/ } \\
\text { governo }\end{array}$ & 1 & $\begin{array}{l}\text { Financiamento externo } \\
\text { do setor público }\end{array}$ \\
\hline PINDEX & Índice de preços & 1 & Numéraire \\
\hline$L^{S}$ & Oferta total de trabalho & 1 & Pleno emprego \\
\hline$C T_{G}$ & Consumo público total & 1 & Setor público \\
\hline Tge & Transferências públicas p/ empresas & 1 & Setor público \\
\hline$E s t_{i}$ & Estoque em bem & $i$ & \\
\hline
\end{tabular}

Variáveis intermediárias utilizadas apenas no cálculo dos parâmetros:

\begin{tabular}{lrcc}
\hline Variável & \multicolumn{1}{c}{ Descrição } & Índice & Comentários \\
\hline $\mathbf{R E I}$ & Receita do capital destinada às famílias & $\mathbf{1}$ & \\
$\mathbf{T X Y}$ & Imposto de renda sobre as famílias & $\mathbf{1}$ & \\
$\mathbf{T X K}$ & Imposto de renda sobre as empresas & $\mathbf{1}$ & \\
\hline
\end{tabular}




\section{Parâmetros do modelo:}

\begin{tabular}{|c|c|c|}
\hline Parâmetros & Cálculo & Descrição \\
\hline$a_{n}$ & $V A_{n}$ & \multirow{2}{*}{$\begin{array}{l}\text { Coeficiente de escala do } \\
\text { valor adicionado }\end{array}$} \\
\hline & $a_{n}=\overline{\left(\left(L_{n}^{D}\right)^{\alpha \cdot} \times\left(K_{n}\right)^{\left(1-\alpha_{n}\right)}\right)}$ & \\
\hline & $W \times L_{n}^{D}$ & \multirow{2}{*}{$\begin{array}{l}\text { Participação do salário no } \\
\text { valor adicionado }\end{array}$} \\
\hline$\alpha_{n}$ & $\alpha_{n}=\overline{\left(W \times L_{n}^{D}+R_{n} \times K_{n}\right)}$ & \\
\hline$a_{y}$ & $a_{i j}=C I J_{i j} / C I_{i}$ & \multirow{4}{*}{$\begin{array}{l}\text { Coeficiente técnico do } \\
\text { consumo intermediário } \\
\text { Parcela da receita do capital } \\
\text { destina às famílias } \\
\text { Taxa de repasse de } \\
\text { dividendos às familias }\end{array}$} \\
\hline$\lambda$ & $\lambda=R E I / \Sigma_{n}\left(R_{n} \times K_{n}\right)$ & \\
\hline & DIV & \\
\hline$t d v$ & $t d v=\overline{(1-\lambda) \times \sum_{n} R_{n} \times K_{n}}$ & \\
\hline pms & $p m s=S m / Y D m$ & $\begin{array}{c}\text { Propensão marginal a } \\
\text { poupar }\end{array}$ \\
\hline ty & $t y=T X Y / Y m$ & Imposto de renda - famílias \\
\hline tk & $T X K$ & \multirow{2}{*}{ Imposto de renda - empresas } \\
\hline$t K$ & $K=\overline{(1-\lambda) \times \sum_{n} R_{n} \times K_{n}}$ & \\
\hline$t x_{i}$ & $\mathrm{tx}_{\mathrm{i}}=\mathrm{TXS}_{\mathrm{i}} /\left(\mathbf{P}_{\mathrm{i}} \times \mathrm{X}_{\mathrm{i}}^{\mathrm{S}}\right)$ & Imposto indireto \\
\hline$t m_{n}$ & $t m_{n}=\frac{T X M_{n}}{\left(P_{n}^{T M} \times e \times M_{n}\right)}$ & Imposto sobre importação \\
\hline$t e_{n}$ & $T X E_{n}$ & \multirow{2}{*}{ Imposto sobre exportação } \\
\hline & $\left(P_{n}^{s} \times E X_{n}\right)$ & \\
\hline$\beta_{i}^{e}$ & $\beta_{i}^{c}=\frac{P_{i}^{C} \times C M_{i}}{C T M}$ & $\begin{array}{l}\text { Participação do bem i no } \\
\text { consumo famflias }\end{array}$ \\
\hline$\beta^{\beta}$ & $\beta_{i}^{G}=\frac{P_{i}^{C} \times C G_{i}}{C T G}$ & $\begin{array}{l}\text { Participação do bem i no } \\
\text { consumo governo }\end{array}$ \\
\hline$\beta_{t}^{I}$ & $\beta_{i}^{I}=\frac{P_{i}^{C} \times I N V_{i}}{I T}$ & $\begin{array}{l}\text { Participação do bem i no } \\
\text { investimento total }\end{array}$ \\
\hline$\beta_{i}^{X}$ & $\beta_{t}^{X}=\frac{X_{i}^{S}}{\sum_{i} X_{t}^{S}}$ & $\begin{array}{l}\text { Participação do bem i na } \\
\text { produçăo total }\end{array}$ \\
\hline
\end{tabular}




\begin{tabular}{|c|c|c|}
\hline Parâmetros & Cálculo & Descrição \\
\hline$\beta_{i}^{E}$ & $\beta_{i}^{E}=\frac{P_{i}^{C} \times E S T_{i}}{E T T}$ & $\begin{array}{l}\text { Participação do bem i no } \\
\text { estoque total }\end{array}$ \\
\hline $\boldsymbol{b}_{n}{ }^{T}$ & 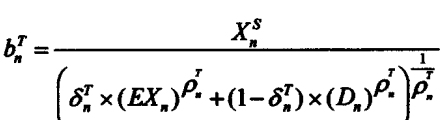 & $\begin{array}{l}\text { Parâmetro de dimensão } \\
\text { da função CET }\end{array}$ \\
\hline$\delta_{n}^{T}$ & $\delta_{n}^{T}=\frac{1}{\left(\frac{\left(1+P_{n}^{D}\right)}{P_{n}^{E}}\right) \times\left(\frac{E X_{n}}{D_{n}}\right)^{\left(\rho_{n}^{T}-1\right)}}$ & $\begin{array}{l}\text { Parâmetro de proporção } \\
\text { da função CET }\end{array}$ \\
\hline$\rho_{n}^{T}$ & $\rho_{n}^{T}=\frac{\left(1+\sigma_{n}^{T}\right)}{\sigma_{n}^{T}}$ & Expoente da função CET \\
\hline$\sigma_{n}{ }^{\top}$ & Exógena & $\begin{array}{l}\text { Elasticidade de } \\
\text { transformação }\end{array}$ \\
\hline$b_{n}{ }^{S}$ & $b_{n}^{S}=\frac{Q_{n}}{\left(\delta_{n}^{S} \times\left(M_{n}\right)^{-\rho_{n}^{s}}+\left(1-\delta_{n}^{s}\right) \times\left(D_{n}\right)^{\left.-\rho_{n}^{s}\right)}\right)^{\frac{-1}{\rho_{n}^{s}}}}$ & $\begin{array}{l}\text { Parâmetro de dimensão } \\
\text { da função Armington }\end{array}$ \\
\hline$\delta_{n}^{S}$ & $\delta_{n}^{S}=\frac{\left(P_{n}^{n}\right)\left(D_{n}\right)}{\left(\left(\underline{P}_{n}^{M}\right) \times\left(\mid M_{n}\right)^{\frac{1}{\sigma_{n}^{s}}}\right.}$ & $\begin{array}{l}\text { Parâmetro de proporção } \\
\text { da funçã̃o Armington }\end{array}$ \\
\hline$\rho_{n}^{S}$ & $\rho_{n}^{S}=\frac{\left(1-\sigma_{n}^{S}\right)}{\sigma_{n}^{S}}$ & $\begin{array}{l}\text { Expoente da função } \\
\text { Armington }\end{array}$ \\
\hline$\sigma_{n}^{s}$ & Exógena & $\begin{array}{l}\text { Elasticidade de } \\
\text { substituicão }\end{array}$ \\
\hline$i o_{i}$ & $i o_{i}=C I_{i} / X_{i}^{S}$ & $\begin{array}{l}\text { Participação do consumo } \\
\text { intermediário na } \\
\text { producão }\end{array}$ \\
\hline$v_{n}$ & $v_{n}=V A_{n} / X_{n}^{S}$ & $\begin{array}{l}\text { Participação do valor } \\
\text { adicionado na produção }\end{array}$ \\
\hline
\end{tabular}




\section{ANEXO B - Equações do modelo}

\begin{tabular}{|c|c|c|}
\hline GRUPO PRODUÇÃO & $\begin{array}{l}\text { Núme- } \\
\text { ro }\end{array}$ & Descriçăo \\
\hline $1-X_{i}^{s}=C I_{i} / i o_{i}$ & $\overline{\mathbf{i}}$ & $\begin{array}{l}\text { Produçăo setorial a custo de fatores - } \\
\qquad \text { LF }\end{array}$ \\
\hline $2-C I_{i}=\left(i o_{i} \times V A_{i}\right) / v_{i}$ & $\mathbf{i}$ & $\begin{array}{l}\text { Consumo intermediario total por } \\
\text { setor - LF }\end{array}$ \\
\hline $\left.3-\quad V A_{n}=a_{n} \times\left(L D_{n}^{\alpha_{n}} \times K_{n}^{(1-} \alpha_{n}\right)\right)$ & $\mathbf{n}$ & Valor adicionado setorial - CD \\
\hline $4-L D_{n} \times \mathrm{W}=\left(P_{n}^{V A} \times V A_{n} \times \alpha_{n}\right)$ & $\mathbf{n}$ & Demanda setorial por trabalho - CD \\
\hline $5-C I J_{i j}=a_{i j} \times C I_{j}$ & $\mathrm{i}^{\wedge} 2$ & Consumo intermediario setorial \\
\hline $6-V A_{a d}=L_{a d}^{D}$ & 1 & $\begin{array}{l}\text { Valor adicionado do setor } \\
\text { administrativo }\end{array}$ \\
\hline $7-L_{a d}{ }^{D}=\left(P_{a d} \times X_{a d}{ }^{S}-\Sigma_{j} P_{j} C \times C I J_{i a d}\right) / W$ & 1 & $\begin{array}{l}\text { Demanda do setor administrativo por } \\
\text { trabalho }\end{array}$ \\
\hline \multicolumn{3}{|l|}{ GRUPO RENDA E POUPANÇA } \\
\hline $8-Y_{M}=W \times \Sigma_{i} L_{i}^{D}+D I V+\lambda \times \Sigma_{n} R_{n} \times K_{n}+e \times T_{R M}$ & 1 & Renda total das famllias \\
\hline 9-RE $=(1-\lambda) \times \Sigma_{n} R_{n} \times K_{n}$ & 1 & Renda apropriada pelas empresas \\
\hline $10-D I V=t d v \times R E$ & 1 & Dividendos repassedos as famllias \\
\hline $11-S_{M}=p m s \times Y D_{M}$ & 1 & Poupança as famellias \\
\hline $12-Y D_{M}=(1-t y) \times Y_{M}$ & 1 & Renda disponivel das familias \\
\hline $13-Y_{E}=R E+P I N D E X \times T_{G E}$ & 1 & Renda total das empresas \\
\hline $14-S_{E}=Y_{E}-t k \times R E-D I V-T_{E R}$ & 1 & Poupancas das empressas \\
\hline $15-Y_{G}=t y \times Y_{M}+t k \times R E+\Sigma_{j} T X S_{i}+e \times T_{R G}+$ & 1 & Renda do governo \\
\hline \multicolumn{3}{|l|}{$\Sigma_{n} T X M_{n}+\Sigma_{n} T X E_{n}$} \\
\hline $16-T X S_{i}=t x_{i} \times P_{i} \times X_{i}^{S}$ & i & Taxas sobre a produçato \\
\hline $17-T X M_{n}=t m_{n} \times e \times P_{n}{ }^{W M} \times M_{n}$ & $\mathbf{n}$ & Taxas sobre a importaçilo \\
\hline $18-T X E_{n}=t e_{n} \times P_{n}^{E} \times E X_{n}$ & $\mathbf{n}$ & Taxas sobre a exportaçilo \\
\hline $19-S_{G}=Y_{G}-P I N D E X \times T_{G E}-C T_{G}$ & 1 & Poupanca do governo \\
\hline
\end{tabular}




\begin{tabular}{|c|c|c|}
\hline GRUPO DEMANDA & Número & Descrição \\
\hline $20-C T M=Y D M-S M$ & 1 & $\begin{array}{l}\text { Consumo total } \\
\text { das familias }\end{array}$ \\
\hline $21-C M i=\beta_{i}^{c} \times C T_{M} / P_{i}^{C}$ & I & $\begin{array}{l}\text { Consumo das } \\
\text { familias em } \\
\text { produto }\end{array}$ \\
\hline $22-C G i=\beta_{i}^{G} \times C T_{G} / P_{i}^{C}$ & i & $\begin{array}{l}\text { Consumo público } \\
\text { em produto }\end{array}$ \\
\hline $23-C_{i}=C M_{i}+C G_{i}$ & $\mathbf{i}$ & $\begin{array}{l}\text { Consumo total } \\
\text { em produto }\end{array}$ \\
\hline $24-I N V_{i}=\beta_{i}^{I} \times I T / P_{i}^{C}$ & $\mathrm{i}$ & $\begin{array}{l}\text { Investimento em } \\
\text { produto }\end{array}$ \\
\hline $25-D I i=\Sigma_{j} a_{i j} \times C I_{j}$ & $\mathrm{i}$ & $\begin{array}{c}\text { Demanda } \\
\text { intermodiária }\end{array}$ \\
\hline \multicolumn{3}{|l|}{ GRUPO COMÉRCIO EXTERIOR } \\
\hline $26-X_{n}^{S}=b_{n}^{T} \times\left[\delta_{n}^{T} \times E X_{n}^{\left(\rho_{n}^{T}\right)}+\left(1-\delta_{n}^{T}\right) \times D_{n}^{\left(\rho_{n}^{T}\right)}\right]\left(\frac{1}{\rho_{n}^{T}}\right)$ & $\mathrm{n}$ & Funshlo CET \\
\hline 27 - $E X_{n}=\left[\left(\frac{P_{n}^{E}}{P_{n}^{D}}\right)^{\sigma_{n}^{T}} \times\left(\frac{\left(1-\delta_{n}^{T}\right)}{\delta_{n}^{T}}\right)^{\sigma_{n}^{T}}\right] \times D_{n}$ & $\mathbf{n}$ & $\begin{array}{l}\text { Oferta de } \\
\text { exportachlo }\end{array}$ \\
\hline $28-Q_{n}=b_{n}^{S} \times\left[\delta_{n}^{S} \times M_{n}^{\left(-\rho_{n}^{S}\right)}+\left(1-\delta_{n}^{S}\right) \times D_{n}^{\left(-\rho_{n}^{S}\right)}\right]\left(\frac{-1}{\rho_{n}^{S}}\right)$ & $\mathbf{n}$ & $\begin{array}{l}\text { Funchlo } \\
\text { Armington } \\
\text { (CES) }\end{array}$ \\
\hline 29 - $\quad M_{n}=\left[\left(\frac{\delta_{n}^{S}}{\left(1-\delta_{n}^{S}\right)}\right)^{\sigma_{n}^{S}} \times\left(\frac{P_{n}^{D}}{P_{n}^{M}}\right)^{\sigma_{n}^{S}}\right] \times D_{n}$ & $\cdot \mathbf{n}$ & $\begin{array}{l}\text { Demanda de } \\
\text { importacilo }\end{array}$ \\
\hline $30-X_{\mathrm{ad}}{ }^{S}=Q_{\mathrm{ad}}-\left(M_{\mathrm{ad}}+T X M_{\mathrm{ad}}\right)-T X S_{\mathrm{ad}}+E X_{\mathrm{ad}}$ & 1 & $\begin{array}{l}\text { Utilizactlo do } \\
\text { servico } \\
\text { administrativo }\end{array}$ \\
\hline $31-B C=\Sigma_{n} P_{n}^{W N} \times M_{n}+(1 / e) \times T_{E R}-\Sigma_{n} P_{n}^{W E} \times E X_{n}-$ & 1 & $\begin{array}{l}\text { Balanço corrente } \\
\text { em divisas }\end{array}$ \\
\hline$T_{R M}-T_{R G}$ & & \\
\hline
\end{tabular}




\section{GRUPO PREÇO}

\begin{tabular}{|c|c|c|}
\hline $\begin{array}{l}32-P_{\mathrm{n}} \times\left(1+t x_{\mathrm{n}}\right)=\left(D_{\mathrm{n}} / X_{\mathrm{n}}^{S}\right) \times P_{\mathrm{n}}^{D}+\left(E X_{\mathrm{n}} /\right. \\
\left.X_{\mathrm{n}}^{S}\right) \times P_{\mathrm{n}}^{E}\end{array}$ & $\mathbf{n}$ & $\begin{array}{l}\text { Preço para a } \\
\text { produçăo }\end{array}$ \\
\hline $33-P_{\mathrm{n}}^{V A}=\left(P_{\mathrm{n}} \times X_{\mathrm{n}}^{S}-\Sigma_{j} P_{\mathrm{j}}^{C} \times C I J_{\mathrm{jn}}\right) / V A_{\mathrm{n}}$ & $\mathbf{n}$ & $\begin{array}{l}\text { Preço do valor } \\
\text { adicionado }\end{array}$ \\
\hline $34-P_{\mathrm{n}}{ }^{M}=\left(1+t m_{n}\right) e \times P_{\mathrm{n}}^{W M}$ & $\mathrm{n}$ & $\begin{array}{l}\text { Preço das } \\
\text { importaçסes }\end{array}$ \\
\hline $35-P_{\mathrm{n}}^{E}=e \times P_{\mathrm{n}}^{W E} /\left(1+t e_{\mathrm{n}}\right)$ & $\mathbf{n}$ & $\begin{array}{l}\text { Preço das } \\
\text { exportaç̧es }\end{array}$ \\
\hline $36-P_{\mathrm{n}}^{C}=\left(D_{\mathrm{n}} / Q_{\mathrm{n}}\right) \times P_{\mathrm{n}}^{D}+\left(M_{\mathrm{n}} / Q_{\mathrm{n}}\right) \times P_{\mathrm{n}}{ }^{M}$ & $\mathbf{n}$ & $\begin{array}{l}\text { Preço dos bens } \\
\text { compostos }\end{array}$ \\
\hline $37-P_{\mathrm{ad}}{ }^{C}=P_{\mathrm{ad}}$ & 1 & $\begin{array}{l}\text { Prece dos } \\
\text { servicos } \\
\text { administrativos }\end{array}$ \\
\hline $38-R_{\mathrm{n}}=\left(P_{\mathrm{n}}^{V A} \times V A_{\mathrm{n}}-W \times L_{\mathrm{n}}^{D}\right) / K_{\mathrm{n}}$ & n & $\begin{array}{l}\text { Remuneraçăo do } \\
\text { capital por setor }\end{array}$ \\
\hline 39- PINDEX $=\Sigma_{i} \beta_{i}^{X} \times P_{\mathrm{i}}$ & 1 & $\begin{array}{l}\text { Indice geral de } \\
\text { precos }\end{array}$ \\
\hline \multicolumn{3}{|l|}{ GRUPO EQUILÍBRIO } \\
\hline $40-E T T=\Sigma_{\mathrm{i}} P_{\mathrm{i}}^{C} \times E S T_{\mathrm{i}}$ & 1 & Estoque total \\
\hline $4 I-I T=S_{\mathrm{M}}+S_{\mathrm{E}}+S_{\mathrm{G}}+e B C-E T T$ & 1 & $\begin{array}{l}\text { Financiamento } \\
\text { do investimento - } \\
\text { Neoclássico }\end{array}$ \\
\hline $42-Q_{\mathrm{i}}=C_{\mathrm{i}}+D I_{\mathrm{i}}+I N V_{\mathrm{i}}+E S T_{\mathrm{i}}$ & $\mathbf{i}$ & $\begin{array}{l}\text { Absorçallo } \\
\text { doméstica }\end{array}$ \\
\hline $43-L^{S}=\Sigma_{i} L_{\mathrm{i}}^{D}$ & 1 & Pleno emprego \\
\hline $\begin{array}{l}44-L E O N=Q_{\mathrm{SAD}}-C_{\mathrm{SAD}}-D I_{\mathrm{SAD}}-I N V_{\mathrm{SAD}}- \\
E S T_{\mathrm{SAD}}\end{array}$ & 1 & $\begin{array}{l}\text { Controle da } \\
\text { identidade de } \\
\text { Walras }\end{array}$ \\
\hline
\end{tabular}


ANEXO C - Estrutura da matriz de contabilidade do modelo

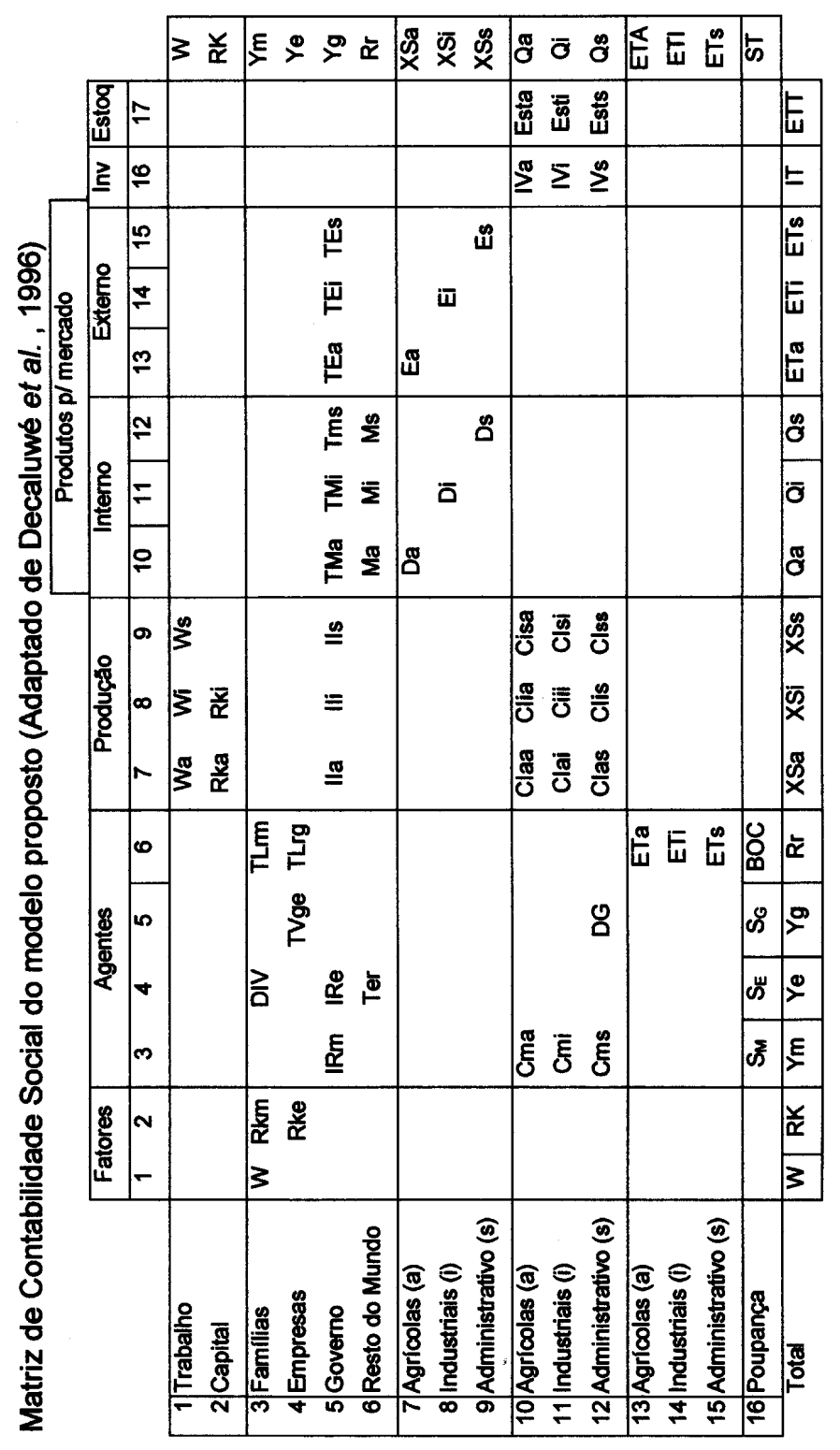




\section{Legenda}

$\mathrm{i}=1 \ldots \mathrm{n}$ (setores considerados)

$1=(\mathrm{M}, \mathrm{E}, \mathrm{G}, \mathrm{R})$ (agentes econômicos (M-famílias, E-empresas, G-governo, R-resto do mundo)

\section{Valor adicionado}

Wi - salário pago pela atividade $\mathrm{i}$

W - salário total pago às famílias

$\mathrm{RKi}$ - remuneração do capital por atividade $\mathrm{i}$

RKl - remuneração do capital paga aos agentes (famílias e empresas)

RK - remuneração total do capital

\section{Renda}

Yl - renda total dos agentes

$\mathrm{Rr} \quad$ - renda do resto do mundo

DIV - total de dividendos recebidos pelas famílias

S1 - poupança total por agente

ST - poupança total

\section{Impostos}

IDl - imposto de renda pago pelas famílias e empresas

TMi - impostos de importação do produto i

TEi - impostos de exportação do produto $\mathrm{i}$

IIi - impostos indiretos sobre o produto $\mathrm{i}$

\section{Relação com resto do mundo}

Trm - transferência líquidas do resto do mundo para as famílias (moeda local)

Tge - transferências líquidas do resto do mundo para as empresas (moeda local)

Trg - transferências do resto do mundo para o governo (moeda local)

Tge - transferências líquidas do governo para as empresas

Ter - transferências das empresas para o resto do mundo

$\mathrm{Mi}$ - importação do produto i

BOC - balanço de transações correntes (poupança do resto do mundo)

\section{Produção}

Clij - consumo intermediário da atividade $\mathrm{i}$ com o produto $\mathrm{j}$

VDi - produção do produto i oferecida ao mercado doméstico

VXis - produção total da atividade $\mathrm{i}$

\section{Demanda final}

Di - demanda das famílias pelo produto i

Ivi - investimento por produto $\mathrm{i}$

Esti - estoque por produto $\mathrm{i}$

IT - investimento total

ETT - estoque total

VXid - demanda total do produto $\mathrm{i}$ 


\section{ANEXO D - Valores dos parâmetros do modelo, obtidos a partir da calibração da matriz de conatabilidade social:}

$\boldsymbol{a}_{\boldsymbol{n}}$ - Coeficiente de escala do valor adicionado

$\begin{array}{lllllllll}\text { CAF } & 1.520, & \text { CAN } & 1.885, & \text { ARR } & 1.514, & \text { SOJ } 1.322, & \text { ALG } 1.517 \\ \text { MIL } & 1.493, & \text { BOV } & 1.166, & \text { LEI } 1.708, & \text { AOU } 1.378, & \text { EXT } 1.848 \\ \text { SID } & 1.932, & \text { MAQ } & 1.931, & \text { MET } & 1.805, & \text { AUT } 1.909, & \text { MAD } 1.999 \\ \text { QUI } & 1.622, & \text { ADU } & 1.973, & \text { OQU } & 1.973, & \text { TEX } 1.986, & \text { ICAF } 1.699 \\ \text { BEN } 1.884, & \text { ABT } 1.922, & \text { LAC } 1.770, & \text { ACU } 1.996, & \text { OLE } 1.620 \\ \text { ALI } 1.965, & \text { DIV } 1.851, & \text { SIU } 1.997, & \text { CIV } 1.667, & \text { MAR } 1.895 \\ \text { SER } 1.976 & & & & & & & \end{array}$

$\boldsymbol{\alpha}_{n}$ - Participação do salário no valor adicionado

\begin{tabular}{|c|c|c|c|c|c|c|c|c|c|}
\hline $\mathrm{CAF}$ & 0.148, & CAN & 0.330 , & ARR & 0.146 & SOJ & 0.080, & ALG & 0.147 \\
\hline MIL & 0.138, & $\mathrm{BOV}$ & 0.035, & LEI & 0.227 & $\mathrm{AOU}$ & 0.098, & EXT & 0.304 \\
\hline SID & 0.369 , & MAQ & 0.368 & $\mathrm{MET}$ & 0.277 , & AUT & 0.349 , & MAD & 0.515 \\
\hline QUI & 0.188 & $\mathrm{ADU}$ & 0.418 & OQU & 0.418 & TEX & 0.560 & ICAF & 0.223 \\
\hline BEN & 0.329 , & $\mathrm{ABT}$ & 0.360 & LAC & 0.258 & $\mathrm{ACU}$ & 0.531, & OLE & 0.187 \\
\hline ALI & 0.406, & DIV & 0.306 & SIU & 0.471 , & CIV & 0.208, & MAR & 0.663 \\
\hline $\mathrm{ER}$ & 0.577 & & & & & & & & \\
\hline
\end{tabular}

$\boldsymbol{a}_{i j}$ - Coeficiente técnico do consumo intermediário

Apresentado na Tabela 10

$\boldsymbol{\lambda}$ - Parcela da receita do capital destina às famílias

$\begin{array}{lll}\text { PARAMETER LAMBDA } & =0.500\end{array}$

$\boldsymbol{t} \boldsymbol{d} \boldsymbol{v}$ - Taxa de repasse de dividendos às famílias

$\begin{array}{lll}\text { PARAMETER TDV } & =0.250\end{array}$

pms - Propensão marginal a poupar

$\begin{array}{ll}\text { PARAMETER PMS } & =.109\end{array}$

ty - Imposto de renda - famílias

$\begin{array}{lll}\text { PARAMETER TY } & =0.043\end{array}$

tk - Imposto de renda - empresas

$\begin{array}{lll}\text { PARAMETER TK } & =0.071\end{array}$

$\boldsymbol{t} \boldsymbol{x}_{\mathrm{i}}$ - Imposto indireto 


$\begin{array}{lrllllll}\text { CAF } & 0.006, & \text { CAN } & 0.001, & \text { ARR } & 0.001, & \text { SOJ } & 0.025 \\ \text { MIL } & 3.634219 E-4, & \text { BOV } & 0.005, & \text { LEI } & 0.040, & \text { AOU } & 0.012 \\ \text { EXT } & 0.059, & \text { SID } & 0.104, & \text { MAQ } & 0.147, & \text { MET } & 0.214 \\ \text { AUT } & 0.197, & \text { MAD } & 0.139, & \text { QUI } & 0.131, & \text { ADU } & 0.034 \\ \text { OQU } & 0.113, & \text { TEX } & 0.168, & \text { ICAF } & 0.091, & \text { BEN } & 0.261 \\ \text { ABT } & 0.160, & \text { LAC } & 0.175, & \text { ACU } & 0.145, & \text { OLE } & 0.081 \\ \text { ALI } & 0.277, & \text { DIV } & 0.297, & \text { SIU } & 0.172, & \text { CIV } & 0.036 \\ \text { MAR } & 0.043, & \text { SER } & 0.065 & & & & \end{array}$

$\boldsymbol{t m}_{\boldsymbol{n}}$ - Imposto sobre importação

$\begin{array}{lllllllr}\text { CAF } & 0.108, & \text { CAN } & 0.014, & \text { ARR } & 0.027, & \text { SOJ } & 6.016354 E-5 \\ \text { ALG } & 0.030, & \text { MIL } & 0.006, & \text { BOV } & 0.002, & \text { LEI } & 0.078 \\ \text { AOU } & 0.031, & \text { EXT } & 0.081, & \text { SID } & 0.067, & \text { MAQ } & 0.079 \\ \text { MET } & 0.075, & \text { AUT } & 0.244, & \text { MAD } & 0.033, & \text { QUI } & 0.066 \\ \text { ADU } & 0.011, & \text { OQU } & 0.084, & \text { TEX } & 0.114, & \text { ICAF } & 0.069 \\ \text { BEN } & 0.041, & \text { ABT } & 0.016, & \text { LAC } & 0.126, & \text { ACU } & 0.017 \\ \text { OLE } & 0.022, & \text { ALI } & 0.076, & \text { DIV } & 0.088, & \text { SIU } & 0.006 \\ \text { MAR } & 0.006, & \text { SER } & 0.001 & & & & \end{array}$

$\boldsymbol{t} \boldsymbol{e}_{\boldsymbol{n}}$ - Imposto sobre exportação
( ALL
0.0001

$\boldsymbol{\beta}_{i}^{c}$ - Participação do bem i no consumo famílias

$\begin{array}{lllrlrrr}\text { CAF } & 0.001, & \text { CAN } & 1.293948 E-4, & \text { ARR } & 1.027443 \mathrm{E}-4, & \text { MIL } & 2.148256 \mathrm{E}-4 \\ \text { BOV } & 0.002, & \text { LEI } & 0.008, & \text { AOU } & 0.053, & \text { EXT } & 2.017891 \mathrm{E}-4 \\ \text { SID } & 0.006, & \text { MAQ } & 0.002, & \text { MET } & 0.038, & \text { AUT } & 0.046 \\ \text { MAD } & 0.021, & \text { QUI } & 0.046, & \text { ADU } & 3.248313 \mathrm{E}-5, & \text { OQU } & 0.002 \\ \text { TEX } & 0.046, & \text { ICAF } & 0.005, & \text { BEN } & 0.037, & \text { ABT } & 0.033 \\ \text { LAC } & 0.016, & \text { ACU } & 0.004, & \text { OLE } & 0.008, & \text { ALI } & 0.049 \\ \text { DIV } & 0.014, & \text { SIU } & 0.041, & \text { MAR } & 0.158, & \text { SER } & 0.356 \\ \text { SAD } & 0.006 & & & & & & \end{array}$

\section{$\boldsymbol{\beta}_{i}^{g}$ - Participação do bem i no consumo governo}

SAD 1.000

$\boldsymbol{\beta}_{i}^{I}$ - Participação do bem i no investimento total

$\begin{array}{rrrlrrr}\text { AOU } & 0.023, & \text { EXT } 1.233347 \mathrm{E}-4, & \text { SID } & 0.007, & \text { MAQ } & 0.113 \\ \text { MET } & 0.086, & \text { AUT } & 0.083, & \text { MAD } & 0.012, & \text { QUI } 6.946779 \mathrm{E}-4 \\ \text { OQU } & 1.652064 \mathrm{E}-8, & \text { TEX 2.113962E-4, } & \text { BEN 3.352990E-5, } & \text { ABT } 1.022041 \mathrm{E}-4 \\ \text { ALI 3.352990E-5, } & \text { DIV } & 0.009, & \text { SIU 4.239151E-4, } & \text { CIV } & 0.623 \\ \text { MAR } & 0.030, & \text { SER } & 0.011, & \text { SAD } & 0.003 & \end{array}$

$\boldsymbol{\beta}_{i}^{E}$ - Participação do bem i no estoque total

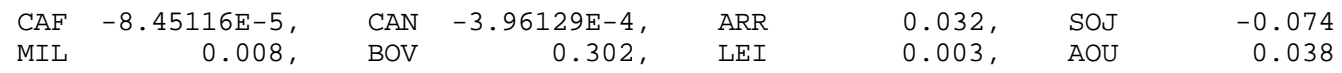




$\begin{array}{rrlllrlr}\text { EXT } & 0.009, & \text { SID } & 0.075, & \text { MAQ } & -0.057, & \text { MET } & 0.074 \\ \text { AUT } & 0.058, & \text { MAD } & 0.012, & \text { QUI } & 0.245, & \text { ADU } & -0.006 \\ \text { OQU } & 0.018, & \text { TEX } & 0.051, & \text { ICAF }-3.67091 E-4, & \text { BEN } & 0.014 \\ \text { ABT } & 0.048, & \text { LAC } & 0.010, & \text { ACU } & -0.013, & \text { OLE } & 0.011 \\ \text { ALI } & 0.026, & \text { DIV } & 0.046, & \text { SIU } 3.444777 E-4, & \text { MAR } & 0.067 \\ \text { SER 2.236058E-4, } & \text { SAD } & 0.002 & & & & \end{array}$

\section{$\boldsymbol{\beta}_{i}^{X}$ - Participação do bem i na produção total}

$\begin{array}{lrllllll}\text { CAF } & 0.004, & \text { CAN } & 0.004, & \text { ARR } & 0.002, & \text { SOJ } & 0.004 \\ \text { ALG } & 4.215820 E-4, & \text { MIL } & 0.004, & \text { BOV } & 0.010, & \text { LEI } & 0.007 \\ \text { AOU } & 0.044, & \text { EXT } & 0.009, & \text { SID } & 0.045, & \text { MAQ } & 0.019 \\ \text { MET } & 0.024, & \text { AUT } & 0.033, & \text { MAD } & 0.028, & \text { QUI } & 0.065 \\ \text { ADU } & 0.004, & \text { OQU } & 0.006, & \text { TEX } & 0.028, & \text { ICAF } & 0.005 \\ \text { BEN } & 0.015, & \text { ABT } & 0.015, & \text { LAC } & 0.007, & \text { ACU } & 0.005 \\ \text { OLE } & 0.010, & \text { ALI } & 0.021, & \text { DIV } & 0.025, & \text { SIU } & 0.034 \\ \text { CIV } & 0.081, & \text { MAR } & 0.109, & \text { SER } & 0.207, & \text { SAD } & 0.128\end{array}$

\section{$\boldsymbol{b}_{\boldsymbol{n}}{ }^{T}$ - Parâmetro de dimensão da função CET}

$\begin{array}{lrlrlrlr}\text { CAF } & 3.799, & \text { CAN } & 10.478, & \text { ARR } & 186.399, & \text { SOJ } & 2.815 \\ \text { ALG } & 722.660, & \text { MIL } & 37.140, & \text { BOV } & 18.959, & \text { LEI } & 78.384 \\ \text { AOU } & 10.242, & \text { EXT } & 2.232, & \text { SID } & 3.058, & \text { MAQ } & 2.442 \\ \text { MET } & 2.478, & \text { AUT } & 2.279, & \text { MAD } & 2.758, & \text { QUI } & 2.954 \\ \text { ADU } & 13.589, & \text { OQU } & 2.567, & \text { TEX } & 2.444, & \text { ICAF } & 2.090 \\ \text { BEN } & 2.760, & \text { ABT } & 3.994, & \text { LAC } & 26.013, & \text { ACU } & 2.073 \\ \text { OLE } & 2.267, & \text { ALI } & 4.857, & \text { DIV } & 2.651, & \text { SIU } & 27.227 \\ \text { CIV } & 1398.669, & \text { MAR } & 3.766, & \text { SER } & 7.283 & & \end{array}$

\section{$\boldsymbol{\delta}_{\mathrm{n}}{ }^{T}$ - Parâmetro de proporção da função CET}

$\begin{array}{lllllllll}\text { CAF } & 0.934, & \text { CAN } & 0.993, & \text { ARR } & 1.000, & \text { SOJ } 0.864, & \text { ALG } 1.000 \\ \text { MIL } & 1.000, & \text { BOV } & 0.998, & \text { LEI } & 1.000, & \text { AOU } 0.993, & \text { EXT } 0.698 \\ \text { SID } & 0.902, & \text { MAQ } & 0.716, & \text { MET } & 0.724, & \text { AUT } 0.678, & \text { MAD } 0.816 \\ \text { QUI } & 0.792, & \text { ADU } & 0.997, & \text { OQU } & 0.739, & \text { TEX } & 0.725, & \text { ICAF } 0.655 \\ \text { BEN } & 0.858, & \text { ABT } & 0.941, & \text { LAC } & 0.999, & \text { ACU } & 0.645, & \text { OLE } 0.759 \\ \text { ALI } & 0.962, & \text { DIV } & 0.763, & \text { SIU } & 0.999, & \text { CIV } & 1.000, & \text { MAR } 0.900 \\ \text { SER } & 0.970 & & & & & & & \end{array}$

\section{$\boldsymbol{\rho}_{n}{ }^{T}$-Expoente da função CET}

\begin{tabular}{|c|c|c|c|c|c|c|c|c|c|}
\hline $\mathrm{CAF}$ & 2.111, & CAN & 2.111, & ARR & 2.111 & SOJ & 2.111, & ALG & 2.111 \\
\hline MIL & 2.111 & $\mathrm{BOV}$ & 2.111 & LEI & 2.111 & $\mathrm{AOU}$ & 2.111 & EXT & 1.769 \\
\hline SID & 2.250 & MAQ & 1.476, & MET & 1.476 & AUT & 1.476, & MAD & 1.769 \\
\hline QUI & 1.476, & $A D U$ & 2.250 & OQU & 1.476, & TEX & 1.526 & ICAF & 2.111 \\
\hline BEN & 2.111 & $\mathrm{ABT}$ & 2.111, & LAC & 2.111, & $\mathrm{ACU}$ & 2.111, & OLE & 2.250 \\
\hline ALI & 2.111 & DIV & 1.526, & SIU & 2.111 & CIV & 2.111, & MAR & 769 \\
\hline \multicolumn{10}{|c|}{$\boldsymbol{b}_{\boldsymbol{n}}{ }^{S}$ - Parâmetro de dimensão da função Armington } \\
\hline $\mathrm{CAF}$ & 1.007, & CAN & 1.002 & ARR & 1.203, & SOJ & 1.476, & ALG & 1.017 \\
\hline MIL & 1.376, & $\mathrm{BOV}$ & 1.174, & LEI & 1.094, & $\mathrm{AOU}$ & 1.347, & EXT & 1.988 \\
\hline SID & 1.616, & MAQ & 2.050 & $\mathrm{MET}$ & 2.222 & AUT & 2.166 & MAD & 1.517 \\
\hline QUI & 1.733 & $\mathrm{ADU}$ & 1.778, & OQU & 1.770, & TEX & 1.778 & ICAF & 1.154 \\
\hline BEN & 1.598, & $\mathrm{ABT}$ & 1.323, & LAC & 1.601, & $\mathrm{ACU}$ & 1.276 & OLE & 1.484 \\
\hline ALI & 1.716, & DIV & 2.044, & SIU & 1.323, & CIV & 1.036, & MAR & 1.200 \\
\hline P & 1.203 & & & & & & & & \\
\hline
\end{tabular}




\section{$\boldsymbol{\delta}_{n}{ }^{S}$ - Parâmetro de proporção da função Armington}

$\begin{array}{lrlrllll}\text { CAF } & 1.404068 E-5, & \text { CAN } & 2.669540 E-5, & \text { ARR } & 0.068, & \text { SOJ } & 0.186 \\ \text { ALG } & 0.009, & \text { MIL } & 0.163, & \text { BOV } & 0.069, & \text { LEI } & 0.007 \\ \text { AOU } & 0.131, & \text { EXT } & 0.280, & \text { SID } & 0.191, & \text { MAQ } & 0.325 \\ \text { MET } & 0.381, & \text { AUT } & 0.313, & \text { MAD } & 0.122, & \text { QUI } & 0.190 \\ \text { ADU } & 0.300, & \text { OQU } & 0.243, & \text { TEX } & 0.204, & \text { ICAF } & 0.005 \\ \text { BEN } & 0.080, & \text { ABT } & 0.044, & \text { LAC } & 0.127, & \text { ACU } & 0.016 \\ \text { OLE } & 0.140, & \text { ALI } & 0.141, & \text { DIV } & 0.263, & \text { SIU } & 0.032 \\ \text { CIV } & 2.244395 E-7, & \text { MAR } & 0.036, & \text { SER } & 0.031 & & \end{array}$

\section{$\boldsymbol{\rho}_{\boldsymbol{n}}{ }^{S}$ - Expoente da função Armington}

\begin{tabular}{|c|c|c|c|c|c|c|c|c|c|}
\hline $\mathrm{CAF}$ & 0.111, & CAN & 0.111, & ARR & -0.286 & SOJ & -0.500, & ALG & -0.500 \\
\hline MIL & -0.500, & BOV & -0.412 & LEI & 0.111, & $\mathrm{AOU}$ & -0.412 & $\mathrm{EXT}$ & 0.250 \\
\hline SID & -0.500 & MAQ & -0.474 & MET & -0.630 & AUT & -0.474 & MAD & -0.375 \\
\hline QUI & -0.286 & $\mathrm{ADU}$ & -0.500 & OQU & -0.500, & TEX & -0.448 & ICAF & -0.286 \\
\hline BEN & -0.286 & $\mathrm{ABT}$ & -0.286 & LAC & -0.286 & $\mathrm{ACU}$ & -0.286 & OLE & -0.444 \\
\hline ALI & -0.444, & DIV & -0.615 & SIU & -0.091 , & CIV & 0.111, & MAR & -0.091 \\
\hline SER & -0.091 & & & & & & & & \\
\hline
\end{tabular}

$i \boldsymbol{o}_{i}$ - Participação do consumo intermediário na produção

$\begin{array}{llllllllll}\text { CAF } & 0.470, & \text { CAN } & 0.466, & \text { ARR } & 0.322, & \text { SOJ } 0.675, & \text { ALG } & 0.407 \\ \text { MIL } & 0.216, & \text { BOV } & 0.195, & \text { LEI } & 0.589, & \text { AOU } & 0.328, & \text { EXT } & 0.530 \\ \text { SID } & 0.715, & \text { MAQ } & 0.456, & \text { MET } & 0.647, & \text { AUT } & 0.699, & \text { MAD } & 0.645 \\ \text { QUI } & 0.603, & \text { ADU } & 0.621, & \text { OQU } & 0.774, & \text { TEX } & 0.693, & \text { ICAF } & 0.760 \\ \text { BEN } & 0.787, & \text { ABT } & 0.827, & \text { LAC } & 0.824, & \text { ACU } & 0.823, & \text { OLE } & 0.874 \\ \text { ALI } & 0.735, & \text { DIV } & 0.587, & \text { SIU } & 0.391, & \text { CIV } & 0.437, & \text { MAR } & 0.436 \\ \text { SER } & 0.419, & \text { SAD } & 0.338 & & & & & & \end{array}$

\section{$v_{n}$ - Participação do valor adicionado na produção}

$\begin{array}{llllllllll}\text { CAF } & 0.530, & \text { CAN } & 0.534, & \text { ARR } & 0.678, & \text { SOJ } & 0.325, & \text { ALG } & 0.593 \\ \text { MIL } & 0.784, & \text { BOV } & 0.805, & \text { LEI } & 0.411, & \text { AOU } & 0.672, & \text { EXT } & 0.470 \\ \text { SID } & 0.285, & \text { MAQ } & 0.544, & \text { MET } & 0.353, & \text { AUT } & 0.301, & \text { MAD } & 0.355 \\ \text { QUI } & 0.397, & \text { ADU } & 0.379, & \text { OQU } & 0.226, & \text { TEX } & 0.307, & \text { ICAF } & 0.240 \\ \text { BEN } & 0.213, & \text { ABT } & 0.173, & \text { LAC } & 0.176, & \text { ACU } & 0.177, & \text { OLE } & 0.126 \\ \text { ALI } & 0.265, & \text { DIV } & 0.413, & \text { SIU } & 0.609, & \text { CIV } & 0.563, & \text { MAR } & 0.564 \\ \text { SER } & 0.581, & \text { SAD } & 0.662 & & & & & & \end{array}$




\title{
ANEXO E - Programa de calibração contendo os dados da SAM
}

\author{
\$TITLE CAL 3 : MODELO VERSAO JULHO DE 2001 \\ \$STITLE ECONOMIA BRASILEIRA
}

*ROTINA DE CALIBRAÇÃo

*DEFINIÇÃO DOS CONJUNTOS DO MODELO

$\begin{array}{lll}\text { SET I CAF } & \text { CAFE } \\ \text { CAN } & \text { CANA } \\ \text { ARR } & \text { ARROZ } \\ \text { SOJ } & \text { SOJA } \\ \text { ALG } & \text { ALGODAO } \\ \text { MIL } & \text { MILHO } \\ \text { BOV } & \text { BOVINO E SUINOS } \\ \text { LEI } & \text { LEITE NATURAL } \\ \text { AOU } & \text { OUTROS AGROPECUARIA } \\ \text { EXT } & \text { EXTRATIVA } \\ \text { SID } & \text { SIDERURGIA } \\ \text { MAQ } & \text { MAQUINAS E TRATORES } \\ \text { MET } & \text { MATERIAL ELETRICO } \\ \text { AUT } & \text { AUTOMOVEIS } \\ \text { MAD } & \text { MADEIRA E PAPEL } \\ \text { QUI } & \text { QUIMICOS } \\ \text { ADU } & \text { ADUBOS } \\ \text { OQU } & \text { OUTROS QUIMICOS } \\ \text { TEX } & \text { IND. TEXTIL } \\ \text { ICAF } & \text { INDUSTRIA DO CAFE } \\ \text { BEN } & \text { BENEF. PROD. VEGETAL } \\ \text { ABT } & \text { ABATE DE ANIMAIS } \\ \text { LAC } & \text { LATICINIOS } \\ \text { ACU } & \text { ACUCAR } \\ \text { OLE } & \text { IND. OLEOS VEGETAIS } \\ \text { ALI } & \text { OUTROS PROD. ALIMENTICIOS } \\ \text { DIV } & \text { IND. DIVERSOS } \\ \text { SIU } & \text { SIUP } \\ \text { CIV } & \text { CONSTRUCAO CIVIL } \\ \text { MAR } & \text { MARGENS DE COMERCIO E TRABSPORTE } \\ \text { SER } & \text { SERVICOS } \\ \text { SAD } & \text { SERV ADMINISTRATIFS / } \\ & \text { CAF } & \text { CAFE } \\ \text { CAN } & \text { CANA } \\ & \\ \text { N (I) } & \end{array}$




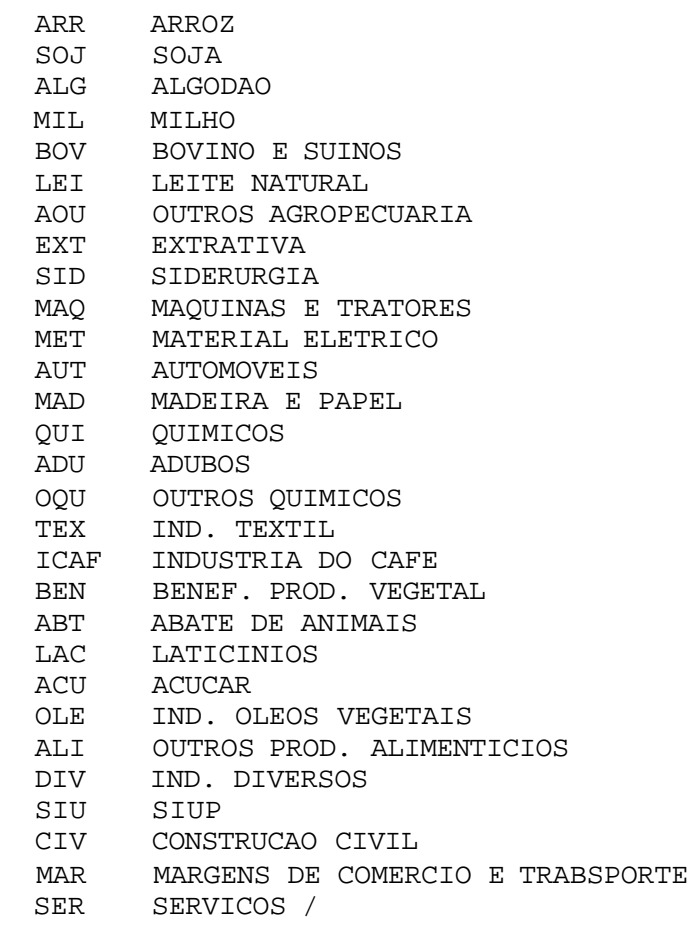

$\mathrm{AD}$ (I)

/SAD SERV ADMINISTRATIFS/

ALIAS $(I, J)$

*DEFINIÇÃO DOS PARÂMETROS E VARIÁVEIS

*PARÂMETROS

\begin{tabular}{|c|c|c|c|c|c|c|c|c|}
\hline PARAMETER & $\begin{array}{l}\text { a (N) } \\
\text { beta_g(I) } \\
\text { tk } \\
\text { rho_s (I) }\end{array}$ & $\begin{array}{r}\text { alpha (N) } \\
\text { beta_i (I) } \\
\text { tm (I) } \\
\text { delta_s (I) }\end{array}$ & 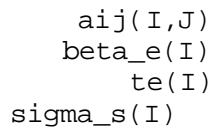 & 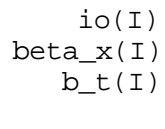 & $\begin{array}{c}\mathrm{v}(\mathrm{I}) \\
\text { lambda } \\
\text { rho_t (I) }\end{array}$ & $\begin{array}{r}u(A D) \\
t d v \\
d e l t a \_t(I)\end{array}$ & $\begin{array}{c}\text { pms } \\
\text { ty } \\
\text { sigma_t (I) }\end{array}$ & $\begin{array}{l}\text { beta_c (I) } \\
\operatorname{tx}(I) \\
\text { b_s }(I)\end{array}$ \\
\hline
\end{tabular}

*VARIÁVEIS

*PRIX 


\begin{tabular}{|c|c|c|c|c|c|c|c|}
\hline $\begin{array}{l}\text { WO } \\
\text { PMO (I) }\end{array}$ & $\begin{array}{r}\mathrm{RO}(\mathrm{N}) \\
\operatorname{PEO}(\mathrm{I})\end{array}$ & $\begin{array}{l}\text { PVAO (N) } \\
\text { PWMO (I) }\end{array}$ & $\begin{array}{r}P O(I) \\
\text { PWEO (I) }\end{array}$ & $\begin{array}{c}\mathrm{PDO}(\mathrm{N}) \\
\mathrm{EO}\end{array}$ & $\mathrm{PCO}(\mathrm{I})$ & & P INDEXO \\
\hline $\operatorname{VAO}(\mathrm{I})$ & & VSO (i) & $\mathrm{XSO}(\mathrm{I})$ & & & & \\
\hline $\mathrm{KO}(\mathrm{N})$ & LSO & & LDO (I) & & & & \\
\hline CTMO & & $\mathrm{CMO}(\mathrm{I})$ & CTGO & & $\mathrm{CGO}(\mathrm{I})$ & $\mathrm{CO}(\mathrm{I})$ & ITO \\
\hline $\operatorname{INVO}(I)$ & & ETTO & $\operatorname{ESTO}(I)$ & & $\mathrm{DIO}(\mathrm{I})$ & CIO (I) & $\operatorname{CIJO}(I, J)$ \\
\hline $\mathrm{VDO}(\mathrm{I})$ & & $\mathrm{DO}(\mathrm{N})$ & $\mathrm{VQO}(\mathrm{I})$ & & $\mathrm{QO}(\mathrm{I})$ & VMO (i) & $\mathrm{MO}(\mathrm{I})$ \\
\hline $\operatorname{VEO}(i)$ & & $\operatorname{EXO}(I)$ & & & & & \\
\hline YMO & & YDMO & RPO & & YEO & & YGO \\
\hline SMO & & SEO & $\mathrm{SGO}$ & & DIVO & & REIO \\
\hline TGEO & & TRGO & TRMO & & TERO & & TXYO \\
\hline TXKO & & TXSO (I) & TXMO (I) & & $\operatorname{TXEO}(I)$ & & $\mathrm{BCO}$ \\
\hline
\end{tabular}

*DADOS DA SAM

TABLE CIJO(I,J) CONSUMO INTERMEDIÁRIO (VALOR)

$\begin{array}{lll} & \text { CAF } & \text { CAN } \\ \text { CAF } & 1273156.37900000 & 0.00000000 \\ \text { CAN } & 5.56069687 & 251022.87600000 \\ \text { ARR } & 0.00000000 & 0.00000000 \\ \text { SOJ } & 0.00000000 & 0.00000000 \\ \text { ALG } & 0.00000000 & 0.00000000 \\ \text { MIL } & 0.00000000 & 0.00000000 \\ \text { BOV } & 0.00000000 & 0.00000000 \\ \text { LEI } & 0.00000000 & 0.00000000 \\ \text { AOU } & 99.29665900 & 256.96285000 \\ \text { EXT } & 11670.87970000 & 33427.60350000 \\ \text { SID } & 8104.64334000 & 22553.70670000 \\ \text { MAQ } & 9703.49599000 & 11801.39393000 \\ \text { MET } & 579.41329600 & 652.49482400 \\ \text { AUT } & 782.70723200 & 1043.88692000 \\ \text { MAD } & 4896.91683000 & 1973.38254000 \\ \text { QUI } & 101401.06320000 & 292400.26300000 \\ \text { ADU } & 274306.56300000 & 439228.77100000 \\ \text { OQU } & 93180.11500000 & 161104.62200000 \\ \text { TEX } & 13271.32893000 & 4692.20603000 \\ \text { ICAF } & 1.71999660 & 2.93770360\end{array}$

ARR
0.00000000
5.72873252
114161.52970000
0.00000000
0.00000000
0.00000000
0.00000000
0.00000000
67.08696200
7473.28590000
5381.46902000
10388.06522000
562.54348400
764.57259900
4113.59035000
121972.01300000
107782.16300000
78948.79600000
7039.40061000
1.12645810

SOJ

0.00000000

3.19551381

0.00000000

262997.40900000

0.00000000

0.00000000

0.00000000

0.00000000

233.50842900

25757.60680000

18627.41680000

35924.79700000

1593.64132400

2388.14629000

3208.54682000

356998.80200000

848471.02000000

452685.57200000

5754.28365000

2.53014560 


$\begin{array}{ll}\text { BEN } & 430.40424600 \\ \text { ABT } & 135.88769500 \\ \text { LAC } & 37.67881620 \\ \text { ACU } & 199.66894500 \\ \text { OLE } & 3734.60145000 \\ \text { ALI } & 18885.58690000 \\ \text { DIV } & 6921.08027000 \\ \text { SIU } & 18355.81312300 \\ \text { CIV } & 89.62793200 \\ \text { MAR } & 103155.75973603 \\ \text { SER } & 66406.85496500 \\ \text { SAD } & 23979.74900000 \\ & \\ + & \text { MIL } \\ \text { CAF } & 0.00000000 \\ \text { CAN } & 7.26210111 \\ \text { ARR } & 0.0000000 \\ \text { SOJ } & 0.0000000 \\ \text { ALG } & 0.0000000 \\ \text { MIL } & 27128.65401000 \\ \text { BOV } & 0.00000000 \\ \text { LEI } & 0.00000000 \\ \text { AOU } & 90.26592900 \\ \text { EXT } & 9422.55380000 \\ \text { SID } & 6836.39907000 \\ \text { MAQ } & 14094.21384000 \\ \text { MET } & 699.05114900 \\ \text { AUT } & 988.84909000 \\ \text { MAD } & 5029.16323000 \\ \text { QUI } & 125986.65500000 \\ \text { ADU } & 253022.59200000 \\ \text { OQU } & 120220.49500000 \\ \text { TEX } & 6334.50904000 \\ \text { ICAF } & 2.21125230 \\ \text { BEN } & 531.02084000 \\ \text { ABT } & 141.29503500 \\ \text { LAC } & 47.39126070 \\ \text { ACU } & 251.77750900 \\ \text { OLE } & 6577.55603000 \\ \text { ALI } & 19468.45390000 \\ \text { DIV } & 5843.77296000 \\ \text { SIU } & 15632.30971440 \\ \text { CIV } & 175.54216000 \\ \text { MAR } & 128178.59941679 \\ \text { SER } & 55660.00330200 \\ \text { SAD } & 18728.23050000 \\ & \end{array}$

625.58817700
128.32089100
50.92326980
156.26844950
4892.61884000
17694.69730000
18625.31340000
15901.61793200
37.12656400
474788.83878190
219149.68744580
48923.22140000

B0V
0.00000000
1.75698554
0.00000000
0.00000000
0.00000000
752820.14900000
572202.98500000
0.00000000
152.22438200
8601.50060000
5822.35105000
3536.39954000
260.59658200
339.79862200
1038.54489000
33198.90180000
22569.98200000
40633.73290000
1321.81800800
4.91916020
4083.64433000
3227.77572000
47.32768160
73.14519510
141993.97400000
463831.91900000
4720.01763000
10758.11634970
41.32868700
125209.03370546
13705.97279840
2805.27617000

273.67751000

29.74496130

29.48088680

203.36233000

2142.16446000

3751.21515000

4480.66271000

17103.42262950

122.98069000

87102.60198818

56138.52915200

8826.99760000

LEI

0.00000000

27.99029280

0.00000000

0.00000000

0.00000000

36171.53868000

0.00000000

1458659.00000000

505.01305400

47651.74080000

34094.85790000

61423.94900000

4383.07917000

15706.17890000

633290.72000000

238974.11000000

561835.33500000

14514.61609000

4.44469350

5645.00522000

3255.72082000

487.67606400

992.91144200

127495.87500000

460290.21500000

28314.44570000

84822.22844500

607.27355000

407656.07824420

241635.24911100

59469.13010000
1557.79553000

187.04316800

124.31277700

124.23425500

10322.11485000

26488.18730000

16691.54270000

17642.98184580

73.24375200

383479.98109649

107898.56913400

54897.56330000

$\mathrm{AOU}$

0.00000000

75.48993921

0.00000000

0.00000000

0.00000000

444600.83600000

0.00000000

0.00000000

6969981.37587245

97663.09191500

68421.89800830

93176.31555960

5584.95951724

7469.41667870

105355.77672240

978850.52035000

1085516.68028000

835810.65808000

166083.28920470

23.29473537

27039.13305190

41463.43259714

444.21710837

2614.34988478

247080.81836480

2115468.91205400

57734.79687800

160283.77743488

1562.07943194

481548.26608200

42704.33548248

193079.52241100
135.03976200

7.51331122

11.34338770

37.84765370

529.72950300

1011.06421300

1406.93161000

1908.97671430

29121.06160867

17467.9356327

EXT

0.00000000

0.00000000

0.00000000

0.00000000

0.00000000

0.00000000

0.00000000

0.00000000

9649.03500000

560065.24000000

484674.71300000

622317.36200000

48484.98510000

25639.09550000

110993.93810000

452432.79000000

7.61670634

199155.12500000

24191.10040000

98.66889500

1011.89865300

267.69516400

286.53582630

500.30209000

838.03994700

8171.99429000

225421.25000000

405331.01339900

768288.51033006

1102494.7383300

116753.56030000 


\section{SID}

0.00000000

0.04928263

0.00000000

0.00000000

0.00000000

0.00000000

0.00000000

780731.62100000

2106037.49000000

0818113.66000000

547929.99600000

235074.33900000

110467.57270000

432687.54200000

1894472.40100000

10.05565429

294965.33100000

5403.06350000

214.69924000

3489.47030000

3868.42376000

628.76412210

1824.14812518

1350.14827300

1191758.43000000

1611409.01296000

80503.08800000

2426871.93289489

1277273.38017500

136262.72310000

QUI

81.84145530

162260.58423990

0.00000000

0.00000000

0.00000000

.00000000

2424.68246557

3771.91381355

96147.20882731

293982.0804986

672301.90662645

1186984.45103177
MAQ

0.00000000

0.01302625

0.00000000

0.00000000

0.00000000

0.00000000

0.00000000

138.82566600

490.71761200

3981931.60000000

1167001.42800000

760367.42900000

430603.98360000

196024.23700000

553512.30300000

8.25681313

25014.77340000

53185.6541000

167.79188000

810.39205000

349.46175400

460.62257473

481.95578181

512.77159530

8795.42972000

409789.96300000

430090.22406100

53863.59300000

899609.52957811

561410.56669600

64436.41580000

\section{ADU}

0.00000000

115.71156690

0.00000000

0.00000000

0.00000000

0.00000000

55.66906503

365.84407445

32431.84167269

44010.74150134

114237.25367355
34989.56196823
MET

0.00000000

0.01031804

0.00000000

0.00000000

0.00000000

0.00000000

0.00000000

1034.42404000

52633.62040000

3407237.28000000

1096895.78700000

6299288.24000000

86287.83970000

624860.69100000

1473878.15100000

5.99488327

34762.58840000

33495.37370000

200.38395000

976.45756100

381.96613310

544.31637592

405.69614862

667.51658700

6758.73528000

618339.58600000

352109.45743800

46069.02300000

1543069.84789027

992749.68704400

130262.39640000

\section{$\mathrm{OQU}$}

0.00000000

166.88579100

0.00000000

0.00000000

0.00000000

0.00000000

79.81233050

524.50796500

47920.29440000

63627.14100000

187310.42300000

50164.27900000
AUT

0.00000000

0.10339649

0.00000000

0.00000000

0.00000000

0.00000000

0.00000000

0.00000000

440.78129900

1196.01597300

129037.11000000

1569969.63000000

314901.62900000

10443125.93200000

391006.48700000

1326411.72100000

6.32982212

35706.30710000

80109.74200000

211.49420000

1081.65566600

394.10095020

644.53783328

530.35790990

683.87982820

1514739.50100000

406902.08514500

59244.59200000

1750370.57565825

1063940.93001000

216731.34570000

\section{TEX}

0.00000000

0.02555201

0.00000000

0.00000000

440158.57000000

0.00000000

31310.43653000

0.00000000

394688.64400000

4749.88474000

159101.25000000

343833.46600000
MAD

0.00000000

0.14227638

0.00000000

0.00000000

0.00000000

0.00000000

0.00000000

2253898.86000000

41406.90810000

547626.75500000

505225.39000000

45027.10110000

34026.95290000

7174260.38000000

2518958.54300000

11.83652870

266554.31100000

218766.02400000

494.27055700

45941.80660000

10676.84006000

1108.92080800

1188.40329150

17763.96100000

477690.33600000

919150.16788000

72598.85200000

2301845.87525755

1062153.28664000

979602.72300000

\section{ICAF}

2173380.78300000

0.00000000

0.00000000

0.00000000

0.00000000

0.00000000

0.00000000

0.00000000

12723.90260000

143.53721660

8323.23501000

7839.67951000 


\begin{tabular}{ll} 
MET & 107054.04026861 \\
AUT & 44159.97519298 \\
MAD & 868327.26483278 \\
QUI & 20249961.80193690 \\
ADU & 88897.29201933 \\
OQU & 666189.57724910 \\
TEX & 163805.08908161 \\
ICAF & 824.62536613 \\
BEN & 34426.85829380 \\
ABT & 34818.86190586 \\
LAC & 11040.63445884 \\
ACU & 429120.18798621 \\
OLE & 739210.75825499 \\
ALI & 31514.54061163 \\
DIV & 654720.74692508 \\
SIU & 1402594.92243211 \\
CIV & 132620.72555842 \\
MAR & 3579247.15824432 \\
SER & 1823992.81753544 \\
SAD & 334009.00193452 \\
& \\
+ & BEN \\
CAF & 18064.31200500 \\
CAN & 3277.65825000 \\
ARR & 1507278.3900000 \\
SOU & 69870.74450000 \\
ALG & 0.0000000 \\
MIL & 358048.56200000 \\
BOV & 419.13064800 \\
LEI & 15875.33056100 \\
AOU & 6736843.00856820 \\
EXT & 2940.04270000 \\
SID & 245270.20900000 \\
MAQ & 121408.65640000 \\
MET & 12024.84076000 \\
AUT & 7809.02456000 \\
MAD & 403340.13600000 \\
QUI & 350726.29200000 \\
ADU & 20.91693960 \\
OQU & 25096.00530000 \\
TEX & 80835.97350000 \\
ICAF & 2947.54329000 \\
BEN & 592384.27800000 \\
ABT & 32937.46760000 \\
LAC & 13606.41358000 \\
ACU & 105820.67860000 \\
OLE & 74563.22510000 \\
& \\
\hline
\end{tabular}

4931.09556139
2120.79346702
55717.03146722
145797.17566311
1481853.04768067
192.07250210
10227.82155839
21.81598687
130.81453320
950.19378814
642.76389316
3766.20428379
51.02720349
122.04972657
46932.44577492
43362.13616889
6110.39154158
217906.91687010
123607.59626956
89825.88196548

$A B T$
0.00000000
0.00000000
0.0000000
0.00000000
0.00000000
2351.30153000
6636364.20000000
0.0000000
2143101.57300000
6615.61430000
122241.90630000
87338.28160000
8107.8945000
5234.74756000
133326.75000000
273491.60800000
95.83498710
10204.29496000
31031.19730000
220.23582900
38017.01950000
1684286.42000000
5227.16027000
283.93604050
4643.20752000
7069.67536000
3040.56606000
81920.17060000
2696648.10200000
6.29891820
590651.95300000
14979.48273000
106.39905020
27656.99260000
1431.24930000
1238.16691000
5505.20102000
206089.28600000
12263.86796000
80463.16660000
62167.97560600
8760.42350000
350726.44763560
350726.44763560
28108.09880000

LAC

0.00000000

990.96854800

0.00000000

0.00000000

0.00000000

0.00000000

14279.30515000

3313631.51230000

8464.51894000

220.77421960

79144.15270000

34110.89460000

3300.04782000

2630.29364000

71009.33370000

186481.40800000

15.71548480

7622.62509000

4998.66278000

147.05850300

40998.05090000

195.98483300

1589416.24600000

31930.53030000

23880.10840000
33406.15430000

15927.51241000

399438.43600000

2603443.27100000

15.37586720

177656.12800000

12249527.21000000

323.72179900

8949.80989000

435167.42810000

2143.64673300

776.39319624

5944.05506000

17425.43430000

445345.46970000

510515.43450900

38033.55900000

1684395.24913813

755190.98170000

114391.82740000

ACU

0.00000000

1623442.02100000

0.00000000

0.00000000

0.00000000

0.00000000

0.00000000

0.00000000

7036.06462000

196.93292040

58714.97900000

300344.64300000

20849.63115000

8449.22176000

68706.09980000

144447.88580000

1.77004130

29084.97300000

200862.66400000

29.08748700

273.21555340

88.74775270

93.19933129

880832.45000000

231.52570870
467.52979600

35032.59480000

41569.94840000

0.56826212

1417.64239300

13791.41150000

1383866.18700000

3849.70013000

90.63417250

54.21770221

39.13329871

50.82826680

1709.73465000

20724.80800000

30569.26439100

3574.15540000

155068.78300714

74650.93349000

12304.44480000

OLE

0.00000000

0.00000000

1559.67937000

3905693.17000000

1313.12978000

6208.24494000

6593.58854000

0.00000000

495866.66400000

2679.50027000

279586.05200000

70338.76330000

6678.50029000

6484.65658000

106190.37070000

234205.44270000

3.01079225

30056.39810000

190739.94750000

718.62286000

217151.91200000

93113.10070000

956.57296900

270.00909700

2092232.92000000 


$\begin{array}{ll}\text { ALI } & 35964.45580000 \\ \text { DIV } & 155501.0050000 \\ \text { SIU } & 214007.23418400 \\ \text { CIV } & 18405.22600000 \\ \text { MAR } & 1440527.42514820 \\ \text { SER } & 397607.61028000 \\ \text { SAD } & 167558.23300000 \\ & \\ + & \text { ALI } \\ \text { CAF } & 2574.60527000 \\ \text { CAN } & 185547.32640000 \\ \text { ARR } & 4187.12098000 \\ \text { SOJ } & 174676.14400000 \\ \text { ALG } & 0.00000000 \\ \text { MIL } & 1138232.39000000 \\ \text { BOV } & 11928.65297000 \\ \text { LEI } & 40311.50640000 \\ \text { AOU } & 1758814.41900000 \\ \text { EXT } & 106749.43000000 \\ \text { SID } & 376880.95300000 \\ \text { MAQ } & 206171.5595000 \\ \text { MET } & 19162.16357000 \\ \text { AUT } & 13385.67358000 \\ \text { MAD } & 765953.33500000 \\ \text { QUI } & 921564.49400000 \\ \text { ADU } & 620.56627200 \\ \text { OQU } & 256143.44100000 \\ \text { TEX } & 44508.51490000 \\ \text { ICAF } & 7499.33422000 \\ \text { BEN } & 3065463.12000000 \\ \text { ABT } & 195431.3960000 \\ \text { LAC } & 148901.26820000 \\ \text { ACU } & 659741.03400000 \\ \text { OLE } & 1450609.98000000 \\ \text { ALI } & 1494279.81000000 \\ \text { DIV } & 417243.97000000 \\ \text { SIU } & 451979.76162800 \\ \text { CIV } & 32634.46100000 \\ \text { MAR } & 1941218.67187800 \\ \text { SER } & 810286.57167200 \\ \text { SAD } & 215780.34900000 \\ & \end{array}$

SER

$\begin{array}{ll}\text { CAF } & 87301.64664458 \\ \text { CAN } & 15551.60654006\end{array}$

ARR $\quad 2806.99731960$

SOJ $\quad 0.00000000$
96243.05400000 24853.67170000 200811.73861500 27799.33800000 1071028.19570240 396423.56294600 49393.30330000

0.06235745

0.00000000

0.00000000

0.00000000

0.00000000

427.10854700

0.00000000

410607.53500000

824053.17000000

807771.47200000

466541.61000000

116863.99600000

30894.54300000

590999.71700000

2978568.81000000

15.70007290

179211.09100000

435337.32200000

192.42284000

2187.55666000

8138.26280000

553.26383050

819.77264067

1450.35465300

17522.99100000

5370085.81000000

676688.40527000

676688.40527000
46113.13100000

1523776.38350366

1173722.58799000

223213.98300000

SAD

8670.51229542

663.30892594

1903.27075040

0.00000000
17163.74790000

22221.33600000

72553.70504600

10128.86100000

257475.74501430

146829.45991030

24607.99033000

SIU

0.00000000

1.67759355

0.00000000

0.00000000

0.00000000

0.00000000

0.00000000

0.00000000

8257.78465000

43553.61820000

98650.55490000

751310.17600000

787037.70700000

95185.31270000

118381.50570000

381727.70240000

0.00000000

22162.41170000

21057.58660000

194.30298000

500.22289890

482.60072850

263.64082708

10355.80323700

363.19158690

1274.92875100

177799.53390000

9018869.31567000

145374.00000000

479733.69724907

2057458.74041670

202665.91800000
2098.21509000

47601.1129000

123008.52488900

28065.70300000

309294.17418191

157119.61830000

24349.59365000

CIV

0.00000000

0.08889043

0.00000000

0.00000000

0.00000000

0.00000000

0.00000000

0.00000000

7243.15770000

331467.12200000

7023747.10000000

1043698.27000000

2885240.59000000

172587.46500000

2251046.04000000

3973383.19000000

0.00000000

79262.17080000

56279.75610000

106.34612000

544.33286000

212.79767000

222.47497230

249.27909842

443.14768800

552.33823770

10894866.80000000

249726.33456000

3484955.70000000

4338291.59692093

1629415.81196700

216540.35280000
10619.95465000 12514.82570000 122832.56114100 9882.41590000 896693.21764775 268857.69429500 36430.06330000

MAR

0.00000000

104.49285891

0.00000000

0.00000000

0.00000000

0.00000000

0.00000000

0.00000000

347.72210900

6542.29663000

288020.95600000

495320.01400000

83577.66150000

2558851.80000000

1827168.12000000

16672166.4700000

223.06021300

38197.19700000

374473.24500000

2393.89240000

7722.30620000

6606.69376000

3945.58658777

14026.37850610

4599.72359700

257134.65400000

1381128.30000000

2586581.49240000

429535.02000000

10829071.3387382

12359164.6399700

1260379.48600000 


$\begin{array}{lll}\text { ALG } & 0.00000000 & 0.00000000 \\ \text { MIL } & 0.00000000 & 0.00000000 \\ \text { BOV } & 69630.73592499 & 25590.77627501 \\ \text { LEI } & 131776.00034798 & 8411.42823202 \\ \text { AOU } & 1495570.05101426 & 1625353.64918574 \\ \text { EXT } & 28578.20351964 & 21008.12187036 \\ \text { SID } & 485246.96344133 & 75959.20595867 \\ \text { MAQ } & 502338.07645424 & 355160.89454576 \\ \text { MET } & 637191.44494743 & 325782.82205257 \\ \text { AUT } & 2763806.81085067 & 699699.24914933 \\ \text { MAD } & 3363112.49610568 & 2619414.74389432 \\ \text { QUI } & 1899493.85109007 & 2414149.52890993 \\ \text { ADU } & 726.96654072 & 190.03438528 \\ \text { OQU } & 208545.61154718 & 366880.66545282 \\ \text { TEX } & 1345866.63458224 & 370118.01241777 \\ \text { ICAF } & 420375.91235171 & 42960.69464829 \\ \text { BEN } & 569900.26835399 & 303308.51564601 \\ \text { ABT } & 1169295.02587746 & 407333.09112254 \\ \text { LAC } & 341581.67418916 & 494514.42081084 \\ \text { ACU } & 502865.14114169 & 25644.08265831 \\ \text { OLE } & 260021.63762875 & 7315.72445125 \\ \text { ALI } & 4862958.15515949 & 198092.06884051 \\ \text { DIV } & 3742794.86527949 & 1607938.66872051 \\ \text { SIU } & 3654469.95583938 & 4386654.79686062 \\ \text { CIV } & 3241337.51124374 & 946265.63875626 \\ \text { MAR } & 7573890.14791787 & 5874732.01187013 \\ \text { SER } & 52593579.57089790 & 20930451.02607210 \\ \text { SAD } & 2000332.15685453 & 2879013.75414547 \\ & & \end{array}$

TABLE DP (*, I )

$\begin{array}{ll} & \text { CAF } \\ \text { RO } & 1.000000 \\ \text { PWMO } & 1.000000 \\ \text { PWEO } & 1.000000 \\ \text { PEO } & 1.000000 \\ \text { PDO } & 1.000000 \\ \text { PO } & 1.000000 \\ \text { VSO } & 4354997.828051 \\ \text { VAO } & 2296637.853561 \\ \text { LDO } & 338817.755726 \\ \text { KO } & 1957820.097835 \\ \text { CMO } & 430206.909000 \\ \text { CGO } & 0.000000 \\ \text { INVO } & 0.000000 \\ \text { ESTO } & -952.762547 \\ \text { VQO } & 3992484.226123 \\ & \end{array}$

CAN

1.000000

1.000000

1.00000

1.000000

1.000000

4338716.969028

2311605.389007

761961.447957

1549643.941050

50064.099000

0.000000

0.000000

$-4465.858360$

4288871.947968
ARR

1.000000

1.000000

1.000000

1.000000

1.000000

1.000000

1984028.963361

1342376.274718

195376.651268

1146999.623450

39752.739000

0.000000

0.000000

362540.340000

2034190.067120
$\mathrm{SOJ}$

1.000000

1.000000

1.000000

1.000000

1.000000

1.000000

4003499.997500

1269834.007826

101835.496898

1167998.510928

0.000000

0.000000

0.000000

$-836241.978000$

3576995.489500
ALG

1.000000

1.000000

1.000000

1.000000

1.000000

1.000000

457845.999223

271481.894336

39816.553369

231665.340967

0.000000

0.000000

0.000000

0.000000

457878.305880 


\begin{tabular}{|c|c|c|c|c|c|}
\hline VDO & 3992311.219051 & 4288543.358728 & 1983932.901420 & 3394149.489500 & 457844.305880 \\
\hline VMO & 173.007072 & 328.589241 & 50257.165700 & 182846.000000 & 34.000000 \\
\hline VEO & 362686.609000 & 50173.610300 & 96.061941 & 609350.508000 & 1.693343 \\
\hline TXSO & 24867.178542 & 5976.250572 & 2786.477539 & 99531.944193 & 0.000000 \\
\hline TXMO & 16.870342 & 4.514701 & 1299.442700 & 11.000000 & 1.000000 \\
\hline TXEO & 0.000000 & 0.000000 & 0.000000 & 0.000000 & 0.000000 \\
\hline sigma_t & 0.900000 & 0.90000 & 0.900000 & 0.900000 & 0.900000 \\
\hline sigma_s & 0.900000 & 0.90000 & 1.400000 & 2.000000 & 2.000000 \\
\hline+ & MIL & $\mathrm{BOV}$ & LEI & AOU & EXT \\
\hline RO & 1.000000 & 1.000000 & 1.000000 & 1.000000 & 1.000000 \\
\hline PWMO & 1.000000 & 1.000000 & 1.000000 & 1.000000 & 1.000000 \\
\hline PWEO & 1.000000 & 1.000000 & 1.000000 & 1.000000 & 1.000000 \\
\hline $\mathrm{PEO}$ & 1.000000 & 1.000000 & 1.000000 & 1.000000 & 1.000000 \\
\hline PDO & 1.000000 & 1.000000 & 1.000000 & 1.000000 & 1.000000 \\
\hline PO & 1.000000 & 1.000000 & 1.000000 & 1.000000 & 1.000000 \\
\hline VSO & 3803359.009930 & 11375335.931456 & 8001573.169651 & 48152273.576391 & 10456620.712767 \\
\hline VAO & 2980878.461152 & 9110110.008265 & 3166144.825355 & 31950291.585086 & 4635823.018736 \\
\hline LDO & 410421.433289 & 323123.599415 & 717760.123823 & 3129807.309816 & 1409340.464142 \\
\hline KO & 2570457.027863 & 8786986.408851 & 2448384.701532 & 28820484.275270 & 3226482.554594 \\
\hline $\mathrm{CMO}$ & 83118.091300 & 687166.820000 & 3077722.740000 & 20673359.910000 & 78074.129000 \\
\hline CGO & 0.000000 & 0.000000 & 0.000000 & 0.000000 & 0.000000 \\
\hline INVO & 0.000000 & 0.000000 & 0.000000 & 3068752.118000 & 16373.108870 \\
\hline ESTO & 94034.226000 & 3410158.021000 & 39287.458500 & 426373.313100 & 105048.307000 \\
\hline VoO & 3942713.993460 & 11468631.924446 & 8090337.242194 & 49467203.334415 & 11986284.533767 \\
\hline VDO & 3799401.993460 & 11333154.575056 & 7999701.745194 & 47582232.124569 & 8151413.843767 \\
\hline VMO & 143312.000000 & 135477.349390 & 90635.497000 & 1884971.209846 & 3834870.690000 \\
\hline VEO & 3957.016470 & 42181.356400 & 1871.424457 & 570041.441823 & 2305206.870000 \\
\hline TXSO & 1381.721638 & 52222.731404 & 304417.832259 & 572344.747661 & 584211.680000 \\
\hline TXMO & 884.000000 & 288.439390 & 6555.589000 & 55915.471846 & 287941.290000 \\
\hline TXEO & 0.000000 & 0.000000 & 0.000000 & 0.000000 & 0.000000 \\
\hline sigma_t & 0.900000 & 0.9000000 & 0.900000 & 0.900000 & 1.300000 \\
\hline sigma_s & 2.000000 & 1.7000000 & 0.900000 & 1.700000 & 0.800000 \\
\hline+ & SID & MAQ & MET & AUT & MAD \\
\hline RO & 1.000000 & 1.000000 & 1.000000 & 1.000000 & 1.000000 \\
\hline PWMO & 1.000000 & 1.000000 & 1.000000 & 1.000000 & 1.000000 \\
\hline PWEO & 1.000000 & 1.000000 & 1.000000 & 1.000000 & 1.000000 \\
\hline PEO & 1.000000 & 1.000000 & 1.000000 & 1.000000 & 1.000000 \\
\hline PDO & 1.000000 & 1.000000 & 1.000000 & 1.000000 & 1.000000 \\
\hline PO & 1.000000 & 1.000000 & 1.000000 & 1.000000 & 1.000000 \\
\hline VSO & 54021706.762738 & 24140683.403239 & 31518749.237091 & 42822289.538240 & 34438805.534427 \\
\hline VAO & 13944951.760651 & 11445255.964530 & 9167350.966842 & 10761828.756098 & 10747027.490301 \\
\hline LDO & 5145384.010626 & 4217365.689010 & 2542087.105264 & 3753134.969264 & 5539422.275344 \\
\hline KO & 8799567.750025 & 7227890.275520 & 6625263.861578 & 7008693.786834 & 5207605.214957 \\
\hline $\mathrm{CMO}$ & 2226333.680000 & 944217.960000 & 14526719.200000 & 17785849.100000 & 8030253.300000 \\
\hline
\end{tabular}




\begin{tabular}{|c|c|c|c|c|c|}
\hline CGO & 0.000000 & 0.000000 & 0.000000 & 0.000000 & 0.000000 \\
\hline INVO & 931074.383000 & 14938225.500000 & 11386412.570000 & 11026353.600000 & 1622472.950000 \\
\hline ESTO & 842096.291000 & -641744.778000 & 832460.142000 & 652342.579000 & 139750.694000 \\
\hline VQO & 50222036.052738 & 28050678.369239 & 39521360.746091 & 47043777.188240 & 32623301.784427 \\
\hline VDO & 47450214.242738 & 22140800.389239 & 29470882.032091 & 38499696.788240 & 31212301.604427 \\
\hline VMO & 2771821.810000 & 5909877.980000 & 10050478.714000 & 8544080.400000 & 1411000.180000 \\
\hline VEO & 6571492.540000 & 1999882.594000 & 2047867.191000 & 4322593.240000 & 3226503.920000 \\
\hline TXSO & 5070829.500000 & 3096369.500000 & 5548483.200000 & 7046020.800000 & 4193384.000000 \\
\hline TXMO & 174485.710000 & 435124.280000 & 702886.470000 & 1676350.100000 & 45719.780000 \\
\hline TXEO & 0.000000 & 0.000000 & 0.000000 & 0.000000 & 0.000000 \\
\hline sigma_t & 0.800000 & 2.100000 & 2.100000 & 2.100000 & 1.300000 \\
\hline sigma_s & 2.000000 & 1.900000 & 2.700000 & 1.900000 & 1.600000 \\
\hline+ & QUI & $\mathrm{ADU}$ & OQU & TEX & ICAF \\
\hline RO & 1.000000 & 1.000000 & 1.000000 & 1.000000 & 1.000000 \\
\hline PWMO & 1.000000 & 1.000000 & 1.000000 & 1.000000 & 1.000000 \\
\hline PWEO & 1.000000 & 1.000000 & 1.000000 & 1.000000 & 1.000000 \\
\hline PEO & 1.000000 & 1.000000 & 1.000000 & 1.000000 & 1.000000 \\
\hline PDO & 1.000000 & 1.000000 & 1.000000 & 1.000000 & 1.000000 \\
\hline $\mathrm{PO}$ & 1.000000 & 1.000000 & 1.000000 & 1.000000 & 1.000000 \\
\hline VSO & 80286757.426692 & 4095081.424823 & 6765639.455667 & 35162904.272122 & 5714960.973841 \\
\hline VAO & 28174350.277660 & 1500143.210380 & 1370307.087470 & 9226398.997197 & 1256977.877958 \\
\hline LDO & 5303343.270623 & 626320.991369 & 572113.452157 & 5165939.181352 & 279752.172000 \\
\hline KO & 22871007.007036 & 873822.219011 & 798193.635313 & 4060459.815845 & 977225.705958 \\
\hline $\mathrm{CMO}$ & 17660398.600000 & 12568.036500 & 799960.690000 & 17961311.300000 & 2110777.220000 \\
\hline CGO & 0.000000 & 0.000000 & 0.000000 & 0.000000 & 0.000000 \\
\hline INVO & 92220.877900 & 0.000000 & 2.193171 & 28063.569700 & 0.000000 \\
\hline ESTO & 2765286.070000 & -69479.663000 & 207837.581000 & 580269.954000 & -4138.490170 \\
\hline VQO & 87574002.371750 & 4824292.361864 & 6939902.803945 & 34942831.738122 & 3970997.720581 \\
\hline VDO & 77178075.227692 & 4059808.552923 & 6273447.486945 & 32069926.998122 & 3968645.793841 \\
\hline VMO & 10395927.144058 & 764483.808942 & 666455.317000 & 2872904.740000 & 2351.926740 \\
\hline VEO & 3108682.254000 & 35272.871900 & 492191.964000 & 3092977.276000 & 1746315.180000 \\
\hline TXSO & 9297915.599985 & 134462.315015 & 689490.200000 & 5064645.900000 & 475545.040000 \\
\hline TXMO & 644171.190114 & 8517.772886 & 51647.357000 & 293341.640000 & 150.989740 \\
\hline TXEO & 0.000000 & 0.000000 & 0.000000 & 0.000000 & 0.000000 \\
\hline sigma_t & 2.100000 & 0.800000 & 2.100000 & 1.900000 & 0.900000 \\
\hline sigma_s & 1.400000 & 2.000000 & 2.000000 & 1.810000 & 1.400000 \\
\hline+ & BEN & $\mathrm{ABT}$ & LAC & $\mathrm{ACU}$ & OLE \\
\hline RO & 1.000000 & 1.000000 & 1.000000 & 1.000000 & 1.000000 \\
\hline PWMO & 1.000000 & 1.000000 & 1.000000 & 1.000000 & 1.000000 \\
\hline PWEO & 1.000000 & 1.000000 & 1.000000 & 1.000000 & 1.000000 \\
\hline $\mathrm{PEO}$ & 1.000000 & 1.000000 & 1.000000 & 1.000000 & 1.000000 \\
\hline PDO & 1.000000 & 1.000000 & 1.000000 & 1.000000 & 1.000000 \\
\hline PO & 1.000000 & 1.000000 & 1.000000 & 1.000000 & 1.000000 \\
\hline VSO & 21179024.609646 & 18331834.694121 & 8500403.214288 & 5613932.902346 & 11278092.717574 \\
\hline VAO & 3577840.380372 & 2740344.646581 & 1271557.177179 & 866970.198410 & 1318694.418452 \\
\hline
\end{tabular}




\begin{tabular}{|c|c|c|c|c|c|}
\hline LDO & 1175468.133321 & 985852.244953 & 327793.380942 & 459994.817870 & 247154.365482 \\
\hline KO & 2402372.247051 & 1754492.401628 & 943763.796237 & 406975.380540 & 1071540.052970 \\
\hline CMO & 14418529.100000 & 12836876.600000 & 6337566.600000 & 1476534.950000 & 3278543.920000 \\
\hline CGO & 0.000000 & 0.000000 & 0.000000 & 0.000000 & 0.000000 \\
\hline INVO & 4451.208630 & 13567.940390 & 0.000000 & 0.000000 & 0.000000 \\
\hline ESTO & 156716.661000 & 539748.911000 & 108953.591200 & -143686.659500 & 121792.835000 \\
\hline VQO & 19586794.933146 & 17525288.629521 & 9065875.591258 & 4014478.934616 & 8824352.661974 \\
\hline VDO & 18906457.480146 & 17281088.138121 & 8487577.227258 & 4001141.912346 & 8477627.737574 \\
\hline VMO & 680337.453000 & 244200.491400 & 578298.364000 & 13337.022270 & 346724.924400 \\
\hline VEO & 2272567.125000 & 1050746.551000 & 12825.987030 & 1612790.990000 & 2800464.980000 \\
\hline TXSO & 4390204.200000 & 2532754.000000 & 1264397.000000 & 711740.650000 & 842927.310000 \\
\hline TXMO & 27024.813000 & 3875.141400 & 64784.254000 & 226.581270 & 7534.284400 \\
\hline TXEO & 0.000000 & 0.000000 & 0.000000 & 0.000000 & 0.000000 \\
\hline sigma_t & 0.900000 & 0.900000 & 0.900000 & 0.900000 & 0.800000 \\
\hline sigma_s & 1.400000 & 1.400000 & 1.400000 & 1.400000 & 1.800000 \\
\hline+ & ALI & DIV & SIU & CIV & MAR \\
\hline RO & 1.000000 & 1.000000 & 1.000000 & 1.000000 & 1.000000 \\
\hline PWMO & 1.000000 & 1.000000 & 1.000000 & 1.000000 & 1.000000 \\
\hline PWEO & 1.000000 & 1.000000 & 1.000000 & 1.000000 & 1.000000 \\
\hline PEO & 1.000000 & 1.000000 & 1.000000 & 1.000000 & 1.000000 \\
\hline PDO & 1.000000 & 1.000000 & 1.000000 & 1.000000 & 1.000000 \\
\hline PO & 1.000000 & 1.000000 & 1.000000 & 1.000000 & 1.000000 \\
\hline VSO & 29368474.772564 & 35115596.877058 & 43253807.696062 & 91646620.450893 & 123227499.653928 \\
\hline VAO & 6086589.949124 & 11182608.314893 & 22497933.062373 & 49812723.077508 & 66648336.906458 \\
\hline LDO & 2471325.016838 & 3420740.474873 & 10587772.416671 & 10344978.555209 & 44172900.577424 \\
\hline KO & 3615264.932285 & 7761867.840020 & 11910160.645702 & 39467744.522299 & 22475436.329034 \\
\hline CMO & 19137943.800000 & 5239576.800000 & 15880119.569000 & 0.000000 & 61218095.118200 \\
\hline CGO & 0.000000 & 0.000000 & 0.000000 & 0.000000 & 0.000000 \\
\hline INVO & 4451.208630 & 1148130.836000 & 56276.182900 & 82652508.000000 & 3928290.555448 \\
\hline ESTO & 293146.857000 & 513703.202000 & 3883.553420 & 0.000000 & 755189.533327 \\
\hline $\mathrm{VQO}$ & 29681415.535064 & 36596625.004058 & 44215074.069602 & 91646624.835144 & 120334948.859911 \\
\hline VDO & 28419531.266064 & 33483404.824058 & 43193654.929702 & 91646530.088259 & 117153817.901911 \\
\hline VMO & 1261884.269000 & 3113220.180000 & 1021419.139900 & 94.746885 & 3181130.958000 \\
\hline VEO & 948943.502000 & 1632192.013000 & 60152.766760 & 90.362634 & 6073681.753017 \\
\hline TXSO & 6363402.800000 & 8047231.500000 & 6333212.700000 & 3193815.110000 & 5091880.200000 \\
\hline TXMO & 88877.169000 & 252543.180000 & 6405.739900 & 0.000000 & 19043.758000 \\
\hline TXEO & 0.000000 & 0.000000 & 0.000000 & 0.000000 & 0.000000 \\
\hline sigma_t & 0.900000 & 1.900000 & 0.900000 & 0.900000 & 1.300000 \\
\hline sigma_s & 1.800000 & 2.600000 & 1.100000 & 0.900000 & 1.100000 \\
\hline+ & SER & SAD & & & \\
\hline RO & 1.000000 & 1.000000 & & & \\
\hline PWMO & 1.000000 & 1.000000 & & & \\
\hline PWEO & 1.000000 & 1.000000 & & & \\
\hline PEO & 1.000000 & 1.000000 & & & \\
\hline
\end{tabular}




$\begin{array}{lll}\text { PDO } & 1.000000 & 1.000000 \\ \text { PO } & 1.000000 & 1.000000 \\ \text { VSO } & 239121297.138160 & 139218562.871291 \\ \text { VAO } & 130454780.148554 & 92195382.152387 \\ \text { LDO } & 75256326.952862 & 92195382.152387 \\ \text { KO } & 55198453.195692 & 0.000000 \\ \text { CMO } & 137721702.872000 & 2186263.740000 \\ \text { CGO } & 0.000000 & 126652130.000000 \\ \text { INVO } & 1414928.928740 & 420876.089900 \\ \text { ESTO } & 2520.874030 & 21312.147700 \\ \text { VQO } & 242295516.925460 & 139218562.871291 \\ \text { VDO } & 236887115.969960 & 139218562.871291 \\ \text { VMO } & 5408400.955500 & 0.000000 \\ \text { VEO } & 2234181.112000 & 0.000000 \\ \text { TXSO } & 14695570.870000 & 0.000000 \\ \text { TXMO } & 5495.611823 & 0.000000 \\ \text { TXEO } & 0.000000 & 0.000000 \\ \text { Sigma_t } & 1.300000 & \end{array}$

sigma t 1.300000

sigma_s 1.100000$$
\text { ; }
$$

SCALAR

WO / $1.00000000 /$

YMO / 453999093.97771800 /

YEO / 131682361.54893700 /

REIO / 131682361.54893700 /

DIVO / 32920590.38723430 /

TXYO / 19627300.00000000 /

TXKO / 9341600.00000000 /

TGEO / 0.00000000 /

TRGO / 0.00000000 /

TRMO / 7177329.00000000 /

TERO / 14006422.00000000

EO / 1.00000000 /

VARIÁVEIS extraídas do tablo $\mathrm{RO}(\mathrm{N})=\mathrm{DP}($ "RO", N $)$;

$\mathrm{KO}(\mathrm{N}) \quad=\mathrm{DP}(" \mathrm{KO} ", \mathrm{~N})$

$\mathrm{VAO}(\mathrm{N})$

$\mathrm{CMO}(\mathrm{I})$

INVO (I)

$=\mathrm{DP}($ "INVO", I $)$

$\operatorname{ESTO}(\mathrm{I})$

$\operatorname{TXMO}(I)$

$=\mathrm{DP}($ "TXMO", I)

TXEO (I)

sigma_s (I)

$\operatorname{VDO}(\mathrm{I})$

= DP $($ "sigma_s", I

DP ("VDO", I )

$\mathrm{VSO}(\mathrm{I})$

PO(I)

$=\mathrm{DP}($ "PO", I);

VMO (I)

PEO (I)

$=\mathrm{DP}($ "PEO", I $)$;
$=\mathrm{DP}($ "VAO", N);

$=\mathrm{DP}(" \mathrm{CMO} ", \mathrm{I})$;

$=\mathrm{DP}(" \mathrm{ESTO} ", \mathrm{I})$

$=$ DP ("VSO"

$=$ DP ("VSO", I);

$=$ DP ("VMO", I);

$=\mathrm{DP}($ "PWMO", I)

$=\mathrm{DP}(" \mathrm{PDO} ", \mathrm{~N})$;
LDO (I)

$\mathrm{CGO}(\mathrm{I})$

$\operatorname{TXSO}(I)$

sigma_t (I)

$\mathrm{VQO}(\mathrm{I})$

PWEO (I)
$=\mathrm{DP}($ "LDO", I );

$=\mathrm{DP}($ "CGO", I);

$=\mathrm{DP}($ "TXSO", I $)$;

= DP ("sigma_t $t$ ", I );

$=\mathrm{DP}($ "VQO", I );

$=\mathrm{DP}(" \mathrm{NEO}, \mathrm{I})$; 
*DECOMPOSIÇÃO DAS VARIÁVEIS EM PREÇOS E VALORES EM VOLUME

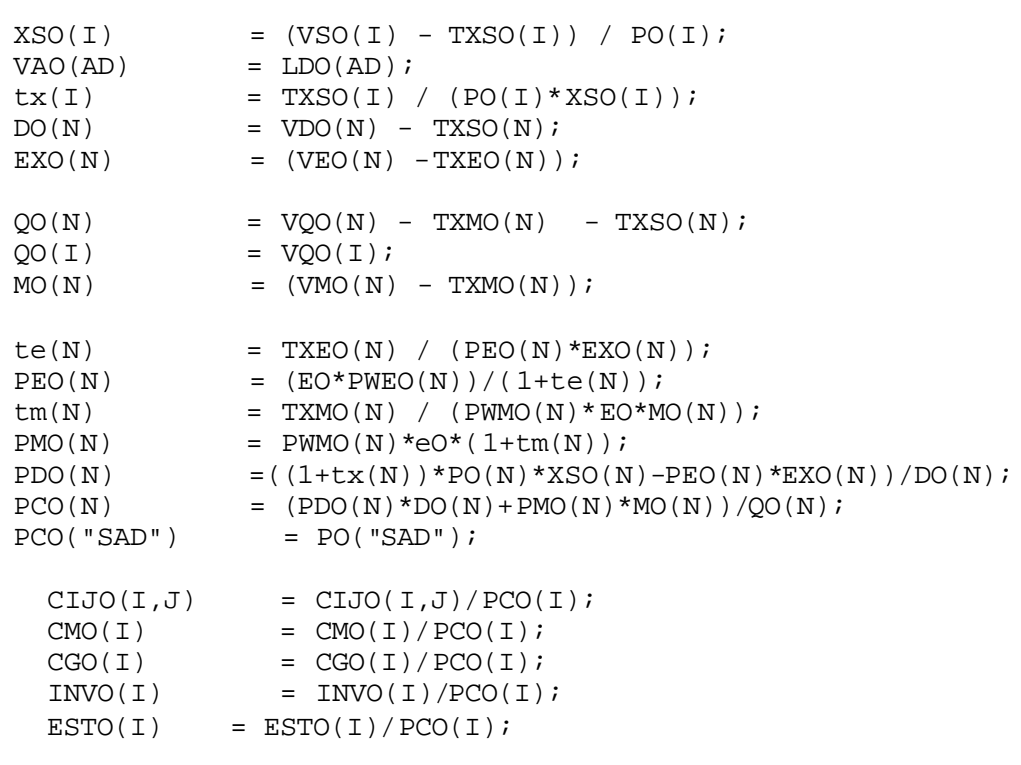

*CÁLCULO DAS OUTRAS VARIÁVEIS
$\mathrm{LSO} \quad=\operatorname{SUM}(I, \operatorname{LDO}(\mathrm{I}))$
$\mathrm{CTMO} \quad=\mathrm{SUM}\left(\mathrm{I}, \mathrm{PCO}(\mathrm{I}){ }^{*} \mathrm{CMO}(\mathrm{I})\right)$
CTGO $=\operatorname{SUM}(I, P C O(I) * C G O(I))$
$\mathrm{CO}(\mathrm{I}) \quad=\mathrm{CMO}(\mathrm{I})+\mathrm{CGO}(\mathrm{I})$
ITO $\quad=\operatorname{SUM}(I, P C O(I) * \operatorname{INVO}(I)) ;$
$\quad=\operatorname{SUM}(I, P C O(I) * \operatorname{ESTO}(I)) ;$
$\operatorname{DIO}(I)=\operatorname{SUM}(J, C I J O(I, J))$
$\operatorname{CIO}(\mathrm{J}) \quad=\operatorname{SUM}(I, \operatorname{CIJO}(\mathrm{I}, \mathrm{J})) ;$
$\operatorname{PVAO}(\mathrm{N}) \quad=\left(\mathrm{PO}(\mathrm{N}) * \mathrm{XSO}(\mathrm{N})-\mathrm{SUM}\left(\mathrm{J}, \mathrm{PCO}(\mathrm{J}){ }^{*} \mathrm{CIJO}(\mathrm{J}, \mathrm{N})\right)\right) / \mathrm{VAO}(\mathrm{N})$;
YDMO $\quad=$ YMO-TXYO;
SMO $\quad=$ YDMO-CTMO

*CÁLCULO DOS PARÂMETROS

pms $\quad=$ SMO $/$ YDMO;

lambda $\quad=\operatorname{REIO} /(\operatorname{SUM}(\mathrm{N}, \mathrm{RO}(\mathrm{N}) * \mathrm{KO}(\mathrm{N})))$; 


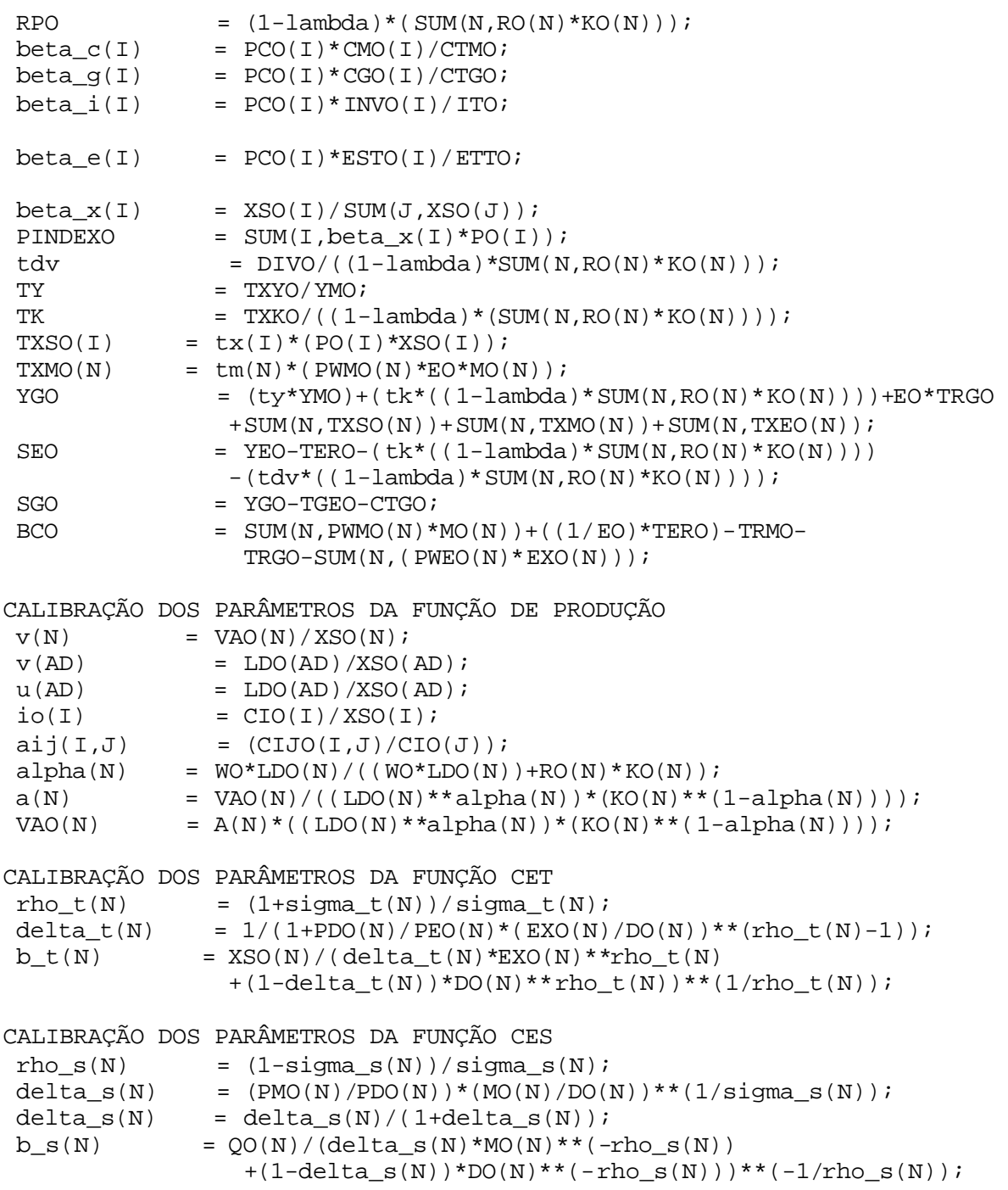




\section{REFERÊNCIAS BIBLIOGRÁFICAS}

ALMEIDA, C.O.; BACHA, C.J.C. Determinantes da balança comercial de produtos agrícolas e agroindustriais do Brasil: 1961/95. Pesquisa e Planejamento Econômico, v.28, n.1, p.95-128, abr. 1998.

BAER, W. A economia brasileira. São Paulo: Livraria Nobel, 1996. 416p.

BALE, M.D.; LUTZ, E. Price distortions in agriculture and their effects: an international comparison. American Journal of Agriculture Economics, v.63, n.1, p.8-22, Feb.1981.

BANCO CENTRAL DO BRASIL. Tabelas estatísticas da balança comercial. http://bacen.gov.br (10 Set. 2001)

BAUTISTA, R.M.; ROBINSON, S.; TARP, F.; WOBST, P. Policy bias and agriculture: partial and general equilibrium measures. Washington: International Food Policy Research Institute, Trade and Macroeconomics Division, 1998. 35p. (TMD Discussion Paper, 25)

BLAUG, M. A metodologia da economia. 2.ed. São Paulo: EDUSP, 1999. 385p.

BRASIL. Ministério do Desenvolvimento, Indústria e Comércio Exterior - Secretaria de Comércio Exterior. Evolução do comércio exterior brasileiro 1950 a 2001. http://www.mdic.gov.br/indicadores (5 Out. 2001) 
BRASIL. Ministério da Agricultura, Pecuária e Abastecimento. Companhia Brasileira de Abastecimento. Índices de preços pagos e recebidos. http://www.agricultura.gov.br (20 Ago. 2001)

BRASIL. Ministério da Agricultura, Pecuária e Abastecimento. Tabelas estatísticas da agropecuária. http://www.agricultura.gov.br (20 Ago. 2001)

BRASIL. Secretaria da Receita Federal. Tabelas da arrecadação. http://www.receita.fazenda.gov.br (15 Set. 2001)

BROOKE, A.; KENDRICK, D.; MEERAUS, A. GAMS - a user's guide, Release 2.25. Washington: GAMS Development Corporation, 1996. 286p.

BURNQUIST, H. L. A proteção nominal da agricultura e o regime cambial - 1972/94. Pesquisa e Planejamento Econômico, v.27, n.2, p.433-458, ago. 1997.

BYERLEE, D; SAIN, G. Food pricing policy in developing countries: bias against agriculture or for urban consumers? American Journal of Agriculture Economics, v.68, n.4, p.961-969, Nov. 1986.

CAPROS, P.; KARADELOGLOU, P.; MENTZAS, G. An empirical assessment of macroeconometric and CGE approaches in policy modeling. Journal of Policy Modeling, v.12, n.3, p.557-585, 1990.

CARVALHO, A.; DE NEGRI, J.A. Estimação de equações de importação e exportação de produtos agropecuários para o Brasil (1977/1998). Rio de Janeiro: IPEA, 2000. 30p. (Texto para a Discussão, 698)

CARVALHO, A.; PARENTE, M.A. Estimação de equações de demanda de importações por categoria de uso para o Brasil (1978/1996). Rio de Janeiro: IPEA, 1999. 31p. (Texto para a Discussão, 636) 
CASTRO, A.S.; CAVALCANTI, M.A.F.H. Estimação de equações de exportação e importação para o Brasil - 1955/95. Rio de Janeiro: IPEA, 1997. 53p. (Texto para a Discussão, 469)

CASTRO, A.S.; ROSSI JÚNIOR, J.L. Modelos de previsão para a exportação das principais commodities brasileiras. Rio de Janeiro: IPEA, 2000. 35p. (Texto para a Discussão, 716)

CAVALCANTI, M.A.F.H.; RIBEIRO, F.J. As exportações brasileiras no período de 1977/96: desempenho e determinantes. Rio de Janeiro: IPEA, 1998. 46p. (Texto para a Discussão, 545)

CHAMBERS, G.H.; JUST, R.E. Effects of exchange rate changes on U.S. agriculture: a dynamic analysis. American Journal of Agricultural Economics, v.63, n.1, p.3446, Feb. 1981.

DECALUWÉ, B.; MARTENS, A. CGE modeling and developing economies: a concise empirical survey of 73 applications to 26 countries. Journal of Policy Modeling, v.10, n.4, p.529-568, 1988.

DECAluWÉ, B.; MARTIN, M.C.; SOUISSI, M. Modele Réel D'une Économie ouverte avec gouvernement. Québec: CRÉFA, Université Laval, 1996. 42p.

DECALUWÉ, B.; PATRY, A; SAVARD, L.; THORBECKE, E. Poverty analysis within general equilibrium framework. Quebec: CRÉFA, Université Laval, 1999a. 58p.

DECALUWÉ, B.; DISSOU, Y.; ROBICHAUD, V. Regionalization and labor market rigidities in developing countries: a CGE analysis of UEMOA. Quebec: CRÉFA, Université Laval, 1999b. 29p.

DERVIS, K.; MELO, J.; ROBINSON, S. General equilibrium models for development policy. Washington: Camnridge University Press, 1982. 526p. 
DEVARAJAN, S.; LEWIS, J.D.; ROBINSON, S. Policy lessons from trade-focused, two-sector models. Journal of Policy Modeling, v.12, n.4, p.625-657, 1990.

DORNBUSCH, R. Exchange rates and prices. The American Economic Review, v.77, n.1, p.93-106, Mar. 1997.

FERREIRA, FILHO, J.B.S. MEGABRÁS - Um modelo de equilíbrio geral computável aplicado à análise da agricultura brasileira. São Paulo, 1995. 159p. Tese (Doutorado)

- Faculdade de Economia, Administração e Contabilidade, Universidade de São Paulo.

FERREIRA FILHO, J.B.S. Ajuste estrutural e agricultura na década de 80: uma abordagem de equilíbrio geral. Pesquisa e Planejamento Econômico, v.27, n.2, p.397-432, ago. 1997.

FERREIRA FILHO, J.B.S. Impact of reforms on input markets in Brazil. /Apresentado ao Economic policy reforms and agricultural input markets: experiences, lessons and challenges, South Africa, 2000/

FUNDAÇÃO INSTITUTO BRASILEIRO DE GEOGRAFIA E ESTATÍSTICA. Contas Nacionais. Rio de Janeiro: IBGE, 1995a.

FUNDAÇÃO INSTITUTO BRASILEIRO DE GEOGRAFIA E ESTATÍSTICA. Matriz de Insumo-produto. Rio de Janeiro: IBGE, $1995 \mathrm{~b}$.

FUNDAÇÃO INSTITUTO BRASILEIRO DE GEOGRAFIA E ESTATÍSTICA. Pesquisa Industrial Anual - PIA. Rio de Janeiro: IBGE, 1995c.

FUNDAÇÃO INSTITUTO BRASILEIRO DE GEOGRAFIA E ESTATÍSTICA. Censo Agropecuário 1995/1996. Rio de Janeiro: IBGE, 1997.

FUNDAÇÃO INSTITUTO BRASILEIRO DE GEOGRAFIA E ESTATÍSTICA. Classificação Nacional de Atividades Econômicas. Rio de Janeiro: IBGE, 2000. 
GASQUES, J.G.; CONCEIÇÃO, J.C.P.R. Transformações estruturais da agricultura e produtividade total dos fatores. Rio de Janeiro: IPEA, 2000. 60p. (Textos para Discussão, 768)

GONÇALVES, R.H.P. Funções de exportação para o complexo agroindustrial brasileiro 1970-1997. Viçosa, 1997. 92p. Dissertação (Mestrado) - Universidade Federal de Viçosa.

GUILHOTO, J.J.M. Um modelo computável de equilíbrio geral para planejamento e análise de políticas agrícolas (PAPA) na economia brasileira. Piracicaba, 1995. 258p. Tese (Livre-Docência) - Escola Superior de Agricultura "Luiz de Queiroz", Universidade de São Paulo.

GÜZEL, H.A.; KULSHRESHTHA, S.N. Effects of real exchange rate changes on Canadian agriculture: a general equilibrium evalution. Journal of Policy Modeling, v.17, n.6, p.639-657, 1995.

HARRISON, G.W.; JONES, R.; KIMBELL, L.J.; WIGLE, R. How robust is applied general equilibrium analysis? Journal of Policy Modeling, v.15, n.1, p.99-115, 1993.

HELFAND, S.M. The political economy of agricultural policy in Brazil: decision making and influence from 1964 to 1992. Latin American Research Review, v.34, n.2, p.3-40, 1999.

HELFAND, S.M.; REZENDE, G.C. Brazilian agriculture in the 1990s: impact of the policy reforms. Rio de Janeiro: IPEA, 2001. 39p. (Texto para a Discussão, 785)

HORRIDGE, J.M.; PARMENTER, B.R. ; PEARSON, K.R. ORANI-G: A general equilibrium model of the Australian Economy. Australia: Monash University, 1998. 70p. 
HORTA, M. H. ; SOUZA, C. F. B. A inserção das exportações brasileiras: análise setorial no período 1980/96. Rio de Janeiro: IPEA, 2000. 34p. (Texto para a Discussão, 736)

INSTITUTO DE PESQUISA ECONÔMICA APLICADA. IPEADATA: índice da taxa de câmbio real efetiva. http://www.ipea.gov.br/ (10 Out. 2001)

KILKENNY, M.; ROBINSON, S. Computable general equilibrium analysis of agricultural liberalization: factor mobility and macro closure. Journal of Policy Modeling, v.12, n.3, p.527-556, 1990.

LAMOUNIER, B. (Coord.) Determinantes políticos da política agrícola: um estudo de atores, demandas e mecanismos de decisão. Brasília: IPEA, 1994. 26p. (Estudos de Política Agrícola, 9)

LÖFGREN, H.; HARRIS, R.L.; ROBINSON, S. A standard computable equilibrium (CGE) model in GAMS. Washington: International Food Policy Research Institute, Trade and Macroeconomics Division, 2001. 80p. (TMD Discussion Paper, 75)

MAMINGI, N. How prices and macroeconomic policies affect agricultural supply and the environment. Washington: World Bank, Environment, Infrastructure, and Agriculture Division Policy Research Department, 1996. 88p.

MARTNER, R. Efeitos macroeconômicos de uma desvalorização cambial: análise de simulação para o Brasil. Pesquisa e Planejamento Econômico, v.22, n.1, p.35-72, abr. 1992.

MELO, J. Computable general equilibrium models for trade policy analysis in developing countries: a survey. Journal of Policy Modeling, v.10, n.4, p.469-503, 1988.

MELO, J.; ROBINSON, S. Product differentiation and the treatment of foreign trade in Computable General Equilibrium models of small economies. Journal of International Economics, v.27, n.1, p.47-67, 1989. 
MILLER, R.E.; BLAIR, P.D. Input-output analysis: foundations and extensions. Englewood Cliffs: Prentice-Hall, 1985. 464p.

MOSS, J.E.; McERLEAN, S.A.; WU, Z.; DOHERTY, A.; IJPELAAR, J. Export dependence, exchange rate movements and agricultural incomes. Belfast: Queen's University Belfast, Agricultural and Food Economics, 2001. 29p.

NAJBERG, S.; RIGOLON, F.J.Z.; VIEIRA, S. Modelo de equilíbrio geral computável como instrumento de política econômica: uma análise de câmbio $\mathrm{x}$ tarifas. Rio de Janeiro: BNDES, Departamento Econômico - DEPEC, 1995. 24p. (Textos para Discussão, 30)

OLIVEIRA JÚNIOR, M. A liberalização comercial brasileira e os coeficientes de importação - 1990/95. Rio de Janeiro: IPEA, 2000. 23p. (Texto para a Discussão, 703)

PERRONI, C.; RUTHERFORD, T.F. A comparison of the performance of flexible functional forms for use in applied general equilibrium analysis. Washington: GAMS General Equilibrium Research Fund, 1996. 10p.

RODRIGUES, R.L.; GUILHOTO, J.J.M. Uma análise dos impactos da abertura comercial sobre a estrutura produtiva da economia brasileira: 1990 a 1995. In: MONTOYA, M.A. (Org.) Relações intersetoriais do Mercosul e da economia brasileira. Passo Fundo: EDIUPF, 1998. cap. 4, p.131-150.

SCHIFF, M.; VALDÉS, A. Agriculture and the macroeconomy. In: GARDNER, B.; RAUSSER, G. (Org.) HandBook of agriculture economics. Washington: Elsevier Science, 1998. cap.1, p.1-35.

SCHUH, G. E. The exchange rate and United States Agricultural American Journal of Agricultural Economics, v.67, n.1, p.1-13, 1974. 
SCHUH, G. E. Agricultura e energia no Brasil: a substituição de importação reexaminada. In: ARAÚJO, P. F. C. ; SCHUH, G. E. (Coord.) Desenvolvimento da agricultura: estudos de casos. São Paulo: Pioneira, 1983. cap.5, p.345-358.

SCHUH, G. E. The transformation of Brazilian agriculture: implications for research. /Apresentado ao Seminário de Economia Agrícola - Empresa Brasileira de Pesquisa Agropecuária (EMBRAPA), Brasilia, abr. 1998 /

SCHULTZ, T. W. On economics and politics of agriculture : distortion of agriculture incentives. Bloomington: Indiana University Press, 1978.

SINDICATO NACIONAL DAS INDÚSTRIAS PARA DEFESA AGRÍCOLA. Evolução das vendas de defensivos em valor por categoria. http://www.sindag.com.br/ (15 Ago. 2001)

TAYLOR, D. S. ; PHILLIPS, T.P. Food-pricing policy in developing countries: further evidence on cereal producer prices. American Journal of Agricultural Economics, v.71, n.4, p.1036-1043, Nov. 1991.

THISSEN, M. A classification of empirical CGE modelling. Groningen: University of Groningen, 1998a. 19p. (SOM Research report, 99C01)

THISSEN, M. Two decades of CGE modelling lessons from models for Egypt. Groningen: University of Groningen, Dec. 1998b. 19p. (SOM Research report, 99C02)

WEST, G.; JENSEN, R. Regional economic modelling: some issues of use and validation. /Apresentado ao 15. PRSCO Meeting, Weelington, Nova Zelândia, Dec. $1997 /$ 